


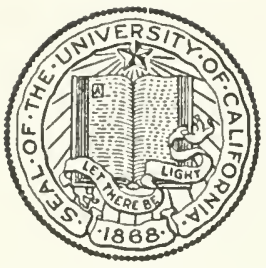

THE LIBRARY

OF

THE UNIVERSITY OF CALIFORNIA LOS ANGELES 



WANDERINGS IN SOUTH AMERICA 




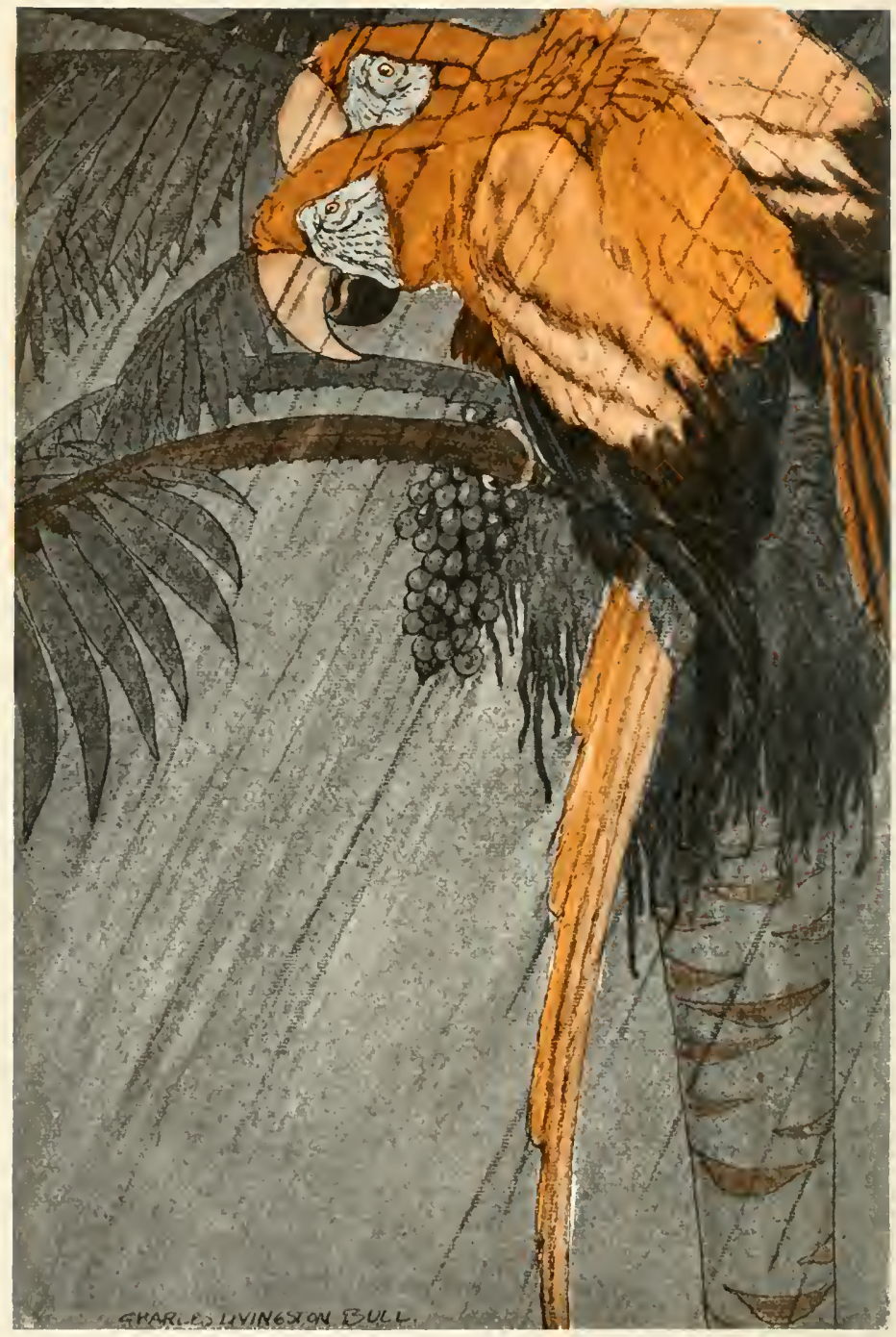

"The Empreror of all the Parrots", 


\section{WANDERINGS IN SOUTH AMERICA}

THE NOR'TH-WEST OF THE UNITED STATES AND THE ANTILLES,

IN THE YEARS 1812, 1816, 1820, \& 1824

With Original Instructions for the perfect preservation of Birds, etc. for Cabinets of Natural History

\section{BY \\ CHARLES ${ }_{L_{11}}^{\text {W ATERTON }}$}

Including a Memoir of the Author

BY

NORMAN MOORE, M.D.

With Illustrations and a Brief Introduction

BY

CHARLES LIVINGSTON BULL

NEW YORK

STURGIS \& WALTON

COMPANY

1909 


\section{Copyright 1909 \\ BY STURGIS \& WALTON COMPANY}

Set up and Electrotyped. Published June, 1909

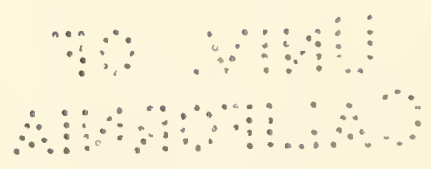


2371

$M / 31$

1909

WANDERINGS IN SOUTH AMERICA 



\section{PREFACE TO THE FIRST EDITION}

I offer this book of Wanderings with a hesitating hand. It has little merit, and must make its way through the world as well as it can. It will receive many a jostle as it goes along, and perhaps is destined to add one more to the number of slain, in the field of modern criticism. But if it fall, it may still, in death, be useful to me; for, should some accidental rover take it up, and, in turning over its pages, imbibe the idea of going out to explore Guiana, in order to give the world an enlarged description of that noble country, I shall say, "fortem ad fortia misi," and demand the armour; that is, I shall lay claim to a certain portion of the honours he will receive, upon the plea, that I was the first mover of his discoveries; for, as Ulysses sent Achilles to Troy, so I sent him to Guiana. I intended to have written much more at length; but days, and months, and years, have passed away, and nothing has been done. Thinking it very probable that I shall never have patience enough to sit down and write a full account of all I saw and examined in those remote wilds, I give up the intention of doing so, and send forth this account of my $W$ anderings, just as it was written at the time.

If critics are displeased with it in its present form, I beg to observe that it is not totally devoid of interest, and that it contains something useful. Several of the unfortunate gentlemen who went 
out to explore the Congo, were thankful for the instructions they found in it; and Sir Joseph Banks, on sending back the journal, said in his letter, "I return your journal, with abundant thanks for the very instructive lesson you have favoured us with this morning, which far excelled, in real utility, everything I have hitherto seen." And in another letter he says, "I hear with particular pleasure your intention of resuming your interesting travels, to which natural history has already been so much indebted." And again, "I am sorry you did not deposit some part of your last harvest of birds in the British Museum, that your name might become familiar to naturalists, and that your unrivalled skill in preserving birds be made known to the public." And again, "You certainly have talents to set forth a book, which will improve and extend materially the bounds of natural science."

Sir Joseph never read the third adventure. Whilst I was engaged in it, death robbed England of one of her most valuable subjects, and deprived the Royal Society of its brightest ornament. 


\section{CON'TEN'TS}

Preface to First Edition.................... ix

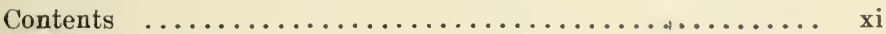

List of Illustrations..................... xvii

Introduction $\ldots \ldots \ldots \ldots \ldots \ldots \ldots \ldots \ldots \ldots \ldots \ldots \ldots \ldots \ldots \ldots$

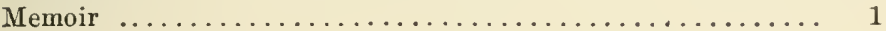

\section{FIRST JOURNEY}

\section{CHAPTER I}

Object of the Wanderings-Demerara R.-Saba-ToueanForest Trees-Parasites-Bush-rope-Red Monkey-Wild animals-Sloths-Venomous snakes-Lizards-Bell-birdHoutou-Insects-Dog poisoned with Wourali-Falls-Essequibo R.-Rapid decay-Falls of the Essequibo-Macoushia-A white recluse-The Watermamma-A savage financier-The Jabiru-Ants' nests-Fort St. Joachim-Lake Parima ........................... 29-73

\section{CHAPTER II}

The Macoushi Indians-Poison vendors-apparent failure of poison-Collecting materials for wourali-poison-Preparing the poison-Superstitions-The blow-pipe gun-The Ourah-The Samourah-Silk-grass-Acuero fruit-Coucourite palm-Wild cotton-Arrows-Quivers-Jaw of Pirai-Packing the arrows-Cotton basket-Gun sight made of Acouri teeth-Poisoned fowl-Suspending the guns-The bow-Ingenious arrows-Small quivers-A wild hog shot-Utilization of indigenous products ....... 74-89 


\section{CHAPTER III}

Operation of the Wourali-Its effects on the Ai, or Threetoed Sloth-Death rescmbling sleep-A poisoned OxPoison proportionate to size of animal-Alleged antidotes An Indian killed by his own arrow-Ligatures and the knife-Descent of the Essequibo-Skill of the boatmanThe Buccaneers-Tertian ague-Experiments with Wourali-Value of a ligaturo-Artificial respiration-Long life and quiet death of Wouralia-When good King Arthur ruled this land-Return of health............. 90-98

REMARKS 99-105

\section{SECOND JOURNEY}

\section{CHAPTER I}

From Liverpool to Pernambuco-Stormy petrels-Tropical zoölogy-Flying fish-Bonito, Albicore, and "Dolphin", -Frigate bird-Arrival at Pernambuco-The expelled Jesuit-Pombal, the Captain-General-Southey's history of Brazil-Botanical garden-Sangre do Buey-Rattlesnake Narrow escape-Rainy-Sail for Cayenne-Shark-catching

\section{CHAPTER II}

Arrival at Cayenne-Flamingos-Curlews, \&c.-Vegetable productions of Cayenne-La Gabrielle-Cock of the RockGrand Gobe-mouche-Surinam-The Coryntin-New Amsterdam-Stabroek, now George-town-Produce of Demerara-Slavery-A traveler's necessaries-Walking barefoot-The best costumo-Humming-birds-Cotinga-Campanere, or Bell-bird-Toucans, or Toucanets-Beak of the Toucan-Evanescence of the colours-The only mode of preserving them 


\section{CONTENTS}

\section{CHAPTER III}

The Houtou-Curious habit of trimming the tail and feathers -its habits-The Guianan Jay-The Boclora-Slight attachment of the feathers-The Cuia-Rice-birds-Cassiques, their habit of mockery-Pendulous nests-Gregarious nesting of different species-Wood-peckers of America and England-Kingfishers-Jacamars and their fly-catching habits-Troupiales and their songs-Tangaras-Manikins-Tiger-birds-Yawaraciri-Ant Thrushes-Parrot of the Sun-Aras, or Macaws-Bitterns-Egret, Herons, etc. -Goatsuckers-Whip-poor-Will-Superstitions - Tinamous -Powis and Maroudi-Horned Screamer-TrumpeterKing Vulture-Anhinga-Dangers of travel-Quartan ague .............................. 142-167

\section{THIRD 'JOURNEY}

\section{CHAPTER I}

From the Clyde to Demerara-Yellow fever-A deserted Plantation-Black John-Medicines for tropical climatesBats-The lancet-Severe accident and recovery-A primitive spear-History of the Sloth-An inhabitant of the trees-Structure of the limbs-A domesticated Sloth-A life of suspense-Structure of the hair-Mark on the back -Capture of a Sloth-Release and escape-Ants-Antbears-The great Ant-bear-Its powers of defence-Attitude when standing-How it catches its prey-Glutinous saliva-The Vampire and its habits-Bleeding gratisCoushie Ants-Armadillo and its habits-Tortoise-Eggs

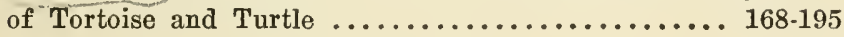

\section{CHAPTER II}

The Vanilla-Meaning of the word-Small Cayman-Daddy Quashi-Wasps-Venomous reptiles and wild beastsPoison of the Labarri snake-Experiment with a Labarri -The Bête-rouge-The Chegoe-Its nest-Ticks, and how to get rid of them-The five tribes-Their habitations and mode of life-Piwarri-The Pee-ay-man-A nation with- 
out a history-Runaway negroes-Mr. Edmonstone and his services-Wounded warriors-Valour rewarded-Education-Character of the native-Skill in hunting-A bead almanac-The sun as a compass-Thinness of population.

\section{CHAPTER III}

Discovery of a large Coulacanara snake-A Bush-masterStag swallowed by a Boa-Negroes and the snake-Arrangements for the attack-The snake struck-Carrying off the enemy-A snake in a bag-An unquiet night-Dissection of the snake-Daddy Quashi and his dread of snakes-Capture of a Coulacanara-Vultures and their food-Habits of Vultures-The Aura Vulture-Black Vultures-Severe blisters-An inquisitive Jaguar-Fish shooting-Goatsuckers and Campanero............ 214-231

\section{CHAPTER IV}

Fishing for a Cayman-A shark-hook useless-Sting-raysTurtle and Guana nests-Numbers of eggs-Another failure-Meeting a Jaguar-Guard against fever-More failures-A natire hook and way of baiting-The Cayman's dinner-bell-Caught at last-How to secure the reptileMounting a Cayman-An improvised bridle-Skin and teeth of the Cayman-Embarkment for England-Collision with the Custom House ................ 232-256

\section{FOURTH JOURNEY}

\section{CHAPTER I}

Three years in England-Sail for New York-Nomenclature -Alteration of scenery-A sprained ankle-Magnificent cure-Feats of climbing-Quebec-Irish emigrants-Ticonderoga-Saratoga-Philadelphia-White-hearled Eagle -Form and Fashion-Climato-Forebodings of the civil war-Sail for Antigua .................. 257-285 


\section{CHAPTER II}

Arrival at Antigua-Dominica-Frogs and Humming-birdsMartinico-Diamond rock-Barbadoes-Quashi and Venus -The Alien Bill-Sail for Demerara-More about the Sloth-Searlet Grosbeak-Crab-eating Owl-Sun-heronFeet of the Tinamou-Vampires again-The Karabimiti Humming-bird-The Monkey tribe-The Red HowlerRoast monkey-The Nondeseript-Altered physiognomyGold and silver mines-Changes of Government-Polities -India-rubber-An ingenious deception ......... 286-314

\section{ON PRESERVING BIRDS FOR CABINETS OF NATURAL}

\section{HISTORY}

Faults in bird-stuffing-Tools required-Knowledge of anatomy-Attitudes of birds-Flow of the plumage-How to skin a bird-Inserting cotton-Killing wounded birds-Stuffing a hawk-The first incision-The skin to be pushed, not pulled-Arrangement of wings-Modeling the body-Spreading the tail-Constant attention requiredStrength and elasticity-Value of corrosive sublimateExperience and patience .................. 315-332 



\section{LIS'T OF ILLUSTRA'TIONS}

\section{From Drawings by Charles Livingston Bull}

"The Emperor of all the Parrots"........... Frontispiece

Facing Page

"The Peccari herd together and traverse the wilds in all directions" ${ }^{\prime}$............................. 34

The Cock of the Rock...................... 58

Macoushia Indian with Blow-pipe................ 82

Blackbirds and Rattle-snake................... 120

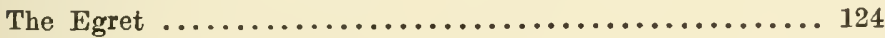

The Flight of the Toucan $\ldots \ldots \ldots \ldots \ldots \ldots \ldots \ldots \ldots \ldots \ldots \ldots \ldots$

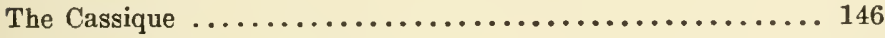

Trumpeter walking with his Master............... 160

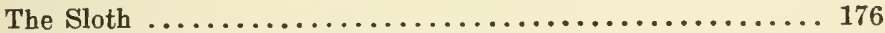

"The Ant-bear is a pacific animal" ............... 186

"I drove my fist, shielded by my hat, full in his jaws".... 222

"An immense Jaguar, standing on the trunk of an aged Mora-

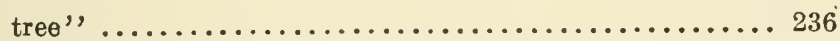

"I seized his forelegs, and twisted them on his back" ...... 244

"The water foamed, and dashed and boiled, amongst the

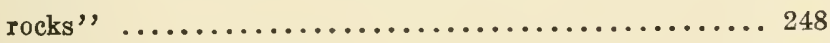

The Song of the Red Monkey ..................... 300 xvii 



\section{INTRODUCTION}

Many years ago, when reading this book for the first time, my boyish imagination was so fired that I determined the first opportunity should find me on my way to Waterton's beloved Demerara, and in March of the year 1908, I sailed from New York on a journey in which I covered most of the country which he describes so well and so thoroughly. There are but slight changes in the hundred years which have elapsed since he visited South America. The great exuberant jungles are just as dense and unbroken now as then; there are a very few new clearings and small settlements along the rivers, but some of those of his time have disappeared, and inland the immense range of forest still remains unbroken. I heard the weird night song of the red monkeys, the tolling of the bell bird, the coughing roar of the jaguar and the many other night sounds just as he must have heard them. The jungles are still alive with toucans, parrots, jacamars, trogons, motmots, cassiques, etc. Every little clearing is the gathering place of great numbers of such small birds as the hummingbirds, tanagers, flycatchers, and cotingas of many varieties and colors. I saw a few snakes, the camoudi or anaconda, the labarri, the bushmaster, or couanacouchi, and a most beautiful bright green parrot snake. 
The lizards and igmanas are very plentiful and interesting, and the insects are just as numerous and attentive as they were one hundred years ago. A week after my return to New York I happened to notice a small swelling on the side of my foot and upon examination found that it was a colony of chigoes that I had unwittingly smuggled past the Customs Inspectors. I quickly evicted them after Waterton's prescription and was much surprised to find that there neither was nor had been the slightest pain connected with their occupation or eviction. The ants were everywhere and tried to destroy everything. The ticks and bête-rouge were annoying at times, and the scorpions and centipedes were rather too plentiful, but there were great numbers of beautiful and interesting insects, splendid morphos, heliconias, papilios and many other butterflies in great variety and most gorgeous coloring: lovely great brown moths and resplendent jeweled beetles and dragonflies. Also many curious and remarkable forms of that little-known family, the leaf hoppers. The grasshoppers, locusts, cicadas and mantises grow to a great size and are most beautifully colored in greens, reds, yellows and browns.

The traveler in these immense forests may go for days and see no animal life save a few birds and insects, for the vegetation is so dense and matted together with lianas, bushropes, and orchid roots that the cover is perfect, and the largest animals can conceal themselves almost instantly. Even the great tapir, nearly as large as a cow, can thread its way noiselessly through 
the tangled undergrowth among the tree trunks, and the jaguar and puma or cougar can disappear in a single bound. The peccaries, of which there are great herds, scattered through the forest everywhere, can silently steal away, or if discovered go crashing and squealing among the great buttressed roots and trunks of the trees. I found that the only way to see the more timid beasts and birds was to go well into the jungle, sit down and keep perfectly still and they would come into sight. I found a great wild cashew tree, the fruit of which was ripe and falling and attracting many beasts and birds, and by taking up a position near its base I saw many curious little incidents of jungle life. I watched the timid agoutis, ever on the lookout for danger, come with short, jerky steps from under the great fallen leaves which everywhere strewed the ground. At the slightest movement or unusual sound they would disappear instantly. I was watching two of them one afternoon when hearing a slight sound behind me I very cautiously turned my head and discovered a peccary standing about twenty feet away, watching me most intently. I stared at him for a few moments, and then, remembering that they usually go in herds, I glanced about beyond him and made out another and yet another, both of them staring hard at me. I watched them for a few minutes, but at last, unable longer to bear the suspense, I moved a little, and with many squeals and grunts, they went rushing away, with eight or ten others which I had not seen before. The natives have no fear of these little black pigs, and say that they never 
attack man, but I found my nerves rather shaken, and I was very glad to see them disappear.

I found a pocket field glass to be of the greatest assistance, as with its aid I was able to identify many birds and beasts. Several times I found that what seemed to be merely a mass of greenish orchid roots was in reality a sloth, and once when examining through its lenses a large thatch-like nest of termites high in a tree, I noticed an excrescence on the nest and was able to make out a tamandua or ant-eater, which was making a meal of the insects. Several times I identified the cunning little sacawinki monkeys and marmosets watching me from a tree. What a great advantage Waterton would have found it, and likewise, how he would have enjoyed the pocket electric flash-light, that night when the jaguar investigated his camp. I found it of great value in identifying bats, and night-birds, as well as in finding which kinds of toads and frogs made the different notes of the chorus that swelled out every evening just at dusk.

I found the camera of comparatively little use, for the sun was too bright and the shade too dense. The heat and dampness spoiled my films and softened the glue which held together the camera, but then I am but an indifferent photographer at best, and another may well succeed where I failed.

The scenery is rather monotonous going up the Demerara River, but after crossing over to the Essequibo, it improves greatly and the islands, rocks, rapids, and the wooded hills are very beautiful-and the waterfalls are magnificent; the 
great Kaieteur Falls being several times as high as our Niagara, and nearly as great an amount of water going over it. 'The greatest beauty of the Guiana jungles, however, is not the scenic beauty of its broad landscapes, but the beauty of the intimate, the little bits, that go to make up the whole wonderful, fascinating jungle; a single orchid, for instance, growing high on a branch of a forest giant with strap-like leaves and lovely flowers and long aerial roots streaming down far below; or one of the big Arums with great heartshaped velvety leaves and curious blossoms called tail flowers. Every tree, plant and vine has its own beautiful or curious flower, or leaf, or both, and the flowers all have their attendant bees, wasps, butterflies or moths. The lovely jeweled hummingbirds go from one to another and add to the beauty of the little group, while on the twig beside the flower is perched a toucan or cotinga. The roots of the jungle trees are nearly always buttressed, great shoulders thrust out from the trunks, sometimes round and massive, but more often thin and flat, with edges hard and strong to resist the impact of falling trunks and branches, and too narrow to afford lodgement for seeds or parasites which are trying everywhere to gain a footing. On the ground between these great roots are masses of dead leaves, fruits, seeds and seed pods, of all shades of reds, yellows, and browns; and the dead trunks and branches are covered with most beautiful mosses and lichens. Everywhere is beauty; everywhere in the light of day are most lovely little pictures, and, when the shades of night have fallen, everywhere is 
tragedy and drama, for then the killers walk abroad, and they are many and very hungry. The jaguar leaves the great branch whereon he has slept away the day in the shadow of a mass of foliage. On the ground he reminds one of a great spotted bulldog, for his broad chest, massive shoulders, and thick bowed forelegs give him a rather stiff, heavy or "clumpy" walk, but in the trees he is at once the true cat, graceful, sinuous and blending in color with the lights and shadows. His sturdy body seems almost to change its entire character; he leaps easily from branch to leaning trunk, threads his way noiselessly through a tangle of vines, creeps out upon a big trunk overhanging the sandbar and leaps like a flash upon the timid Capybara, his favorite prey.

As he leisurely makes his meal, the great Cayman swims slowly up and down just at the edge of the sandbar, watching the great cat with cold, unwinking eye. Perhaps he is hoping the jaguar will leave a part of the game uneaten.

Out in midstream lies a school of the fish known as the Perai, waiting for the faintest taint of blood in the water, for though no larger than a very thick, muscular black bass of about four pounds' weight, they will kill anything which falls wounded into the water. Even the great Cayman himself, should he be torn by the claws of a jaguar caught by a sudden rush as it was drinking, would find his armor plate of no avail, for these wicked little killers are in such numbers, and can bite so savagely with their powerful jaws, that the bleeding scratch would iustantly be greatly enlarged 
and the monster reptile would be literally eaten alive. On the other hand, a small Cayman will dash fearlessly into a school of these fish and snap up as many as he can catch.

"Who is master of the Jungle?" said the great snake in Kipling's story, "Red Dog." There is no master of the jungle, for each master will find his master. Even the wild bees in that wonderful story are snapped up by the flycatchers.

Far in the forest a little band of red monkeys are sitting high in a giant palm, which spreads its great fan-leaves twenty feet out from the trunk. They sing their weird song in the moonlight, the most awe-inspiring sound in all animate nature. For twenty minutes or half an hour their night-song swells out in great pipe-organ chords, then dies slowly away, and the monkeys go roving over the roof of the jungle, leaping from branch to branch as they pass from one tree to another. Crossing a bridging liana, the leader suddenly stops and leaps back, but too late, for the beautifully mottled tree boa lying coiled on the liana has struck. Quicker than the leap of the frightened monkey, quicker than the stroke of a jaguar's paw, so quick that the eye of man could not follow it, the snake has struck and the big monkey is snatched from midair and is instantly wrapped in the tight coils, with every bone broken, every muscle crushed in one lightning stroke.

Everywhere in the jungle is beauty, everywhere is love and life, hate and death, feast and famine, but it is all most alluring. 
There is a saying in Demerara that, " $\mathrm{He}$ who has once eaten of the labba and drank of the bush water must come back to the jungle," and I feel as Waterton felt, that I, too, must one day go back.

Charles Livingston Bull. 


\section{WANDERINGS IN SOUTH AMERICA}





\section{MEMOIR}

Plutarch, the most famous biographer of ancient times, is of opinion that the uses of telling the history of the men of past ages are to teach wisdom, and to show us by their example how best to spend life. His method is to relate the history of a Greek statesman or soldier, then the history of a Roman whose opportunities of fame resembled those of the Greek, and finally to compare the two. $\mathrm{He}$ points out how in the same straits the one hero had shown wisdom, the other imprudence; and that he who had on one occasion fallen short of greatness had on another displayed the highest degree of manly virtue or of genius. If Plutarch's method of teaching' should ever be followed by an English biographer, he will surely place side by side and compare two English naturalists, Gilbert White and Charles Waterton. White was a clergyman of the Church of England, educated at Oxford. Waterton was a Roman Catholic country gentleman, who received his education in a Jesuit college. White spent his life in the south of England, and never travelled. Waterton lived in the north of England, and spent more than ten years in the forests of Guiana. With all these points of difference, the two naturalists were men of the same kind, and whose lives both teach the same lesson. They are examples to show that if a man will but look carefully round 


\section{WANDERINGS IN SOUTH AMERICA}

him in the couniry his every-day walk may supply him with an enjoyment costing nothing, but suryassed ky none which wealth can procure; with food for reflection however long he may live; with problems of which it will be an endless pleasure to attempt the solution; with a spectacle of Infinite Wisdom which will fill his mind with awe and with a constantly increasing assurance of Infinite Goodness, which will do much to help him in all the trials of life. He who lives in the country and has the love of outdoor natural history in his heart, will never be lonely and never dull. Waterton himself thought that this love of natural history must be inborn and could not be acquired. If this be so, they ought indeed to be thankful who possess so happy a gift. Even if Waterton's opinion be not absolutely true, it is at least certain that the taste for outdoor observation can only be acquired in the field, and that this acquisition is rarely made after the period of boyhood. How important, then, to excite the attention of children in the country to the sights around them. A few will remain apathetic, the tastes of some will lie in other directions, but the time will not be lost, for some will certainly take to natural history, and will have happiness from it throughout life. No study is more likely to confirm them in that content of which a favourite poet of Waterton's truly says:-

"Content is wealth, the riches of the mind, And happy he who can that treasure find."

Gilbert White and Charles Waterton are preeminent among English naturalists for their com- 
plete devotion to the study; both excelled as observers, and the writings of both combine the interest of exact outdoor observation with the charm of good literature. Waterton was born on June 3rd, 1782, at Walton Hall, in the West Riding of Yorkshire, a place which had for several centuries been the seat of his family. His father, Thomas Waterton, was a squire, fond of fox-hunting, but with other tastes, well read in literature, and delighting in the observation of the ways of birds and beasts. His grandfather, whose grave is beneath the most northern of a row of old elm trees in the park, was imprisoned in York on account of his known attachment to the cause of the Young Pretender. As he meant to join the rebel forces, the imprisonment probably saved his own life and prevented the ruin of the family. In his grandson's old age, when another white-haired Yorkshire squire was dining at Walton Hall, I remember that Waterton and he reminded one another that their grandfathers had planned to march together to Prince Charley, and that they themselves, so differently are the rights of kings regarded at different ages, when schoolboys together, hał gone a-bird's-nesting on a day, in 1793, set apart for mourning for the decapitation of Louis XVI. Waterton has himself told the history of his earlier ancestors in an autobiography which he wrote in 1837 :-

"The poet tells us, that the good qualities of man and of cattle descend to their offspring. 'Fortes creantur fortibus et bonis.' If this holds good, I ought to be pretty well off, as far as breeding goes; for, on the father's side, I come 
in a direct line from Sir Thomas More, through my grandmother; whilst by the mother's side I am akin to the Bedingfelds of Oxburgh, to the Charltons of Hazelside, and to the Swinburnes of Capheaton. My family has been at Walton Hall for some centuries. It emigrated into Yorkshire from Waterton, in the island of Axeholme in Lincolnshire, where it had been for a very long time. Indeed, I dare say I could trace it up to Father Adam, if my progenitors had only been as careful in preserving family records as the Arabs are in recording the pedigree of their horses; for I do most firmly believe that we are all descended from Adam and his wife Eve, notwithstanding what certain self-sufficient philosophers may have advanced to the contrary. Old Matt Prior had probably an opportunity of laying his hands on family papers of the same purport as those which I have not been able to find; for he positively informs us that Adam and Eve were his ancestors:-

'Gentlemen, here, by your leave,

Lie the bones of Matthew Prior,

A son of Adam and of Eve:

Can Bourbon or Nassau go higher?'

Depend upon it, the man under Afric's burning zone, and he from the frozen regions of the North, have both come from the same stem. Their difference in colour and in feature may be traced to this: viz., that the first has had too much, and the second too little, sun.

"In remote times, some of my ancestors were sufficiently notorious to have had their names handed down to posterity. They fought at Cressy, 
and at Agincourt, and at Marston Moor. Sir. Robert Waterton was Governor of Pontefract Castle, and had charge of King Richard II. Sir Hugh Waterton was executor to his Sovereign's will, and guardian to his daughters. Another ancestor was sent into France by the King, with orders to contract a royal marriage. He was allowed thirteen shillings a day for his trouble and travelling expenses. Another was Lord Chancellor of England, and preferred to lose his head rather than sacrifice his conscience."

Waterton's childhood was spent at Walton Hall, and in his old age he used sometimes to recall the songs of his nurses. "One of them," he said, "is the only poem in which the owl is pitied. She sang it to the tune of "Cease, rude Boreas, blustering railer,' and the words are affecting:-

\footnotetext{
'Once I was a monarch's daughter, And sat on a lady's knee;

But am now a nightly rover, Banished to the ivy tree.

'Crying, Hoo, hoo, hoo, hoo, hoo, hoo, Hoo, hoo, my feet are cold!

Pity me, for here you see me Persecuted, poor, and old.',
}

He was already proficient in bird's-nesting when, in 1792, he was sent to a school kept by a Roman Catholic priest, the Reverend Arthur Storey, at Tudhoe, then a small village, five miles from Durham. Three years before his death he wrote an account of his school days, which is printed in the Life prefixed to Messrs. Warne's edition of his "Natural History Essays." The 
honourable character of the schoolmaster, and the simple, adventurous disposition of his pupil, are vividly depicted in this account. The following quotations from it show that preparatory schools were less luxurious in the last century than they commonly are at the present day:-

"But now let me enter into the minutiæ of Tudhoe School. Mr. Storey had two wigs, one of which was of a flaxen colour, without powder, and had only one lower row of curls. The other had two rows, and was exceedingly well powdered. When he appeared in the schoolroom with this last wig on, I knew that I was safe from the birch, as he invariably went to Durham and spent the day there. But when I saw that he had his flaxen wig on, my countenance fell. He was in the schoolroom all day, and I was too often placed in a very uncomfortable position at nightfall. But sometimes I had to come in contact with the birchrod for various frolies independent of school erudition. I once smarted severely for an act of kindness. We had a boy named Bryan Salvin, from Croxdale Hall. He was a dull, sluggish, and unwieldy lad, quite incapable of climbing exertions. Being dissatisfied with the regulations of the establishment, he came to me one Palm Sunday, and entreated me to get into the schoolroom through the window, and write a letter of complaint to his sister Eliza in York. I did so, having insinuated myself with vast exertion through the iron stanchions which secured the window; 'sed revocare gradum.' Whilst I was thrusting might and main through the stanchions, on my way out -suddenly, oh, horrible! the schoolroom door flew 
open, and on the threshold stood the Reverend Mr. Storey - a fiery, frightful, formidable spectre! To my horror and confusion I drove my foot quite through a pane of glass, and there I stuck, impaled and imprisoned, but luckily not injured by the broken glass. Whilst I was thus in unexpected captivity, he cried out, in an angry voice, 'So you are there, Master Charles, are you?' He got assistance, and they pulled me back by main force. But as this was Palm Sunday my execution was obligingly deferred until Monday morning.

"But let us return to Tudhoe. In my time it was a peaceful, healthy farming village, and abounded in local curiosities. Just on the king's highway, betwixt Durham and Bishop-Auckland, and one field from the school, there stood a publichouse called the 'White Horse,' and kept by a man of the name of Charlton. He had a real gaunt English mastiff, half-starved for want of food, and so ferocious that nobody but himself dared to approach it. This publican had also a mare, surprising in her progeny; she had three foals, in three successive years, not one of which had the least appearance of a tail.

"One of Mr. Storey's powdered wigs was of so tempting an aspect, on the shelf where it was laid up in ordinary, that the cat actually kittened in it. I saw her and her little ones all together in the warm wig. He also kept a little white and black bitch, apparently of King Charles's breed. One evening, as we scholars were returning from a walk, Chloe started a hare, which we surrounded and captured, and carried in triumph to oily 
Mrs. Atkinson, who begged us a play-day for our success.

"On Easter Sunday Mr. Storey always treated us to 'Pasche eggs.' They were boiled hard in a concoction of whin-flowers, which rendered them beautifully purple. We used them for warlike purposes, by holding them betwixt our forefinger and thumb with the sharp end upwards, and as little exposed as possible. An antagonist then approached, and with the sharp end of his own egg struck this egg. If he succeeded in cracking it, the vanquished egg was his; and he either sold it for a halfpenny in the market, or reserved it for his own eating. When all the sharp ends had been crushed, then the blunt ends entered into battle. Thus nearly every Pasche egg in the school had its career of combat. The possessor of a strong egg with a thick shell would sometimes vanquish a dozen of his opponents, all of which the conqueror ultimately transferred into his own stomach, when no more eggs with unbroken ends remained to carry on the war of Easter Week.

"The little black and white bitch once began to snarl, and then to bark at me, when I was on a roving expedition in quest of hens' nests. I took up half a brick and knocked it head over heels. Mr. Storey was watching at the time from one of the upper windows; but I had not seen him, until I heard the sound of his magisterial voice. He beckoned me to his room there and then, and whipped me soundly for my pains.

"Four of us scholars stayed at Tudhoe during the summer vacation, when all the rest had gone home. 'Two of these had dispositions as malicious 
as those of two old apes. One fine summer's morning they decoyed me into a field (I was just then from my mother's nursery) where there was a flock of geese. They assured me that the geese had no right to be there; and that it was necessary we should kill them, as they were trespassing on our master's grass. The scamps then furnished me with a hedge-stake. On approaching the flock, behold the gander came out to meet me; and whilst he was hissing defiance at us, I struck him on the neck, and killed him outright. My comrades immediately took to flight, and on reaching the house informed our master of what I had done. But when he heard my unvarnished account of the gander's death, he did not say one single unkind word to me, but scolded most severely the two boys who had led me into the scrape. The geese belonged to a farmer named John Hey, whose son Ralph used to provide me with birds' eggs. Ever after when I passed by his house, some of the children would point to me and say, 'Yaw killed aur guise.'

"At Bishop-Auckland there lived a man by the name of Charles the Painter. He played extremely well on the Northumberland bagpipe, and his neighbour was a good performer on the flageolet. When we had pleased our master by continued good conduct, he would send for these two musicians, who gave us a delightful evening concert in the general play-room, Mr. Storey himself supplying an extra treat of fruit, cakes, and tea.

"Tudhoe had her own ghosts and spectres, just as the neighbouring villages had theirs. One was the Tudhoe mouse, well-known and often seen in 
every house in the village; but I cannot affirm that I myself ever saw it. It was an enormous mouse, of a dark brown colour, and did an immensity of mischief. No cat could face it; and as it wandered through the village, all the dogs would take off, frightened out of their wits, and howling as they ran away. William Wilkinson, Mr. Storey's farming man, told me he had often seen it, but that it terrified him to such a degree that he could not move from the place where he was standing.

"Our master kept a large tom-cat in the house. A fine young man, in the neighbouring village of Ferrylill, had been severely bitten by a cat, and he died raving mad. On the day that we got this information from Timothy Pickering, the carpenter at Tudhoe, I was on the prowl for adventures, and in passing through Mr. Storey's back kitchen, his big black cat came up to me. Whilst I was tickling its bushy tail, it turned round upon me, and gave me a severe bite in the calf of the leg. This I kept a profound secret, but I was quite sure I should go mad every day, for many months afterwards.

"There was a blacksmith's shop leading down the village to Tudhoe Old Hall. Just opposite this shop was a pond, on the other side of the road. When any sudden death was to take place, or any sudden ill to befall the village, a large black horse used to emerge from it, and walk slowly up and down the village, carrying a rider without a head. The blacksmith's grandfather, his father, himself, his three sons, and two daughters, had seen this midnight apparition rise out of the pond, and re- 
turn to it before the break of day. John Hickson and Neddy Hunt, two hangers-on at the blacksmith's shop, had seen this phantom more than once, but they never durst approach it. Indeed, every man and woman and child believed in this centaur-spectre, and I am not quite sure if our old master himself did not partly believe that such a thing had occasionally been seen on very dark nights.

"Tudhoe has no river, a misfortune "valde deflendus.' In other respects the vicinity was charming; and it afforded an ample supply of woods and hedgerow trees to insure a sufficient stock of carrion crows, jackdaws, jays, magpies, brown owls, kestrels, merlins, and sparrow-hawks, for the benefit of natural history and my own instruction and amusement."

In 1796 Waterton left Tudhoe School and went to Stonyhurst College in Lancashire. It was a country house of the picturesque style of King James I., which had just been made over by Mr. Weld of Lulworth to the Jesuits expelled from Liége. The country round Stonyhurst is varied by hills and streams, and there are mountains at no great distance.

\footnotetext{
"Whernside, Pendle Hill, and Ingleboro",

Three higher hills you'll not find England thoro',"
}

as they are described, with equal disregard of exact mensuration and of rhythm, in a local rhyme which Waterton learned. Curlew used to fly by in flocks, and the country people had also a rhyme about the curlew :- 
"Be she white or be she black, She carries sixpence on her back,"

which Waterton used to say showed how our ancestors valued the bird at table.

At Stonyhurst he read a good deal of Latin and of English literature, and acquired a taste for writing Latin verse. He always looked back on his edncation there with satisfaction, and in afterlife often went to visit the college. Throughout life he never drank wine, and this fortunate habit was the result of the good advice of one of his teachers:-

"My master was Father Clifford, a first cousin of the noble lord of that name. He had left the world, and all its alluring follies, that he might serve Almighty God more perfectly, and work his way with more security up to the regions of eternal bliss. After educating those entrusted to his charge with a care and affection truly paternal, he burst a blood-vessel, and retired to Palermo for the benefit of a warmer climate. There he died the death of the just, in the habit of St. Ignatius.

"One day, when I was in the class of poetry, and which was about two years before I left the college for good and all, he called me up to his room. 'Charles,' said he to me, in a tone of voice perfectly irresistible, 'I have long been studying' your disposition, and I clearly foresee that nothing will keep you at home. You will journey into far-distant countries, where you will be exposed to many dangers. There is only one way for you to escape them. Promise me that, from this day forward, you will never put your lips to wine, or 
to spirituous liquors.' 'The sacrifice is nothing,' added he; 'but, in the end, it will prove of incalculable advantage to you.' I agreed to his enlightened proposal; and from that hour to this, which is now about nine-and-thirty years, I have never swallowed one glass of any kind of wine or of ardent spirits."

After leaving college Waterton stayed at home with his father, and enjoyed fox-hunting for a while. To the end of his days he liked to hear of a good run, and he would now and then look with pleasure on an engraving which hung in the usual dining-room at Walton Hall, representing Lord Darlington, the first master of hounds he had known, well seated on a powerful horse and surrounded by very muscular hounds. In 1802 he went to visit two uncles in Spain, and stayed for more than a year, and there had a terrible experience of pestilence and of earthquake:-

"There began to be reports spread up and down the city that the black vomit had made its appearance; and every succeeding day brought testimony that things were not as they ought to be. I myself, in an alley near my uncles' house, saw a mattress of most suspicious appearance hung out to dry. A Maltese captain, who had dined with us in good health at one o'clock, lay dead in his cabin before sunrise the next morning. A few days after this I was seized with vomiting and fever during the night. I had the most dreadful spasms, and it was supposed that I could not last out till noon the next day. However, strength of constitution got me through it. In three weeks more, multitudes were seen to leave the city, which shortly after 


\section{WANDERINGS IN SOUTH AMERICA}

was declared to be in a state of pestilence. Some affirmed that the disorder had come from the Levant; others said that it had been imported from the Havanna; but I think it probable that nobody could tell in what quarter it had originated.

"We had now all retired to the country-house -my eldest uncle returning to Malaga from time to time, according as the pressure of business demanded his presence in the city. He left us one Sunday evening, and said he would be back again some time on Monday; but that was my poor uncle's last day's ride. On arriving at his house in Malaga, there was a messenger waiting to inform him that Father Bustamante had fallen sick, and wished to see him. Father Bustamante was an aged priest, who had been particularly kind to my uncle on his first arrival in Malaga. My uncle went immediately to Father Bustamante, gave him every consolation in his power, and then returned to his own house very unwell, there to die a martyr to his charity. Father Bustamante breathed his last before daylight; my uncle took to his bed, and never rose more. As soon as we had received information of his sickness, I immediately set out on foot for the city. His friend, Mr. Power, now of Gibraltar, was already in his room, doing everything that friendship could suggest or prudence dictate. My uncle's athletic constitution bore up against the disease much longer than we thought it possible. He struggled with it for five days, and sank at last about the hour of sunset. He stood six feet four inches high; and was of so kind and generous a disposition, that he was beloved by all who knew him. 
Many a Spanish tear flowed when it was known that he had ceased to be. We got him a kind of coffin made, in which he was conveyed at midnight to the outskirts of the town, there to be put into one of the pits which the galley-slaves had dug during the day for the reception of the dead. But they could not spare room for the coffin; so the body was taken out of it, and thrown upon the heap which already occupied the pit. A Spanish marquis lay just below him.

"Thousands died as though they had been seized with cholera, others with black vomit, and others of decided yellow fever. There were a few instances of some who departed this life with very little pain or bad symptoms: they felt unwell, they went to bed, they had an idea that they would not get better, and they expired in a kind of slumber. It was sad in the extreme to see the bodies placed in the streets at the close of day, to be ready for the dead-carts as they passed along. The dogs howled fearfully during the night. All was gloom and horror in every street; and you might see the vultures on the strand tugging at the bodies which were washed ashore by the eastern wind. It was always said that 50,000 people left the city at the commencement of the pestilence; and that 14,000 of those who remained in it fell victims to the disease.

"There was an intrigue going on at court, for the interest of certain powerful people, to keep the port of Malaga closed long after the city had been declared free from the disorder; so that none of the vessels in the mole could obtain permission to depart for their destination. 
"In the meantime the city was shaken with earthquakes; shock succeeding shock, till we all imagined that a catastrophe awaited us similar to that which had taken place at Lisbon. The pestilence killed you by degrees, and its approaches were sufficiently slow, in general, to enable you to submit to it with firmness and resignation; but the idea of being swallowed up alive by the yawning earth at a moment's notice, made you sick at heart, and rendered you almost fearful of your own shadow. The first shock took place at six in the evening, with a noise as though a thousand carriages had dashed against each other. This terrified many people to such a degree that they paced all night long up and down the Alameda, or public walk, rather than retire to their homes. I went to bed a little after midnight, but was roused by another shock about five o'clock in the morning. It gave the bed a motion which made me fancy that it moved under me from side to side. I sprang up, and having put on my unmentionables (we wore no trousers in those days), I ran out, in all haste, to the Alameda. There the scene was most distressing: multitudes of both sexes, some nearly in a state of nudity, and others sick at stomach, were huddled together, not knowing which way to turn or what to do.

\section{'Omnes eodem cogimur.'}

However, it pleased Heaven, in its mercy, to spare us. The succeeding shocks became weaker and weaker, till at last we felt no more of them."

A courageous sea-captain at last sailed away in safety, though chased by the Spanish brigs of 
war, and after thirty days at sea Waterton landed in England.

Another uncle had estates in Demerara, and in the autumn Waterton sailed thither from Portsmouth. He landed at Georgetown, Demerara, in November, 1804, and was soon delighted by the natural history of the tropical forest. In 1806 his father died, and he returned to England. He made four more journeys to Guiana, and, in 1825, published an account of them, entitled "Wanderings in South America, the North-West of the United States, and the Antilles, in the years 1812, 1816, 1820, and 1824; with original instructions for the perfect preservation of birds, \&c., for cabinets of natural history." The book at once attracted general attention, became popular, and has taken a place among permanent English literature. Unlike most travellers, Waterton tells nothing of his personal difficulties and discomforts, and encumbers his pages with neither statistics nor information of the guide-book kind. His observation of birds and beasts, written down in the forests, and the description of the forests themselves, fill all his pages. The great ant-eater and the sloth were for the first time accurately described by him. He showed that the sloth, instead of being a deformed, unhappy creature, was admirably adapted to its habitat. He explained the use of the great claws of the ant-eater, and the curious gait which they necessitated. The habits of the toucan, of the houtou, of the campanero, and of many other birds, were first correctly described by him. He determined to catch a cayman or alligator, and 
at last hooked one with a curious wooden hook of four barbs made for him by an Indian.

The adventure which followed is perhaps one of the most famous exploits of an English naturalist.

"We found a cayman, ten feet and a half long, fast to the end of the rope. Nothing now remained to do, but to get him out of the water without injuring his scales, 'hoc opus, hic labor.' We mustered strong: there were three Indians from the creek, there was my own Indian, Yan; Daddy Quashi, * the negro from Mrs. Peterson's; James, Mr. R. Edmonstone's man, whom I was instructing to preserve birds; and, lastly, myself.

"I informed the Indians that it was my intention to draw him quietly out of the water, and then secure him. They looked and stared at each other, and said I might do it myself, but they would have no hand in it; the cayman would worry some of us. On saying this, 'consedere duces,' they squatted on their hams with the most perfect indifference.

"The Indians of these wilds have never been subject to the least restraint; and I knew enough of them to be aware, that if I tried to force them against their will, they would take off, and leave me and my presents unheeded, and never return.

"Daddy Quashi was for applying to our guns, as usual, considering them our best and safest

* The negroes of the West Coast of Africa, as I am informed by Dr. Kodjoe Benjamin William Kwatei-kpakpafio, of Accra, take their names from the day of the week on which they are born: Quashi (Kwasi) is Sunday; Kodjoe, Monday; Koffie, Tuesday. - N. M. 
friends. I immediately offered to knock him down for his cowardice, and he shrank back, begging that I would be cautious, and not get myself worried; and apologising for his own want of resolution. My Indian was now in conversation with the others, and they asked me if I would allow them to shoot a dozen arrows into him, and thus disable him. This would have ruined all. I had come above three hundred miles on purpose to get a cayman uninjured, and not to carry back a mutilated specimen. I rejected their proposition with firmness, and darted a disdainful eye upon the Indians.

"Daddy Quashi was again beginning to remonstrate, and I chased him on the sand-bank for a quarter of a mile. He told me afterwards, he thought he should have dropped down dead with fright, for he was firmly persuaded, if I had caught him, I should have bundled him into the cayman's jaws. Here then we stood, in silence, like a calm before a thunder-storm. "Hoc res summa loco. Scinditur in contraria vulgus.' 'They wanted to kill him, and I wanted to take him alive.

"I now walked up and down the sand, revolving a dozen projects in my head. The canoe was at a considerable distance, and I ordered the people to bring it round to the place where we were. The mast was eight feet long, and not much thicker than my wrist. I took it out of the canoe, and wrapped the sail round the end of it. Now it appeared clear to me, that if I went down upon one knee, and held the mast in the same position as the soldier holds his bayonet when rushing to the charge, I could force it down the cayman's throat, 
should he come open-mouthed at me. When this was told to the Indians, they brightened up, and said they would help me to pull him out of the river.

" 'Brave squad!' said I to myself, " Audax omnia perpeti," now that you have got me betwixt yourselves and danger.' I then mustered all hands for the last time before the battle. We were, four South American savages, two negroes from Africa, a creole from Trinidad, and myself, a white man from Yorkshire. In fact, a little Tower of Babel group, in dress, no dress, address and language.

"Daddy Quashi hung in the rear; I showed him a large Spanish knife, which I always carried in the waistband of my trousers: it spoke volumes to him, and he shrugged up his shoulders in absolute despair. The sun was just peeping over the high forests on the eastern hills, as if coming to look on, and bid us act with becoming fortitude. I placed all the people at the end of the rope, and ordered them to pull till the cayman appeared on the surface of the water; and then, should he plunge, to slacken the rope and let him go again into the deep.

"I now took the mast of the canoe in my hand (the sail being tied round the end of the mast) and sank down upon one knee, about four yards from the water's edge, determining to thrust it down his throat, in case he gave me an opportunity. I certainly felt somewhat uncomfortable in this situation, and I thought of Cerberus on the other side of the Styx ferry. The people pulled the cayman to the surface; he plunged furiously as 
soon as he arrived in these upper regions, and immediately went below again on their slackening the rope. I saw enough not to fall in love at first sight. I now told them we would run all risks, and have him on land immediately. They pulled again, and out he came-'monstrum horrendum, informe.' This was an interesting moment. I kept my position firmly, with my eye fixed steadfast on him.

"By the time the cayman was within two yards of me, I saw he was in a state of fear and perturbation: I instantly dropped the mast, sprang up, and jumped on his back, turning half round as I vaulted, so that I gained my seat with my face in a right position. I immediately seized his forelegs, and by main force twisted them on his back; thus they served me for a bridle.

"He now seemed to have recovered from his surprise, and probably fancying himself in hostile company, he began to plunge furiously, and lashed the sand with his long and powerful tail. I was out of reach of the strokes of it, by being near his head. He continued to plunge and strike, and made my seat very uncomfortable. It must have been a fine sight for an unoccupied spectator.

"The people roared out in triumph, and were so vociferous, that it was some time before they heard me tell them to pull me and my beast of burthen farther inland. I was apprehensive the rope might break, and then there would have been every chance of going down to the regions under water with the cayman. That would have been more perilous than Arion's marine morning ride :-

'Delphini insidens vada cærula suleat Arion.' 
"The people now dragged us about forty yards on the sand; it was the first and last time I was ever on a cayman's back. Should it be asked, how I managed to keep my seat, I would answer-I hunted some years with Lord Darlington's foxhounds.

"After repeated attempts to regain his liberty, the cayman gave in, and became tranquil through exhaustion. I now managed to tie up his jaws, and firmly secured his fore-feet in the position I had held them. We had now another severe struggle for superiority, but he was soon overcome, and again remained quiet. While some of the people were pressing upon his head and shoulders, I threw myself on his tail, and by keeping it down to the sand, prevented him from kicking up another dust. He was finally conveyed to the canoe, and then to the place where we had suspended our hammocks. There I cut his throat; and after breakfast was over commenced the dissection."

After his fourth journey Waterton occasionally travelled on the Continent, but for the most part resided at Walton Hall. In the park he made the observations afterwards published as "Essays on Natural History," in three series, and since reprinted, with his Life and Letters.

Walton Hall is situated on an island surrounded by its ancient moat, a lake of about fiveand-twenty acres in extent. From the shores of the lake the land rises; parts of the slope, and nearly all the highest part, being covered with wood.

In one wood there was a large heronry, in another a rookery. Several hollow trees were 
haunted by owls; in the summer goat-suckers were always to be seen in the evening flying about two oaks on the hill. At one end of the lake in summer the kingfisher might be watched fishing, and throughout the year herons waded round its shores picking up fresh-water mussels, or stood motionless for hours, watching for fish. In winter, when the lake was frozen, three or four hundred wild duck, with teal and pochards, rested on it all day, and flew away at night to feed; while widgeons fed by day on its shores. Coots and water hens used to come close to the windows and pick up food put out for them. The Squire built a wall nine feet high all round his park, and he used laughingly to say that he paid for it with the cost of the wine which he did not drink after dinner.

A more delightful home for a naturalist could not have been. No shot was ever fired within the park wall, and every year more birds came. Waterton used often to quote the lines:-

\footnotetext{
"No bird that haunts my valley free To slaughter I condemn;

Taught by the Power that pities me,

I learn to pity them;",
}

and each new-comer added to his happiness. In his latter days the household usually consisted of the Squire, as he was always called, and of his two sisters-in-law, for he had lost his wife soon after his marriage in 1829. He breakfasted at eight, dined in the middle of the day, and drank tea in the evening. He went to bed early, and slept upon the bare floor, with a block of wood for his pillow. 
He rose for the day at half-past three, and spent the hour from four to five at prayer in his chapel. He then read every morning a chapter in a Spanish Life of St. Francis Xavier, followed by a chapter of "Don Quixote" in the original, after which he used to stuff birds or write letters till breakfast. Most of the day he spent in the open air, and when the weather was cold would light a fire of sticks and warm himself by it. So active did he continue to the end of his days, that on his eightieth birthday he climbed an oak in my company. He was very kind to the poor, and threw open a beautiful part of his park to excursionists all through the summer. He had a very tender heart for beasts and birds, as well as for men. If a cat looked hungry he would see that she had a meal, and sometimes when he had forgotten to put a crust of bread in his pocket before starting on his afternoon walk, he would say to his companion, "How shall we ever get past that goose?" for there was a goose which used to wait for him in the evening at the end of the bridge over the moat, and he could not bear to disappoint it. If he could not find a bit of food for it, he would wait at a distance till the bird went away, rather than give it nothing when it raised its bill.

Towards the end of his life I enjoyed his friendship, and can never forget his kindly welcome, his pithy conversation, the happy humour with which he expressed the conclusions of his long experience of men, birds and beasts, and the goodness which shone from his face. I was staying at Walton when he died, and have thus described his last hours in the biography which is prefixed 
to the latest edition of his Essays. I was reading for an examination, and used, on the Squire's invitation, to go and chat with him just after midnight, for at that hour he always awoke, and paid a short visit to his chapel. A little before midnight on May 24th I visited him in his room. He was sitting asleep by his fire wrapped up in a large Italian cloak.

His head rested upon his wooden pillow, which was placed on a table, and his thick silvery hair formed a beautiful contrast with the dark colour of the oak. He soon woke up, and withdrew to the chapel, and on his return we talked together for three-quarters of an hour about the brown owl, the nightjar, and other birds. The next morning, May 25, he was unusually cheerful, and said to me, "That was a very pleasant little confab we had last night: I do not suppose there was such another going on in England at the same time." After breakfast we went with a carpenter to finish some bridges at the far end of the park. The work was completed, and we were proceeding homewards when, in crossing a small bridge, a bramble caught the Squire's foot, and he fell heavily upon a log. He was greatly shaken, and said he thought he was dying. He walked, notwithstanding, a little way, and was then compelled to lie down. He would not permit his sufferings to distract his mind, and he pointed out to the carpenter some trees which were to be felled. He presently continued his route, and managed to reach the spot where the boat was moored. Hitherto he had refused all assistance, but he could not step from the bank into the boat, and he said, "I 
am afraid I must ask you to help me in." He walked from the landing-place into the house, changed his clothes, and came and sat in the large room below. The pain increasing, he rose from his seat after he had seen his doctor, and though he had been bent double with anguish, he persisted in walking up-stairs without help, and would have gone to his own room in the top storey, if, for the sake of saving trouble to others, he had not been induced to stop half-way in Miss Edmonstone's sitting-room. Here he lay down upon the sofa, and was attended by his sisters-in-law. The pain abated, and the next day he seemed better. In the afternoon he talked to me a good deal, chiefly about natural history. But he was well aware of his perilous condition, for he remarked to me, "This is a bad business," and later on he felt his pulse often, and said, "It is a bad case." He was more than self-possessed. A benignant cheerfulness beamed from his mind, and in the fits of pain he frequently looked up with a gentle smile, and made some little joke. Towards midnight he grew worse. The priest, the Reverend R. Browne, was summoned, and Waterton got ready to die. He pulled himself upright without help, sat in the middle of the sofa, and gave his blessing in turn to his grandson, Charlie, to his grand-daughter, Mary, to each of his sisters-in-law, to his niece, and to myself, and left a message for his son, who was hastening back from Rome. He then received the last sacraments, repeated all the responses, Saint Bernard's hymn in English, and the first two verses of the Dies Ire. The end was now at hand, and he died at twenty-seven minutes past 
two in the morning of May 27, 1865. The window was open. The sky was beginning to grow grey, a few rooks had cawed, the swallows were twittering, the landrail was craking from the ox-close, and a favourite cock, which he used to call his morning gun, leaped out from some hollies, and gave his accustomed crow. The ear of his master was deaf to the call. He had obeyed a sublimer summons, and had woke up to the glories of the eternal world.

He was buried on his birthday, the 3rd of June, between two great oaks at the far end of the lake, the oldest trees in the park. He had put up a rough stone cross to mark the spot where he wished to be buried. Often on summer days he had sat in the shade of these oaks watching the kingfishers. "Cock Robin and the magpies," he said to me as we sat by the trees one day, "will mourn my loss, and you will sometimes remember me when I lie here." At the foot of the cross is a Latin inscription which he wrote himself. It could hardly be simpler: "Pray for the soul of Charles Waterton, whose tired bones are buried near this cross." The dates of his birth and death are added.

Walton Hall is no longer the home of the Watertons, the oaks are too old to flourish many years more, and in time the stone cross may be overthrown and the exact burial place of Waterton be forgotten; but his "Wanderings in South America" and his "Natural History Essays" will always be read, and are for him a memorial like that claimed by the poet he read oftenest-

"quod nec Jovis ira, nec ignes,

Nec poterit ferrum, nec edax abolere vetustas.',

Norman Moore. 



\title{
Wanderings in South America
}

\section{FIRST JOURNEY}

\author{
CHAPTER I \\ "nec herba, nec latens in asperis \\ Radix fefellit me locis."
}

In the month of April, 1812, I left the town of Stabroek, to travel through the wilds of Demerara and Essequibo, a part of ci-devant Dutch Guiana, in South America.

The chief objects in view were to collect a quantity of the strongest Wourali-poison; and to reach the inland frontier fort of Portuguese Guiana.

It would be a tedious journey for him who wishes to travel through these wilds, to set out from Stabroek on foot. The sun would exhaust him in his attempts to wade through the swamps, and the Mosquitos at night would deprive him of every hour of sleep.

The road for horses runs parallel to the river, but it extends a very little way, and even ends before the cultivation of the plantation ceases.

The only mode then that remains is to proceed 
by water; and when you come to the high lands, you may make your way through the forest on foot, or continue your route on the river.

After passing the third island in the river Demerara, there are few plantations to be seen, and those not joining on to one another, but separated by large tracts of wood.

The Loo is the last where the Sugar-cane is growing. The greater part of its negroes have just been ordered to another estate; and ere a few months shall have elapsed all signs of cultivation will be lost in underwood.

Higher up stand the sugar-works of Amelia's Waard, solitary and abandoned! and after passing these there is not a ruin to inform the traveller that either coffee or sugar have ever been cultivated.

From Amelia's Waard an unbroken range of forest covers each bank of the river, saving here and there where a hut discovers itself, inhabited by free people of colour, with a rood or two of bared ground about it; or where the wood-cutter has erected himself a dwelling, and cleared a few acres for pasturage. Sometimes you see level ground on each side of you for two or three hours at a stretch; at other times a gently sloping hill presents itself; and often, on turning a point, the eye is pleased with the contrast of an almost perpendicular height jutting into the water. The trees put you in mind of an eternal spring, with summer and autumn kindly blended into it.

Here you may see a sloping extent of noble trees, whose foliage displays a charming variety of every shade, from the lightest to the darkest 
green and purple. 'The tops of some are crowned with bloom of the loveliest hue; while the boughs of others bend with a profusion of seeds and fruits.

Those whose heads have been bared by time, or blasted by the thunder-storm, strike the eye, as a mournful sound does the ear in music; and seem to beckon to the sentimental traveller to stop a moment or two, and see that the forests which surround him, like men and kingdoms, have their periods of misfortune and decay.

The first rocks of any considerable size that are observed on the side of the river are at a place called Saba, from the Indian word, which means a stone. They appear sloping down to the water's edge, not shelvy, but smooth, and their exuberances rounded off, and, in some places, deeply furrowed, as though they had been worn with continual floods of water.

There are patches of soil up and down, and the huge stones amongst them produce a pleasing and novel effect. You see a few Coffee-trees of a fine luxuriant growth; and nearly on the top of Saba stands the house of the post-holder.

$\mathrm{He}$ is appointed by government to give in his report to the protector of the Indians of what is going on amongst them, and to prevent suspicious people from passing up the river.

When the Indians assemble here the stranger may have an opportunity of seeing the Aborigines dancing to the sound of their country music, and painted in their native style. They will shoot their arrows for him with an unerring aim, and send the poisoned dart from the blow-pipe true 
to its destination; and here he may often view all the different shades, from the red savage to the white man, and from the white man to the sootiest son of Africa.

Beyond this post there are no more habitations of white men, or free people of colour.

In a country so extensively covered with wood as this is, having every advantage that a tropical sun and the richest mould, in many places, can give to vegetation, it is natural to look for trees of very large dimensions; but it is rare to meet with them above six yards in circumference. If larger have ever existed, they have fallen a sacrifice either to the axe or to fire.

If, however, they disappoint you in size, they make ample amends in height. Heedless and bankrupt in all curiosity must he be who can journey on without stopping to take a view of the towering Mora. Its topmost branch, when naked with age or dried by accident, is the favourite resort of the Toucan. Many a time has this singular bird felt the shot faintly strike him from the gun of the fowler beneath, and owed his life to the distance betwixt them.

The trees which form these far-extending wilds are as useful as they are ornamental. It would take a volume of itself to describe them.

The Green-heart, famous for its hardness and durability; the Hackea, for its toughness; the Ducalabali, surpassing mahogany; the Ebony and Letter-wood, vying with the choicest woods of the old world; the Locust-tree, yielding copal; and the Hayawa and Olou-trees, furnishing a sweet- 
smelling resin, are all to be met with in the forest, betwixt the plantations and the rock Saba.

Beyond this rock the country has been little explored; but it is very probable that these, and a vast collection of other kinds, and possibly many new species, are scattered up and down, in all directions, through the swamps, and hills, and savannas of ci-devant Dutch Guiana.

On viewing the stately trees around him the naturalist will observe many of them bearing leaves, and blossoms, and fruit, not their own.

The Wild Fig-tree, as large as a common English apple-tree, often rears itself from one of the thick branches at the top of the mora; and when its fruit is ripe, to it the birds resort for nourishment. It was to an undigested seed, passing through the body of the bird which had perched on the mora, that the fig-tree first owed its elevated station there. The sap of the mora raised it into full bearing; but now, in its turn, it is doomed to contribute a portion of its own sap and juices towards the growth of a different species of vines, the seeds of which, also, the birds deposited on its branches. These soon vegetate, and bear fruit in great quantities; so what with their nsurpation of the resources of the fig-tree, and the fig-tree of the mora, the mora, unable to support a charge which nature never intended it should, languishes and dies under its burden; and then the fig-tree, and its usurping progeny of vines, receiving no more succour from their late fosterparent, droop and perish in their turn.

A vine, called the Bush-rope by the woodcutters, on account of its use in hauling out the 


\section{WANDERINGS IN SOUTH AMERICA}

heariest timber, lias a singular appearance in the forests of Demerara. Sometimes you see it nearly as thick as a man's body, twisted like a corkscrew round the tallest trees, and rearing its head high above their tops. At other times three or four of them, like strands in a cable, join tree and tree and branch and branch together. Others, descending from on high, take root as soon as their extremity tonches the ground, and appear like shronds and stays supporting the mainmast of a line-of-battle ship; while others, sending out parallel, oblique, horizontal, and perpendicular shoots in all directions, put you in mind of what travellers call a matted forest. Oftentimes a tree, above a hundred feet high, uprooted by the whirlwind, is stopped in its fall by these amazing cables of nature; and hence it is that you account for the phenomenon of seeing trees not only vegetating, but sending forth vigorous shoots, though far from their perpendicular, and their trunks inclined to every degree from the meridian to the liorizon.

Their heads remain firmly supported by the bush-rope; many of their roots soon refix themselves in the earth, and frequently a strong shont will sprout out perpendicularly from near the root of the reclined trunk, and in time become a fine tree. No grass grows under the trees; and few weeds, except in the swamps.

The high grounds are pretty clear of underwood, and with a cutlass to sever the small bushropes, it is not difficult walking among the trees.

The soil, chiefly formed by the fallen leaves and decayed trees, is very rich and fertile in the valleys. On the hills, it is little better than sand. 


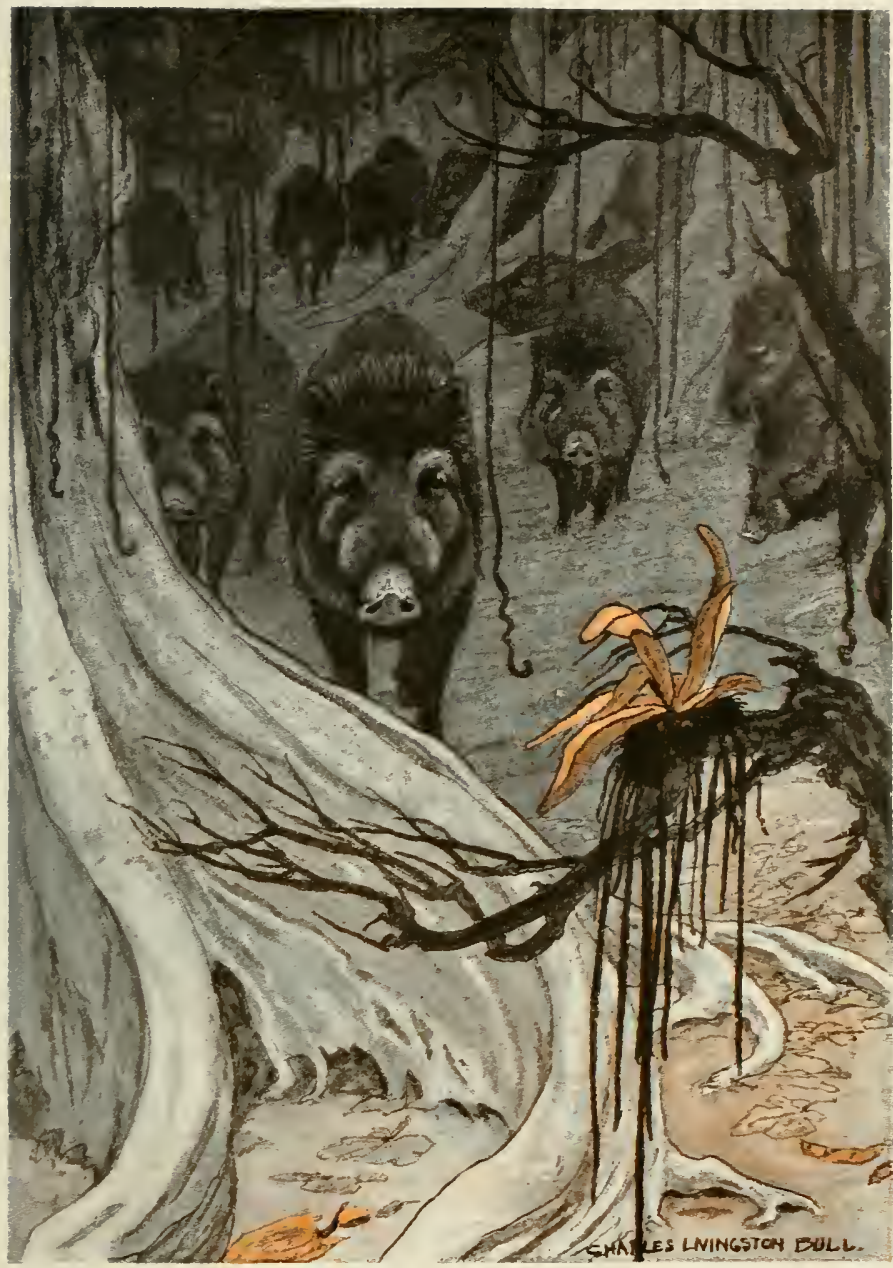

"The Peccari herd together, and traverse the wills in all "lirections", 

The rains seem to have carried away, and swept into the valleys, every particle which nature intended to have formed a mould.

Four-footed animals are scarce, considering how very thinly these forests are inhabited by men.

-Several species of the animal, commonly called Tiger, though in reality it approaches nearer to the leopard, are found here; and two of their diminutives, named Tiger-cats. The Tapir, the Labba, and Deer, afford excellent food, and chiefly frequent the swamps and low ground, near the sides of the river and creeks.

In stating that four-footed animals are scarce, the Peccari must be excepted. Three or four hundred of them herd together, and traverse the wilds in all directions, in quest of roots and fallen seeds. The Indians mostly shoot them with poisoned arrows. When wounded, they run about one hundred and fifty paces; they then drop, and make wholesome food.

The Red Monkey, erroneously called the baboon, is heard oftener than it is seen; while the common Brown Monkey, the Bisa, and Sacawinki, rove from tree to tree, and amuse the stranger as he journeys on.

A species of the Polecat, and another of the Fox, are destructive to the Indian's poultry; while the Opossum, the Guana, and Salempenta, afford him a delicious morsel.

The small Ant-bear, and the large one, remarkable for his long, broad, bushy tail, are sometimes seen on the tops of the wood-ants' nests; the Armadillos bore in the sand-hills, like rabbits in 
a warren; and the Porcupine is now and then discovered in the trees over your head.

This, too, is the native country of the Sloth. His looks, his gestures, and his cries, all conspire to entreat you to take pity on him. These are the only weapons of defence which nature hath given him. While other animals assemble in herds, or in pairs range through these boundless wilds, the sloth is solitary, and almost stationary; he cannot escape from you. It is said, his piteous moans make the tiger relent, and turn out of the way. Do not then level your gun at him, or pierce him with a poisoned arrow;-he has never hurt one living creature. A few leaves, and those of the commonest and coarsest kind, are all he asks for his support. On comparing him with other animals, you would say that you could perceive deficiency, deformity, and superabundance in his composition. He has no cutting teeth, and though four stomachs, he still wants the long intestines of ruminating animals. He has only one inferior aperture, as in birds. He has no soles to his feet, nor has he the power of moving his toes separately. His hair is flat, and puts you in mind of grass withered by the wintry blast. His legs are too short; they appear deformed by the manner in which they are joined to the body; and when he is on the ground, they seem as if only calculated to be of use in climbing trees. He has forty-six ribs, while the elephant has only forty; and his claws are disproportionably long. Were you to mark down, upon a graduated scale, the different claims to superiority amongst the four-footed 
animals, this poor, ill-formed creature's claim would be the last upon the lowest degree.

Demerara yields to no country in the world in her wonderful and beautiful productions of the feathered race. Here the finest precious stones are far surpassed by the vivid tints which adorn the birds. The naturalist may exclaim, that nature has not known where to stop in forming new species, and painting her requisite shades. Almost every one of those singular and elegant birds described by Buffon as belonging to Cayenne, are to be met with in Demerara; but it is only by an indefatigable naturalist that they are to be found.

The Scarlet Curlew breeds in innumerable quantities in the muddy islands on the coasts of Pomauron; the Egrets and Crabiers in the same place. They resort to the mud-flats at ebbing water, while thousands of Sandpipers and Plovers, with here and there a Spoonbill and Flamingo, are seen amongst them. The Pelicans go farther out to sea, but return at sundown to the Couradatrees. The Humming-birds are chiefly to be found near the flowers at which each of the species of the genus is wont to feed. The pie, the gallinaceous, the columbine, and passerine tribes, resort to the fruit-bearing trees.

You never fail to see the common Vulture where there is carrion. In passing up the river there was an opportunity of seeing a pair of the King of the Vultures; they were sitting on the naked branch of a tree, with about a dozen of the common ones with them. A Tiger had killed a Goat the day before; he had been driven away in the act of sucking the blood, and not finding it safe 
or prudent to return, the goat remained in the same place where he had killed it; it had begun to putrefy, and the vultures had arrived that morning to claim the savoury morsel.

At the close of day, the Vampires leave the hollow trees, whither they had fled at the morning's dawn, and scour along the river's banks in quest of prey. On waking from sleep, the astonished traveller finds his hammock all stained with blood. It is the vampire that hath sucked him. Not man alone, but every umprotected animal, is exposed to his depredations: and so gently does this nocturnal surgeon draw the blood, that instead of being roused, the patient is lulled into a still profounder sleep. There are two species of vampire in Demerara, and both suck living animals; one is rather larger than the common bat; the other measures above two feet from wing to wing extended.

Snakes are frequently met with in the woods betwixt the sea-coast and the rock Saba, chiefly near the creeks and on the banks of the river. They are large, beautiful, and formidable. The Rattlesnake seems partial to a tract of ground known by the name of Canal Number-three; there the effects of lis poison will be long remembered. The Camoudi snake has been killed from thirty to forty feet long; though not venomous, his size renders him destructive to the passing animals. The Spaniards in the Oroonoque positively affirm that he grows to the length of seventy or eighty feet, and that he will destroy the strongest and largest bull. Tis name seems to confirm this; there he is called "matatoro," which literally 
means "bull-killer." Thus he may be ranked amongst the deadly snakes; for it comes nearly to the same thing in the end, whether the victim dies by poison from the fangs, which corrupts his blood and makes it stink horribly, or whether his body be crushed to mummy, and swallowed by this hideous beast.

The Whipsnake, of a beautiful changing green, and the Coral, with alternate broad transverse bar's of black and red, glide from bush to bush, and may be handled with safety; they are harmless little creatures.

The Labarri snake is speckled, of a dirty brown colour, and can scarcely be distinguished from the ground or stump on which he is coiled up; he grows to the length of about eight feet, and his bite often proves fatal in a few minutes.

Unrivalled in his display of every lovely colour of the rainbow, and ummatched in the effects of his deadly poison, the Couanaconchi glides undaunted on, sole monarch of these forests; he is commonly known by the name of the bush-master. Both man and beast fly before him, and allow him to pursue an undisputed path. He sometimes grows to the length of fourteen feet.

A few small Caimen, from two to twelve feet long, may be observed now and then in passing up and down the river; they just keep their heads above the water, and a stranger would not know them from a rotten stump.

Lizards of the finest green, brown, and copper colour, from two inches to two feet and a half long, are ever and anon rustling among the fallen leaves, and crossing the path before you; whilst 
the Chameleon is busily employed in chasing insects round the trunks of the neighbouring trees.

The fish are of many different sorts, and welltasted, but not, generally speaking, very plentiful. It is probable that their numbers are considerably thinned by the Otter's, which are much larger than those of Europe. In going through the overflowed savannas, which have all a communication with the river, you may often see a dozen or two of them sporting amongst the sedges before you.

This warm and humid climate seems particularly adapted to the producing of insects; it gives birth to myriads, beautiful past description in their variety of tints, astonishing in their form and size, and many of them noxious in their qualities.

He whose eye can distinguish the various beauties of uncultivated nature, and whose ear is not shut to the wild sounds in the woods, will be delighted in passing up the river Demerara. Every now and then, the Maam or Tinamou sends forth one long and plaintive whistle from the depths of the forest, and then stops; whilst the yelping of the Toucan, and the shrill voice of the bird called Pi-pi-yo, is heard during the interval. The Campanero never fails to attract the attention of the passenger: at a distance of nearly three miles, you may hear this snow-white bird tolling every four or five minutes, like the distant convent bell. From six to nine in the morning, the forests resound with the mingled cries and strains of the feathered race; after this, they gradually die away. From eleven to three all nature is hushed as in a midnight silence, and scarce a note is heard, 
saving that of the campanero and the pi-pi-yo; it is then that, oppressed by the solar heat, the birds retire to the thickest shade, and wait for the refreshing cool of evening.

At sundown the Vampires, Bats, and Goatsuckers dart from their lonely retreat, and skim along the trees on the river's bank. The different kinds of Frogs almost stun the ear with their coarse and hollow-sounding croaking, while the Owls and goat-suckers lament and mourn all night long.

About two hours before daybreak, you will hear the red monkey moaning as though in deep distress; the Houtou, a solitary bird, and only found in the thickest recesses of the forest, distinctly articulates, "houtou, houtou," in a low and plaintive tone, an hour before sunrise; the maam whistles about the same hour; the Hannaquoi, Pataca, and Maroudi announce his near approach to the eastern horizon, and the Parrots and Paroquets confirm his arrival there.

The Crickets chirp from sunset to sunrise, and often during the day, when the weather is cloudy. The Bête-rouge is exceedingly numerous in these extensive wilds, and not only man, but beasts and birds, are tormented by it. Mosquitos are very rare after you pass the third island in the Demerara, and Sand-flies but seldom appear.

Courteous reader, here thou hast the outlines of an amazing landscape given thee; thou wilt see that the principal parts of it are but faintly traced, some of them scarcely visible at all, and that the shades are wholly wanting. If thy soul partakes of the ardent flame which the persevering 
Mungo Park's did, these outlines will be enough for thee: they will give thee some idea of what a noble country this is; and if thou hast but courage to set about giving the world a finished picture of it, neither materials to work on, nor colours to paint it in its true shades, will be wanting to thee. It may appear a difficult task at a distance; but look close at it, and it is nothing at all ; provided thou hast but a quiet mind, little more is necessary, and the genius which presides over these wilds will kindly help thee through the rest. She will allow thee to slay the fawn, and cut down the Mountain-cabbage for thy support, and to select from every part of her domain whatever may be necessary for the work thou art about; but having killed a pair of Doves in order to enable thee to give mankind a true and proper description of them, thou must not destroy a third through wantonness, or to show what a good marksman thou art; that would only blot the picture thou art finishing, not colour it.

Though retired from the haunts of men, and even without a friend with thee, thon wouldst not find it solitary. The crowing of the Hamnaquoi will sound in thine ears like the daybreak townclock; and the Wren and the Thrush will join with thee in thy matin hymn to thy Creator, to thank Him for thy night's rest.

At noon thy Genius will lead thee to the Troely, one leaf of which will defend thee from both sun and rain. And if, in the cool of the evening, thou hast been tempted to stray too far from thy place of abode, and art deprived of light to write down the information thou hast collected, the Firefly, 
which thon wilt see in almost every bush around thee, will be thy candle. Hold it over thy pocket book, in any position which thou knowest will not hurt it, and it will afford thee ample light. And when thou hast done with it, put it kindly back again on the next branch to thee. It will want no other reward for its services.

When in thy hammock, should the thought of thy little crosses and disappointments, in thy ups and downs through life, break in upon thee, and throw thee into a pensive mood, the $\mathrm{Owl}$ will bear thee company. She will tell thee that hard has been her fate too; and at intervals, "Whip-poorWill," and "Willy come go," will take up the tale of sorrow. Ovid has told thee how the owl once boasted the human form, and lost it for a very small offence; and were the poet alive now, he would inform thee, that "Whip-poor-Will," and "Willy come go," are the shades of those poor African and Indian slaves, who died worn ont and broken-hearted. They wail and cry, "Whip-poorWill," and "Willy come go," all night long; and often, when the moon shines, you see them sitting on the green turf, near the houses of those whose ancestors tore them from the bosom of their helpless families, which all probably perished through grief and want, after their support was gone.

About an hour above the rock of Saba, stands the habitation of an Indian, called Simon, on the top of a hill. The side next the river is almost perpendicular, and you may easily throw a stone over to the opposite bank. Here there was an opportunity of seeing man in his rudest state. The Indians who frequented this habitation, though 


\section{WANDERINGS IN SOUTH AMERICA}

living in the midst of woods, bore evident marks of attention to their persons. Their hair was neatly collected, and tied up in a knot; their bodies fancifully painted red, and the paint was scented with hayawa. This gave them a gay and animated appearance. Some of them had on necklaces, composed of the teeth of wild boars slain in the chase; many wore rings, and others had an ornament on the left arm, midway betwixt the shoulder and the elbow. At the close of day they regularly bathed in the river below; and the next morning seemed busy in renewing the faded colours of their faces.

One day there came into the hut a form which literally might be called the wild man of the woods. On entering, he laid down a ball of wax, which he had collected in the forest. His hammock was all ragged and torn; and his bow, though of good wood, was without any ornament or polish; "erubuit domino, cultior esse suo." His face was meagre, his looks forbidding, and his whole appearance neglected. His long black hair hung from his head in matted confusion; nor had his body, to all appearance, ever been painted. They gave him some Cassava bread and boiled fish, which he ate voraciously, and soon after left the hut. As he went ont you could observe no traces in his countenance or demeanor, which indicated that he was in the least mindful of having been benefited by the society he was just leaving.

The Indians said that he had neither wife, nor child, nor friend. They had often tried to persuade him to come and live amongst them; but it 
was of no avail. He went roving on, plundering the Wild Bees of their honey, and picking up the fallen nuts and fruits of the forest. When he fell in with game, he procured fire from two sticks, and cooked it on the spot. When a hut happened to be in his way, he stepped in, and asked for something to eat, and then months elapsed ere they saw him again. They did not know what had caused him to be thus unsettled; he had been so for years; nor did they believe that even old age itself would change the habits of this poor, harmless, solitary wanderer.

From Simon's, the traveller may reach the large fall, with ease, in four days.

The first falls that he meets are merely rapids, scarce a stone appearing above the water in the rainy season; and those in the bed of the river, barely high enough to arrest the water's course, and by causing a bubbling, show that they are there.

With this small change of appearance in the stream, the stranger observes nothing new till he comes within eight or ten miles of the great fall. Each side of the river presents an uninterrupted range of wood, just as it did below. All the productions found betwixt the plantations and the rock Saba, are to be met with here.

From Simon's to the great fall there are five habitations of the Indians-two of them close to the river's side; the other three a little way in the forest. These habitations consist of from four to eight huts, situated on about an acre of ground which they have cleared from the surrounding 
woods. A few Pappaw, Cotton, and mountain cabbage-trees, are scattered round them.

At one of these habitations a small quantity of the Wourali-poison was procured. It was in a little gourd. The Indian who had it said that he had killed a number of Wild Hogs with it, and two Tapirs. Appearances seemed to confirm what he said; for on one side it had been nearly taken out to the bottom, at different times, which probably would not have been the case had the first or second trial failed.

Its strength was proved on a middle-sized dog. He was wounded in the thigh, in order that there might be no possibility of touching a vital part. In three or four minutes he began to be affected, smelt at every little thing on the ground around him, and looked wistfully at the wounded part. Soon after this he staggered, laid himself down, and never rose more. He barked once, though not as if in pain. His voice was low and weak; and in a second attempt it quite failed him. He now put his head betwixt his fore-legs, and raising it slowly again, he fell over on his side. His eye immediately became fixed, and though his extremities every now and then shot convulsively, he never showed the least desire to raise up his head. His heart fluttered much from the time he lay down, and at intervals beat very strong; then stopped for a moment or two, and then beat again; and continued faintly beating several minutes after every other part of his body seemed dead.

In a quarter of an hour after he had received the poison he was quite motionless. 
A few miles before you reach the great fall, and which, indeed, is the only one which can be called a fall, large balls of froth come floating past you. The river appears beautifully marked with streaks of foam, and on your nearer approach the stream is whitened all over.

At first, you behold the fall rushing down a bed of rocks, with a tremendous noise, divided into two foamy streams, which at their junction again form a small island covered with wood. Above this island, for a short space, there appears but one stream, all white with froth, and fretting and boiling amongst the huge rocks which obstruct its course.

Higher up it is seen dividing itself into a short channel or two, and trees grow on the rocks which caused its separation. The torrent in many places has eaten deep into the rocks, and split them into large fragments by driving others against them. The trees on the rocks are in bloom and vigour, though their roots are half bared, and many of them bruised and broken by the rushing waters.

This is the general appearance of the fall from the level of the water below to where the river is smooth and quiet above. It must be remembered that this is during the periodical rains. Probably in the dry season it puts on a very different appearance. There is no perpendicular fall of water of any consequence throughout it, but the dreadful roaring and rushing of the torrent down a long, rocky, and moderately sloping channel, has a fine effect; and the stranger returns well pleased with what he has seen. No animal, nor craft of 
any kind, could stem this downward flood. In a few moments the first would be killed, the second dashed in pieces.

The Indians have a path alongside of it, through the forest, where prodigious Crabwood-trees grow. Up this path they drag their canoes, and launch them into the river above; and on their return bring them down the same way.

About two hours below this fall is the habitation of an Acoway chief called Sinkerman. At night you hear the roaring of the fall from it. It is pleasantly situated on the top of a sand-hill. At this place you have the finest view the river Demerara affords: three tiers of hills rise in slow gradation, one above the other, before you, and present a grand and magnificent scene, especially to him who has been accustomed to a level country.

Here, a little after midnight on the first of May, was heard a most strange and unaccountable noise; it seemed as though several regiments were engaged, and musketry firing with great rapidity. The Indians, terrified beyond description, left their hammocks, and crowded all together, like sheep at the approach of the wolf. There were no soldiers within three or four hundred miles. Conjecture was of no avail, and all conversation next morning on the subject was as useless and unsatisfactory as the dead silence which succeeded to the noise.

He who wishes to reach the Macoushi country had better send his canoe over land from Sinkerman's to the Essequibo.

There is a pretty good path, and meeting a 
creek about three-quarters of the way, it eases the labour, and twelve Indians will arrive with it in the Essequibo in four days.

The traveller need not attend his canoe; there is a shorter and a better way. Half an hour below Sinkerman's he finds a little creek on the western bank of the Demerara. After proceeding about a couple of hundred yards up it, he leaves it, and pursues a west-north-west direction by land for the Essequibo. The path is good, though somewhat rugged with the roots of trees, and here and there obstructed by fallen ones; it extends more over level ground than otherwise. There are a few steep ascents and descents in it, with a little brook running at the bottom of them; but they are easily passed over, and the fallen trees serve for a bridge.

You may reach the Essequibo with ease in a day and a half; and so matted and interwoven are the tops of the trees above you that the sun is not felt once all the way, saving where the space which a newly-fallen tree occupied lets in his rays upon you. The forest contains an abundance of Wild Hogs, Labbas, Acouries, Powisses, Maams, Maroudis, and Waracabas, for your nourishment, and there are plenty of leaves to cover a shed whenever you are inclined to sleep.

The soil has three-fourths of sand in it, till you come within half an hour's walk of the Essequibo, where you find a red gravel and rocks. In this retired and solitary tract, nature's garb, to all appearance, has not been injured by fire, nor her productions broken in upon by the exterminating hand of man. 
Here the finest Green-heart grows, and Wallaba, Purple-heart, Siloabali, Sawari, Buletre, Tauronira, and Mora, are met with in vast abumdance, far and near, towering up in majestic grandeur, straight as pillars, sixty or seventy feet high, without a knot or branch.

Traveller, forget for a little while the idea thou hast of wandering farther on, and stop and look at this grand picture of vegetable nature; it is a reflection of the crowd thou hast lately been in, and though a silent monitor, it is not a less eloquent one on that account. See that noble Purple-heart before thee! Nature has been kind to it. Not a hole, not the least oozing from its trunk, to show that its best days are past. Vigorous in youthful blooming beauty, it stands the ornament of these sequestered wilds, and tacitly rebukes those base ones of thine own species who have been hardy enough to deny the existence of Him who ordered it to flourish here.

Behold that one next to it!-Hark! how the hammerings of the Red-headed Woodpecker resound throngh its distempered boughs! See what a quantity of holes he has made in it, and how its bark is stained with the drops which trickle down from them. The lightning, too, has blasted one side of it. Nature looks pale and wan in its leaves, and her resources are nearly dried up in its extremities; its sap is tainted; a mortal sickness, slow as a consumption, and as sure in its consequences, has long since entered its frame, vitiating and destroying the wholesome juices there.

Step a few paces aside, and cast thine eye on that remnant of a Mora behind it. Best part of its 
branches, once so high and ornamental, now lie on the ground in sad confusion one upon the other, all shattered and fungus-grown, and a prey to millions of insects, which are busily employed in destroying them. One branch of it still looks healthy! Will it recover? No, it cannot; nature has already run her course, and that healthy-looking branch is only as a fallacious good symptom in him who is just about to die of a mortification when he feels no more pain, and fancies his distemper has left him; it is as the momentary gleam of a wintry sun's ray close to the western horizon. -See! while we are speaking, a gust of wind has brought the tree to the ground, and made room for its successor.

Come further on, and examine that apparently luxuriant Tanronira on thy right hand. It boasts a verdure not its own; they are false ornaments it wears; the Bush-rope and Bird-vines have clothed it from the root to its topmost branch. The succession of fruit which it hath borne, like good cheer in the houses of the great, has invited the birds to resort to it, and they have disseminated beautiful, though destructive, plants on its branches, which, like the distempers vice brings into the human frame, rob it of all its health and vigour; they have shortened its days, and probably in another year they will finally kill it, long before nature intended that it should die.

Ere thou leavest this interesting scene, look on the ground around thee, and see what everything here below must come to.

Behold that newly fallen Wallaba! The whirlwind has uprooted it in its prime, and it has 
brought down to the ground a dozen small ones in its fall. Its bark has already begun to drop off! And that heart of Mora elose by it is fast yielding, in spite of its firm, tough texture.

The tree which thou passedst but a little ago, and which perhaps has lain over yonder brook for years, can now hardly support itself, and in a few months more it will have fallen into the water.

Put thy foot on that large trunk thou seest to the left. It seems entire amid the surrounding fragments. Mere outward appearance, delusive phantom of what it once was! Tread on it, and like the fuss-ball, it will break into dust.

Sad and silent mementos to the giddy traveller as he wanders on! Prostrate remnants of vegetable nature, how incontestably ye prove what we must all at last come to, and how plain your mouldering ruins show that the firmest texture avails us nought when Heaven wills that we should cease to be! -

"The cloud-capt towers, the gorgeous palaces,

The solemn temples, the great globe itself,

Yea, all which it inhabit, shall dissolve,

And, like the baseless fabric of a vision,

Leave not a wrack behind." "*

Cast thine eye around thee, and see the thousands of nature's productions. Take a view of them from the opening seed on the surface, sending a downward shoot, to the loftiest and the largest trees, rising up and blooming in wild luxuriance; some side by side, others separate; some curved and knotty, others straight as lanees; all, in beautiful gradation, fulfilling the mandates they had received from Heaven, and though con-

${ }^{*} \mathrm{~A}$ curious misquotation of the author's. See The Tempost, Act IV, Sc. I. 
demned to die, still never failing to keep up their species till time shall be no more.

Reader, canst thou not be induced to dedicate a few months to the good of the public, and examine with thy scientific eye the productions which the vast and well-stored colony of Demerara presents to thee?

What an immense range of forest is there from the rock Saba to the great fall! and what an uninterrupted extent before thee from it to the banks of the Essequibo! No doubt, there is many a balsam and many a medicinal root yet to be discovered, and many a resin, gum, and oil yet unnoticed. Thy work would be a pleasing one, and thou mightest make several useful observations in it.

Would it be thought impertinent in thee to hazard a conjecture, that with the resources the government of Demerara has, stones might be conveyed from the rock Saba to Stabroek, to stem the equinoctial tides, which are for ever sweeping away the expensive wooden piles round the mounds of the fort? Or would the timber-merchant point at thee in passing by, and call thee a descendant of La Mancha's knight, because thou maintainest that the stones which form the rapids might be removed with little expense, and thus open the navigation to the wood-cutter from Stabroek to the great fall? Or wouldst thou be deemed enthusiastic or biassed, because thou givest it as thy opinion that the climate in these high lands is exceedingly wholesome, and the lands themselves capable of nourishing and maintaining any number of settlers? In thy disser- 


\section{WANDERINGS IN SOUTH AMERICA}

tation on the Indians, thou mightest hint, that possibly they could be induced to help the new settlers a little; and that finding their labours well requited, it would be the means of their keeping up a constant communication with us, which probably might be the means of laying the first stone towards their Christianity. They are a poor, harmless, inoffensive set of people, and their wandering and ill-provided way of living seems more to ask for pity from us, than to fill our heads with thoughts that they would be hostile to us.

What a noble field, kind reader, for thy experimental philosophy and speculations, for thy learning, for thy perseverance, for thy kind-heartedness, for everything that is great and good within thee!

The accidental traveller who has journeyed on from Stabroek to the rock Saba, and from thence to the banks of the Essequibo, in pursuit of other things, as he told thee at the begimning, with but an indifferent interpreter to talk to, no friend to converse with, and totally unfit for that which he wishes thee to do, can merely mark the outlines of the path he has trodden, or tell thee the sounds he has heard, or faintly describe what he has seen in the environs of his resting-places; but if this be enough to induce thee to undertake the journey, and give the world a description of it, he will be amply satisfied.

It will be two days and a half from the time of entering the path on the western bank of the Demerara till all be ready, and the canoe fairly afloat on the Essequibo. The new rigging it, and put- 
ting every little thing to rights and in its proper place, cannot well be done in less than a day.

After being night and day in the forest impervious to the sun's and moon's rays the sudden transition to light has a fine heart-cheering effect. Welcome as a lost friend, the solar beam makes the frame rejoice, and with it a thousand enlivening thoughts rush at once on the soul, and disperse, as a vapour, every sad and sorrowful idea which the deep gloom had helped to collect there. In coming out of the woods, you see the western bank of the Essequibo before you, low and flat. Here the river is two-thirds as broad as the Demerara at Stabroek.

To the northward there is a hill higher than any in the Demerara; and in the south-south-west quarter a mountain. It is far away, and appears like a bluish clond in the horizon. There is not the least opening on either side. Hills, valleys, and lowlands, are all linked together by a chain of forest. Ascend the highest mountain, climb the loftiest tree, as far as the eye can extend, whichever way it directs itself, all is luxuriant and unbroken forest.

In about nime or ten hours from this, you get to an Indian habitation of three huts, on the point of an island. It is said that a Dutch post once stood here. But there is not the smallest vestige of it remaining, and, except that the trees appear younger than those on the other islands, which shows that the place has been cleared some time or other, there is no mark left by which you can conjecture that ever this was a post.

The many islands which you meet with in the 
way, enliven and change the scene, by the avenues which they make, which look like the mouths of other rivers, and break that long-extended sameness which is seen in the Demerara.

Proceeding onwards, you get to the falls and rapids. In the rainy season they are very tedious to pass, and often stop your course. In the dry season, by stepping from rock to rock, the Indians soon manage to get a canoe over them. But when the river is swollen, as it was in May, 1812, it is then a difficult task, and often a dangerous one too. At that time many of the islands were overflowed, the rocks covered, and the lower branches of the trees in the water. Sometimes the Indians were obliged to take everything out of the canoe, cut a passage through the branches, which hung over into the river, and then drag up the canoe by main force.

At one place, the falls form an oblique line quite across the river, impassable to the ascending canoe, and you are forced to have it dragged four or five hundred yards by land.

It will take you five days, from the Indian habitation, on the point of the island, to where these falls and rapids terminate.

There are no huts in the way. You must bring your own cassava-bread along with you, hunt in. the forest for your meat, and make the night's shelter for yourself.

Here is a noble range of hills, all covered with the finest trees, rising majestically one above the other, on the western bank, and presenting as rich a scene as ever the eye would wish to look on. 
Nothing in vegetable nature can be conceived more charming, grand, and luxuriant.

How the heart rejoices in viewing this beautiful landscape! when the sky is serene, the air cool, and the sun just sunk behind the mountain's top.

The Hayawa-tree perfumes the woods around; pairs of Scarlet Aras are continually crossing the river. The Maam sends forth its plaintive note, the Wren chants its evening song. The Caprimulgus wheels in busy flight around the canoe, while "Whip-poor-Will" sits on the broken stump near the water's edge, complaining as the shades of night set in.

A little before you pass the last of these rapids two immense rocks appear, nearly on the summit of one of the many hills which form this far-extending range, where it begins to fall off gradually to the south.

They look like two ancient stately towers of some Gothic potentate, rearing their heads above the surrounding trees. What with their situation and their shape together, they strike the beholder with an idea of antiquated grandeur which he will never forget. He may travel far and near and see nothing like them. On looking at them through a glass, the summit of the southern one appeared crowned with bushes. The one to the north was quite bare. The Indians have it from their ancestors that they are the abode of an evil genius, and they pass in the river below with a reverential awe.

In about seven hours from these stupendous sons of the hill, you leave the Essequibo, and enter the river Apourapoura, which falls into it from the 
south. The Apourapoura is nearly one-third the size of the Demerara at Stabroek. For two days you see nothing but level ground, richly clothed in timber. You leave the Siparouni to the right hand, and on the third day come to a little hill. The Indians have cleared about an acre of ground on it, and erected a temporary shed. If it be not intended for provision-ground alone, perhaps the next white man who travels through these remote wilds will find an Indian settlement here.

Two days after leaving this, you get to a rising ground on the western bank, where stands a single hut; and about half a mile in the forest there are a few more; some of them square, and some round with spiral roofs.

Here the fish called Pacou is very plentiful: it is perhaps the fattest and most delicious fish in Guiana. It does not take the hook, but the Indians decoy it to the surface of the water by means of the seeds of the Crabwood-tree, and then shoot it with an arrow.

You are now within the borders of Macoushia, inhabited by a different tribe of people, called Macoushi Indians; uncommonly dexterous in the use of the blow-pipe, and famous for their skill in preparing the deadly vegetable poison, commonly called Wourali.

It is from this country that those beautiful paroquets named Kessi-kessi are procured. Here the erystal mountains are found; and here the three different species of the Ara are seen in great abundance. Here, too, grows the tree from which the gum-elastic is got: it is large, and as tall as 


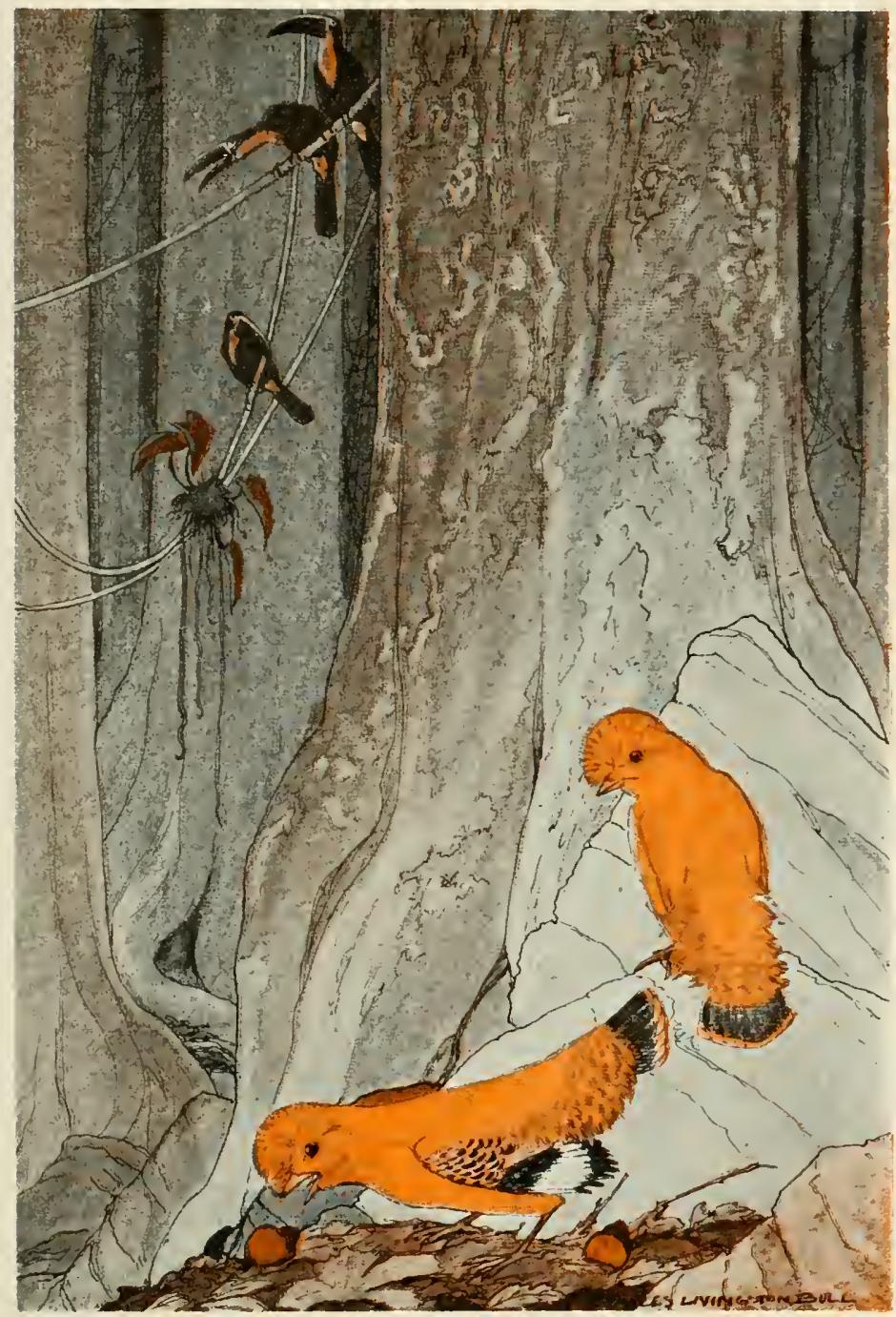

The Cock of the Rock 

any in the forest. The wood has much the appearance of sycamore. The gum is contained in the bark: when that is cut through, it oozes out very freely: it is quite white, and looks as rich as cream: it hardens almost immediately as it issues from the tree; so that it is very easy to collect a ball, by forming the juice into a globular shape as fast as it comes out: it becomes nearly black by being exposed to the air, and is real India-rubber without undergoing any process.

The elegant crested bird called Cock of the Rock, admirably described by Buffon, is a native of the woody mountains of Macoushia. In the daytime, he retires amongst the darkest rocks, and only comes out to feed a little before sunrise, and at sunset: he is of a gloomy disposition, and, like the Houtou, never associates with the other birds of the forest.

The Indians, in the just-mentioned settlement, seemed to depend more on the wourali-poison for killing their game than upon anything else. They had only one gun, and it appeared rusty and neglected; but their poisoned weapons were in fine order. Their blow-pipes hung from the roof of the hut, carefully suspended by a silk-grass cord; and on taking a nearer view of them, no dust seemed to have collected there, nor had the spider spun the smallest web on them; which showed that they were in constant use. The quivers were close by them, with the jaw-bone of the fish Pirai tied by a string to their brim, and a small wickerbasket of wild cotton, which hung down to the centre; they were nearly full of poisoned arrows. It was with difficulty these Indians could be per- 
suaded to part with any of the wourali-poison, though a good price was offered for it; they gave me to understand that it was powder and shot to them, and very difficult to be procured.

On the second day after leaving the settlement, in passing along, the Indians show you a place where once a white man lived. His retiring so far from those of his own colour and acquaintance seemed to carry something extraordinary along with it, and raised a desire to know what could have induced him to do so. It seems he had been unsuccessful, and that his creditors had treated him with as little mercy as the strong generally show to the weak. Seeing his endeavours daily frustrated, and his best intentions of no avail, and fearing that when they had taken all he had they would probably take his liberty too, he thought the world would not be hard-hearted enough to condemn him for retiring from the evils which pressed so heavily on him, and which he had done all that an honest man could do to ward off. $\mathrm{He}$ left his creditors to talk of him as they thought fit, and, bidding adieu forever to the place in which he had once seen better times, he penetrated thus far into those remote and gloomy wilds, and ended his days here.

According to the new map of South America, Lake Parima, or the White Sea, ought to be within three or four days' walk from this place. On asking the Indians whether there was such a place or not, and describing that the water was fresh and good to drink, an old Indian, who appeared to be about sixty, said that there was such a place, and that he had been there. This information would 
have been satisfactory in some degree, had not the Indians carried the point a little too far. It is very large, said another Indian, and ships come to it. Now these unfortunate ships were the very things which were not wanted: had he kept them out, it might have done, but his introducing them was sadly against the lake. Thus you must either suppose that the old savage and his companion had a confused idea of the thing, and that probably the Lake Parima they talked of was the Amazons, not far from the city of Para, or that it was their intention to deceive you. You ought to be cautious in giving credit to their stories, otherwise you will be apt to be led astray.

Many a ridiculous thing concerning the interior of Guiana has been propagated and received as true, merely because six or seven Indians, questioned separately, have agreed in their narrative.

Ask those who live high up in the Demerara, and they will, every one of them, tell you that there is a nation of Indians with long tails; that they are very malicious, cruel, and ill-natured; and that the Portuguese have been obliged to stop them off in a certain river, to prevent their depredations. They have also dreadful stories concerning a horrible beast, called the Watermamma, which, when it happens to take a spite against a canoe, rises out of the river, and in the most unrelenting manner possible carries both canoe and Indians down to the bottom with it, and there destroys them. Ludicrous extravagances; pleasing to those fond of the marvellous, and excellent matter for a distempered brain.

The misinformed and timid court of policy in 
Demerara was made the dupe of a savage, who came down the Essequibo, and gave himself out as king of a mighty tribe. This naked wild man of the woods seemed to hold the said court in tolerable contempt, and demanded immense supplies, all which he got; and moreover, some time after, an invitation to come down the ensuing year for more, which he took care not to forget.

This noisy chieftain boasted so much of his dynasty and domain, that the government was induced to send up an expedition into his territories to see if he had spoken the truth, and nothing but the truth. It appeared, however, that his palace was nothing but a hut, the monarch a needy savage, the heir-apparent nothing to inherit but his father's club, and bow and arrows, and his officers of state wild and uncultivated as the forests through which they strayed.

There was nothing in the hut of this savage, saving the presents he had received from government, but what was barely sufficient to support existence; nothing that indicated a power to collect a hostile force; nothing that showed the least progress towards civilization. All was rude and barbarous in the extreme, expressive of the utmost poverty and a scanty population.

You may travel six or seven days without seeing a hut, and when you reach a settlement it seldom contains more than ten.

The farther you advance into the interior the more you are convinced that it is thinly inhabited.

The day after passing the place where the white man lived you see a creek on the left hand, and shortly after the path to the open country. Here 
you drag the canoe up into the forest, and leave it there. Your baggage must now be carried by the Indians. The creek you passed in the river intersects the path to the next settlement: a large Mora has fallen across it, and makes an excellent bridge. After walking an hour and a half you come to the edge of the forest, and a savanna unfolds itself to the view.

The finest park that England boasts falls far short of this delightful scene. There are about two thousand acres of grass, with here and there a clump of trees, and a few bushes and single trees scattered up and down by the hand of $\mathrm{Na}$ ture. The ground is neither hilly nor level, but diversified with moderate rises and falls, so gently running into one another that the eye cannot distinguish where they begin, nor where they end, while the distant black rocks have the appearance of a herd at rest. Nearly in the middle there is an eminence, which falls off gradually on every side; and on this the Indians have erected their huts.

To the northward of them the foremost forms a circle, as though it had been done by art; to the eastward it hangs in festoons; and to the south and west it rushes in abruptly, disclosing a new scene behind it at every step as you advance along.

This beautiful park of nature is quite surrounded by lofty hills, all arrayed in superbest garb of trees; some in the form of pyramids, others like sugar-loaves towering one above the other, some rounded off, and others as though they had lost their apex. Here two hills rise up 
in spiral summits, and the wooded line of communication betwixt them sinks so gradually that it forms a crescent; and there the ridges of others resemble the waves of an agitated sea. Beyond these appear others, and others past them; and others still farther on, till they can scarcely be distinguished from the clouds.

There are no sand-flies, nor bête-rouge, nor mosquitos, in this pretty spot. The fire-flies during the night vie in numbers and brightness with the stars in the firmament above; the air is pure, and the north-east breeze blows a refreshing gale throughout the day. Here the White-crested Maroudi, which is never found in the Demerara, is pretty plentiful; and here grows the tree which produces the Moran, sometimes called Balsamcapivi.

Your route lies south from this place; and at the extremity of the savanna you enter the forest, and journey along a winding path at the foot of a hill. There is no habitation within this day's walk. The traveller, as usual, must sleep in the forest; the path is not so good the following day. The hills over which it lies are rocky, steep, and rugged, and the spaces betwixt them swampy, and mostly knee-deep in water. After eight hours' walk you find two or three Indian huts, surrounded by the forest; and in little more than half an hour from these you come to ten or twelve others, where you pass the night. They are prettily situated at the entrance into a savanna. The eastern and western hills are still covered with wood; but on looking to the south-west quarter you perceive it begins to die away. In these for- 
ests you may find plenty of the trees which yield the sweet-smelling resin called Acaiari, and which, when pounded and burnt on charcoal, gives a delightful fragrance.

From hence you proceed, in a south-west direction, through a long swampy savanna. Some of the hills which border on it have nothing but a thin coarse grass and huge stones on them; others quite wooded; others with their summits crowned, and their base quite bare; and others, again, with their summits bare, and their base in thickest wood.

Half of this day's march is in water, nearly up to the knees. There are four creeks to pass: one of them has a fallen tree across it. You must make your own bridge across the other three. Probably, were the truth known, these apparently four creeks are only the meanders of one.

The Jabiru, the largest bird in Guiana, feeds in the marshy savanna through which you have just passed. He is wary and shy, and will not allow you to get within gun-shot of him.

You sleep this night in the forest, and reach an Indian settlement about three o'clock the next evening, after walking one-third of the way through wet and miry ground.

But, bad as the walking is through it, it is easier than where you cross over the bare hills, where you have to tread on sharp stones, most of them lying edgewise.

The ground gone over these two last days seems condemned to perpetual solitude and silence. There was not one four-footed animal to be seen, nor even the marks of one. It would have been as 
silent as midnight, and all as still and unmoved as a monument, had not the Jabiru in the marsh, and a few Vultures soaring over the mountain's top, shown that it was not quite deserted by animated nature. There were no insects, except one kind of fly, about one-fourth the size of the common house-fly. It bit cruelly, and was much more tormenting than the mosquito on the sea-coast.

This seems to be the native country of the Arrowroot. Wherever you passed through a patch of wood in a low sitnation, there you found it growing luxuriantly.

The Indian place you are now at is not the proper place to have come to in order to reach the Portuguese frontiers. You have advanced too much to the westward. But there was no alternative. The ground betwixt you and another small settlement (which was the right place to have gone to) was overflowed; and thus, instead of proceeding southward, you were obliged to wind along the foot of the western hills, quite out of your way.

But the grand landscape this place affords makes you ample amends for the time you have spent in reaching it. It would require preat descriptive powers to give a proper idea of the situation these people have chosen for their dwelling.

The hill they are on is steep and high, and full of immense rocks. The huts are not all in one place, but dispersed wherever they have found a place level enough for a lodgement. Before you ascend the hill you see at intervals an acre or two of wood, then an open space, with a few huts on it, then wood again, and then an open space, and so 
on, till the intervening of the western hills, higher and steever still, and crowned with trees of the loreliest shades, closes the enchanting scene.

At the base of this hill stretches an immense plain, which appears to the ere, on this elevated spot, as level as a bowling-green. The mountains on the other side are piled one upon the other in romantic forms, and gradually retire, till they are undiscernible from the clouds in which they are involved. To the south-south-west this far-extending plain is lost in the horizon. The trees on it, which look like islands on the ocean, add greatly to the beauty of the landscape; while the rivulet's course is marked out by the Eta-trees which follow its meanders.

Not being able to pursue the direct course from hence to the next Indian labitation on account of the floods of rrater that fall at this time of the year, you take a circuit westerly along the mountain's foot.

At last a large and deep creek stops your progress : it is wide and rapid, and its banks very steep. There is neither curial nor canoe, nor purple-heart tree in the neighbourhood to make a Wood-skin to carry you over, so that you are obliged to swim across; and by the time you have formed a kind of raft, composed of boughs of tices and coarse grass, to ferry over your baggage, the day will be too far spent to think of proceeding. You must be very cautious before you venture to swim across this creek, for the alligator's are numerous, and near trenty feet long. On the present occasion the Indians took uncommon precautions lest they should be devoured by this 
cruel and voracious reptile. They cut long sticks, and examined closely the side of the creek for half a mile above and below the place where it was to be crossed; and as soon as the boldest had swum over, he did the same on the other side, and then all followed.

After passing the night on the opposite bank, which is well wooded, it is a brisk walk of nine hours before you reach four Indian huts, on a rising ground a few hundred paces from a little brook, whose banks are covered over with Coucourite and Eta-trees.

This is the place you ought to have come to two days ago had the water permitted you. In crossing the plain at the most advantageous place you are above ankle-deep in water for three hours; the remainder of the way is $d r y$, the ground gently rising. As the lower parts of this spacious plain put on somewhat the appearance of a lake during the periodicals rains, it is not improbable but that this is the place which hath given rise to the supposed existence of the famed Lake Parima, or El Dorado; but this is mere conjecture.

A few Deer are feeding on the coarse rough grass of this far-extending plain; they keep at a distance from you, and are continually on the look-out.

The Spur-winged Plover, and a species of the Curlew, black, with a white bar across the wings, nearly as large again as the scarlet curlew on the sea-coast, frequently rise before you. Here, too, the Moscovy Duck is numerous; and large flocks of two other kinds wheel round you as you pass on, but keep out of gun-shot. The milk-white 
Egrets and Jabirus are distinguished at a great distance; and in the rta and coucourite trees you may observe flocks of scarlet and blue Aras feeding on the seeds.

It is to these trees that the largest sort of Toucan resorts. $\mathrm{He}$ is remarkable by a large black spot on the point of his fine yellow bill. He is very scarce in Demerara, and never seen except near the sea-coast.

The ants' nests have a singular appearance on this plain. They are in vast abundance on those parts of it free from water, and are formed of an exceedingly hard yellow clay. They rise eight or ten feet from the ground, in a spiral form, impenetrable to the rain, and strong enough to defy the severest tornado.

The wourali-poison, procured in these last-mentioned huts, seemed very good, and proved afterwards to be very strong.

There are now no more Indian settlements betwixt you and the Portuguese frontiers. If you wish to visit their fort, it would be advisable to send an Indian with a letter from hence, and wait his return. On the present occasion a very fortunate circumstance occurred. The Portuguese commander had sent some Indians and soldiers to build a canoe, not far from this settlement; they had just finished it, and those who did not stay with it had stopped here on their return.

The soldier who commanded the rest, said, he durst not, upon any account, convey a stranger to the fort; but, he added, as there were two canoes, one of them might be despatched with a letter, and then we could proceed slowly on in the other. 
About three hours from this settlement there is a river called Pirarara; and here the soldiers had left their canoes while they were making the new one. From the Pirarara you get into the river Maou, and then into the Tacaton; and just where the Tacatou falls into the Rio Branco, there stands the Portugnese frontier fort, called Fort St. Joachim. From the time of embarking in the river Pirarara, it takes you four days before you reach this fort.

There was nothing very remarkable in passing down these rivers. It is an open country, producing a coarse grass, and interspersed $\pi i$ th climps of trees. The banks have some mood on them, but it appears stunted and crooked, like that on the bleak hills in England.

The Tapir frequently plunged into the river; he was by no means shy, and it was easy to get a shot at him on land. The Kessi-kessi paroquets were in great abundance; and the fine scarlet Aras immumerable in the concourite-trees at a distance from the river's bank. In the Tacaton was seen the Troupiale. It was charming to hear the sweet and plaintive notes of this pretty songster of the wilds. The Portugnese call it the Nightingale of Guiana.

Torrards the close of the fourth evening. the canoe, which had been sent on with a letter, met us with the commander's answer. During its absence, the nights had been cold and stormy, the rain had fallen in torrents, the days cloudy, and there was no sun to dry the wet hammocks. Exposed thus, day and night, to the chilling blast and pelting shower, strength of constitution at last 
failed, and a severe ferer came on. The com. mander's answer was very polite. He remarked, he regretted much to say, that he had received orders to allow no stranger to enter the frontier, and this being the case, he hoped I would not consider him as uncivil: "However," continued he, "I have ordered the soldier to land you at a certain distance from the fort, where we can consult together."

We had now arrived at the place, and the canoe which brought the letter returned to the fort, to tell the commander I had fallen sick.

The sun had not risen above an hour the morning after when the Portuguese officer came to the spot where we had landed the preceding evening. He was tall and spare, and appeared to be from fifty to fifty-five years old; and though thirty years of service under an equatorial sun had burnt and shrivelled up his face, still there was something in it so inexpressibly affable and kind, that it set you immediately at your ease. He came close up to the hammock, and taking hold of my wrist to feel the pulse, "I am sorry, sir," said he, "to see that the ferer has taken such hold of you. You shall go directly with me," continued he, "to the fort; and though we have no doctor there, I trust," added he, "we shall soon bring you about again. The orders I have received forbidding the admission of strangers were never intended to be put in force against a sick English gentleman."

As the canoe was proceeding slowly domn the river towards the fort, the commander asked, with much more interest than a question in ordinary conversation is asked, where was I on the night 
of the first of May? On telling him that I was at an Indian settlement a little below the great fall in the Demerara, and that a strange and sudden noise had alarmed all the Indians, he said the same astonishing noise lad roused every man in Fort St. Joachim, and that they remained under arms till morning. He observed, that he had been quite at a loss to form any idea what could have caused the noise; but now learning that the same noise had been heard at the same time far away from the Rio Branco, it struck him there must have been an earthquake somewhere or other.

Good nourishment and rest, and the unwearied attention and kindness of the Portuguese commander, stopped the progress of the fever, and enabled me to walk about in six days.

Fort St. Joachim was built about five and forty years ago, under the apprehension, it is said, that the Spaniards were coming from the Rio Negro to settle there. It has been much neglected; the floods of water have carried away the gate, and destroyed the wall on each side of it; but the present commander is putting it into thorough repair. When finished, it will mount six nine and six twelve pounders.

In a straight line with the fort, and within a few yards of the river, stand the commander's house, the barracks, the chapel, the father confessor's house, and two others, all at little intervals from each other; and these are the only buildings at Fort St. Joachim. The neighbouring extensive plains afford good pasturage for a fine 


\section{WANDERINGS IN SOUTH AMERICA 73}

breed of cattle, and the Portuguese make enough of butter and cheese for their own consumption.

On asking the old officer if there were such a place as Lake Parima, or El Dorado, he replied, he looked upon it as imaginary altogether. "I have been above forty years," added he, "in Portuguese Guiana, but have never yet met with anybody who has seen the lake."

So much for Lake Parima, or El Dorado, or the White Sea. Its existence at best seems doubtful; some affirm that there is such a place, and others deny it. 


\section{C'HAPTER II}

"Grammatiei certant, et adhuc sub judice lis est."

Having now reached the Portuguese inland frontier, and collected a sufficient quantity of the wourali-poison, nothing remains but to give a brief account of its composition, its effects, its uses, and its supposed antidotes.

It has been already remarked, that in the extensive wilds of Demerara and Essequibo, far away from any European settlement, there is a tribe of Indians who are known by the name of Macoushi.

Though the wourali-poison is used by all the South American savages betwixt the Amazons and the Oroonoque, still this tribe makes it stronger than any of the rest. The Indians in the vicinity of the Rio Negro are aware of this, and come to the Macoushi country to purchase it.

Much has been said concerning this fatal and extraordinary poison. Some have affirmed that its effects are almost instantaneous, provided the minutest particle of it mixes with the blood; and others again have maintained that it is not strong enough to kill an animal of the size and strength of a man. The first have erred by lending a too willing ear to the marvellous, and believing assertions without sufficient proof. The following short 
story points out the necessity of a cautious examination.

One day, on asking an Indian if he thought the poison would kill a man, he replied, that they always go to battle with it; that he was standing by when an Indian was shot with a poisoned arrow, and that he expired almost immediately. Not wishing to dispute this apparently satisfactory information, the subject was dropped. However, about an hour after, having purposely asked him in what part of the body the said Indian was wounded, he answered without hesitation, that the arrow entered betwixt his shoulders, and passed quite through his heart. Was it the weapon, or the strength of the poison, that brought on immediate dissolution in this case? Of course the weapon.

The second have been misled by disappointment, caused by neglect in keeping the poisoned arrows, or by not knowing how to use them, or by trying inferior poison. If the arrows are not kept dry, the poison loses its strength; and in wet or damp weather it turns monldy, and becomes quite soft. In shooting an arrow in this state, upon examining the place where it has entered, it will be observed that, though the arrow has penetrated deep into the flesh, still by far the greatest part of the poison has shrunk back, and thus, instead of entering with the arrow, it has remained collected at the mouth of the wound. In this case the arrow might as rell have not been poisoned. Probably, it was to this that a gentleman, some time ago, owed his disappointment, when he tried the poison on a horse in the town of Stabroek, the 
capital of Demerara; the horse never betrayed the least symptom of being affected by it.

Wishful to obtain the best information concerning this poison, and as repeated inquiries, in lieu of dissipating the surrounding shade, did but tend more and more to darken the little light that existed, I determined to penetrate into the country where the poisonous ingredients grow, where this pernicious composition is prepared, and where it is constantly used. Success attended the adventure; and the information acquired made amends for one hundred and twenty days passed in the solitudes of Guiana, and afforded a balm to the wounds and bruises which every traveller must expect to receive who wanders through a thorny and obstructed path.

Thou must not, courteous reader, expect a dissertation on the manner in which the wouralipoison operates on the system; a treatise has been already written on that subject, and after all, there is probably still reason to doubt. It is supposed to affect the nervous system, and thus destroy the vital functions; it is also said to be perfectly harmless, provided it does not touch the blood. However, this is certain, when a sufficient quantity of it enters the blood, death is the inevitable consequence; but there is no alteration in the colour of the blood, and both the blood and flesh may be eaten with safety.

All that thou wilt find here is a concise, unadorned account of the wourali-poison. It may be of service to thee some time or other, shouldst thou ever travel through the wilds where it is used. Neither attribute to crueltv, nor to a want 
of feeling for the sufferings of the inferior animals, the ensuing experiments. The larger animals were destroyed in order to have proof positive of the strength of a poison which hath hitherto been doubted: and the smaller ones were killed with the hope of substantiating that which has commonly been supposed to be an antidote.

It makes a pitying heart ache to see a poor creature in distress and pain; and too often has the compassionate traveller occasion to heave a sigh as he journeys on. However, here, though the kind-hearted will be sorry to read of an unofrending animal doomed to death, in order to satisfy a doubt, still it will be a relief to know that the victim was not tortured. The wourali-poison destroys life's action so gently, that the victim appears to be in no pain whatever; and probably, were the truth known, it feels none, saving the momentary smart at the time the arrow enters.

A day or two before the Macoushi Indian prepares his poison, he goes into the forest in quest of the ingredients. A vine grows in these wilds, which is called Wourali. It is from this that the poison takes its name, and it is the principal ingredient. When he has procured enough of this, he digs up a root of a very bitter taste, ties them together, and then looks about for two kinds of bulbous plants, which contain a green and glutinous juice. He fills a little quake, which he carries on his back, with the stalks of these; and lastly, ranges up and down till he finds two species of ants. One of them is very large and black, and so venomous, that its sting produces a fever; it is most commonly to be met with on the ground. The 
other is a little red ant, which stings like a nettle, and generally has its nest monder the leaf of a shrub. After obtaining these, he has no more need to range the forest.

A quantity of the strongest Indian pepper is used; but this he has already planted round his hut. The pounded fangs of the Labarri snake, and those of the Counacouchi, are likewise added. These he commonly has in store; for when he kills a snake, he generally extracts the fangs, and keeps them by him.

Having thus found the necessary ingredients, he scrapes the wourali vine and bitter root into thin shavings, and puts them into a kind of colander made of leaves: this he holds over an earthen pot, and pours water on the shavings: the liquor which comes through has the appearance of coffee. When a sufficient quantity has been procured, the shavings are thrown aside. He then bruises the bulbous stalks, and squeezes a proportionate quantity of their juice through his hands into the pot. Lastly, the suakes' fangs, ants, and pepper are bruised, and thrown into it. It is then placed on a slow fire, and as it boils, more of the juice of the wourali is added, according as it may be found necessary, and the scum is taken off with a leaf: it remains on the fire till reduced to a thick syrup of a deep brown colour. As soon as it has arrived at this state, a few arrows are poisoned with it, to try its strength. If it answer the expectations, it is poured out into a calabash, or little pot of Inclian manufacture, which is carefully covered with a couple of leaves, and over them a piece of deer's 
skin, tied round with a cord. They keep it in the most dry part of the hut; and from time to time suspend it over the fire, to counteract the effects of dampness.

The act of preparing this poison is not considered as a common one: the savage may shape his bow, fasten the barb on the point of his arrow, and make his other implements of destruction, either lying in his hammock, or in the midst of his family; but, if he has to prepare the wouralipoison, many precautions are supposed to be necessary.

The women and young girls are not allowed to be present, lest the Yabahou, or evil spirit, should do them harm. 'The shed under which it has been boiled is pronounced polluted, and abandoned ever after. He who makes the poison must eat nothing that morning, and must continue fasting as long as the operation lasts. The pot in which it is boiled must be a new one, and must never have held anything before, otherwise the poison would be deficient in strength: add to this, that the operator must take particular care not to expose himself to the vapour which arises from it while on the fire.

Though this and other precautions are taken, such as frequently washing the face and hands, still the Indians think that it affects the health; and the operator either is, or, what is more probable, supposes himself to be, sick for some days after.

Thus it appears that the making the wouralipoison is considered as a gloomy and mysterious operation; and it would seem that they imagine 
it affects others as well as him who boils it; for an Indian agreed one evening to make some for me, but the next morning he declined having anything to do with it, alleging that his wife was with child!

Here it might be asked, are all the ingredients just mentioned necessary, in order to produce the wourali-poison? Though our opinions and conjectures may militate against the absolute necessity of some of them, still it would be hardly fair to pronounce them added by the hand of superstition, till proof positive can be obtained.

We might argue on the subject, and, by bringing forward instances of Indian superstition, draw our conclusion by inference, and still remain in doubt on this head. You know superstition to be the offspring of ignorance, and of course that it takes up its abode amongst the rudest tribes of uncivilized man. It even too often resides with man in his more enlightened state.

The Augustan age furnishes numerous examples. A bone snatched from the jaws of a fasting bitch, and a feather from the wing of a night owl, _-"ossa ab ore rapta jejunæ canis, plumamque nocturnæ strigis," -were necessary for Canidia's incantations. And in aftertimes, parson Evans, the Welshman, was treated most ungenteelly by an enraged spirit, solely because he had forgotten a fumigation in his witch-work.

If, then, enlightened man lets his better sense give way, and believes, or allows himself to be persuaded, that certain substances and actions, in reality of no avail, possess a virtue which renders them useful in producing the wished-for 
effects; may not the wild, untaught, unenlightened savage of Guiana add an ingredient which, on account of the harm it does him, he fancies may be useful to the perfection of his poison, though in fact it be of no use at all? If a bone snatched from the jaws of a fasting bitch be thought necessary in incantation; or if witcheraft have recourse to the raiment of the owl, because it resorts to the tombs and mausoleums of the dead, and wails and hovers about at the time that the rest of animated nature sleeps; certainly the savage may imagine that the ants, whose sting causes a fever, and the teetl of the Labarri and Couanacouchi snakes, which convey death in a very short space of time, are essentially necessary in the composition of his poison; and being once impressed with this idea, he will add them every time he makes the poison, and transmit the absolute use of them to his posterity. The question to be answered seems not to be, if it is natural for the Indians to mix these ingredients, but, if they are essential to make the poison.

So much for the preparing of this vegetable essence; terrible importer of death, into whatever animal it enters. Let us now see how it is used; let us examine the weapons which bear it to its destination, and take a view of the poor victim, from the time he receives his wound till death comes to his relief.

When a native of Macoushia goes in quest of feathered game or other birds, he seldom carries his bow and arrows. It is the blow-pipe he then uses. This extraordinary tube of death is, perhaps one of the greatest natural curiosities of Guiana. 
It is not found in the country of the Macoushi. Those Indians tell you that it grows to the southwest of them, in the wilds which extend betwixt them and the Rio Negro. The reed must grow to an amazing lengtl, as the part the Indians use is from ten to eleven feet long, and no tapering can be perceived in it, one end being as thick as the other. It is of a bright yellow colour, perfectly smooth both inside and out. It grows hollow; nor is there the least appearance of a knot or joint throughout the whole extent. The natives call it Ourah. This, of itself, is too slender to answer the end of a blow-pipe; but there is a species of palma, larger and stronger, and common in Guiana, and this the Indians make use of as a case, in which they put the ourah. It is brown, susceptible of a fine polish, and appears as if it had joints five or six inches from each other. It is called Samourah, and the pulp inside is easily extracted, by steeping it for a few days in water.

Thus the ourah and samourah, one within the other, form the blow-pipe of Guiana. The end which is applied to the mouth is tied round with a small silk-grass cord, to prevent its splitting; and the other end, which is apt to strike against the ground, is secured by the seed of the Acnero fruit, cut horizontally through the middle, with a hole made in the end, through which is put the extremity of the blow-pipe. It is fastened on with string on the outside, and the inside is filled up with wild hees'-wax.

The arrow is from nine to ten inches long. It is made out of the leaf of a species of palm-tree, 


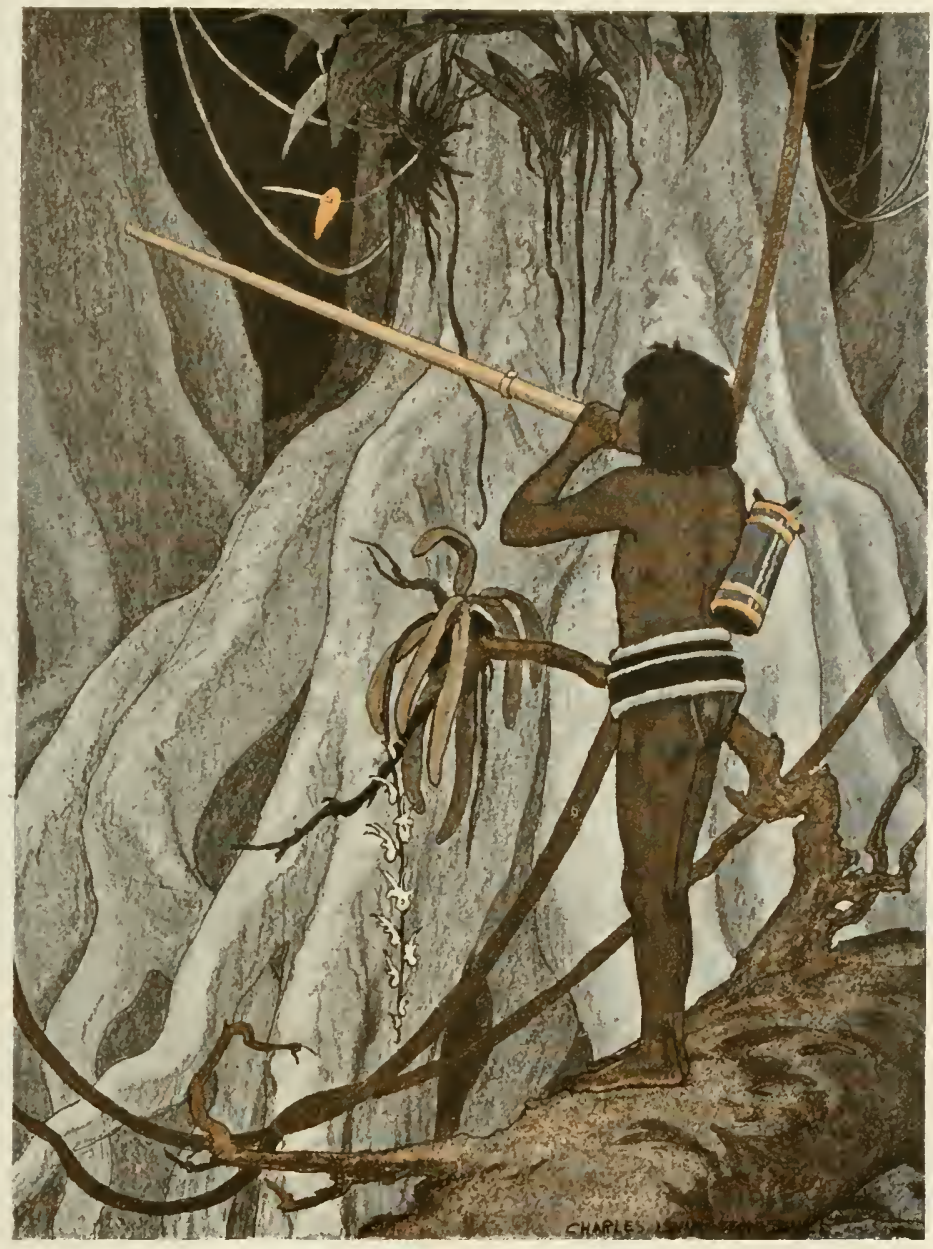

Macoushia Indian with Blow-pipe 

called Concourite, hard and brittle, and pointed as sharp as a needle. About an inch of the pointed end is poisoned. The other end is burnt to make it still harder, and wild cotton is put round it for about an inch and a half. It requires considerable practice to put on this cotton well. It must just be large enongh to fit the hollow of the tube, and taper off to nothing downwards. They tie it on with a thread of the sillk-grass, to prevent its slipping off the arrow.

The Indians have shown ingenuity in making a quiver to hold the arrows. It will contain from five to six hundred. It is generally from twelve to fourteen inches long, and in shape resembles a dice-box used at backgammon. The inside is prettily done in basket-work, with wood not unlike bamboo, and the outside has a coat of wax. The cover is all of one piece, formed out of the skin of the tapir. Round the centre there is fastened a loop, large enough to admit the arm and shoulder from which it liangs when used. To the rim is tied a little bunch of silk-grass, and half of the jaw-bone of the fish called pirai, with which the Indian scrapes the point of his arrow.

Before he puts the arrows into the quiver, he links them together by two strings of cotton, one string at each end, and then folds them round a stick, which is nearly the length of the quiver. The end of the stick, which is uppermost, is guarded by two little pieces of wood crosswise, with a hoop round their extremities, which appears something like a wheel; and this saves the hand from being wounded when the quiver is 
reversed in order to let the bunch of arrows drop out.

There is also attached to the quiver a little kind of basket, to hold the wild cotton which is put on the blunt end of the arrow. With a quiver of poisoned arrows slung over his shoulder, and with his blow-pipe in his hand, in the same position as a soldier carries his musket, see the Macoushi Indian advancing towards the forest in quest of powises, maroudis, waracabas, and other feathered game.

These generally sit high up in the tall and tufted trees, but still are not out of the Indian's reach; for his blow-pipe, at its greatest elevation, will send an arrow three hundred feet. Silent as midnight he steals under them, and so cautiously does he tread the ground, that the fallen leaves rustle not beneath his feet. His ears are open to the least sound, while his eye, keen as that of the lynx, is employed in finding out the game in the thickest shade. Often he imitates their cry, and decoys them from tree to tree, till they are within range of his tube. Then taking a poisoned arrow from his quiver, he puts it in the blow-pipe, and collects his breath for the fatal puff.

About two feet from the end through which he blows there are fastened two teeth of the acouri, and these serve him for a sight. Silent and swift the arrow flies, and seldom fails to pierce the object at which it is sent. Sometimes the wounded bird remains in the same tree where it was shot, and in three minutes falls down at the Indian's feet. Should he take wing, his flight is of short 
duration, and the Indian, following the direction he has gone, is sure to find him dead.

It is natural to imagine that, when a slight wound only is inflicted, the game will make its escape. Far otherwise; the romrali-poison almost instantaneously mixes with blood or water, so that if you wet your finger, and dash it along the poisoned arrow in the quickest manner possible, you are sure to carry off some of the poison. Though three minutes generally elapse before the convulsions come on in the wounded bird, still a stmpor evidently takes place sooner, and this stupor manifests itself by an apparent unwillingness in the bird to move. This was very visible in a dring forvl.

Having procured a healthy full-gromn one, a short piece of a poisoned blow-pipe arrow was broken off and run up into its thigh, as near as possible betwixt the skin and the flesh, in order that it might not be incommoded by the wound. For the first minute it walked about, but walked very slowly, and did not appear the least agitated. During the second minute it stood still, and began to peck the ground; and ere half another had elapsed, it frequently opened and shut its mouth. The tail had now dropped, and the wings almost touched the ground. Br the termination of the third minute, it lad sat down, scarce able to support its head, which nodded, and then recovered itself, and then nodded again, lower and lower every time. like that of a weary traveller slumbering in an erect position; the eyes alternately open and shut. The fourth minute brought on convulsions, and life and the fifth terminated together. 
The flesh of the game is not in the least injured by the poison, nor does it appear to corrupt sooner than that killed by the gun or knife. The body of this fowl was kept for sixteen hours, in a climate damp and rainy, and within seven degrees of the equator; at the end of which time it had contracted no bad smell whatever, and there were no symptoms of putrefaction, saving that, just round the wound, the flesh appeared somewhat discoloured.

The Indian, on his return home, carefully suspends his blow-pipe from the top of his spiral roof; seldom placing it in an oblique position, lest it should receive a cast.

Here let the blow-pipe remain suspended, while you take a view of the arms which are made to slay the larger beasts of the forest.

When the Indian intends to chase the peccari, or surprise the deer, or rouse the tapir from his marshy retreat, he carries his bow and arrows, which are very different from the weapons already described.

The bow is generally from six to seven feet long, and strung with a cord, spun out of the silkgrass. The forests of Guiana furnish many species of hard wood, tough and elastic, out of which beautiful and excellent bows are formed.

The arrows are from four to five feet in length, made of a yellow reed without a knot or joint. It is found in great plenty up and down throughout Guiana. A piece of hard wood, about nine inches long, is inserted into the end of the reed, and fastened with cotton well waxed. A square hole, an inch deep, is then made in the end of this piece of 
hard wood, done tight round with cotton to keep it from splitting. Into this square hole is fitted a spike of Concourite wood, poisoned, and which may be kept there, or taken out at pleasure. A joint of bamboo, about as thick as your finger, is fitted on over the poisoned spike, to prevent accidents and defend it from the rain, and is taken off when the arrow is about to be used. Lastly, two feathers are fastened on the other end of the reed to steady it in its flight.

Besides his bow and arrows, the Indian carries a little box made of bamboo, which holds a dozen or fifteen poisoned spikes, six inches long. They are poisoned in the following manner: a small piece of wood is dipped in the poison, and with this they give the spike a first coat. It is then exposed to the sun or fire. After it is dry, it receives another coat, and is then dried again; after this a third coat, and sometimes a fourth.

They take great care to put the poison on thicker at the middle than at the sides, by which means the spike retains the shape of a two-edged sword. It is rather a tedious operation to make one of these arrows complete; and as the Indian is not famed for industry, except when pressed by hunger, he has hit upon a plan of preserving his arrows which deserves notice.

About a quarter of an inch above the part where the Coucourite spike is fixed into the square hole, he cuts it half through; and thus, when it has entered the animal, the weight of the arrow causes it to break off there, by which means the arrow falls to the ground uninjured; so that, should this be the only arrow he happens to have 
with him, and should another shot immediately occur, he has only to take another poisoned spike out of his little bamboo box, fit it on his arrow, and send it to its destination.

Thus armed with deadly poison, and hungry as the hyæna, he ranges throngh the forest in quest of the wild beasts' track. No hound can act a surer part. Withont clothes to fetter him, or shoes to bind his feet, he observes the footsteps of the game, where an Enropean eye conld not discern the smallest vestige. He pursues it through all its turns and windings, with astonishing perseverance, and success generally crowns his efforts. The animal, after receiving the poisoned arrow, seldom retreats two hundred paces before it drops.

In passing overland from the Essequibo to the Demerara we fell in with a herd of wild hogs. Though encumbered with baggage, and fatigued with a hard day's walk, an Indian got his bow ready, and let fly a poisoned arrow at one of them. It entered the cheek-bone and broke off. The wild hog was found quite dead about one hundred and seventy paces from the place where he had been shot. He afforded us an excellent and wholesome supper.

Thus the savage of Guiana, independent of the common weapons of destruction, has it in his power to prepare a poison, by which he can generally ensure to himself a supply of animal food; and the food so destroyed imbibes no deleterions qualities. Nature has been bountiful to him. She has not only ordered poisonous herbs and roots to grow in the unbounded forests through 
which he strays, but has also furnished an excellent reed for his arrows, and another, still more singular, for his blow-pipe; and planted trees of an amazing hard, tough, and elastic texture, out of which he forms his bows. And in order that nothing might be wanting, she has superadded a tree which yields him a fine $\pi a x$, and desseminated up and down a plant not unlike that of the pine-apple, which affords him capital bow-strings. 


\section{CHAPTER III}

Having now followed the Indian in the chase, and described the poison, let us take a nearer view of its action, and observe a large animal expiring under the weight of its baneful virulence.

Many have doubted the strength of the wouralipoison. Should they ever by chance read what follows, probably their doubts on that score will be settled for ever.

In the former experiment on the hog, some faint resistance on the part of nature was observed, as if existence struggled for superiority; but in the following instance of the sloth, life sank in death without the least apparent contention, without a cry, without a struggle, and without a groan. This was an $\mathrm{Ai}$, or three-toed Sloth. It was in the possession of a gentleman who was collecting curiosities. He wished to have it killed, in order to preserve the skin, and the wourali-poison was resorted to as the easiest deatli.

Of all animals, not even the toad and tortoise excepted, this poor ill-formed creature is the most tenacious of life. It exists long after it has received wounds which would have destroyed any other animal; and it may be said, on seeing a mortally-wounded sloth, that life disputes with death every inch of flesh in its body.

The Ai was wounded in the leg, and put down on the floor, about two feet from the table; it con- 
trived to reach the leg of the table and fastened himself on it, as if wishful to ascend. But this was its last advancing step: life was ebbing fast, though imperceptibly; nor could this singular production of nature, which has been formed of a texture to resist death in a thousand shapes, make any stand against the wourali-poison.

First, one fore-leg let go its hold, and dropped down motionless by its side; the other gradually did the same. The fore-legs having now lost their strength, the sloth slowly doubled its body, and placed its head betwixt its hind-legs, which still adhered to the table; but when the poison had affected these also, it sank to the ground, but sank so gently, that you could not distinguish the movement from an ordinary motion; and had you been ignorant that it was wounded with a poisoned arrow, you would never have suspected that it was dying. Its mouth was shut, nor had any froth or saliva collected there.

There was no subsultus tendinum, or any visible alteration in its breathing. During the tenth minute from the time it was wounded it stirred, and that was all; and the minute after, life's last spark went out. From the time the poison began to operate, you would have conjectured that sleep was overpowering it, and you would have exclaimed, "Pressitque jacentem, dulcis et alta quies, pacidæque simillima morti."

There are now two positive proofs of the effect of this fatal poison; viz., the death of the hog, and that of the sloth. But still these animals were nothing remarkable for size; and the strength of 
the poison in large animals might yet be doubted, were it not for what follows.

A large well-fed ox, from nine hundred to a thousand pounds weight, was tied to a stake by a rope sufficiently long to allow him to move to and fro. Having no large Coucourite spikes at haud, it was judged necessary, on account of his superior size, to put three wild-hog arrows into him; one was sent into each thigh just above the hock, in order to avoid wounding a vital part, and the third was shot transversely into the extremity of the nostril.

The poison seemed to take effect in four minutes. Conscious as though he would fall, the ox set himself firmly on his legs, and remained quite still in the same place, till about the fourteenth minute, when he smelled the ground, and appeared as if inclined to walk. He advanced a pace or two, staggered, and fell, and remained extended on his side with his head on the ground. His eye, a few minutes ago so bright and lively, now became fixed and dim, and though you put your hand close to it as if to give him a blow there, he never closed his eyelid.

His legs were convulsed, and his head from time to time started involuntarily; but he never showed the least desire to raise it from the ground; he breathed hard, and emitted foam from his moutl. 'The startings, or' subsultus tendinum, now became gradually weaker and weaker; his hinder parts were fixed in death; and in a minute or two more his head and fore-leg's ceased to stir.

Nothing now remained to show that life was still within him, except that his heart faintly beat 
and fluttered at intervals. In five-and-twenty minutes from the time of his being wounded he was quite dead. His flesh was very sweet and savoury at diuner.

On taking a retrospective view of the two different kinds of poisoned arrows, and the animals destroyed by them, it would appear that the quantity of poison must be proportioned to the animal, and thus those probably labour under an error who imagine that the smallest particle of it introduced into the blood has almost instantaneous effect.

Nake an estimate of the difference in size betwixt the forl and the ox, and then weigh a sufficient quantity of poison for a blow-pipe arrow with which the fowl was killed, and weigh also enough poison for three wild-hog arrows which destroyed the ox, and it will appear that the fowl received much more poison in proportion than the ox. Hence the cause why the fowl died in five minutes, and the ox in fire-and-twenty.

Indeed, were it the case that the smallest particle of it introduced into the blood has almost instantaneous effects, the Indian would not find it necessary to make the large arrow; that of the blow-pipe is much easier made and requires less poison.

And now for the antidotes, or rather the supposed antidotes. The Indians tell you, that if the rounded animal be held for a considerable time up to the mouth in water, the poison will not prove fatal; also that the juice of the sugar-cane poured down the throat will counteract the effects of it. These antidotes were fairly tried upon 
full-grown healthy fowls, but they all died, as though no steps had been taken to preserve their lives. Rum was recommended and given to another, but with as little success.

It is supposed by some, that wind introduced into the lungs by means of a small pair of bellows would revive the poisoned patient, provided the operation be continued for a sufficient length of time. It may be so; but this is a difficult and a tedious mode of cure, and he who is wounded in the forest far away from his friends, or in the hut of the savages, stands but a poor chance of being saved by it.

Had the Indians a sure antidote, it is likely they would carry it about with them, or resort to it immediately after being wounded, if at hand; and their confidence in its efficacy would greatly diminish the horror they betray, when you point a poisoned arrow at them.

One day, while we were eating a red monkey, erroneously called the baboon in Demerara, an Arowack Indian told an affecting story of what happened to a comrade of his. He was present at his death. As it did not interest this Indian in any point to tell a falsehood, it is very probable that his account was a true one. If so, it appears that there is no certain antidote, or at least no antidote that could be resorted to in a case of urgent need; for the Indian gave up all thoughts of life as soon as he was wounded.

The Arowack Indian said it was but four years ago that he and his companion were ranging in the forest in quest of game. His companion took a poisoned arrow, and sent it at a red monkey in 
a tree above him. It was nearly a perpendicular shot. The arrow missed the monkey, and in the descent, struck him in the arm, a little above the elbow. He was convinced that it was all over with him. "I shall never," said he to his companion in a faltering' voice, and looking at his bow as he said it, "I shall never," said he, "bend this bow again." And having said that, he took off his little bamboo poison-box, which hung across his shoulder, and putting it together with his bow and arrows on the ground, he laid himself down close by them, bid his companion farewell, and never spoke more.

He who is unfortunate enough to be wounded by a poisoned arrow from Macoushia had better not depend upon the common antidotes for a cure. Many who have been in Guiana will recommend immediate immersion in water, or to take the juice of the sugar-eane, or to fill the mouth full of salt; and they recommend these antidotes because they have got them from the Indians. But were you to ask them if they ever saw these antidotes used with success, it is ten to one their answer would be in the negative.

Wherefore let him reject these antidotes as unprofitable, and of no avail. He has got an active and deadly foe within him, which, like Shakespeare's fell Sergeant Death, is strict in his arrest, and will allow him but little time-very-very little time. In a few minutes he will be numbered with the dead. Life ought, if possible, to be preserved, be the expense ever so great. Should the part affected admit of it, let a ligature be tied 


\section{WANDERINGS IN SOUTH AMERICA}

tight round the wound, and have immediate recourse to the knife:-

"Continuo, culpam ferro compesce priusquam,

Dira per infaustum serpant contagia corpus."

And now, kind reader, it is time to bid thee farewell. The two ends proposed have been obtained. The Portuguese inland frontier fort has been reached, and the Macoushi womrali-poison acquired. The account of this excursion through the interior of Guiana has been submitted to thy perusal, in order to induce thy abler genius to undertake a more extensive one. If any difficulties have arisen, or fevers come on, they have been caused by the periodical rains, which fall in torrents as the sun approaches the tropic of Cancer. In dry weather there would be no difficulties or sickness.

Amongst the many satisfactory conclusions which thou wouldst be able to draw during the journey, there is one which, perhaps, would please thee not a little; and that is with regard to dogs. Many a time, no doubt, thou hast heard it hotly disputed, that dogs existed in Guiana previously to the arrival of the Spaniards in those parts. Whatever the Spaniards introduced, and which bore no resemblance to anything the Indians had been accustomed to see, retains its Spanish name to this day.

Thus the Warow, the Arowac, the Acoway, the Maconshi, and Carib tribes, call a hat, sombrero; a shirt, or any kind of cloth, camiso; a shoe, zapato; a letter, carta; a fowl, gallina; gunpowder, 
colvora, (Spanish, polvora); ammunition, bala ; a cow, baca; and a dog, perro.

This argues strongly against the existence of dogs in Guiana before it was discovered by the Spaniards, and probably may be of use to thee, in thy next canine dispute.

In a political point of view this country presents a large field for speculation. A few years ago there was but little inducement for any Englishman to explore the interior of these rich and fine colonies, as the British Government did not consider them worth holding at the peace of Amiens. Since that period their mother-country has been blotted out from the list of nations, and America has unfolded a new sheet of politics. On one side, the crown of Braganza, attacked by an ambitious chieftain, has fled from the palace of its ancestors, and now seems fixed on the banks of the Janeiro. Cayenne has yielded to its arms. La Plata has raised the standard of independence, and thinks itself sufficiently strong to obtain a government of its own. On the other side, the Caraccas are in open revolt, and should Santa Fe join them in good earnest, they may form a powerful association.

Thus, on each side of the ci-devant Dutch Guiana, most unexpected and astonishing changes have taken place. Will they raise or lower it in the scale of estimation at the Court of St. James? Will they be of benefit to these grand and extensive colonies? Colonies enjoying perpetual summer. Colonies of the richest soil. Colonies containing within themselves everything necessary for their support. Colonies, in fine, so varied 


\section{WANDERINGS IN SOUTH AMERICA}

in their quality and situation, as to be capable of bringing to perfection every tropical production; and only want the support of government, and an enlightened governor, to render them as fine as the finest portions of the equatorial regions. Kind reader, fare thee well.

\section{LETTER TO THE PORTUGUESE COMMANDER}

\section{MUY SEÑor,}

Como no tengo el honor, de ser conocido de VM. lo pienso mejor, y mas decoroso, quedarme aqui, hastaque huviere recibido su respuesta. Haviendo caminado hasta la chozo, adonde estoi, no quisiere volverme, antes de haver visto la fortaleza de los Portugueses; y pido licencia de VM. para que me adelante. Honradissimos son mis mativos, ni tengo proyecto ninguno, o de comercio, o de la soldadesca, no siendo yo, o comerciante, o oficial. Hidalgo catolico soy, de hacienda in Ynglatierra, y muchos años de mi vida he pasado en caminar. Ultimamente, de Demeraria vengo, la qual dexé el 5 dia de Abril, para ver este hermoso pais, y coger unas curiosidades, especialmente, el reneno, que se llama wourali. Las mas recentes noticias que tenian en Demeraria, antes de mi salida, eran medias tristes, medias alegres. Tristes digo, viendo que Valencia ha caido en poder del enemigo comun, y le General Blake, y sus valientes tropas quedan prisioneros de guerra. Alegres, al contrario, porque Milord Wellington se ha apoderado de Ciudad Rodrigo. A pesar de la caida de Valencia, parece claro al mundo, que las cosas del enemigo, estan andando, de pejor a pejor eada dia. Nosotros debemos dar gracias al Altissimo, por haver sido servido dexaruos castigar ultimamente, a los robadores de sus santas Yglesias. Se vera VM. que yo no escribo Portugues ni aun lo hablo, pero, haviendo aprendido el Castellano, no nos faltara medio de communicar y tener conversacion. Ruego se escuse esta carta escrita sin tinta, porque un Indio dexo caer mi tintero y quebrose. Dios le dé a VM. muchos años de salud. Entretanto, tengo el honor de ser

Su mas obedeciente servidor, 


\section{REMARKS}

"Incertus, quo fata ferant, ubi sistere detur."

Kind and gentle reader, if the journey in quest of the wourali-poison has engaged thy attention, probably thou mayest recollect that the traveller took leave of thee at Fort St. Joachim, on the Rio Branco. Shouldest thou wish to know what befell him afterwards, excuse the following uninteresting narrative.

Having had a return of fever, and aware that the farther he advanced into these wild and lonely regions, the less would be the chance of regaining his health; he gave up all idea of proceeding onwards, and went slowly back towards the Demerara, nearly by the same route he had come.

On descending the falls in the Essequibo, which form an oblique line quite across the river, it was resolved to push through them, the downward stream being in the canoe's favour. At a little distance from the place, a large tree had fallen into the river, and in the meantime the canoe was lashed to one of its branches.

The roaring of the water was dreadful; it foamed and dashed over the rocks with a tremendous spray, like breakers on a lee-shore, threatening destruction to whatever approached it. You would have thought, by the confusion it 
caused in the river, and the whirlpools it made, that Scylla and Charybdis, and their whole progeny, had left the Mediterranean, and come and settled here. The channel was barely twelve feet wide, and the torrent in rushing down formed traverse furrows, which showed how near the rocks were to the surface.

Nothing could surpass the skill of the Indian who steered the canoe. He looked steadfastly at it, then at the rocks, then cast an eye on the channel, and then looked at the canoe again. It was in vain to speak. The sound was lost in the roar of waters; but his eye showed that he had already passed it in imagination. He held up his paddle in a position, as much as to say, that he would keep exactly amid channel; and then made a sign to cut the bush rope that held the canoe to the fallen tree. The canoe drove down the torrent with inconceivable rapidity. It did not touch the rocks once all the way. The Indian proved to a nicety, "medio tutissimus ibis."

Shortly after this it rained almost day and night, the lightning flashing incessantly, and the roar of thunder awful beyond expression.

The fever returned, and pressed so heavy on him, that to all appearance his last day's march was over. However, it abated; his spirits rallied, and he marched again; and after delays and inconveniences he reached the house of his worthy friend, Mr. Edmonstone, in Mibiri Creek, which falls into the Demerara. No words of his can do justice to the hospitality of that gentleman, whose repeated encounters with the hostile negroes in the forest have been publicly rewarded, 
and will be remembered in the colony for years to come.

Here he learned that an eruntion had talen place in St. Vincent's; and thus hoise heard in the night of the first of liay, which had cantsod? such terror amongst the Iridians, and made tie garrison at Fort St. Joachim remain under arms the rest of the night, is accounted for.

After experiencing every kindness and attention from Mr. Edmonstone, he sailed for Granada, and from thence to St. Thomas's, a few days before poor Captain Peake lost his life on his own quarter-deck, bravely fighting for his country on the coast of Guiana.

At St. Thomas's they show you a tower, a little distance from the town, which they say formerly belonged to a Bucanier chieftain. Probably the fury of besiegers has reduced it to its present dismantled state. What still remains of it bears testimony of its former strength, and may brave the attack of time for centuries. You cannot view its ruins without calling to mind the exploits of. those fierce and hardy hunters, long the terror of the western world. While you admire their. undaunted courage, you lament that it was often stained with cruelty; while you extol their scrupulous justice to each other, you will find a want of it towards the rest of mankind. Often possessed of enormous wealth, often in extreme poverty, often triumphant on the ocean, and often forced to fly to the forests, their life was an everchanging scene of advance and retreat, of glory and disorder, of luxury and famine. Spain treated them as outlaws and pirates, while other 


\section{WANDERINGS IN SOU'TH AMERICA}

European powers publicly disowned them. They, on the other hand, maintained that injustice on the part of Spain first forced them to take up arins in seif défence; and that, whilst they kept inviolable the laws "which they had framed for their own common benefit and protection, they had a right to consider as foes those who treated them as outlaws. Under this impression they drew the sword, and rushed on as though in lawful war, and divided the spoils of victory in the scale of justice.

After leaving St. Thomas's a severe tertian ague every now and then kept putting the traveller in mind that his shattered frame, "starting and shivering in the inconstant blast, meagre and pale-the ghost of what it was"-wanted repairs. Three years elapsed after arriving in England before the ague took its final leave of him.

During that time several experiments were made with the wourali-poison. In London an ass was inoculated with it, and died in twelve minutes. The poison was inserted into the leg of another, round which a bandage had been previously tied a little above the place where the wourali was introdnced. He walked about as usual, and ate his food as though all were right. After an hour had elapsed the bandage was untied, and ten minutes after death overtook him.

A she-ass received the wourali-poison in the shoulder, and died apparently in ten minutes. An incision was then made in its windpipe, and through it the lungs were regularly inflated for two hours with a pair of bellows. Suspended 


\section{WANDERINGS IN SOUTH AMERICA 103}

animation returned. The ass held up her head, and looked around; but the inflating being discontinued, she sunk once more in apparent deatl. The artificial breathing was immediately recommenced, and continued without intermission for two hours. This saved the ass from final dissolution; she rose up, and walked about; she seemed neither in agitation nor in pain. The wound, through which the poison entered, was healed without difficulty. Her constitution, however, was so severely affected that it was long a doubt if ever she would be well again. She looked lean and sickly for above a year, but began to mend the spring after, and by Midsummer became fat and frisky.

The kind-hearted reader will rejoice on learning that Earl Percy, pitying her misfortunes, sent her down from London to Walton Hall, near Wakefield. There she goes by the name of Wouralia. Wouralia shall be sheltered from the wintry storm; and when summer comes she shall feed in the finest pasture. No burden shall be placed upon her, and she shall end her days in peace. ${ }^{1}$

For three revolving autumns the ague-beaten wanderer never saw, without a sigh, the swallow bend her flight towards warmer regions. He wished to go, too, but could not; for sickness had enfeebled him, and prudence pointed out the folly of roving again too soon across the northern tropic. To be sure, the continent was now open, and change of air might prove beneficial; but

1 Poor Wouralia breathed her last on the 15th of February, 1839. having survived the operation nearly five-and-twenty years. 


\section{WANDERINGS IN SOUTH AMERICA}

there was nothing very tempting in a trip across the Channel, and as for a tour through England! -England has long ceased to be the land for adventures. Indeed, when good King Arthur reappears to claim his crown he will find things strangely altered here; and may we not look for his coming? for there is written upon his gravestone:-

"Hic jacet Arturus, Rex quondam Rexque futurus,"

"Here Arthur lies, who formerly

Was king-and king again to be."

Don Quixote was always of opinion that this famous king did not die, but that he was changed into a raven by enchantment, and that the English are momentarily expecting his return. Be this as it may, it is certain that when he reigned here all was harmony and joy. The browsing herds passed from vale to vale, the swains sang from the bluebell-teeming groves, and nymphs with eglantine and roses in their neatly-braided hair went hand in hand to the flowery mead to weave garlands for their lambkins. If by chance some rude, uncivil fellow dared to molest them, or attempted to throw thorns in their path, there was sure to be a knight-errant not far off ready to rush forward in their defence. But alas! in these degenerate days it is not so. Should a harmless cottage maid wander out of the highway to pluck a primrose or two in the neighbouring field the haughty owner sternly bids her retire; and if a pitying swain hasten to escort her back, he is perhaps seized by the gaunt housedog ere he reach her. 
Eneas's route on the other side of Styx could not have been much worse than this, though, by his account, when he got back to earth, it appears that he had fallen in with "Bellua Lernæ, horrendum stridens, flammisque, armata Chimæra."

Moreover, lie had a sibyl to guide his steps; and as such a conductress nowadays could not be got for love nor money, it was judged most prudent to refrain from sauntering through this land of freedom, and wait with patience the return of health. At last this long-looked for, ever welcome stranger came. 


\section{SECOND JOURNEY}

\section{CHAPTER I}

In the year 1816, two days before the vernal equinox, I sailed from Liverpool for Pernambuco, in the southern hemisphere, on the coast of Brazil. There is little at this time of the year in the European part of the Atlantic to engage the attention of the naturalist. As you go down the Channel you see a few divers and gannets. The middle-sized gulls, with a black spot at the end of the wings, attend you a little way into the Bay of Biscay. When it blows a hard gale of wind the stormy petrel makes its appearance. While the sea runs mountains high, and every wave threatens destruction to the labouring vessel this little harbinger of storms is seen enjoying itself, on rapid pinion, up and down the roaring billows. When the storm is over it appears no more. It is known to every English sailor by the name of Mother Carey's Chicken. It must have been hatched in Eolus's cave, amongst a clutch of squalls and tempests; for whenever they get out upon the ocean it always contrives to be of the party.

Though the calms and storms, and adverse winds in these latitudes are vexatious, still, when you reach the trade winds you are amply repaid for all disappointments and inconveniences. The 
trade winds prevail about thirty degrees on each side of the equator. This part of the ocean may be called the Elysian Fields of Neptune's Empire; and the torrid zone, notwithstanding Ovid's remark, "non est habitabilis restu," is rendered healthy and pleasant by these gently-blowing breezes. The ship glides smoothly on, and you soon find yourself within the northern tropic. When you are on it, Cancer is just over your head, and betwixt him and Capricorn is the high road of the Zodiac forty-seven degrees wide, famous for Plaeton's misadventure. His father begged and entreated him not to take it into his head to drive parallel to the five zones, but to mind and keep on the turnpike which runs obliquely across the equator. "There you will distinctly see," said he, "the ruts of my chariot wheels, 'manifesta rotæ vestigia cernes.' But," added he, "even suppose you keep on it, and avoid the by-roads, nevertheless, my dear boy, believe me, you will be most sadly put to your shifts ; 'ardua prima via est,' the first part of the road is confoundedly steep! 'ultima via prona est,' and after that it is all down hill. Moreover, 'per insidias iter est, formasque ferarum,' the road is full of nooses and bull-dogs, 'Hæmoniosque arcus,' and spring guns, 'sævaque circuitu, curvantem brachia longo, Scorpio,' and steel traps of uncommon size and shape." These were nothing in the eyes of Phaeton; go he would, so off he set, full speed, four-in-hand. He had a tough drive of it; and after doing a prodigious deal of mischief, very luckily for the world, he 


\section{WANDERINGS IN SOUTH AMERICA}

got thrown out of the box, and tumbled into the river Po.

Some of our modern bloods have been shallow enough to try to ape this poor, empty-headed coachman, on a little scale, making London their Zodiac. Well for them, if tradesmen's bills, and other trivial perplexities, have not caused them to be thrown into the King's Bench.

The productions of the torrid zone are uncommonly grand. Its plains, its swamps, its savannas, and forests abound with the largest serpents and wild beasts; and its trees are the habitation of the most beautiful of the feathered race. While the traveller in the old world is astonished at the elephant, the tiger, the lion, and rhinoceros, he who wanders through the torrid regions of the new, is lost in admiration at the cotingas, the toucans, the humming-birds, and aras.

The ocean, likewise, swarms with curiosities. Probably the Flying-fish may be considered as one of the most singular. This little scaled inhabitant of water and air seems to have been more favoured than the rest of its finny brethren. It can rise out of the waves, and on wing visit the domain of the birds.

After flying two or three hundred yards, the intense heat of the sun has dried its pellucid wings, and it is obliged to wet them in order to continue its flight. It just drops into the ocean for a moment, and then rises again and flies on; and then descends to remoisten them, and then up again into the air ; thus passing its life, sometimes wet, sometimes dry, sometimes in sunshine, and sometimes in the pale moon's nightly beam, 
as pleasure dictates, or as need requires. The additional assistance of wings is not thrown away upon it. It has full occupation both for fins and wings, as its life is in perpetual danger.

The Bonito and Albicore chase it day and night; but the Dolphin is its worst and swiftest foe. If it escape into the air, the dolphin pushes on with proportional velocity beneath, and is ready to snap it up the moment it descends to wet its wings.

You will often see above one hundred of these little marine aerial fugitives on the wing at once. They appear to use every exertion to prolong their flight, but vain are all their efforts; for when the last drop of water on their wings is dried up, their flight is at an end, and they must drop into the ocean. Some are instantly devoured by their merciless pursuer, part escape by swimming, and others get out again as quick as possible, and trust once more to their wings.

It often happens that this unfortunate little creature, after alternate dips and flights, finding all its exertions of no avail, at last drops on board the vessel, verifying the old remark,

"Ineidit in Seyllam, cupiens vitare Charybdim."

There, stunned by the fall, it beats the deck with its tail and dies. When eating it, you would take it for a fresh herring. The largest measure from fourteen to fifteen inches in length. The dolphin, after pursuing it to the ship, sometimes forfeits his own life.

In days of yore, the musician used to play in softest, sweetest strain, and then take an airing 


\section{WANDERINGS IN SOUTH AMERICA}

amongst the dolphins; "inter delphinas Arion." But nowadays, our tars have quite capsized the custom; and instead of riding ashore on the dolphin, they invite the dolphin aboard. While he is darting and playing around the vessel, a sailor goes out to the spritsailyard-arm, and with a long staff, leaded at one end, and armed at the other with five barbed spikes, he heaves it at him. If successful in his aim, there is a fresh mess for all hands. The dying dolphin affords a superb and brilliant sight:

"Mille trahit moriens, adverso sole colores."

All the colours of the rainbow pass and repass in rapid succession over his body, till the dark hand of death closes the scene.

From the Cape de Verd islands to the coast of Brazil, you see several different kinds of gulls, which probably are bred in the island of St. Paul. Sometimes the large bird called the Frigate Pelican soars majestically over the vessel, and the Tropic-Bird comes near enough to let you have a fair view of the long feathers in his tail. On the line, when it is calm, Sharks of a tremendous size make their appearance. They are descried from the ship by means of the dorsal fin, which is above the water.

On entering the bay of Pernambuco, the Frigate Pelican is seen watching the shoals of fish from a prodigious height. It seldom descends without a successful attack on its numerous prey below.

As you approach the shore, the view is charming. The hills are clothed with wood, gradually 
rising towards the interior, none of them of any considerable height. A singular reef of rocks runs parallel to the coast, and forms the harbour of Pernambuco. The vessels are moored betwixt it and the town, safe from every storm. You enter the harbour through a very narrow passage, close by a fort built on the reef. The hill of Olinda, studded with houses and convents, is on your right hand, and an island thickly planted with cocoa-nut trees, adds considerably to the scene on your left. 'There are two strong forts on the isthmus, betwixt Olinda and Pernambuco, and a pillar midway to aid the pilot.

Pernambuco probably contains upwards of fifty thousand souls. It stands on a flat, and is divided into three parts - a peninsula, an island, and the continent. Though within a few degrees of the line, its climate is remarkably salubrious, and rendered almost temperate by the refreshing sea breeze. Had art and judgment contributed their portion to its natural advantages, Pernambuco at this day, would have been a stately ornament to the coast of Brazil. On viewing it, it will strike you that every one has built his house entirely for himself, and deprived public convenience of the little claim she had a right to put in. You would wish that this city, so famous for its harbour, so happy in its climate, and so well situated for commerce, could have risen under the flag of Dido, in lieu of that of Braganza.

As you walk down the streets, the appearance of the houses is not much in their favour. Some of them are very high, and some very low; some newly whitewashed, and others stained, and 


\section{WANDERINGS IN SOUTH AMERICA}

mouldy, and neglected, as though they had no owner.

The balconies, too, are of a dark and gloomy appearance. They are not, in general, open, as in most tropical cities, but grated like a farmer's dairy window, though somewhat closer.

There is a lamentable want of cleanliness in the streets. The impurities from the houses, and the accumulation of litter from the beasts of burden, are unpleasant sights to the passing stranger. He laments the want of a police as he goes along; and when the wind begins to blow, his nose and eyes are too often exposed to a cloud of very unsavoury dust.

When you view the port of Pernambuco, full of ships of all nations, when you know that the richest commodities of Europe, Africa, and Asia are brought to it; when you see immense quantities of cotton, dye-wood, and the choicest fruits pouring into the town, you are apt to wonder at the little attention these people pay to the common comforts which one always expects to find in a large and opulent city. However, if the inhabitants are satisfied, there is nothing more to be said. Should they ever be convinced that inconveniences exist, and that nuisances are too frequent, the remedy is in their own liands. At present, certainly, they seem perfectly regardless of them; and the Captain-General of Pernambuco walks through the streets with as apparent content and composure as an English statesman would proceed down Charing-cross. Custom reconciles everything. In a week or two the stranger himself begins to feel less the things which annoyed 
him so much upon his first arrival, and after a few months' residence, he thinks no more about them, while he is partaking of the hospitality, and enjoying the elegance and splendour within doors in this great city.

Close by the river-side stands what is called the palace of the Captain-General of Pernambuco. Its form and appearance altogether strike the traveller that it was never intended for the use it is at present put to.

Reader, throw a veil over thy recollection for a little while, and forget the cruel, unjust, and unmerited censures thou hast heard against an unoffending order. This palace was once the Jesuits' college, and originally built by those charitable fathers. Ask the aged and respectable inhabitants of Pernambuco, and they will tell thee that the destruction of the Society of Jesus was a terrible disaster to the public, and its consequences severely felt to the present day.

When Pombal took the reins of power into his own hands, virtue and learning beamed bright within the college walls. Public eatechism to the children, and religious instruction to all, flowed daily from the mouths of its venerable priests.

They were loved, revered, and respected throughout the whole town. The illuminating philosophers of the day had sworn to exterminate Christian knowledge, and the college of Pernambuco was doomed to founder in the general storm. To the long-lasting sorrow and disgrace of Portngal, the philosophers blinded her king and flattered her prime minister. Pombal was exactly the tool these sappers of every public and private 


\section{WANDERINGS IN SOUTH AMERICA}

virtue wanted. He had the naked sword of power in his omn hand, and his heart was as hard as flint. He struck a mortal blow, and the Society of Jesus, throughout the Portuguese dominions, was no more.

One morning all the fathers of the college in Pernambuco, some of them very old and feeble, were suddenly ordered into the refectory. They had notice beforehand of the fatal storm, in pity from the governor, but not one of them abandoned his charge. They had done their duty, and had nothing to fear. They bowed with resignation to the will of Heaven. As soon as they had all reached the refectory, they were there locked up, and never more did they see their rooms, their friends, their scholars, or acquaintance. In the dead of the following night, a strong guard of soldiers literally drove them through the streets to the water's edge. They were then conveyed in boats aboard a ship, and steered for Bahia. Those who survived the barbarous treatment they experienced from Pombal's creatures were at last ordered to Lisbon. The college of Pernambuco was plundered, and some time after an elephant was kept there.

Thus the arbitrary hand of power, in one night, smote and swept away the sciences; to which succeeded the low, vulgar buffoonery of a showman. Virgil and Cicero made way for a wild beast from Angola! and now a guard is on duty at the very gate where, in times long past, the poor were daily fed! ! !

Trust not, kind reader, to the envious remarks which their enemies have scattered far and near; 
believe not the stories of those who have had a hand in the sad tragedy. Go to Brazil, and see with thine own eyes the effect of Pombal's shortsighted policy. There vice reigns triumphant, and learning is at its lowest ebb. Neitler is this to be wondered at. Destroy the compass, and will the vessel find her far-distant port? Will the flock keep together, and escape the wolves, after the shepherds are all slain? The Brazilians were told that public education would go on just as usual. They might have asked government, who so able to instruct our youth as those whose knowledge is proverbial? who so fit, as those who enjoy our entire confidence? who so worthy, as those whose lives are irreproachable?

They soon found that those who succeeded the fathers of the Society of Jesus had neither their manners nor their abilities. They had not made the instruction of youth their particular study. Moreover, they entered on the field after a defeat, where the officers had all been slain; where the plan of the campaign was lost; where all was in sorrow and dismay. No exertions of theirs could rally the dispersed, or skill prevent the fatal consequences. At the present day, the seminary of Olinda, in comparison with the former Jesuits' college, is only as the waning moon's beam to the sun's meridian splendour.

When you visit the places where those learned fathers once flourished, and see with your own eyes the evils their dissolution has caused; when you hear the inhabitants telling you how good, how clever, how charitable they were; what will you think of our poet laureate for calling them, 


\section{WANDERINGS IN SOUTH AMERICA}

in his "History of Brazil," "Missioners, whose zeal the most fanatical was directed by the coolest policy"'?

Was it fanatical to renounce the honours and comforts of this transitory life, in order to gain eternal glory in the next, by denying themselves, and taking up the cross? Was it fanatical to preach salvation to innumerable wild hordes of Americans? to clothe the naked? to encourage the repenting simner? to aid the dying Christian? The fathers of the Society of Jesus did all this. And for this their zeal is pronounced to be the most fanatical, directed by the coolest policy. It will puzzle many a clear brain to comprehend how it is possible, in the nature of things, that zeal the most fanatical should be directed by the coolest policy. Ah, Mr. Laureate, Mr. Laureate, that "quidlibet audendi" of yours, may now and then gild the poet, at the same time that it makes the historian cut a sorry figure!

Could Father Nobrega rise from the tomb, he would thus address you:- "Ungrateful Englishman, you have drawn a great part of your information from the writings of the Society of Jesus, and in return you attempt to stain its character by telling your countrymen that 'we taught the idolatry we believed!' In speaking of me, you say, it was my happy fortune to be stationed in a country where none but the good principles of my order were called into action. Ungenerous laureate, the narrow policy of the times has kept your countrymen in the dark with regard to the true character of the Society of Jesus; and you draw the bandage still tighter over their eyes by 
a malicious insinuation. I lived, and tanght, and died in Brazil, where you state that none but the good principles of my order were called into action, and still, in most absolute contradiction to this, you remark we believed the idolatry we taught in Brazil. Thus we brought none but good principles into action, and still taught idolatry! "Again, you state there is no individual to whose talents Brazil is so greatly and permanently indebted as mine, and that I must be regarded as the founder of that system so successfully pursued by the Jesuits in Paraguay; a system productive of as much good as is compatible with pious fraud. Thus you make me, at one and the same time, a teacher of none but good principles, and a teacher of idolatry, and a believer in idolatry, and still the founder of a system for which Brazil is greatly and permanently indebted to me, though, by the by, the system was only productive of as much good as is compatible with pious fraud!

"What means all this? After reading such incomparable nonsense, should your countrymen wish to be properly informed concerning the Society of Jesus, there are in England documents enough to show that the system of the Jesuits was a system of Christian charity towards their fellow-creatures, administered in a manner which human prudence judged best calculated to ensure success; and that the idolatry which you uncharitably affirm they tanght, was really and truly the very same faith which the Catholic Church tanght for centuries in England, which she still teaches to those who wish to hear her, and which she will 


\section{WANDERINGS IN SOUTH AMERICA}

continue to teach, pure and unspotted, till time shall be no more."

The environs of Pernambuco are very pretty. You see country houses in all directions, and the appearance of here and there a sugar plantation enriches the scenery. Palm-trees, Cocoa-nuttrees, Orange and Lemon groves, and all the different fruits peculiar to Brazil, are here in the greatest abundance.

At Olinda there is a national botanical garden; it wants space, produce, and improvement. The forests, which are several leagues off, abound with birds, beasts, insects, and serpents. Besides a brilliant plumage, many of the birds have a very fine song. The Troupiale, noted for its rich colours, sings delightfully in the environs of Pernambnco. The Red-headed Finch, larger than the European sparrow, pours forth a sweet and varied strain, in company with two species of wrens, a little before daylight. There are also several species of the thrush, which have a song somewhat different from that of the European thrush; and two species of the linnet, whose strain is so soft and sweet that it dooms them to captivity in the liouses. A bird called here Sangre do Buey, blood of the ox, cannot fail to engage your attention; he is of the passerine tribe, and very common abont the houses; the wings and tail are black, and every other part of the body a flaming red. In Guiana, there is a species exactly the same as this in shape, note, and economy, but different in colour, its whole body being like black velvet; on its breast a tinge of red appears through the black. Thus nature has ordered this 
little Tangara to put on mourning to the north of the line, and wear scarlet to the south of it.

For three months in the year the environs of Pernambuco are animated beyond description. From November to March the weather is particularly fine; then it is that rich and poor, young and old, foreigners and natives, all issue from the city to enjoy the country, till Lent approaches, when back they hie them. Villages and hamlets, where nothing before but rags was seen, now shine in all the elegance of dress; every house, every room, every shed becomes eligible places for those whom nothing but extreme necessity could have forced to live there a few weeks ago: some join in the merry dance, others saunter up and down the orange-groves; and towards evening the roads become a moving scene of silk and jewels. The gaming-tables have constant visitors; there, thousands are daily and nightly lost and won; parties even sit down to try their luck round the outside of the door as well as in the room:-

\footnotetext{
"Vestibulum ante ipsum primisque in faucibus aulæ Luctus et ultrices, posuere sedilia curæ.",
}

About six or seven miles from Pernambuco stands a pretty little village called Monteiro; the river runs close by it, and its rural beauties seem to surpass all others in the neighbourhood; there the Captain-General of Pernambuco resides during this time of merriment and joy.

The traveller who allots a portion of his time to peep at his fellow-creatures in their relaxations, and accustoms himself to read their several little histories in their looks and gestures as he goes 
musing on, may have full occupation for an hour or two every day at this season amid the variegated scenes round the pretty village of Monteiro. In the evening groups sitting at the door, he may sometimes see with a sigh how wealth and the prince's favour cause a booby to pass for a Solon, and be reverenced as such, while perhaps a poor, neglected Camoens stands silent at a distance, awed by the dazzling glare of wealth and power. Retired from the public road he may see poor Maria sitting under a palm-tree, with her elbow in her lap, and her head leaning on one side within her hand, weeping over her forbidden bans. And as he moves on "with wandering step and slow," he may hear a broken-hearted nymph ask her faithless swain,-

"How could you say my face was fair, And yet that face forsake?

How could you win my virgin heart,

Yet leave that heart to break?"'

One afternoon, in an unfrequented part not far from Monteiro, these adventures were near being brought to a speedy and a final close: six or seven blackbirds, with a white spot betwixt the shoulders, were making a noise, and passing to and fro on the lower branches of a tree in an abandoned, weed-grown, orange orchard. In the long grass underneath the tree, apparently a pale green grasshopper was fluttering, as though it had got entangled in it. When you once fancy that the thing you are looking at is really what you take it for, the more you look at it the more you are convinced that it is so. In the present case, this was 


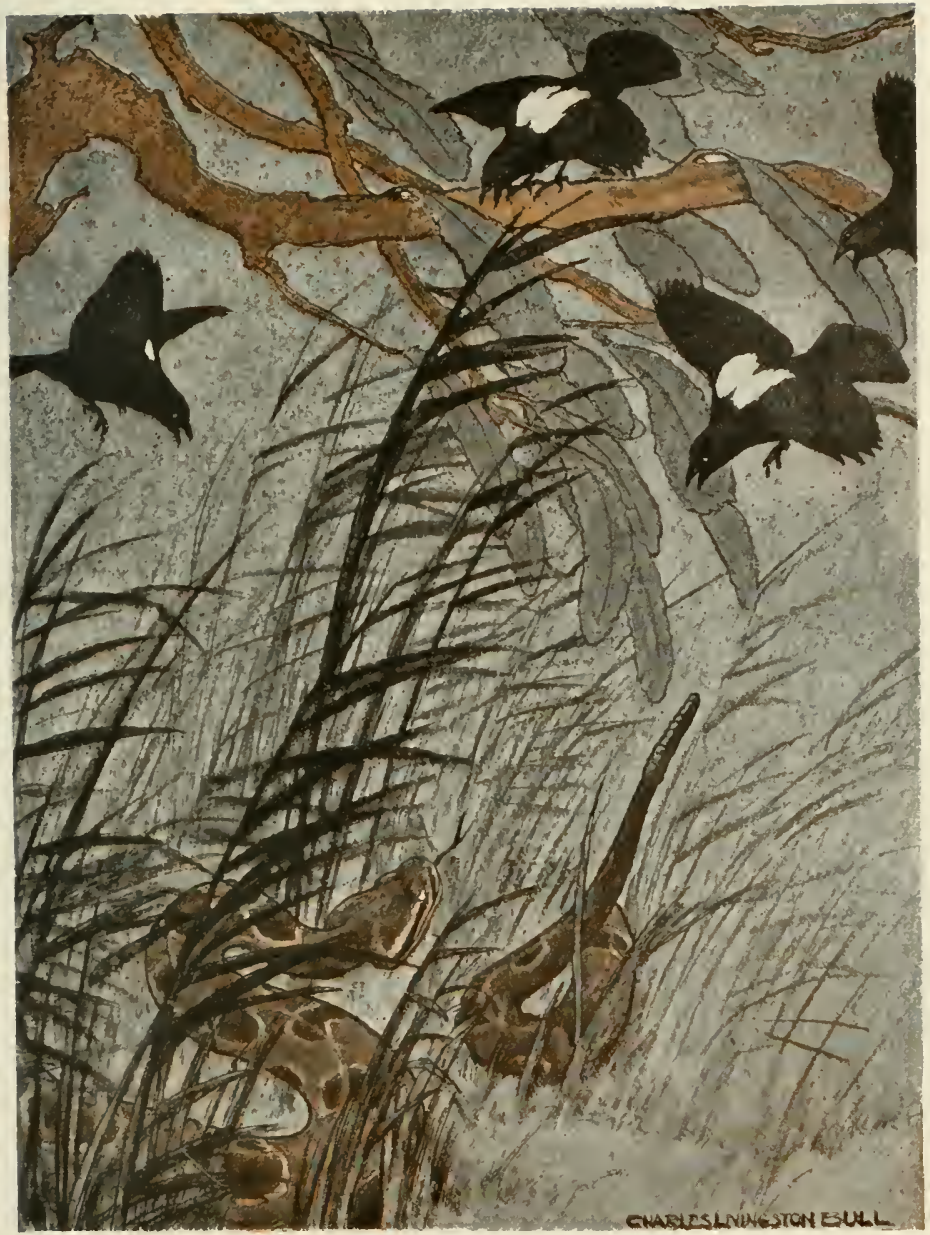

Blackhirds and Rattle-snake 

a grasshopper beyond all doubt, and nothing more remained to be done but to wait in patience till it had settled, in order that you might run no risk of breaking its legs in attempting to lay hold of it while it was fluttering-it still kept fluttering; and having quietly approached it, intending to make sure of it-behold, the head of a large rattlesnake appeared in the grass close by: an instantaneous spring backwards prevented fatal consequences. What had been taken for a grasshopper was, in fact, the elevated rattle of the snake in the act of announcing that he was quite prepared, though unwilling, to make a sure and deadly spring. He shortly after passed slowly from under the orange-tree to the neighbouring wood on the side of a hill: as he moved over a place bare of grass and weeds, he appeared to be about eight feet long; it was he who had engaged the attention of the birds, and made them heedless of danger from another quarter: they flew away on his retiring; one alone left lis little life in the air, destined to become a specimen, mute and motionless, for the inspection of the curious in a far distant clime.

It was now the rainy season; the birds were moulting; fifty-eight specimens of the handsomest of them in the neighbourhood of Pernambuco had been collected; and it was time to proceed elsewhere. The conveyance to the interior was by horses; and this mode, together with the heavy rains, would expose preserved specimens to almost certain damage. The journey to Maranham by land would take at least forty days. The route was not wild enough to 


\section{WANDERINGS IN SOUTH AMERICA}

engage the attention of an explorer, or civilized enough to afford common comforts to a traveller. By sea there were no opportunities, except slave ships. As the transporting poor negroes from port to port for sale pays well in Brazil, the ships' decks are crowded with them. This would not do.

Excuse here, benevolent reader, a small tribute of gratitude to an Irish family, whose urbanity and goodness have long gained it the esteem and respect of all ranks in Pernambuco. The kindness and attention I received from Dennis Kearney, Esq., and his amiable lady, will be remembered with gratitude to my dying day.

After wishing farewell to this hospitable family, I embarked on board a Portuguese brig, with poor accommodation, for Cayenne in Guiana. The most eligible bedroom was the top of a lien-coop on deck. Even here, an unsavoury little beast, called bug, was neither shy nor deficient in appetite.

The Portuguese seamen are famed for catching fish. One evening, under the line, four sharks made their appearance in the wake of the vessel. The sailors caught them all. 


\section{CHAPTER II}

On the fourteenth day after leaving Pernambuco, the brig cast anchor off the island of Cayenne. The entrance is beautiful. To windward, not far off, there are two bold wooded islands, called the Father and Mother; and near them are others, their children, smaller, though as beautiful as their parents. Another is seen a long way to leeward of the family, and seems as if it had strayed from home, and cannot find its way back. The French call it "l'enfant perdu." As you pass the islands, the stately hills on the main, ornamented with ever-verdant foliage, show you that this is by far the sublimest scenery on the sea-coast, from the Amazons to the Oroonoque. On casting your eye towards Dutch Guiana, you will see that the mountains become unconnected and few in number, and long before you reach Surinam the Atlantic wave washes a flat and muddy shore.

Considerably to windward of Cayenne, and about twelve leagues from land, stands a stately and towering rock, called the Constable. As nothing grows on it to tempt greedy and aspiring man to claim it as his own, the sea-fowl rest and raise their offspring there. The bird called the Frigate is ever soaring round its rugged summit. Hither the Phaeton bends his rapid flight, and flocks of rosy Flamingos here defy the fowler's cunning. 


\section{WANDERINGS IN SOUTH AMERICA}

All along the coast, opposite the Constable, and indeed on every uncultivated part of it to windward and leeward, are seen innumerable quantities of Snow-white Egrets, Scarlet Curlews, Spoonbills, and Flamingos.

Cayenne is capable of being a noble and productive colony. At present it is thought to be the poorest on the coast of Guiana. Its estates are too much separated one from the other by immense tracts of forest; and the revolutionary war, like a cold eastern wind, has chilled their zeal and blasted their best expectations.

The Clove-tree, the Cinnamon, Pepper and Nutmeg, and many other choice spices and fruits of the eastern and Asiatic regions, produce abundantly in Cayenne.

The town itself is prettily laid out, and was once well fortified. They tell you it might easily have been defended against the invading force of the two united nations; but Victor Hugues, its governor, ordered the tri-coloured flag to be struck; and ever since that day the standard of Braganza has waved on the ramparts of Cayenne.

He who has received humiliations from the hand of this haughty, iron-hearted governor, may see him now in Cayenne, stripped of all his revolutionary honours, broken down and ruined, and under arrest in his own house. He has four accomplished daughters, respected by the whole town. Towards the close of day, when the sun's rays are no longer oppressive, these much-pitied ladies are seen walking up and down the balcony with their aged parent, trying, by their kind and 


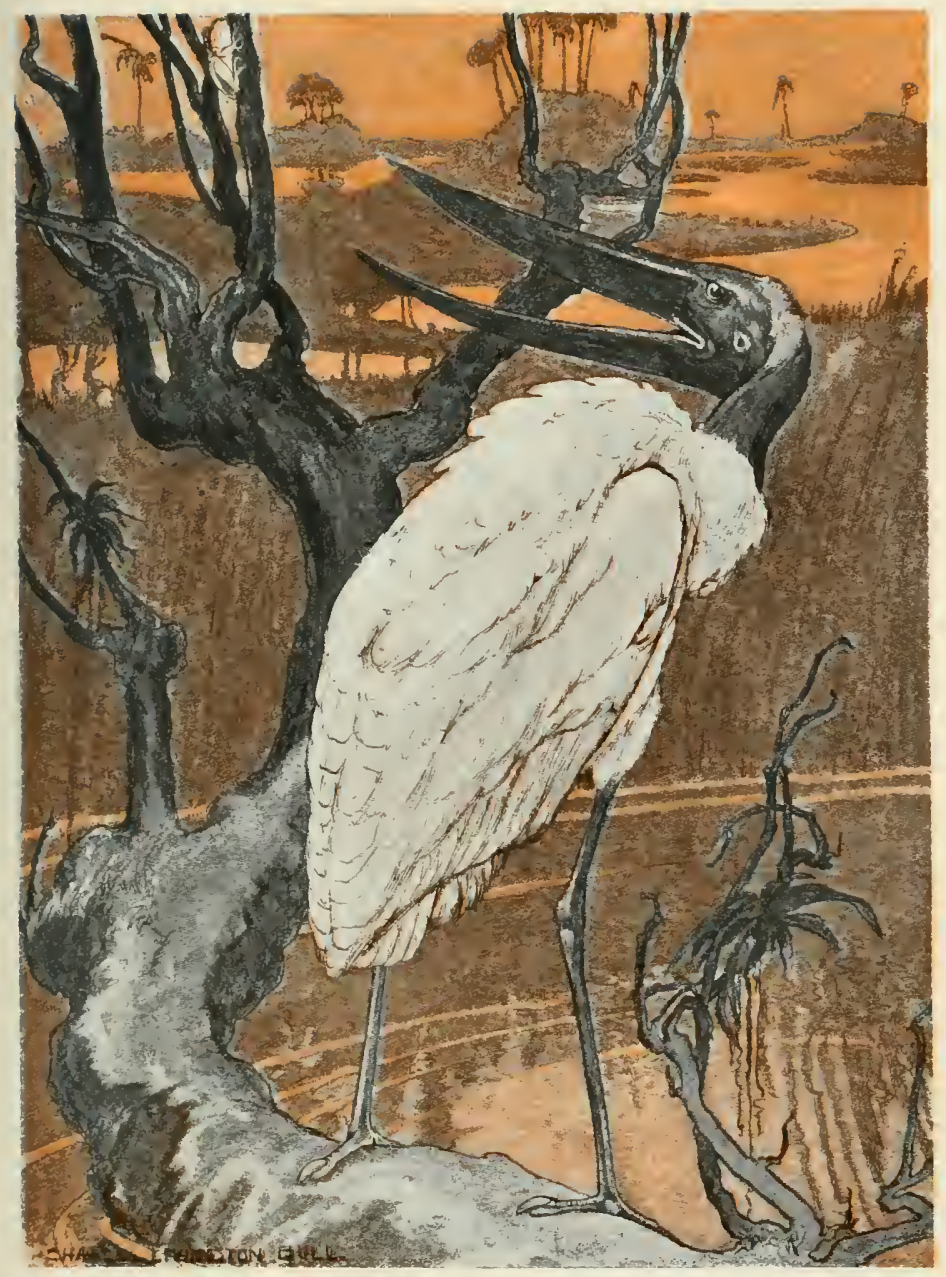

The Egret 

filial attention, to remove the settled gloom from his too guilty brow.

This was not the time for a traveller to enjoy Cayenne. The hospitality of the inhabitants was the same as ever, but they had lost their wonted gaiety in public, and the stranger might read in their countenances, as the recollection of recent humiliations and misfortunes every now and then kept breaking in upon them, that they were still in sorrow for their fallen country: the victorious hostile cannon of Waterloo still sounded in their ears: their Emperor was a prisoner amongst the hideous rocks of St. Helena; and many a Frenchman who had fought and bled for France was now amongst them, begging for a little support to prolong a life which would be forfeited on the parent soil. To add another handful to the cypress and wormwood already scattered amongst these polite colonists, they had just received orders from the court of Janeiro to put on deep mourning for six months, and half-mourning for as many more, on account of the death of the Queen of Portugal.

About a day's journey in the interior is the celebrated national plantation. This spot was judiciously chosen, for it is out of the reach of enemies' cruisers. It is called La Gabrielle. No plantation in the western world can vie with La Gabrielle. Its spices are of the choicest kind; its soil particularly favourable to them; its arrangements beautiful; and its directeur, Monsieur Martin, a botanist of first-rate abilities. This indefatigable naturalist ranged through the East, under a royal commission, in quest of botanical knowledge; and during his stay in the western 
regions has sent over to Europe from twenty to twenty-five thousand specimens, in botany and zoölogy. La Gabrielle is on a far-extending range of woody hills. Figure to yourself a hill in the shape of a bowl reversed, with the buildings on the top of it, and you will have an idea of the appearance of La Gabrielle. You approach the house through a noble avenue, five hundred toises long, of the choicest tropical fruit-trees, planted with the greatest care and judgment; and should you chance to stray throwgh it, after sunset, when the clove-trees are in blossom, you would fancy yourself in the Idalian groves, or near the banks of the Nile, where they were burning the finest incense as the Queen of Egypt passed.

On La Gabrielle there are twenty-two thousand clove-trees in full bearing. They are planted thirty feet asunder. Their lower branches touch the ground. In general the trees are topped at five-and-twenty feet high; though you will see some here towering up above sixty. The black pepper, the cinnamon, and nutmeg are also in great abundance here, and very productive.

While the stranger views the spicy groves of La Gabrielle, and tastes the most delicious fruits which have been originally imported hither from all parts of the tropical world, he will thank the government which has supported, and admire the talents of the gentleman who has raised to its present grandeur, this noble collection of useful fruits. There is a large nursery attached to La Gabrielle, where plants of all the different species are raised and distributed gratis to those colonists who wish to cultivate them. 
Not far from the banks of the river Oyapoc, to windward of Cayenne, is a mountain which contains an immense cavern. Here the Cock of the Rock is plentiful. He is about the size of a fantail pigeon, his colour a bright orange, and his wings and tail appear as though fringed; his head is ornamented with a superb double-feathery crest, edged with purple. He passes the day amid gloomy damps and silence, and only issues out for food a short time at sunrise and sunset. He is of the gallinaceous tribe. The South-American Spaniards call him "Gallo del Rio Negro," (Cock of the Black River,) and suppose that he is only to be met with in the vicinity of that far-inland stream; but he is common in the interior of Demerara, amongst the huge rocks in the forests of Macoushia; and he has been shot south of the line, in the captainship of Para.

The bird called by Buffon Grand Gobe-mouche has never been found in Demerara, although very common in Cayenne $\mathrm{He}$ is not quite so large as the jackdaw, and is entirely black, except a large spot under the throat, which is a glossy purple.

You may easily sail from Cayenne to the river Surinam in two days. Its capital, Paramaribo, is handsome, rich and populous: hitherto it has been considered by far the finest town in Guiana; but probably the time is not far off when the capital of Demerara may claim the prize of superiority. You may enter a creek above Paramaribo, and travel through the interior of Surinam, till you come to the Nicari, which is close to the large river Coryntin. When you have passed this river, 


\section{WANDERINGS IN SOUTH AMERICA}

there is a good public road to New Amsterdam, the capital of Berbice.

On viewing New Amsterdam, it will immediately strike you that something or other has intervened to prevent its arriving at that state of wealth and consequence for which its original plan shows it was once intended. What has caused this stop in its progress to the rank of a fine and populous city remains for those to find out who are interested in it; certain it is, that New Amsterdam has been languid for some years, and now the tide of commerce seems ebbing fast from the shores of Berbice.

Gay and blooming is the sister colony of Demerara. Perhaps, kind reader, thou hast not forgot that it was from Stabroek, the capital of Demerara, that the adventurer set out, some years ago, to reach the Portuguese frontier fort, and collect the wourali-poison. It was not intended, when this second sally was planned in England, to have visited Stabroek again by the route here described. The plan was to have ascended the Amazons from Para and got into the Rio Negro, and from thence to have returned towards the source of the Essequibo, in order to examine the crystal mountains, and look once more for Lake Parima, or the White Sea; but on arriving at Cayenne, the current was running with such amazing rapidity to leeward, that a Portuguese sloop, which had been beating up towards Para for four weeks, was then only half way. Finding, therefore, that a beat to the Amazons would be long, tedious, and even uncertain, and aware that the season for procuring birds in fine plumage had already set 
in, I left Cayenne in an American ship for Paramaribo, went through the interior to the Coryntin, stopped a few days in New Amsterdam, and proceeded to Demerara. If, gentle reader, thy patience be not already worn out, and thy eyes half closed in slumber, by perusing the dull adventures of this second sally, perhaps thou wilt pardon a line or two on Demerara; and then we will retire to its forests, to collect and examine the economy of its most rare and beautiful birds, and give the world a new mode of preserving them.

Stabroek, the capital of Demerara, has been rapidly increasing for some years back; and if prosperity go hand in hand with the present enterprising spirit, Stabroek, ere long, will be of the first colonial consideration. It stands on the eastern bank at the mouth of the Demerara, and enjoys all the advantages of the refreshing seabreeze; the streets are spacious, well bricked and elevated, the trenches clean, the bridges excellent, and the houses handsome. Almost every commodity and luxury of London may be bought in the shops at Stabroek: its market wants better regulations. The hotels are commodious, clean, and well attended. Demerara boasts as fine and well-disciplined militia as any colony in the western world.

The court of justice, where, in times of old, the bandage was easily removed from the eyes of the goddess, and her scales thrown out of equilibrium, now rises in dignity under the firmness, talents, and urbanity of Mr. President Rough.

The plantations have an appearance of high cultivation; a tolerable idea may be formed of 


\section{IVANDERINGS IN SOUTIY 'AMERICA}

their value when you know that last year Demerara numbered seventy-two thousand nine humdred and ninety-nine slaves. They made about forty-four million pounds of sugar, near two million gallons of rum, above eleven million pounds of coffee, and three million eight hundred and nineteen thousand five hundred and twelve pounds of cotton; the receipt into the public chest was five hundred and fifty-three thousand nine hundred and fifty-six guilders; the public expenditure, four liundred and fifty-one thousand six hundred and three guilders.

Slavery can never be defended; he whose heart is not of iron can never wish to be able to defend it: while he heaves a sigh for the poor negro in captivity, he wishes from his soul that the traffic had been stifled in its birth; but, unfortunately, the governments of Europe nourished it, and now they are exerting themselves to do away the evil, and ensure liberty to the sons of Africa, the situation of the plantation slaves is depicted as truly deplorable, and their condition wretched. It is not so. A Briton's heart, proverbially kind and generous, is not changed by climate, or its streams of compassion dried up by the scorching heat of a Demerara sun; he cheers his negroes in labour, comforts them in sickness, is kind to them in old age, and never forgets that they are his fellow-creatures.

Instances of cruelty and depravity certainly occur here as well as all the world over; but the edicts of the colonial government are well calculated to prevent them; and the British planter, except here and there one, feels for the wrongs 
done to a poor ill-treated slave, and shows that his heart grieves for him by causing immediate redress, and preventing a repetition.

Long may ye flourish, peaceful and liberal inhabitants of Demerara! Your doors are ever open to harbour the harbourless; your purses never slut to the wants of the distressed: many a ruined fugitive from the Oroonoque will bless your kindness to him in the hour of need, when flying from the woes of civil discord, without food or raiment, he begged for shelter underneath your roof. The poor sufferer in Trinidad, who lost his all in the devouring flames, will remember your charity to his latest moments. The traveller, as he leaves your port, casts a longing, lingering look behind; your attentions, your hospitality, your pleasantry and mirtl, are uppermost in his thoughts: your prosperity is close to his heart. Let us now, gentle reader, retire from the busy scenes of man, and journey on towards the wilds in quest of the feathered tribe.

Leave behind you your high-seasoned dishes, your wines and your delicacies; carry nothing but what is necessary for your own comfort and the object in view, and depend upon the skill of the Indian, or your own, for fish and game. A sheet, about twelve feet long, ten wide, painted, and with loop-holes on each side, will be of great service; in a few minutes you can suspend it betwixt two trees in the shape of a roof. Under this, in your hammock, you may defy the pelting shower, and sleep heedless of the dews of night. A hat, a shirt, and a light pair of trousers, will be all the raiment you require. Custom will soon 


\section{WANDERINGS IN SOUTH AMERICA}

teach you to tread lightly and barefoot on the little inequalities of the ground, and show you how to pass on, unwounded, amid the mantling briers.

Snakes in these wilds are certainly an annoyance, though perhaps more in imagination than reality; for you must recollect that the serpent is never the first to offend; his poisonous fang was not given him for conquest: he never inflicts a wound with it but to defend existence. Provided you walk cautiously, and do not absolutely touch him, you may pass in safety close by him. As he is often coiled up on the ground, and amongst the branches of the trees above you, a degree of circumspection is necessary, lest you unwarily disturb him.

Tigers are too few, and too apt to fly before the noble face of man, to require a moment of your attention.

The bite of the most noxious of the insects, at the very worst, only causes a transient fever, with a degree of pain more or less.

Birds in general, with few exceptions, are not common in the very remote parts of the forest. The sides of rivers, lakes, and creeks, the borders of savannas, the old abandoned habitations of Indians and woodcutters, seem to be their favourite haunts.

Though least in size, the glittering mantle of the Humming-bird entitles it to the first place in the list of the birds of the new world. It may truly be called the Bird of Paradise; and had it existed in the old world, it would have claimed the title instead of the bird which has now the honour 
to bear it:- see it darting through the air almost as quick as thought!- now it is within a yard of your face!-in an instant gone!-now it flutters from flower to flower to sip the silver dew-it is now a ruby-now a topaz-now an emerald-now all burnished gold! It would be arrogant to pretend to describe this winged gem of nature after Buffon's elegant description of it.

Cayenne and Demerara prodnce the same humming-birds. Perhaps you would wish to know something of their haunts. Chiefly in the months of July and August the tree called Bois Immortel, very common in Demerara, bears abundance of red blossom, which stays on the tree some weeks; then it is that most of the different species of humming-birds are very plentiful. The wild red sage is also their favourite shrub, and they buzz like bees round the blossoms of the wallaba-tree. Indeed, there is scarce a flower in the interior, or on the sea-coast, but what receives frequent visits from one or other of the species.

On entering the forests, on the rising land in the interior, the blue and green, the smallest brown, no bigger than the humblebee, with two long feathers in the tail, and the little forked-tail purple-throated humming-birds, glitter before you in ever-changing attitudes. One species alone never shows his beauty to the sun; and were it not for his lovely shining colours, you might almost be tempted to class him with the goatsuckers on acconnt of his habits. He is the largest of all the humming-birds, and is all red and changing gold green, except the head, which is black. He has two long feathers in the tail, which cross each 


\section{WANDERINGS IN SOUTH AMERICA}

other, and these have gained him the name of Karabimiti, or Ara hnmming-bird, from the Indians. You never find him on the sea-coast, or where the river is salt, or in the heart of the forest, unless fresh water be there. He keeps close by the side of woody fresh-water rivers and dark and lonely creeks. He leaves his retreat before sunrise to feed on the insects over the water; he returns to it as soon as the sun's rays cause a glare of light, is sedentary all day long, and comes out again for a short time after sunset. He builds his nest on a twig over the water in the unfrequented creeks; it looks like tanned cow-leather.

As you advance towards the mountains of Demerara, other species of humming-birds present themselves before you. It seems to be an erroneous opinion that the humming-bird lives entirely on honey-dew. Almost every flower of the tropical climate contains insects of one kind or other; now, the humming-bird is most busy about the flowers an hour or two after sumrise and after a shower of rain, and it is just at this time that the insects come out to the edge of the flower in order that the sun's rays may dry the nocturnal dew and rain which they have received. On opening the stomach of the humming-bird, dead insects are almost always found there.

Next to the humming-birds, the Cotingas display the gayest plumage. They are of the order of Passeres, and yon number five species betwixt the sea-coast and the rock Saba. Perhaps the Scarlet Cotinga is the richest of the five, and is one of those birds which are found in the deepest recesses of the forest. His crown is flaming red; 
to this abruptly succeeds a dark shining brown, reaching half way down the back: the remainder of the back, the rump, and tail, the extremity of which is edged with black, are a lively red; the belly is a somewhat lighter red; the breast reddish black; the wings brown. He has no song, is solitary, and utter's a monotonous whistle which sounds like "quet." He is fond of the seeds of the hitia-tree, and those of the siloabali and bastard-siloabali trees, which ripen in December, and continue on the trees for above two months. He is found throughout the year in Demerara; still nothing is known of his incubation. The Indians all agree in telling you that they have never seen his nest.

The Purple-breasted Cotinga has the throat and breast of a deep purple, the wings and tail black, and all the rest of the body a most lovely shining blue.

The Purple-throated Cotinga has black wings and tail, and every other part a light and glossy blue, save the throat, which is purple.

The Pompadour Cotinga is entirely purple, except his wings, which are white, their four first feathers tipped with brown. The great coverts of the wings are stiff, narrow, and pointed, being shaped quite different from those of any other bird. When you are betwixt this bird and the sun in his flight, he appears uncommonly brilliant. He makes a hoarse noise, which sounds like "Wallababa." Hence his name amongst the Indians.

None of these three cotingas have a song. They feed on the hitia, siloabali, and bastard-siloabali seeds, the wild guava, the fig, and other fruit 


\section{WANDERINGS IN SOUTH AMERICA}

trees of the forest. They are easily shot in these trees during the months of December, January, and part of February. The greater part of them disappear after this, and probably retire far away to breed. Their nests have never been found in Demerara.

The fifth species is the celebrated Campanero of the Spaniards, called Dara by the Indians, and Bell-bird by the English. He is about the size of the jay. His plumage is white as snow. On his forehead rises a spiral tube nearly three inches long. It is jet black, dotted all over with small white feathers. It has a communication with the palate, and when filled with air looks like a spire; when empty it becomes pendulous. His note is loud and clear, like the sound of a bell, and may be heard at the distance of three miles. In the midst of these extensive wilds, generally on the dried top of an ancient mora, almost out of gun reach, you will see the campanero. No sound or song from any of the winged inhabitants of the forest, not even the clearly pronounced "Whippoor-Will," from the goatsucker, cause such astonishment as the toll of the campanero.

With many of the feathered race, he pays the common tribute of a morning and an evening song; and even when the meridian sun has shut in silence the mouths of almost the whole of animated nature, the campanero still cheers the forest. You hear his toll, and then a pause for a minute, then another toll, and then a pause again, and then a toll, and again a pause. Then he is silent for six or eight minutes, and then another toll, and so on. Acteon would stop in mid chace, 
Maria would defer her evening song, and Orpheus himself would drop his lute to listen to him, so sweet, so novel, and romantic is the toll of the pretty snow-white campanero. He is never seen to feed with the other cotingas, nor is it known in what part of Guiana he makes his nest.

While the cotingas attract your attention by their superior plumage, the singular form of the Toucan makes a lasting impression on your memory. There are three species of toucans in Demerara, and three diminutives, which may be called Toucanets. The largest of the first species frequents the mangrove-trees on the sea-coast. $\mathrm{He}$ is never seen in the interior till you reach Macoushia, where he is found in the neighbourhood of the river Tacatou. The other two species are very common. They feed entirely on the fruits of the forest, and though of the pie kind, never kill the young of other birds or touch carrion. The larger is called Bouradi by the Indians, (which means Nose,) the other, Scirou. They seem partial to each other's company, and often resort to the same feeding tree, and retire together to the same shady noon-day retreat. They are very noisy in rainy weather at all hours of the day, and in fair weather, at morn and eve. The sound which the bouradi makes is like the clear yelping of a puppy dog, and you fancy he says "Pia-po-oco," and thus the South American Spaniards call him Piapoco.

All the toucanets feed on the same trees on which the toucan feeds, and every species of this family of enormous bill, lays it eggs in the hollow trees. They are social, but not gregarious. You 
may sometimes see eight or ten in company, and from this you would suppose they are gregarious; but, upon a closer examination, you will find it has only been a dinner party, which breaks up and disperses towards roosting-time.

You will be at a loss to conjecture for what ends nature has overloaded the head of this bird with such an enormous bill. It cannot be for the offensive, as it has no need to wage war with any of the tribes of animated nature; for its food is fruit and seeds, and those are in superabundance throughout the whole year in the regions where the toucan is found. It can hardly be for the defensive, as the toucan is preyed upon by no bird in South America, and were it obliged to be at war, the texture of the bill is ill adapted to give or receive blows, as you will see in dissecting it. It cannot be for any particular protection to the tongue, as the tongue is a perfect feather.

The flight of the toucan is by jerks; in the action of flying it seems incommoded by this liuge disproportioned feature, and the head seems as if bowed down to the earth by it against its will; if the extraordinary form and size of the bill expose the toucan to ridicule, its colours make it amends. Were a specimen of each species of the toucan presented to you, you would pronounce the bill of the bouradi the most rich and beautiful; on the ridge of the upper mandible a broad stripe of most lovely yellow extends from the head to the point; a stripe of the same breadth, though somewhat deeper yellow, falls from it at right angles next the head down to the edge of the mandible; then follows a black stripe, half as broad, 

falling at right angles from the ridge, and running narrower along: the edge to within half an inch of the point. The rest of the mandible is a deep bright red. The lower mandible has no yellow: its black and red are distributed in the same manner as on the upper one, with this difference, that there is black about an inch from the point. The stripe corresponding to the deep yellow stripe on the upper mandible is sky blue. It is worthy of remark that all these brilliant colours of the bill are to be found in the plumage of the body, and the bare skin round the eye.

All these colours, except the blue, are inherent in the horn; that part which appears blne is in reality transparent white, and receives its colour from a thin piece of blue skin inside. This superb bill fades in death, and in three or four days' time has quite lost its original colours.

Till within these few years, no idea of the true colours of the bill could be formed from the stuffed toucans brought to Europe. About eight years ago, while eating a boiled toncan, the thought struck me that the colours in the bill of a preserved specimen might be kept as bright as those in life. A series of experiments proved this beyond a doubt. If you take your penknife and cut away the roof of the upper mandible, you will find that the space betwixt it and the onter shell contains a large collection of veins, and small osseous fibres running in all directions through the whole extent of the bill. Clear away all these with your knife, and you will come to a substance more firm than skin, but of not so strong a texture as the horn itself; cut this 
away also, and behind it is discovered a thin and tender membrane; yellow, where it has touched the yellow part of the horn; blue, where it has touched the red part, and black towards the edge and point; when dried, this thin and tender membrane becomes nearly black; as soon as it is cut away, nothing remains but the outer horn, red and yellow, and now become transparent; the under mandible must undergo the same operation. Great care must be taken, and the knife used very cantiously when you are cutting through the different parts close to where the bill joins on to the head; if you cut away too much, the bill drops off; if you press too hard, the knife comes through the horn; if you leave too great a portion of the membrane, it appears through the horn, and by becoming black when dried, makes the horn appear black also, and has a bad effect; judgment, caution, skill, and practice, will insure success.

You have now cleared the bill of all those bodies which are the cause of its apparent fading; for, as has been said before, these bodies dry in death, and become quite discoloured, and appear so through the horn; and reviewing the bill in this state, you conclude that its former bright colours are lost.

Something still remains to be done. You have rendered the bill transparent by the operation, and that transparency must be done away to make it appear perfectly natural. Pound some clean chalk, and give it enough water till it be of the consistency of tar; add a proportion of gunarabic to make it adhesive; then take a camel- 
hair brush, and give the inside of both mandibles a coat; apply a second when the first is dry, then another, and a fourth to finish all. The gumarabic will prevent the chalk from cracking and falling off. If you remember, there is a little space of transparent white in the lower mandible, which originally appeared blue, but which became transparent white as soon as the thin piece of blue skin was cut away; this must be painted blue inside. When all this is completed, the bill will please you; it will appear in its original colours. Probably your own abilities will suggest a cleverer mode of operating than the one here described. A small gouge would assist the penknife, and render the operation less difficult. 


\section{CHAPTER III}

The Houtou ranks high in beauty amongst the birds of Demerara-lis whole body is green, with a bluish east in the wings and tail; his crown, which he erects at pleasure, consists of black in the centre, surrounded with lovely blue of two different shades: he has a triangular black spot, edged with blue, behind the eye extending to the ear; and on his breast a sable tuft, consisting of nine feathers edged also with blue. This bird seems to suppose that its beauty can be increased by trimming the tail, which undergoes the same operation as our hair in a barber's shop, only with this difference, that it uses its own beak, which is serrated, in lieu of a pair of scissors; as soon as his tail is full grown, he begins about an inch from the extremity of the two longest feathers in it, and cuts away the web on both sides of the shaft, making a gap about an inch long: both male and female Adonise their tails in this manner, which gives them a remarkable appearance amongst all other birds. While we consider the tail of the houtou blemished and defective, were he to come amongst us, he would probably consider our heads, cropped and bald, in no better light. He who wishes to observe this handsome bird in his native haunts, must be in the forest at the morning's dawn. The houtou shuns the society of man: the plantations and cultivated parts 
are too much disturbed to engage it to settle there; the thick and gloomy forests are the places preferred by the solitary houtou. In those farextending wilds, about daybreak, you hear him articulate, in a distinct and mournful tone, "Houtou, houtou." Move cautious on to where the sound proceeds from, and you will see him sitting in the underwood, about a couple of yards from the ground, his tail moving up and down every time he articulates "houtou." He lives on insects and the berries amongst the underwood, and very rarely is seen in the lofty trees, except the bastard-siloabali tree, the fruit of which is grateful to him. He makes no nest, but rears his young in a hole in the sand, generally on the side of a hill.

While in quest of the houtou, you will now and then fall in with the Jay of Guiana, called by the Indians Ibibirou. Its forehead is black, the rest of the head white; the throat and breast like the English magpie: about an inch of the extremity of the tail is white, the other part of it, together with the back of the wings, a greyish changing purple; the belly is white: there are generally six or eight of them in company; they are shy and garrulous, and tarry a very short time in one place; they are never seen in the cultivated parts.

Through the whole extent of the forest, chiefly from sunrise till rine o'clock in the morning, you hear a sound of "Wow, wow, wow, wow." 'This is the bird called Boclora by the Indians. It is smaller than the common pigeon, and seems, in some measure, to partake of its nature: its head and breast are blue; the back and rump somewhat 


\section{WANDERINGS IN SOUTH AMERICA}

resemble the colour on the peacock's neck; its belly is a bright yellow; the legs are so very short that it always appears as if sitting on the branch; it is as ill-adapted for walking as the swallow; its neck, for above an inch all round, is quite bare of feathers, but this deficiency is not seen, for it always sits with its head drawn in upon its shoulders: it sometimes feeds with the cotingas on the guava and hitia trees; but its chief nutriment seems to be insects, and, like most birds which follow this prey, its chaps are well armed with bristles: it is found in Demerara at all times of the year, and makes a nest resembling that of the stock-dove. This bird never takes long flights, and when it crosses a river or creek it goes by long jerks.

The boclora is very unsuspicious, appearing quite heedless of danger: the report of a gun within twenty yards will not cause it to leave the branch on which it is sitting, and you may often approach it so near as almost to touch it with the end of your bow. Perhaps there is no bird known whose feathers are so slightly fixed to the skin as those of the boclora. After shooting it, if it touch a branch in its descent, or if it drop on hard ground, whole heaps of feathers fall off; on this account it is extremely hard to procure a specimen for preservation. As soon as the skin is dry in the preserved specimen, the seathers become as well fixed as those in any other bird.

Another species, larger than the boclora, attracts much of your notice in these wilds; it is called Cuia by the Indians, from the sound of its voice; its habits are the same as those of the 
boclora, but its colours different; its head, breast, back, and rump, are a shining, changing green; its tail not quite so bright; a black bar runs across the tail towards the extremity, and the outside feathers are partly white, as in the boclora; its belly is entirely vermilion, a bar of white separating it from the green on the breast.

There are diminutives of both these birds; they have the same habits, with a somewhat different plumage, and about half the size. Arrayed from head to tail in a robe of richest sable hue, the bird called Rice-bird loves spots cultivated by the hand of man. The woodcutter's house on the hills in the interior, and the planter's habitation on the sea-coast, equally attract this songless species of the order of pie, provided the Indian corn be ripe there. He is nearly of the jackdaw's size, and makes his nest far arvay from the haunts of man; he may truly be called a blackbird: independent of his plumage, his beak, inside and out, his legs, his toes, and claws are jet black.

Mankind, by clearing the ground, and sowing a variety of seeds, induces many kinds of birds to leave their native haunts and come and settle near him; their little depredations on his seeds and fruits prove that it is the property, and not the proprietor, which has the attractions.

One bird, however, in Demerara is not actuated by selfish motives: this is the Cassique; in size, he is larger than the starling; he courts the society of man, but disdains to live by his labours. When nature calls for support, he repairs to the neighbouring forest, and there partakes of the store of fruits and seeds which she has produced in abun- 


\section{WANDERINGS IN SOUTH AMERICA}

dance for her aërial tribes. When his repast is over, he returns to man, and pays the little tribute which he owes him for his protection; he takes his station on a tree close to his house; and there, for hours together, pours forth a succession of imitative notes. His own song is sweet, but very short. If a toucan be relping in the neighbourhood, he drops it, and imitates him. Then he will amuse his protector with the cries of the different species of the woodpecker; and when the sheep bleat, he will distinctly answer them. Then comes his own song again; and if a puppy-dog, or a Guinea-fowl interrupt him, he takes them off admirably, and by his different gestures during the time, you would conclude that he enjoys the sport.

The cassique is gregarious, and imitates any sound he hears with such exactness, that he goes by no other name than that of Mocking-bird amongst the colonists.

At breeding time, a number of these pretty choristers resort to a tree near the planter's house, and from its outside branches weare their pendulous nests. So conscions do they seem that they never give offence, and so little suspicious are they of receiving any injury from man, that they will choose a tree within forty yards of his house, and occupy the branches so low down, that he may peep into the nests. A tree in Waratilla creek affords a proof of this.

The proportions of the cassique are so fine, that he may be said to be a model of symmetry in ornithology. On each wing he has a bright yellow spot, and his rump, belly, and half the tail, are of the same colour. All the rest of the body is black. 


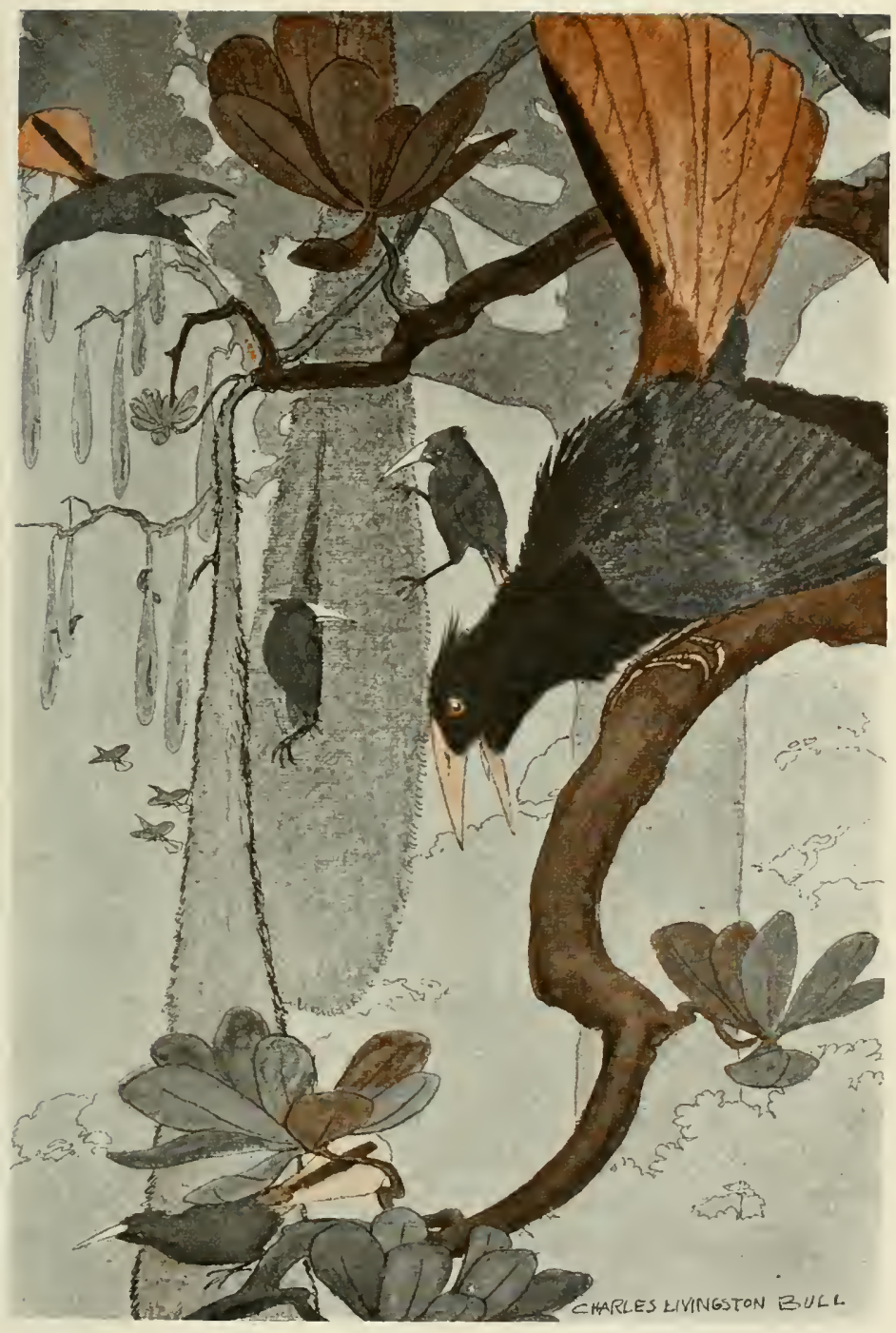

The Cassique 

His beak is the colour of sulphur, but it fades in death, and requires the same operation as the bill of the toucan to make it keep its colours. Up the rivers, in the interior, there is another cassique, nearly the same size, and of the same habits, though not gifted with its powers of imitation. Except in breeding time you will see hundreds of them retiring to roost, amongst the mocamoca-trees and low shrubs on the banks of the Demerara, after you pass the first island. They are not common on the sea-coast. The rump of this cassique is a flaming scarlet. All the rest of the body is a rich glossy black. His bill is sulphur colour. You may often see numbers of this species weaving their pendulous nests on one side of a tree, while numbers of the other species are busy in forming theirs on the other side of the same tree. Though such near neighbours, the females are never observed to kick up a row, or come to blows!

Another species of cassique, as large as a crow, is very common in the plantations. In the morning, he generally repairs to a large tree, and there, with his tail spread over his back, and shaking his lowered wings, he produces notes, which though they cannot be said to amount to a song, still have something very sweet and pleasing in them. He makes his nest in the same form as the other cassiques. It is above four feet long; and when you pass under the tree, which often contains fifty or sixty of them, you cannot help stopping to admire them as they wave to and fro, the sport of every storm and breeze. The rump is chestnut; ten feathers of the tail are a fine yellow, 


\section{WANDERINGS IN SOUTH AMERICA}

the remaining two, which are the middle ones, are black, and an inch shorter than the others. His bill is sulphur colour; all the rest of the body black, with here and there shades of brown. He has five or six long narrow black feathers on the back of his head, which he erects at pleasure.

There is one more species of cassique in Demerara, which always prefers the forests to the cultivated parts. His economy is the same as that of the other cassiques. He is rather smaller than the last described bird. His body is greenish, and his tail and rump paler than those of the former. Half of his beak is red.

You would not be long in the forests of Demerara without noticing the Woodpeckers. You meet with them feeding at all hours of the day. Well may they do so. Were they to follow the example of most of the other birds, and only feed in the morning and evening, they would be often on short allowance, for they sometimes have to labour three or four hours at the tree before they get to their food. The sound which the largest kind makes in hammering against the bark of the tree, is so lond, that you would never suppose it to proceed from the efforts of a bird. You would take it to be the woodman, with his axe, trying by a sturdy blow, often repeated, whether the tree were sound or not. There are fourteen species here; the largest the size of a magpie, the smallest no bigger than the wren. They are all beautiful; and the greater part of them have their heads ornamented with a fine crest, movable at pleasure.

It is said, if you once give a dog a bad name, whether innocent or guilty, he never loses it. It 
sticks close to him wherever he goes. He has many a kick and many a blow to bear on account of it; and there is nobody to stand up for him. The woodpecker is little better off. The proprietors of woods, in Europe, have long accused him of injuring their timber, by boring holes in it, and letting in the water, which soon rots it. The colonists in America have the same complaint against him. Had he the power of speech, which Ovid's birds possessed in days of yore, he could soon make a defence. "Mighty lord of the woods," he would say to man, "why do you wrongfully accuse me? why do you hunt me up and down to death for an imaginary offence? I have never spoiled a leaf of your property, much less your wood. Your merciless shot strikes me, at the very time I am doing you a service. But your shortsightedness will not let you see it, or your pride is above examining closely the actions of so insignificant a little bird as I am. If there be that spark of feeling in your breast which they say man possesses, or ought to possess, above all other animals, do a poor injured creature a little kindness, and watch me in your woods only for one day. I never wound your healthy trees. I would perish for want in the attempt. The sound bark would easily resist the force of my bill : and were I even to pierce through it, there would be nothing inside that I could fancy, or my stomach digest. I often visit them, it is true, but a knock or two convinces me that I must go elsewhere for support; and were you to listen attentively to the sound which my bill causes, you would know whether I am upon a healthy or an unhealthy tree. 


\section{WANDERINGS IN SOUTH AMERICA}

Wood and bark are not my food. I live entirely upon the insects which liave already formed a lodgment in the distempered tree. When the sound informs me that my prey is there, I labour for hour's together till I get at it; and by consuming it, for my own support, I prevent its further depredations in that part. Thus I discover for you your hidden and unsuspected foe, which has been devouring your wood in such secrecy, that you had not the least suspicion it was there. The hole which I make in order to get at the pernicious vermin will be seen by you as you pass under the tree. I leave it as a signal to tell you that your tree has already stood too long. It is past its prime. Millions of insects, engendered by disease, are preying upon its vitals. Ere long it will fall a $\log$ in useless ruins. Warned by this loss, cut down the rest in time, and spare, $\mathrm{O}$ spare the unoffending woodpecker!'”

In the rivers and different creeks, you number six species of the Kingfisher. They make their nest in a hole in the sand on the side of the bank As there is always plenty of foliage to protect them from the heat of the sun, they feed at all hours of the day. Though their plumage is prettily varied, still it falls far short of the brilliancy displayed by the English kingfisher. This little

- native of Britain would outweigh them altogether in the scale of beauty.

A bird called Jacamar is often taken for a kingfisher, but it has no relationship to that tribe; it frequently sits in the trees over the water, and as its beak bears some resemblance to that of the kingfisher, this may probably account for its being 
taken for one; it feeds entirely upon insects; it sits on a branch in motionless expectation, and as soon as a fly, butterfly, or moth passes by, it darts at it, and returns to the branch it had just left. It seems an indolent, sedentary bird, shunning the society of all others in the forest. It never visits the plantations, but is found at all times of the year in the woods. There are four species of jacamar in Demerara; they are all beautiful; the largest, rich and superb in the extreme. Its plumage is of so fine a changing blue and golden green, that it may be ranked with the choicest of the humming-birds. Nature has denied it a song, but given a costly garment in lieu of it The smallest species of jacamar is very common in the dry savannas. The second size, all golden green on the back, must be looked for in the wallaba forest. The third is found throughout the whole extent of these wilds; and the fourth, which is the largest, frequents the interior, where you begin to perceive stones in the ground.

When you have penetrated far into Macoushia, you hear the pretty songster called Troupiale pour forth a variety of sweet and plaintive notes. This is the bird which the Portuguese call the Nightingale of Guiana; its predominant colours are rich orange and shining black, arrayed to great advantage; his delicate and well-shaped frame seems unable to bear captivity. The Indians sometimes bring down troupiales to Stabroek, but in a few months they languish and die in a cage. They soon become very familiar; and if you allow them the liberty of the house, they live longer than in a cage, and appear in better 
spirits; but, when you least expect it, they drop down and die in epilepsy.

Smaller in size, and of colour not so rich and somewhat differently arranged, another species of troupiale sings melodionsly in Demerara. The woodcutter is particularly favoured by him; for while the hen is sitting on her nest, built in the roof of the woodcutter's house, he sings for hours together elose by: he prefers the forests to the cultivated parts.

You would not grudge to stop for a few minutes, as you are walking in the plantations, to observe a third species of troupiale: his wings, tail, and throat are black, all the rest of the body is a bright yellow. There is something very sweet and plaintive in his song, though much shorter than that of the troupiale in the interior.

A fourth species goes in flocks from place to place in the cultivated parts at the time the Indian corn is ripe; he is all black, except the head and throat, which are yellow; his attempt at song is not worth attending to.

Wherever there is a wild fig-tree ripe, a numerous species of birds, called Tangara, is sure to be on it. There are eighteen beautiful species here. Their plumage is very rich and diversified; some of them boast six separate colours; others have the blue, purple, green, and black so kindly blended into each other, that it would be impossible to mark their boundaries; while others again exhibit them strong, distinct, and abrupt: many of these tangaras have a fine song. They seem to partake much of the nature of our linnets, sparrows, and finches. Some of them are fond of the 
plantations; others are never seen there, preferring the wild seeds of the forest to the choicest fruits planted by the hand of man.

On the same fig-trees to which they repair, and often accidentally up and down the forest, you fall in with four species of Manikin. The largest is white and black, with the feathers on the throat remarkably long: the next in size is half red and half black: the third, black, with a white crown: the fourth, black, with a golden crown, and red feathers at the knee. The half red and half black species is the scarcest. There is a creek in the Demerara called Camouni. About ten minutes from the mouth, you see a common-sized fig-tree on your right hand, as you ascend, hanging over water; it bears a very small fig twice a year. When its fruit is ripe, this manikin is on the tree from morn till eve.

On all the ripe fig-trees in the forest you see the bird called the small Tiger-bird. Like some of our belles and dandies, it has a gaudy vest to veil an ill-shaped body: the throat, and part of the head, are a bright red; the breast and belly have black spots on a yellow ground; the wings are a dark green, black, and white; and the rump and tail black and green. Like the manikin, it has no song: it depends solely upon a showy garment for admiration.

Devoid, too, of song, and in a still superber garb, the Yawaraciri comes to feed on the same tree. It has a bar like black velvet from the eyes to the beak; its legs are yellow; its throat, wings and tail black; all the rest of the body a charming blue. Chiefly in the dry savannas, and here and 


\section{WANDERINGS IN SOUTH AMERICA}

there accidentally in the forest, you see a songless yawaraciri still lovelier than the last: his crown is whitish blue, arrayed like a coat of mail: his tail is black, his wings black and yellow; legs red; and the whole body a glossy blue. Whilst roving through the forest, ever and anon you see individnals of the wren species, busy amongst the fallen leaves, or seeking insects at the roots of the trees.

Here, too, you find six or seven species of small birds, whose backs appear to be overloaded with silky plumage. One of these, with a chestnut breast, smoke-coloured back, red tail, white feathers like horns on his head, and white, narrow-pointed feathers under the jaw, feeds entirely upon ants. When a nest of large, light brown ants emigrates, one following the other in meandering lines above a mile long, you see this bird watching them, and every now and then picking them up. When they disappear he is seen no more: perhaps this is the only kind of ant he is fond of; when these ants are stirring, you are sure to find him near them. You cannot well mistake the ant after you have once been in its company, for its sting is very severe, and you can hardly shoot the bird, and pick it up, without having five or six upon you.

Parrots and Paroquets are very numerous here, and of many different kinds. You will know when they are near you in the forest, not only by the noise they make, but also by the fruits and seeds which they let fall while they are feeding.

The Hia-hia Parrot, called in England the Parrot of the Sun, is very remarkable: he can erect at pleasure a fine radiated circle of tartan feathers 
quite round the back of his head from jaw to jaw. The fore-part of his head is white; his back, tail, and wings, green; and his breast and belly tartan.

Superior in size and beanty to every parrot of South America, the Ara will force you to take your eyes from the rest of animated nature, and gaze at him : his commanding strength, the flaming scarlet of his body, the lovely variety of red, yellow, blue and green in his wings, the extraordinary length of his scarlet and blue tail, seem all to join and demand for him the title of "emperor of all the parrots." He is scarce in Demerara till you reach the confines of the Macoushi country; there he is in vast abundance; he mostly feeds on trees of the palm species. When the coucouritetrees have ripe fruit on them, they are covered with this magnificent parrot: he is not shy or wary; you may take your blow-pipe and quiver of poisoned arrows, and kill more than you are able to carry back to your hut. They are very vociferous, and like the common parrots, rise up in bodies towards sunset, and fly two and two to their place of rest. It is a grand sight in ornithology to see thousands of aras flying over your head, low enough to let you have a full view of their flaming mantle. The Indians find their flesh very good, and the feathers serve for ornaments in their head-dresses. They breed in the holes of trees, are easily reared and tamed, and learn to speak pretty distinctly.

Another species frequents the low lands of Demerara. He is nearly the size of the scarlet ara, but much inferior in plumage. Blue and yellow are his predominant colours. 
Along the creeks and river sides, and in the wet savannas, six species of the Bittern will engage your attention. They are all handsome. The smallest not so large as the English water-hen.

In the savannas, too, you will sometimes surprise the snow-white Egrette, whose back is adorned with the plumes from which it takes its name. Here too the spur-winged Water-hen, the blue and green Water-hen, and two other species of ordinary plumage, are found. While in quest of these, the Blue Heron, the large and small Brown Heron, the Boat-bill, and Muscovy Duck, now and then rise up before you.

When the sun has sunk in the western woods, no longer agitated by the breeze; when you can only see a straggler or two of the feathered tribe hastening to join its mate, already at its roostingplace, then it is that the Goatsucker comes out of the forest, where it has sat all day long in slumbering ease, unmindful of the gay and busy scenes around it. Its eyes are too delicately formed to bear the light, and thus it is forced to shun the flaming face of day, and wait in patience till night invites him to partake of the pleasures her dusky presence brings.

The harmless, unoffending goatsucker, from the time of Aristotle down to the present day, has been in disgrace with man. Father has handed down to son, and author to author that this noeturnal thief subsists by milking the flocks. Poor injured little bird of night, how sadly hast thou suffered, and how foul a stain has inattention to facts put upon thy character! Thou hast never 
robbed man of any part of his property, nor deprived the kid of a drop of milk.

When the moon shines bright, you may have a fair opportunity of examining the goatsucker. You will see it close by the cows, goats, and sheep, jumping up every now and then, under their bellies. Approach a little nearer,--he is not shy, "lie fears no danger, for he knows no sin." See how the nocturnal flies are tormenting the herd, and with what dexterity he springs up and catches them, as fast as they alight on the belly, legs, and udder of the animals. Observe how quiet they stand, and how sensible they seem of his good offices, for they neither strike at him, nor hit him with their tail, nor tread on him, nor try to drive him away as an uncivil intruder. Were you to dissect him, and inspect his stomach, you would find no milk there. It is full of the flies which have been annoying the herd.

The prettily mottled plumage of the goatsucker, like that of the owl, wants the lustre which is observed in the feathers of the birds of day. This at once marks him as a lover of the pale moon's nightly beams. There are nine species here. The largest appears nearly the size of the English wood-owl. Its cry is so remarkable, that having once heard it you will never forget it. When night reigns over these immeasurable wilds, whilst lying in your hammock, you will hear this goatsucker lamenting like one in deep distress. A stranger would never conceive it to be the cry of a bird. He would say it was the departing voice of a midnight-murdered victim, or the last wailing of $\mathrm{Ni}$ obe for her poor children, before she was turned 


\section{WANDERINGS IN SOUTH AMERICA}

into stone. Suppose yourself in hopeless sorrow, begin with a high loud note, and pronounce, "ha, ha, ha, ha, ha, ha, ha," each note lower and lower, till the last is scarcely heard, pausing a moment or two betwixt every note, and you will have some idea of the moaning of the largest goatsucker in Demerara.

Four other species of the goatsucker articulate some words so distinctly, that they have received their names from the sentences they utter, and absolutely bewilder the stranger on his arrival in these parts. The most common one sits down close by your door, and flies and alights three or four yards before you, as you walk along the road, crying, "Who-are-you, who-who-who-are-you?" Another bids you, "Work-away, work-work-workaway." A third cries, mournfully, "Willy-comego. Willy-Willy-Willy-come-go."' And high up in the country, a fourth tells you to "Whip-poorWill. Whip-whip-whip-poor-Will.",

You will never persuade the negro to destroy these birds or get the Indian to let fly his arrow at them. They are birds of omen and reverential dread. Jumbo, the demon of Africa, has them under his command; and they equally obey the Yabahou, or Demerara Indian Devil. They are the receptacles for departed souls, who come back again to earth, unable to rest for crimes done in their days of nature; or they are expressly sent by Jumbo, or Yabahou, to haunt cruel and hardhearted masters, and retaliate injuries received from them. If the largest goatsucker chance to cry near the white man's door, sorrow and grief will soon be inside; and they expect to see 
the master waste away with a slow-consuming sickness. If it be heard close to the negro's or Indian's hut, from that night misfortune sits brooding over it; and they await the event in terrible suspense.

You will forgive the poor Indian of Guiana for this. He knows no better ; he has nobody to teach him. But shame it is, that in our own civilized country, the black cat and broomstaff should be considered as conductors to and from the regions of departed spirits.

Many years ago I knew poor harmless Mary; old age had marked her strongly, just as he will mark you and me, should we arrive at her years and carry the weight of grief which bent her double. The old men of the village said she had been very pretty in her youth; and nothing could be seen more comely than Mary when she danced on the green. He who had gained her heart, left her for another, less fair, though richer than Mary. From that time she became sad and pensive; the rose left her cheek, and she was never more seen to dance round the May-pole on the green: her expectations were blighted; she became quite indifferent to everything around her, and seemed to think of nothing but how she conld best attend her mother, who was lame, and not long for this life. Her mother had begged a black kitten from some boys who were going to drown it, and in her last illness she told Mary to be kind to it for her sake.

When age and want had destroyed the symmetry of Mary's fine form, the village began to consider her as one who had dealings with spirits; 
her cat confirmed the suspicion. If a cow died, or a villager wasted away with an unknown complaint, Mary and her cat had it to answer for. Her broom sometimes served her for a walkingstick; and if ever she supported her tottering frame with it as far as the May-pole, where once, in youthful bloom and beauty, she had attracted the eyes of all, the boys would surround her, and make sport of her, while her cat had neither friend nor safety beyond the cottage wall. Nobody considered it cruel or uncharitable to torment a witch; and it is probable, long before this, that cruelty, old age, and want, have worn her out, and that both poor Nary and her cat have ceased to be.

Would you wish to pursue the different species of game, well stored and boundless is your range in Demerara. Here no one dogs you, and afterwards clandestinely inquires if you have a hundred a year in land to entitle you to enjoy such patrician sport. Here no saucy intruder asks if you have taken out a licence, by virtue of which you are allowed to kill birds which have bred upon your own property. Here

"You are as free as when God first made man,

Ere the vile laws of servitude began,

And wild in woods the noble savage ran."

Before the morning's dawn you hear a noise in the forest, which sounds like "duraquaura" often repeated. This is the Partridge, a little smaller, and differing somewhat in colour from the English partridge; it lives entirely in the forest, and probably the young brood very soon leave their parents, as you never flush more than two birds in the same place, and in general only one. 


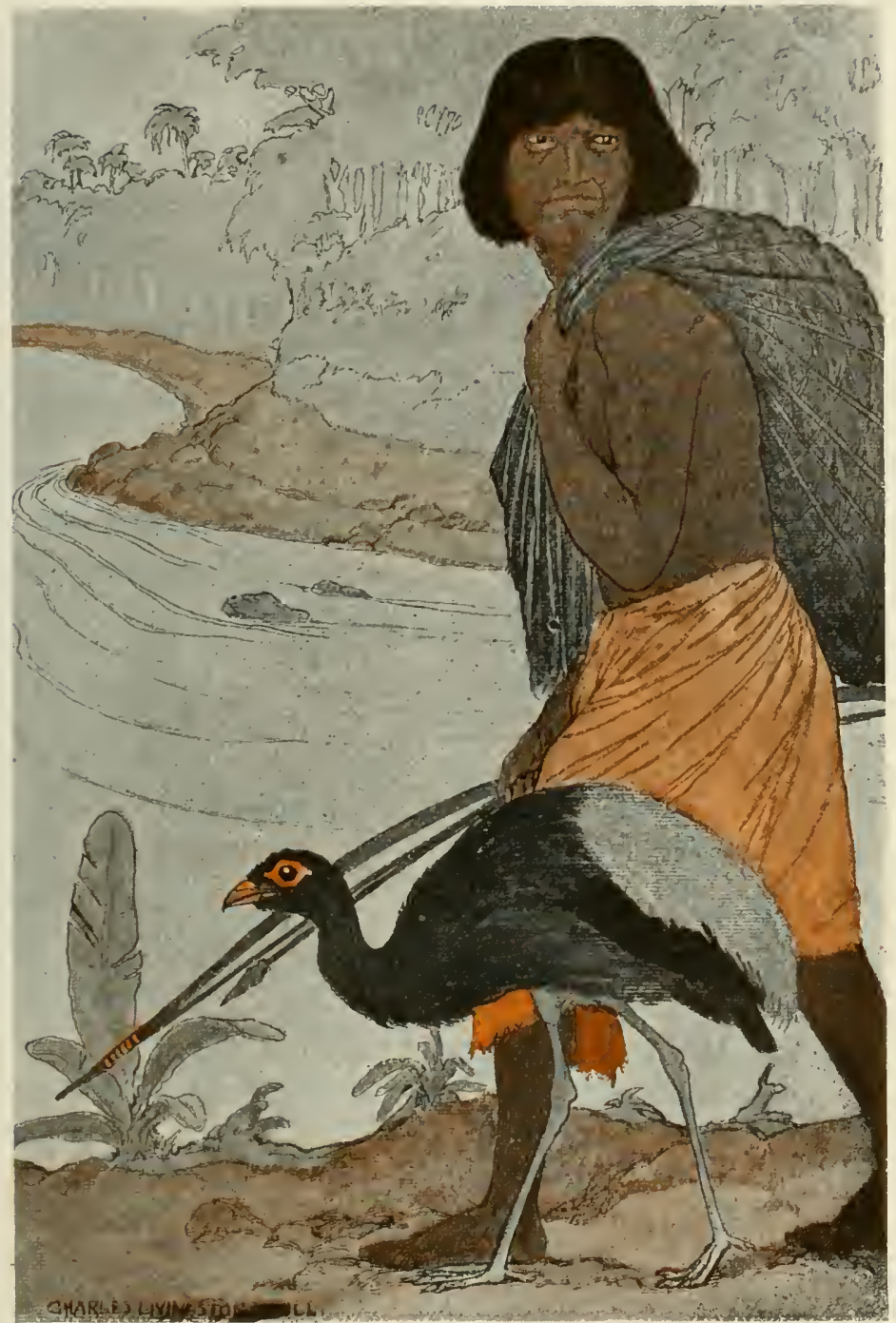

Trumpeter walking with his Master 

About the same hour, and sometimes even at midnight, you hear two species of Maam, or Tinamou, send forth their long and plaintive whistle from the depth of the forest. The flesh of both is delicious. The largest is plumper, and almost equals in size the black cock of Northumberland. The quail is said to be here, though rare.

The Hannaquoi, which some have compared to the pheasant, though with little reason, is very common.

Here are also two species of the Powise, or Hocco, and two of the small wild turkeys called Maroudi; they feed on the ripe fruits of the forest, and are found in all directions in these extensive wilds. You will admire the Horned Screamer as a stately and majestic bird: he is almost the size of the turkey cock; on his head is a long slender horn, and each wing is armed with a strong, sharp, triangular spur, an inch long.

Sometimes you will fall in with flocks of two or three hundred Waracabas, or Trumpeters, called so from the singular noise they produce. Their breast is adorned with beautiful changing blue and purple feathers; their head and neck like velvet; their wings and back grey, and belly black. They run with great swiftness, and when domesticated, attend their master in his walks with as much apparent affection as his dog. They have no spurs, but still, such is their high spirit and activity, that they browbeat every dunghill fowl in the yard, and force the Guinea birds, dogs and turkeys to own their superiority.

If, kind and gentle reader, thou shouldst ever visit these regions with an intention to examine 
their productions, perhaps the few observations contained in these Wanderings may be of service to thee; excuse their brevity: more conld have been written, and each bird more particularly described, but it would have been pressing too hard upon thy time and patience.

Soon after arriving in these parts, thou wilt find that the species here enumerated are only as a handful from a well-stored granary. Nothing has been said of the Eagles, the Falcons, the Hawks, and Shrikes; nothing of the different species of Vultures, the king of which is very handsome, and seems to be the only bird which claims regal honours from a surrounding tribe. It is a fact beyond all dispute, that when the scent of carrion has drawn together humdreds of the common vultures, they all retire from the carcass as soon as the King of the Vultures makes his appearance. When his majesty has satisfied the cravings of his royal stomach with the choicest bits from the most stinking and corrupted parts, he generally retires to a neighbouring tree, and then the common vultures return in crowds to gobble down his leavings. The Indians, as well as the whites, have observed this; for when one of them, who has learned a little English, sees the king, and wishes you to have a proper notion of the bird, he says, "There is the governor of the carrion crows."

Now, the Indians have never heard of a personage in Demerara higher than that of governor; and the colonists, through a common mistake, call the vultures carrion crows. Hence, the Indian, in order to express the dominion of this bird over the common vultures, tells you he is governor 
of the carrion crows. The Spaniards have also observed it; for, through all the Spanish Main, he is called Rey de Zamuros, King of the Vultures. The many species of Owls, too, have not been noticed; and no mention made of the Columbine tribe. The prodigious variety of Water Fowl on the sea-shore has been but barely hinted at.

There, and on the borders and surface of the inland waters, in the marshes and creeks, besides the flamingos, scarlet curlews, and spoonbills, already mentioned, will be found Greenish-Brown Curlews, Sandpipers, Rails, Coots, Gulls, Pelicans, Jabirus, Nandapoas, Crabiers, Snipes, Plovers, Ducks, Geese, Cranes, and Anhingas; most of them in vast abundance; some frequenting only the sea-coast, others only the interior, according to their different natures; all worthy the attention of the naturalist, all worthy of a place in the cabinet of the curious.

Should thy comprehensive genius not confine itself to birds alone, grand is the appearance of other objects all around. Thou art in a land rich in botany and mineralogy, rich in zoölogy and entomology. Animation will glow in thy looks, and exercise will brace thy frame in vigour. The very time of thy absence from the tables of heterogeneous luxury will be profitable to thy stomach, perhaps already sorely drenched with LondoParisian sauces, and a new stock of health will bring thee an appetite to relish the wholesome food of the chase; never-failing sleep will wait on thee at the time she comes to soothe the rest of animated nature; and, ere the sun's rays appear in the horizon, thou wilt spring from thy ham- 


\section{WANDERINGS IN SOUTH AMERICA}

mock fresh as the April lark. Be convinced also, that the dangers and difficulties which are generally supposed to accompany the traveller in his journey through distant regions, are not half so numerous or dreadful as they are commonly thought to be.

The youth who incautiously reels into the lobby of Drury-lane, after leaving the table sacred to the god of wine, is exposed to more certain ruin, sickness and decay, than he who wanders a whole year in the wilds of Demerara. But this will never be believed; because the disasters arising from dissipation are so common and frequent in civilized life, that man becomes quite habituated to them; and sees daily victims sink into the tomb long before their time, without ever once taking alarm at the causes which precipitated them headlong into it.

But the dangers which a traveller exposes himself to in foreign parts are novel, ont of the way things to a man at home. The remotest apprehension of meeting a tremendous tiger, of being carried off by a flying dragon, or having his bones picked by a famished cannibal; oh, that makes him shudder. It sounds in his ears like the bursting of a bomb-shell. Thank Heaven, he is safe by his own fire-side!

Prudence and resolution ought to be the traveller's constant companions. The first will cause him to avoid a number of snares which he will find in the path as he journeys on; and the second will always lend a hand to assist him, if he has unavoidably got entangled in them. The little distinctions which have been shown him at 
his own home ought to be forgotten when he travels over the world at large; for strangers know nothing of his former merits, and it is necessary that they should witness them before they pay him the tribute which he was wont to receive within his own doors. Thus, to be kind and affable to those we meet, to mix in their amusements, to pay a compliment or two to their manners and customs, to respect their elders, to give a little to their distressed or needy, and to feel, as it were, at home amongst them, is the sure way to enable you to pass merrily on, and to find other comforts as sweet and palatable as those which you were accustomed to partake of amongst your friends and acquaintance in your own native land.

We will now ascend in fancy on Icarian wing, and take a view of Guiana in general. See an immense plain! betwixt two of the largest rivers in the world, level as a bowling-green, save at Cayenne, and covered with trees along the coast quite to the Atlantic wave, except where the plantations make a little vacancy amongst the foliage.

Though nearly in the centre of the torrid zone, the sun's rays are not so intolerable as might be imagined, on account of the perpetual verdure and refreshing north-east breeze. See what numbers of broad and rapid rivers intersect it in their journey to the ocean, and that not a stone or a pebble is to be found on their banks, or in any part of the country, till your eye catches the hills in the interior. How beantiful and magnificent are the lakes in the heart of the forests, and how charming the forests themselves, for miles after miles on each side of the river's! How extensive 


\section{WANDERINGS IN SOUTH AMERICA}

appear the savannas or natural meadows, teeming: with innumerable herds of cattle, where the Portuguese and Spaniards are settled, but desert as Saara, where the English and Dutch claim dominion! How gradually the face of the country rises! See the sand-hills all clothed in wood first emerging from the level, then hills a little higher, rug'ed with bold and craggy rocks, peeping out from amongst the most luxuriant timber. Then come plains, and dells, and far-extending valleys, arrayed in richest foliage; and beyond them, mountains piled on mountains, some bearing prodigious forests, others of bleak and barren aspect. Thus your eye wanders on, over scenes of varied loveliness and grandeur, till it rests on the stupendous pinnacles of the long-continued Cordilleras de los Andes, which rise in towering majesty and command all America.

How fertile must the low-lands be, from the accumulation of fallen leaves and trees for centuries! How propitious the swamps and slimy beds of the rivers, heated by a downward sun, to the amazing growth of alligators, serpents, and innumerable insects! How inviting the forests to the feathered tribes, where you see buds, blossoms, green and ripe fruit, full grown and fading leaves, all on the same tree! How secure the wild beasts may rove in endless mazes! Perhaps those mountains too, which appear so bleak and naked, as if quite neglected, are, like Potosi, full of precious metals.

Let us now return the pinions we borrowed from Icarus, and prepare to bid farewell to the wilds. The time allotted to these Wanderings is 
drawing fast to a close. Every day for the last six months has been employed in paying close attention to natural history in the forests of Demerara. Above two hundred specimens of the finest birds have been collected, and a pretty just knowledge formed of their haunts and economy. From the time of leaving England, in March, 1816, to the present day, nothing has intervened to arrest a fine flow of health, saving a quartan ague, which did not tarry, but fled as suddenly as it appeared. And now I take leave of thee, kind and gentle reader. The new mode of preserving birds, heretofore promised thee, shall not be forgotten. The plan is already formed in imagination, and can be penned down during the passage across the Atlantic. If the few remarks in these Wanderings shall have any weight in inciting thee to sally forth and explore the vast and well-stored regions of Demerara, I have gained my end. Adieu.

\section{Charles Waterton.}

April 6, $181 \%$. 


\section{THIRD JOURNEY}

\section{CHAPTER I \\ "Desertosque videre locos, littusque relictum."}

Gentle reader, after staying a few months in England, I strayed across the Alps and the Appenines, and returned home, but conld not tarry. Guiana still whispered in my ear, and seemed to invite me once more to wander through her distant forests.

Shouldst thou have a leisure hour to read what follows, I pray thee pardon the frequent use of that unwelcome monosyllable $I$. It could not well be avoided, as will be seen in the sequel. In February, 1820, I sailed from the Clyde on board the Glenbervie, a fine West-Indiaman. She was driven to the north-west of Ireland, and had to contend with a foul and wintry wind for above a fortnight. At last it changed, and we had a pleasant passage across the Atlantic.

Sad and mournful was the story we heard on entering the river Demerara. The yellow fever had swept off numbers of the old inhabitants, and the mortal remains of many a new comer were daily passing down the streets, in slow and mute procession to their last resting-place.

After staying a few days in the town, I went up the Demerara to the former habitation of my worthy friend, Mr. Edmonstone, in Mibiri creek. 
The house had been abandoned for some years. On arriving at the hill, the remembrance of scenes long past and gone naturally broke in upon the mind. All was changed; the house was in ruins, and gradually sinking under the influence of the sun and rain; the roof had nearly fallen in; and the room where once governors and generals had caroused, was now dismantled, and tenanted by the vampire. You would liave said,

\footnotetext{
"' 'Tis now the vampire's bleak abode, 'Tis now the apartment of the toad;

'Tis here the painful Chegoe feeds,

'Tis here the dire Labarri breeds,

Conceal'd in ruins, moss, and weeds.",
}

On the outside of the house, nature had nearly reassumed her ancient right: a few straggling fruit-trees were still discernible amid the varied hue of the near approaching forest; they seemed like strangers lost, and bewildered, and unpitied, in a foreign land, destined to linger a little longer, and then sink down for ever.

I hired some negroes from a woodcutter in another creek to repair the roof; and then the house, or at least what remained of it, became head-quarters for natural history. The frogs, and here and there a snake, received that attention which the weak in this world generally experience from the strong, and which the law commonly denominates an ejectment. But here, neither the frogs nor serpents were ill-treated; they sallied forth, without buffet or rebuke, to choose their place of residence; the world was all before them. The owls went away of their own accord, prefer- 
ing to retire to a hollow tree rather than to associate with their new landlord. The bats and vampires stayed with me, and went in and out as usual.

It was upon this hill in former days that I first tried to teach John, the black slave of my friend Mr. Edmonstone, the proper way to do birds. But Joln had poor abilities, and it required much time and patience to drive anything into him. Some years after this his master took him to Scotland, where, becoming free, Joln left him, and got employed in the Glasgow, and then the Edinburgh museum. Mr. Robert Edmonstone, nephew to the above gentleman, liad a fine mulatto capable of learning anything. He requested me to teach him the art. I did so. He was docile and active, and was with me all the time in the forest; I left lim there to keep up this new art of preserving birds, and to commmicate it to others. Here then I fixed my head quarters, in the ruins of this once gay and hospitable house. Close by, in a little hut, which in times long past had served for a store to keep provisions in, there lived a coloured man and his wife, by name Backer. Many a kind turn they did to me; and I was more than once of service to then and their children, by bringing to their relief in time of sickness what little knowledge I had acquired of medicine.

I would here, gentle reader, wish to draw thy attention, for a few minutes, to physic, raiment, and diet. Shouldst thou ever wander through these remote and dreary wilds, forget not to carry with thee bark, laudanum, calomel, and jalap, and the lancet. There are no druggist shops here, 
nor sons of Galen to apply to in time of need. I never go encumbered with many clothes. A thin flannel waistcoat under a check shirt, a pair of trousers, and a hat, were all my wardrobe; shoes and stockings I seldom had on. In dry weather they would have irritated the feet, and retarded me in the cliase of wild beasts; and in the rainy season they would have kept me in a perpetual state of damp and moisture. I eat moderately, and never drink wine, spirits, or fermented liquors in any climate. This abstemiousness has ever proved a faithful friend; it carried me triumphant through the epidemia at Malaga, where death made such havoc about the beginning of the present century; and it has since befriended me in many a fit of sickness, brought on by exposure to the noon-day sun, to the dews of night, to the pelting shower and unwholesome food.

Perhaps it will be as well, here, to mention a fever which came on, and the treatment of it; it may possibly be of use to thee, shouldst thou turn wanderer in the tropics: a word or two also of a wound I got in the forest, and then we will say no more of the little accidents which sometimes occur, and attend solely to natural history. We shall have an opportunity of seeing the wild animals in their native haunts, undisturbed and unbroken in upon by man. We shall have time and leisure to look more closely at them, and probably rectify some errors which, for want of proper information or a near observance, have crept into their several histories.

It was in the month of June, when the sun was 


\section{WANDERINGS IN SOUTH AMERICA}

within a few days of Cancer, that I had a severe attack of fever. There had been a deluge of rain, accompanied with tremendois thunder and lightning, and very little sun. Nothing could exceed the dampness of the atmosphere. For two or three days $I$ had been in a kind of twilight state of health, neither ill nor what you may call well; I yawned and felt weary without exercise, and my sleep was merely slumber. This was the time to have taken medicine; but I neglected to do so, though I had just been reading, "O navis referent in mare te novi fluctus, $O$ quid agis? fortiter occupa portum." I awoke at midnight; a cruel headache, thirst, and pain in the small of the back, informed me what the case was. Had Chiron himself been present, he could not have told me more distinctly that I was going to have a tight brush of it, and that I ought to meet it with becoming fortitude. I dozed, and woke, and startled, and then dozed again, and suddenly awoke, thinking I was falling down a precipice.

The return of the bats to their diurnal retreat, which was in the thatch above my hammock, informed me that the sun was now fast approaching to the eastern horizon. I arose, in langnor and in pain, the pulse at one hundred and twenty. I took ten grains of calomel and a scruple of jalap, and drank during the day large draughts of tea, weak and warm. The physic did its duty; but there was no remission of fever or headache, though the pain of the back was less acute. I was saved the trouble of keeping the room cool, as the wind beat in at every quarter.

At five in the evening the pulse had risen to one 
hundred and thirty, and the headache almost insupportable, especially on looking to the right or left. I now opened a vein, and made a large orifice, to allow the blood to rush out rapidly; I closed it after losing sixteen ounces. I then steeped my feet in warm water, and got into the hammock. After bleeding, the pulse fell to ninety, and the head was much relieved; but during the night, which was very restless, the pulse rose again to one hundred and twenty, and at times the headache was distressing. I relieved the headache from time to time by applying cold water to the temples, and holding a wet handkerchief there. The next morning the fever ran very high, and I took five more grains of calomel and ten of jalap, determined, whatever might be the case, this should be the last dose of calomel. About two o'clock in the afternoon the fever remitted, and a copious perspiration came on; there was no more headache, nor thirst, nor pain in the back, and the following night was comparatively a good one. The next morning I swallowed a large dose of castor oil : it was genuine, for Louisa Backer had made it from the seeds of the trees which grew near the door. I was now entirely free from all symptoms of fever, or apprehensions of a return; and the morning after I began to take bark, and continued it for a fortnight. This put all to rights.

The story of the wound I got in the forest, and the mode of cure, are very short.-I had pursued a red-headed woodpecker for above a mile in the forest, without being able to get a shot at it. Thinking more of the woodpecker, as I ran along, 


\section{WANDERINGS IN SOU'TH AMERICA}

than of the way before me, I trod upon a little hardwood stump, which was just about an inch or so above the ground; it entered the hollow part of my foot, making a deep and lacerated wound there. It had brought me to the ground, and there I lay till a transitory fit of sickness went off. I allowed it to bleed freely, and on reaching head-quarters, washed it well and probed it, to feel if any foreign body was left within it. Being satisfied that there was none, I brought the edges of the wound together, and then put a piece of lint on it, and over that a very large poultice, which was changed morning, noon, and night. Luckily, Backer had a cow or two upon the hill: now as heat and moisture are the two principal virtues of a poultice, nothing could produce those two qualities better than fresh cow-dung boiled: had there been no cows there, I could have made it with boiled grass and leaves. I now took entirely to the hammock, placing the foot higher than the knee; this prevented it from throbbing, and was, indeed, the only position in which I could be at ease. When the inflammation was completely subdued, I applied a wet cloth to the wound, and every now and then steeped the foot in cold water during the day, and at night again applied a poultice. The wound was now healing fast, and in three weeks from the time of the accident, nothing but a scar remained; so that I again sallied forth sound and joyful, and said to myself-

"I, pedes, quo te rapiunt et auræ

Dum favet sol, et locus, i secundo

Omine, et conto latebras, ut olim,

Rumpe ferarum." 
Now, this contus was a tough, light pole, eight feet long, on the end of which was fixed an old bayonet. I never went into the canoe without it; it was of great use in starting the beasts and snakes out of the hollow trees, and, in case of need, was an excellent defence.

In 1819, I had the last conversation with Sir Joseph Banks. I saw with sorrow that death was going to rob us of him. We talked much of the present mode adopted by all museums in stuffing quadrupeds, and condemned it as being very imperfect: still we could not find out a better way; and at last concluded, that the lips and nose ought to be eut off, and replaced with wax; it being impossible to make those parts appear like life, as they shrink to nothing, and render the stuffed specimens in the different museums horrible to look at. The defects in the legs and feet would not be quite so glaring, being eovered with hair.

I had paid great attention to this subject for above fourteen year's; still it would not do; however, one night while I was lying in the hammock, and harping on the string on which hung all my solicitude, I hit upon the proper mode by inference; it appeared clear to me that it was the only true way of going to work, and ere I closed my eyes in sleep, I was able to prove to myself that there could not be any other way that would answer. I tried it the next day, and succeeded according to expectation.

By means of this process, which is very simple, we can now give every feature back again to the animal's face, after it has been skinned; and when necessary, stamp grief, or pain, or pleasure, 
or rage, or mildness upon it. But more of this hereafter.

Let us now turn our attention to the Sloth, whose native haunts have litherto been so little known, and probably little looked into. Those who have written on this singular animal, have remarked that he is in a perpetual state of pain, that he is proverbially slow in his movements, that he is a prisoner in space, and that as soon as he has consumed all the leaves of the tree upon which he had mounted, he rolls himself up in the form of a ball, and then falls to the ground. This is not the case.

If the naturalists who have written the history of the sloth had gone into the wilds, in order to examine his haunts and economy, they would not have drawn the foregoing conclusions; they would have learned, that though all other quadrupeds may be described while resting upon the ground, the sloth is an exception to this rule, and that his history must be written while he is in the tree.

This singular animal is destined by nature to be produced, to live and to die in the trees; and to do justice to him, naturalists must examine him in this his upper element. $\mathrm{He}$ is a scarce and solitary animal, and being good food, he is never allowed to escape. He inhabits remote and gloomy forests, where snakes take up their abode, and where cruelly stinging ants and scorpions, and swamps, and innumerable thorny shrubs and bushes, obstruct the steps of civilized man. Were you to draw your own conclusions from the descriptions which have been given of the sloth, you would probably suspect, that no naturalist 


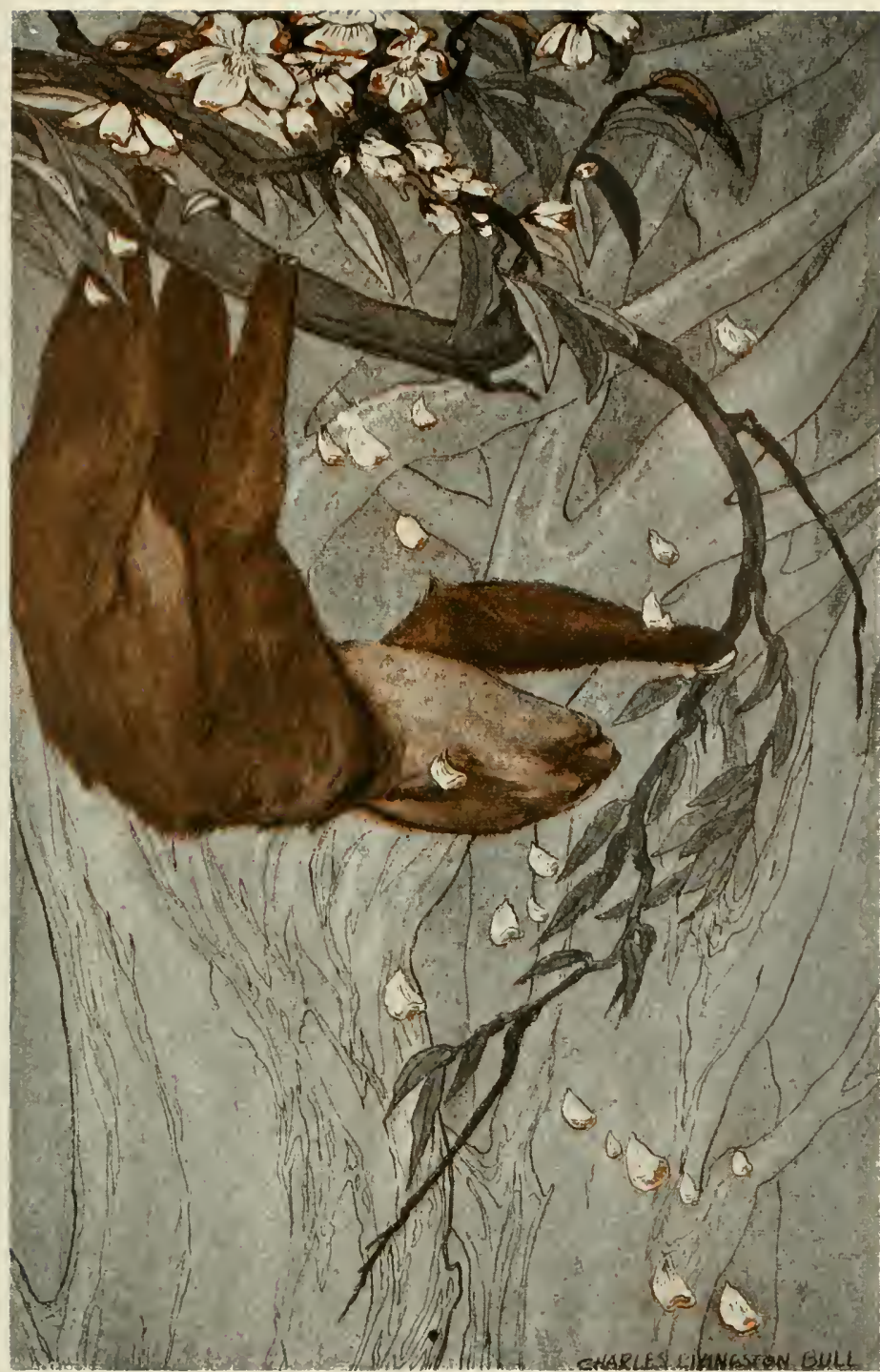

The Sloth 

has actually gone into the wilds with the fixed determination to find him out and examine his haunts and see whether nature has committed any blunder in the formation of this extraordinary creature, which appears to us so forlorn and miserable, so ill put together, and so totally unfit to enjoy the blessings which have been so bountifully given to the rest of animated nature; for, as it has formerly been remarked, he has no soles to his feet, and he is evidently ill at ease when he tries to move on the ground, and it is then that he looks up in your face with a countenance that says, "Have pity on me, for I am in pain and sorrow."

It mostly happens that Indians and Negroes are the people who catch the sloth, and bring it to the white man: hence it may be conjectured that the erroneous accounts we have hitherto had of the sloth, have not been penned down with the slightest intention to mislead the reader, or give him an exaggerated history, but that these errors have naturally arisen by examining the sloth in those places where nature never intended that he should be exhibited.

However, we are now in his own domain. Man but little frequents these thick and noble forests, which extend far and wide on every side of us. This, then, is the proper place to go in quest of the sloth. We will first take a near view of him. By obtaining a knowledge of his anatomy, we shall be enabled to account for his movements hereafter, when we see him in his proper haunts. His fore-legs, or, more correctly speaking, his arms, are apparently much too long, while his 


\section{WANDERINGS IN SOU'TH AMERICA}

hind-legs are very short, and look as if they could be bent almost to the shape of a corkscrew. Both the fore and hind legs, by their form, and by the manner in which they are joined to the body, are quite incapacitated from acting in a perpendicular direction, or in supporting it on the earth, as the bodies of other quadrupeds are supported, by their legs. Hence, when you place him on the floor, his belly tonches the ground. Now, granted that he supported himself on his legs like other animals, nevertheless he would be in pain, for he has no soles to his feet, and his claws are very sharp and long, and curved; so that, were his body supported by his feet it would be by their extremities, just as your body would be, were you to throw yourself on all fours, and try to support it on the ends of your toes and fingers-a trying position. Were the floor of glass, or of a polished surface, the sloth would actually be quite stationary; but as the ground is generally rough, with little protuberances upon it, such as stones, or roots of grass, \&c., this just suits the sloth, and he moves his fore-legs in all directions, in order to find something to lay hold of ; and when he has succeeded, he pulls himself forward, and is thus enabled to travel onwards, but at the same time in so tardy and awkward a manner, as to acquire him the name of Sloth.

Indeed his looks and his gestures evidently betray his uncomfortable situation; and as a sigh every now and then escapes him, we may be entitled to conclude that he is actually in pain.

Some years ago I kept a sloth in my room for several months. I often took him out of the house 
and placed him upon the ground, in order to have an opportunity of observing his motions. If the ground were rough, he would pull himself forwards, by means of his fore-legs, at a pretty good pace; and he invariably immediately shaped his course towards the nearest tree. But if I put him upon a smooth and well-trodden part of the road, he appeared to be in trouble and distress: his favourite abode was the back of a chair: and after getting all his legs in a line upon the topmost part of it, he would hang there for hours together, and often with a low and inward cry, would seem to invite me to take notice of him.

The sloth, in its wild state, spends its whole life in trees, and never leaves them but through force or by accident. An all-ruling Providence has ordered man to tread on the surface of the earth, the eagle to soar in the expanse of the skies, and the monkey and squirrel to inhabit the trees: still these may change their relative situations without feeling much inconvenience: but the sloth is doomed to spend his whole life in the trees; and, what is more extraordinary, not upon the branches, like the squirrel and the monkey, but under them. He moves suspended from the branch, he rests suspended from it, and he sleeps suspended from it. To enable him to do this, he must liave a very different formation from that of any other known quadruped.

Hence his seemingly bungled conformation is at once accounted for; and in lieu of the sloth leading a painful life and entailing a melancholy and miserable existence on its progeny, it is but fair to surmise that it just enjoys life as much 


\section{WANDERINGS IN SOU'TH AMERICA}

as any other animal, and that its extraordinary formation and singular habits are but further proofs to engage us to admire the wonderful works of Omnipotence.

It must be observed, that the sloth does not hang head-downwards like the vampire. When asleep, he supports himself from a branch parallel to the earth. He first seizes the branch with one arm, and then with the other; and after that, brings up both his legs, one by one, to the same branch; so that all four are in a line: he seems perfectly at rest in this position. Now, had he a tail, he would be at a loss to know what to do with it in this position: were he to draw it up within his legs, it would interfere with them; and were he to let it hang down, it would become the sport of the winds. Thus his deficiency of tail is a benefit to him; it is merely an apology for a tail, scarcely exceeding an inch and a half in length.

I observed, when he was climbing, he never used his arms both together, but first one and then the other, and so on alternately. There is a singularity in his hair, different from that of all other animals, and, I believe, hitherto unnoticed by naturalists; his hair is thick and coarse at the extremity, and gradually tapers to the root, where it becomes fine as a spider's web. His fur has so much the hue of the moss which grows on the branches of the trees, that it is very difficult to make him out when he is at rest.

The male of the three-toed sloth has a longitudinal bar of very fine black hair on his back, rather lower than the shoulder-blades; on each side of this black bar there is a space of yellow 
hair, equally fine; it has the appearance of being pressed into the body, and looks exactly as if it had been singed. If we examine the anatomy of his fore-legs, we shall immediately perceive by their firm and muscular texture, how very capable they are of supporting the pendent weight of his body, both in climbing and at rest; and, instead of pronouncing them a bungled composition, as a celebrated naturalist has done, we shall consider them as remarkably well calculated to perform their extraordinary functions.

As the sloth is an inhabitant of forests within the tropics, where the trees touch each other in the greatest profusion, there seems to be no reason why he should confine himself to one tree alone for food, and entirely strip it of its leaves. During the many years I have ranged the forests, I have never seen a tree in such a state of nudity; indeed, I would hazard a conjecture, that, by the time the animal had finished the last of the old leaves, there would be a new crop on the part of the tree he had stripped first, ready for him to begin again, so quick is the process of vegetation in these countries.

There is a saying amongst the Indians, that when the wind blows, the sloth begins to travel. In calm weather he remains tranquil, probably not liking to cling to the brittle extremity of the branches, lest they should break with him in passing from one tree to another; but as soon as the wind rises, the branches of the neighbouring trees become interwoven, and then the sloth seizes hold of them, and pursues his journey in safety. There is seldom an entire day of calm in these 


\section{WANDERINGS IN SOUTH AMERICA}

forests. The trade-wind generally sets in about ten o'clock in the morning, and thus the sloth may set off after breakfast, and get a considerable way before dinner. He travels at a good round pace; and were you to see him pass from tree to tree, as I have done, you would never think of calling him a sloth.

Thus, it would appear that the different histories we have of this quadruped are erroneous on two accounts: first, that the writers of them, deterred by difficulties and local annoyances, have not paid sufficient attention to him in his native haunts; and secondly, they have described hum in a situation in which he was never intended by nature to cut a figure; I mean on the ground. The sloth is as much at a loss to proceed on his journey upon a smooth and level floor, as a man would be who had to walk a mile in stilts upon a line of feather beds.

One day, as we were crossing the Essequibo, I saw a large two-toed sloth on the ground upon the bank; how he had got there nobody could tell: the Indian said he had never surprised a sloth in such a situation before: he would hardly have come there to drink, for both above and below the place, the branches of the trees touched the water, and afforded him an easy and safe access to it. Be this as it may, though the trees were not above twenty yards from him, he could not make his way through the sand in time enough to escape before we landed. As soon as we got up to him he threw himself upon his back, and defended himself in gallant style with his fore-legs. "Come, poor" fellow," said I to him, "if thou hast got into a 
hobble to-day, thou shalt not suffer for it: I'll take no advantage of thee in misfortune; the forest is large enough both for thee and me to rove in: go thy ways up above, and enjoy thyself in these endless wilds; it is more than probable thou wilt never have another interview with man. So fare thee well." On saying this, I took a long stick which was lying there, held it for him to hook on, and then conveyed him to a high and stately mora. $\mathrm{He}$ ascended with wonderful rapidity, and in about a minnte he was almost at the top of the tree. He now went off in a side direction, and caught hold of the branch of a neighbouring tree; he then proceeded towards the heart of the forest. I stood looking on, lost in amazement at his singular mode of progress. I followed him with my eye till the intervening branches closed in betwixt us; and then I lost sight for ever of the two-toed sloth. I was going to add, that I never saw a sloth take to his heels in such earnest; but the expression will not do, for the sloth has no heels.

That which naturalists have advanced of his being so tenacious of life is perfectly true. I saw the heart of one beat for half an hour after it was taken out of the body. The wourali-poison seems to be the only thing that will kill it quickly. On reference to a former part of these wanderings, it will be seen that a poisoned arrow killed the sloth in about ten minutes.

So much for this harmless, unoffending animal. He holds a conspicuous place in the catalogue of the animals of the new world. Though naturalists have made no mention of what follows, still it is not less true on that account. The 


\section{WANDERINGS IN SOUTH AMERICA}

sloth is the only quadruped known, which spends its whole life from the branch of a tree, suspended by his feet. I have paid uncommon attention to him in his native haunts. The monkey and squirrel will seize a branch with their fore-feet, and pull themselves up, and rest or run upon it; but the sloth, after seizing it, still remains suspended, and suspended moves along under the branch, till he can lay hold of another. Whenever I have seen him in his native woods, whether at rest, or asleep, or on his travels, I have always observed that he was suspended from the branch of a tree. When his form and anatomy are attentively considered, it will appear evident that the sloth cannot be at ease in any situation, where his body is higher, or above his feet. We will now take our leave of him.

In the far-extending wilds of Guiana, the traveller will be astonished at the immense quantity of Ants which he perceives on the ground and in the trees. They have nests in the branches, four or five times as large as that of the rook; and they have a covered way from them to the ground. In this covered way thousands are perpetually passing and repassing; and if you destroy part of it, they turn to, and immediately repair it.

Other species of ants again have no covered way; but travel, exposed to view, upon the surface of the earth. You will sometimes see a string of these ants a mile long, each earrying in its mouth to its nest a green leaf, the size of a sixpence. It is wonderful to observe the order in which they move, and with what pains and labour they surmount the obstructions of the path. 
The ants have their enemies, as well as the rest of animated nature. Amongst the foremost of these stand the three species of Ant-bears. The smallest is not much larger than a rat; the next is nearly the size of a fox; and the third a stout and powerful animal, measuring about six feet from the snout to the end of the tail. He is the most inoffensive of all animals, and never injures the property of man. He is chiefly found in the inmost recesses of the forest, and seems partial to the low and swampy parts near creeks, where the troely-tree grows. There he goes up and down in quest of ants, of which there is never the least scarcity; so that he soon obtains a sufficient supply of food, with very little trouble. He cannot travel fast; man is superior to him in speed. Without swiftness to enable him to escape from his enemies, without teeth, the possession of which would assist him in self-defence, and without the power of burrowing in the ground, by which he might conceal himself from his pursuers, he still is capable of ranging through these wilds in perfect safety; nor does he fear the fatal pressure of the serpent's fold, or the teeth of the famished jaguar. Nature has formed his fore-legs wonderfully thick, and strong, and muscular, and armed his feet with three tremendous sharp and crooked claws. Whenever he seizes an animal with these formidable weapons, he hugs it close to his body, and keeps it there till it dies through pressure, or through want of food. Nor does the ant-bear, in the meantime, suffer much from loss of aliment, as it is a well-known fact, that he can go longer without food than, perhaps, any other animal, ex- 


\section{WANDERINGS IN SOUTH AMERICA}

cept the land-tortoise. His skin is of a texture that perfectly resists the bite of a dog; his hinder parts are protected by thick and shaggy hair, while his immense tail is large enough to cover his whole body.

The Indians have a great dread of coming in contact with the ant-bear; and after disabling him in the chase, never think of approaching him till he be quite dead. It is perhaps on account of this caution, that naturalists have never yet given to the world a true and correct drawing of this singular animal, or described the peculiar position of his fore-feet when he walks or stands. If, in taking a drawing from a dead ant-bear, you judge of the position in which he stands from that of all other terrestrial animals, the sloth excepted, you will be in error. Examine only a figure of this animal, in books of natural history, or inspect a stuffed specimen in the best museums, and you will see that the fore-claws are just in the same forward attitude as those of a dog, or a common bear when he walks or stands. But this is a distorted and unnatural position; and in life, would be a painful and intolerable attitude for the antbear. The length and curve of his claws cannot admit of such a position. When he walks or stands, his feet have somewhat the appearance of a club-hand. He goes entirely on the outer side of his fore-feet, which are quite bent inwards; the claws collected into a point, and going under the foot. In this position he is quite at ease; while his long claws are disposed of in a manner to render them harmless to him, and are prevented from becoming dull and wor'm, like those of the $\operatorname{dog}$, 


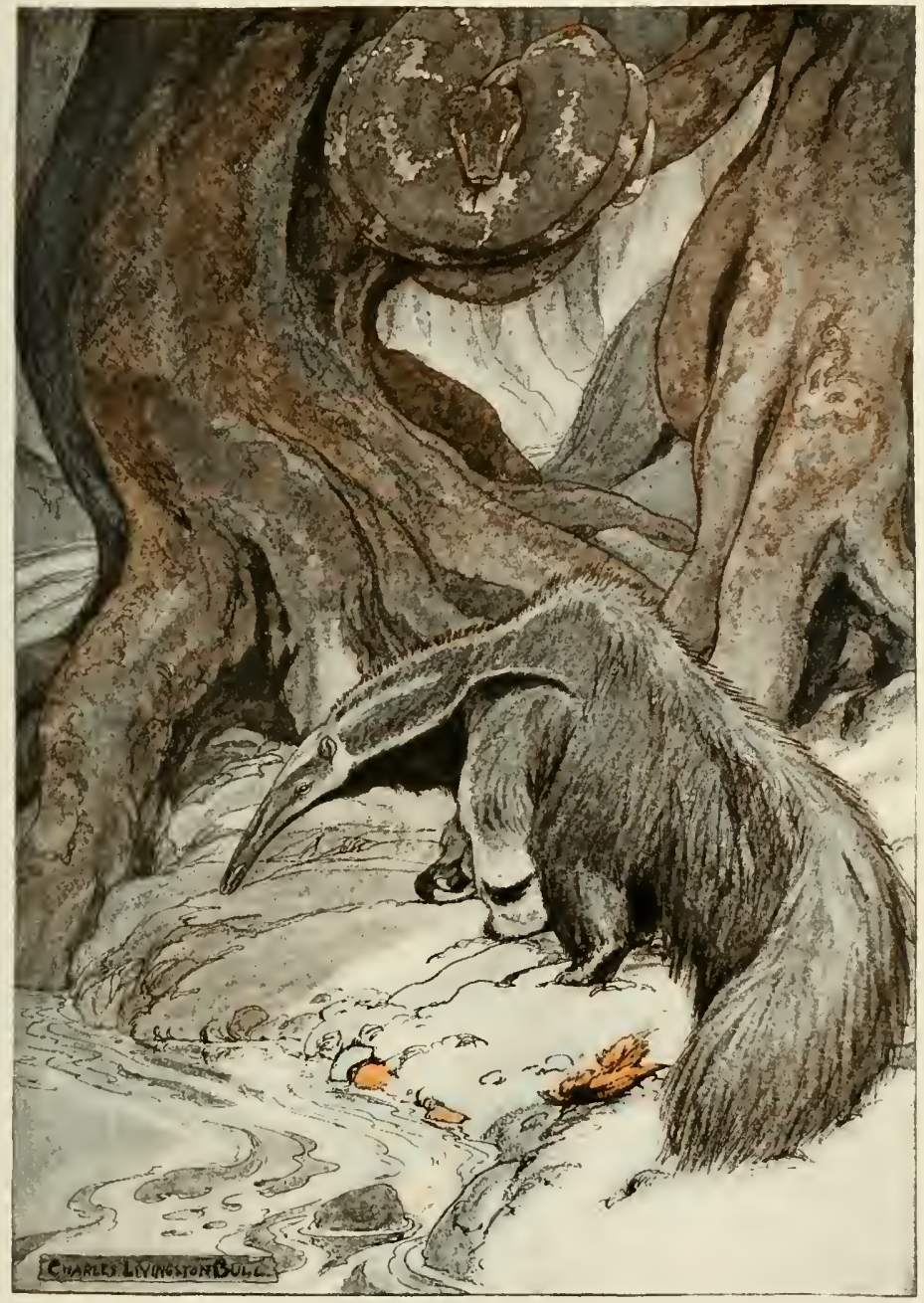

"The Ant-bear is a pacific Animal" 

which would inevitably be the case, did their points come in actual contact with the ground; for his claws have not that retractile power which is given to animals of the feline species by which they are enabled to preserve the sharpness of their claws on the most flinty path. A slight inspection of the fore-feet of the ant-bear, will immediately convince you of the mistake artists and natmralists have fallen into, by putting his forefeet in the same position as those of other quadrupeds; for you will perceive that the whole outer side of his foot is not only deprived of hair, but is hard and callous; proof positive of its being in perpetual contact with the ground. Now, on the contrary, the inner side of the bottom of his foot is soft and rather hairy.

There is another singularity in the anatomy of the ant-bear, I believe, as yet unnoticed in the page of natural history. He has two very large glands situated below the root of the tongue. From these is emitted a glutinous liquid, with which his long tongue is lubricated when he puts it into the ants' nests. These glands are of the same substance as those found in the lower jaw of the woodpecker. The secretion from them, when wet, is very elammy and adhesive, but on being dried it loses these qualities, and you can pulverize it betwixt your finger and thumb; so that, in dissection, if any of it has got upon the fur of the animal, or the feathers of the bird, allow it to dry there, and then it may be removed without leaving the least stain behind.

The ant-bear is a pacific animal. He is never the first to begin the attack. His motto may be, 


\section{WANDERINGS IN SOUTH AMERICA}

"Noli me tangere." As his habits and his haunts differ materially from those of every other animal in the forest, their interests never clash, and thus he might live to a good old age, and die at last in peace, were it not that his flesh is good food. On this account the Indian wages perpetual war against him, and as he cannot escape by flight, he falls an easy prey to the poisoned arrow, shot from the Indian's bow at a distance. If ever he be closely attacked by $\operatorname{dog} \mathrm{s}$, he immediately throws himself on his back, and if he be fortunate enough to catch hold of his enemy with his tremendous claws, the invader is sure to pay for his rashness with the loss of life.

We will now take a view of the vampire. As there was a free entrance and exit to the vampire in the loft where I slept, I had many a fine opportunity of paying attention to this nocturnal surgeon. He does not always live on blood. When the moon shone bright, and the fruit of the bananatree was ripe, I conld see him approach and eat it. He would also bring into the loft, from the forest, a green round fruit, something like the wild guava, and about the size of a nutmeg. There was something also, in the blossom of the sawarri nut-tree, which was grateful to him; for on coming up Waratilla creek, in a moonlight night, I saw several vampires fluttering round the top of the sawarri tree, and every now and then the blossoms, which they had broken off, fell into the water. They certainly did not drop off naturally, for on examining several of them, they appeared quite fresh and blooming. So I concluded the vampires pulled them from the tree, either to get 
at the incipient fruit, or to catch the insects which often take up their abode in flowers.

The vampire, in general, measures about twensix inches from wing to wing, extended, though I once killed one which measured thirty-two inches. He frequents old abandoned houses and hollow trees; and sometimes a cluster of them may be seen in the forest hanging head downwards, from the branch of a tree.

Goldsmith seems to have been aware that tre vampire hangs in clusters; for in the Deserted Village, speaking of America, he says,-

"And matted woods, where birds forget to sing,

But silent bats in drowsy clusters cling."

The vampire has a curious membrane, which rises from the nose, and gives it a very singular appearance. It has been remarked before, that there are two species of vampire in Guiana, a larger and a smaller. The larger sucks men and other animals; the smaller seems to confine himself chiefly to birds. I learnt from a gentleman, high up in the river Demerara, that he was completely unsuccessful with his fowls, on account of the small vampire. He showed me some that had been sucked the night before, and they were scarcely able to walk.

Some years ago $I$ went to the river Paumaron with a Scotch gentleman, by name Tarbet. We hung our hammocks in the thatched loft of a planter's house. Next morning I heard this gentleman muttering in his hammock, and now and then letting fall an imprecation or two, just about the time he ought to have been saying his morn- 


\section{WANDERINGS IN SOUTH AMERICA}

ing prayers. "What is the matter, Sir," said I, softly; "is any thing amiss?" "What's the matter?" answered he, surlily; "why, the vampires have been sucking me to death." As soon as there was light enough, I went to his hammock, and saw it much stained with blood. "There," said he, thrusting his foot out of the hammock, "see how these infernal imps have been drawing my life's blood." On examining his foot, I found the vampire had tapped his great toe: there was a wound somewhat less than that made by a leech; the blood was still oozing from it; I conjectured he might have lost from ten to twelve ounces of blood. Whilst examining it, I think I put him into a worse humour by remarking, that an European surgeon would not have been so generous as to lave blooded him without making a charge. He looked up in my face, but did not say a word: I saw he was of opinion that I had better have spared this piece of ill-timed levity.

It was not the last punishment of this good gentleman in the river Paumaron. The next night he was doomed to undergo a kind of ordeal unknown in Europe. There is a species of large red ant in Guiana, sometimes called Ranger, sometimes Coushie. These ants march in millions through the country, in compact order, like a regiment of soldiers; they eat up every insect in their march; and if a house obstruct their route, they do not turn out of the way, but go quite through it. Though they sting cruelly when molested, the planter is not sorry to see them in his house; for it is but a passing visit, and they destroy every 
kind of insect vermin that has taken shelter under his roof.

Now, in the Brifish plantations of Guiana, as well as in Europe, there is always a little temple dedicated to the goddess Cloacina. Our dinner had chiefly consisted of crabs, dressed in rich and different ways. Paumaron is famous for crabs, and strangers who go thither consider them the greatest luxury. The Scotch gentleman made a very capital dinner on crabs; but this change of diet was productive of unpleasant circumstances: he awoke in the night in that state in which Virgil describes Cæleno to have been, viz. "fædissima ventris proluvies." Up he got, to verify the remark,

"Serius aut eitius, sedem properamus ad unam."

Now, unluckily for himself, and the nocturnal tranquility of the planter's house, just at that unfortunate hour, the Coushie Ants were passing across the seat of Cloacina's temple; be had never dreamed of this; and so, turning his face to the door, he placed himself in the usual situation which the votaries of the goddess generally take. Had a lighted match dropped upon a pound of gunpowder, as he afterwards remarked, it could not have caused a greater recoil. Up he jumped, and forced his way out, roaring for help. and for a light, for he was worried alive by ten thousand devils. The fact is, he had sat down upon an intervening body of coushie ants. Many of those which escaped being crushed to death, turned again, and, in revenge, stung the mintentional intruder most severely. 'The watchman had 


\section{WANDERINGS IN SOUTH AMERICA}

fallen asleep, and it was some time before a light could be procured, the fire having gone out; in the mean time, the poor gentleman was suffering an indescribable martyrdom, and would have found himself more at home in the Augean stable than in the planter's house.

I had often wished to have been once sucked by the vampire, in order that I might have it in my power to say it had really happened to me. There can be no pain in the operation, for the patient is always asleep when the vampire is sucking him; and as for the loss of a few ounces of blood, that would be a trifle in the long run. Many a night have I slept with my foot out of the hammock to tempt this winged surgeon, expecting that he would be there; but it was all in vain; the vampire never sucked me, and I could never account for his not doing so, for we were inhabitants of the same loft for months together.

The armadillo is very common in these forests; he burrows in the sand-hills like a rabbit. As it often takes a considerable time to dig him out of his hole, it would be a long and laborious business to attack each hole indiscriminately without knowing whether the animal were there or not. To prevent disappointment, the Indians carefully examine the mouth of the hole, and put a short stick down it. Now if, on introducing the stick, a number of mosquitos come out, the Indians know to a certainty that the armadillo is in it: wherever there are no mosquitos in the hole there is no armadillo. The Indian having satisfied himself that the armadillo is there, by the mosquitos which come out, he immediately cuts a long 
and slender stick, and introduces it into the hole: he carefully observes the line the stick takes, and then sinks a pit in the sand to catch the end of it: this done, he puts it farther into the hole, and digs another pit, and so on, till at last he comes up with the armadillo, which had been making itself a passage in the sand till it had exhausted all its strength through pure exertion. I have been sometimes three quarters of a day in digging out one armadillo, and obliged to sink half a dozen pits, seven feet deep, before I got up to it. The Indians and negroes are very fond of the flesh, but I considered it strong and rank.

On laying hold of the armadillo you must be cautious not to come in contact with his feet: they are armed with sharp claws, and with them he will inflict a severe wound in self-defence: when not molested, he is very harmless and innocent; he would put you in mind of the hare in Gay's fables,-

"Whose care was never to offend, And every ereature was her friend."

The armadillo swims rell in time of need, but does not go into the water by choice. He is very seldom seen abroad during the day; and when surprised, he is sure to be near the mouth of his hole. Every part of the armadillo is well protected by his shell, except his ears. In life, this shell is very limber, so that the animal is enabled to go at full stretch, or roll himself up into a ball, as occasion may require.

On inspecting the arrangement of the shell, it puts you very much in mind of a coat of armour; 


\section{WANDERINGS IN SOUTH AMERICA}

indeed it is a natural coat of armour to the armadillo, and being composed both of scale and bone, it affords ample security, and has a pleasing effect.

Often, when roving in the wilds, I would fall in with the Land Tortoise; he too adds another to the list of unoffending animals; he subsists on the fallen fruits of the forest. When an enemy approaches he never thinks of moving, but quietly draws himself under his shell, and there awaits his doom in patience: he only seems to have two enemies who can do him any damage; one of these is the Boa Constrictor: this snake swallows the tortoise alive, shell and all. But a boa large enough to do this is very scarce, and thus there is not much to apprehend from that quarter; the other enemy is man, who takes up the tortoise, and carries him away. Man also is scarce in these never-ending wilds, and the little depredations he may commit upon the tortoise will be nothing, or a mere trifle. The tiger's teeth cannot penetrate its shell, nor can a stroke of his paws do it any damage. It is of so compact and strong a nature, that there is a common saying, a London waggon might roll over it and not break it.

Ere we proceed, let us take a retrospective view of the five animals just enumerated; they are all quadrupeds, and have some very particular mark, or mode of existence, different from all other animals. The sloth has four feet, but never can use them, to support his body on the earth; they want soles, which are a marked feature in the feet of other animals. The ant-bear has not a tooth in his head, still he roves fearless on, in the same forests with the Jaguar and boa con- 
strictor. The vampire does not make use of his feet to walk, but to stretch a membrane, which enables him to go up into an element where no other quadruped is seen. The armadillo has only here and there a straggling hair, and has neither fur, nor wool, nor bristles, but in lieu of them has received a movable shell, on which are scales very much like those of fishes. The tortoise is oviparous, entirely without any appearance of hair, and is obliged to accommodate itself to a shell which is quite hard and inflexible, and in no point of view whatever obedient to the will or pleasure of the bearer. The egg of the tortoise has a very hard shell, while that of the turtle is quite soft. 


\section{CHAPTER II}

In some parts of these forests I saw Vanilla growing luxuriantly. It creeps up the trees to the height of thirty or forty feet. I found it difficult to get a ripe pod, as the monkeys are very fond of it, and generally took care to get there before me. The pod hangs from the tree in the shape of a little scabbard. Vayna is the Spanish for a scabbard, and Vanilla for a little scabbard. Hence the name.

In Mibiri creek there was a cayman of the small species, measuring about five feet in length; I saw it in the same place for months, but could never get a shot at it; for the moment I thought I was sure of it, it dived under the water before I could pull the trigger. At last I got an Indian with his bow and arrow; he stood up in the canoe with his bow ready bent, and as we drifted past the place, he sent his arrow into the cayman's eye and killed it dead. The skin of this little species is much harder and stronger than that of the large kind: it is good food, and tastes like veal.

My friend, Mr. Edmonstone, had very kindly let me have one of his old negroes, and he constantly attended me; his name was Daddy Quashi; he had a brave stomach for heterogeneous food; it could digest, and relish too, cayman, monkeys, hawks, and grubs. The Daddy made three or four meals on this cayman while it was not absolutely 


\section{WANDERINGS IN SOUTH AMERICA 197}

putrid, and salted the rest. I could never get him to face a snake; the horror he betrayed on seeing one was beyond description; I asked him why he was so terribly alarmed; he said it was by seeing so many dogs, from time to time, killed by them.

Here I had a fine opportunity of examining several species of the caprimulgus. I am fully persuaded that these innocent little birds never suck the herds; for when they approach them, and jump up at their udders, it is to catch the flies and insects there. When the moon shone bright, I would frequently go and stand within three yards of a cow, and distinctly see the caprimulgus eatch the flies on its udder. On looking for them in the forest, during the day, I either found them on the ground, or else invariably sitting longitudinally on the branch of a tree, not crosswise like all other birds.

The Wasps, or Maribuntas, are great plagues in these forests, and require the naturalist to be cautious as he wander's up and down. Some make their nests pendent from the branches; others have them fixed to the underside of a leaf. Now in passing on, if you happen to disturb one of these, they sally forth and punish you severely. The largest kind is blue; it brings blood where its sting enters, and causes pain and inflammation enough to create a fever. The Indians make a fire under the nest, and after killing or driving away the old ones, they roast the young grubs in the comb and eat them. I tried them once by way of dessert after dinner, but my stomach was offended at their intrusion; probably it was more 
the idea than the taste that caused the stomach to rebel.

Time and experience have convinced me that there is not much danger in roving amongst snakes and wild beasts, provided only that you have self-command. You must never approach them abruptly; if so, you are sure to pay for your rashness; because the idea of self-defence is predominant in every animal, and thus the snake, to defend himself from what he considers an attack upon him, makes the intruder feel the deadly effect of his poisonous fangs. The jaguar flies at you and knocks you senseless with a stroke of his paw: whereas, if you had not come upon him too suddenly, it is ten to one but that he had retired, in lien of disputing the path with you. The labarri snake is very poisonous, and I have often approached within two yards of him without fear. I took care to move very softly and gently without moving my arms, and he always allowed me to have a fine view of him, without showing the least inclination to make a spring at me. He would appear to keep his eye fixed on me, as though suspicious, but that was all. Sometimes I have taken a stick ten feet long, and placed it on the labarri's back. He would then glide away without offering resistance. But when I put the end of the stick abruptly to his head, he immediately opened his mouth, flew at it, and bit it.

One day, wishful to see how the poison comes out of the fangs of the snake, I caught a labarri alive. He was about eight feet long. I held him by the neck, and my hand was so near his jaw, 
that he had not room to move his head to bite it. This was the only position I could have held him in with safety and effect. To do so, it only required a little resolution and coolness. I then took a small piece of stick in the other hand, and pressed it against the fang, which is invariably in the upper jaw. Towards the point of the fang, there is a little oblong aperture on the convex side of it. Through this, there is a communication down the fang to the root, at which lies a little bag containing the poison. Now, when the point of the fang is pressed, the root of the fang also presses against the bag, and sends up a portion of the poison therein contained. Thus, when I applied a piece of stick to the point of the fang, there came out of the hole a liquor thick and yellow, like strong camomile tea. This was the poison which is so dreadful in its effects, as to render the labarri snake one of the most poisonous in the forests of Guiana. I once caught a fine labarri, and made it bite itself. I forced the poisonous fang into its belly. In a few minutes I thought it was going to die, for it appeared dull and heavy. However, in half an hour's time, he was as brisk and vigorous as ever, and in the course of the day showed no symptoms of being affected. Is then the life of the snake proof against its own poison? This subject is not unworthy of the consideration of the naturalist.

In Guiana there is a little insect in the grass and on the shrubs, which the French call Bêterouge. It is of a beautiful scarlet colour, and so minute, that you must bring your eye close to it before you can perceive it. It is most numerous 
in the rainy season. Its bite causes an intolerable itching. The best way to get rid of it, is to rub the part affected with oil or rum. You must be careful not to scratch it. If you do so, and break the skin, you expose yourself to a sore. The first year I was in Guiana, the bête-rouge, and my own want of knowledge, and, I may add, the little attention I paid to it, created an ulcer above the ankle, which annoyed me for six months, and if I hobbled ont into the grass, a number of bête-rouge would settle on the edges of the sore, and increase the inflammation.

Still more inconvenient, painful, and annoying is another little pest, called the Chegoe. It looks exactly like a very small flea, and a stranger would take it for one. However, in about four and twenty hours, he would have several broad lints that he had made a mistake in lis ideas of the animal. It attacks different parts of the body, but chiefly the feet, betwixt the toe-nails and the flesh. There it buries itself, and at first causes an itching not unpleasant. In a day or so, after examining the part, you perceive a place about the size of a pea, somewhat discolonred, rather of a blue appearance. Sometimes it happens that the itching is so trivial. you are not aware that the miner is at work. Time, they say, makes great discoveries. The discoloured part turns out to be the nest of the chegoe containing hundreds of eggs, which, if allowed to hatch there, the young ones will soon begin to form other nests, and in time cause a spreading ulcer. As soon as you perceive that you have got the chegoe in your flesh, you must take a needle, or a sharp-pointed 
knife, and take it out. If the nest be formed, great care must be taken not to break it, otherwise some of the eggs remain in the flesh, and then you will soon be annoyed with more chegoes. After removing the nest, it is well to drop spirit of turpentine into the hole; that will most effectually destroy any chegoe that may be lurking there. Sometimes I have taken four nests out of my feet in the course of the day.

Every evening, before sundown, it was part of my toilette to examine my feet, and see that they were clear of chegoes. Now and then a nest would escape the scrutiny, and then I had to smart for it a day or two after. A chegoe once lit upon the back of my hand; wishful to see how he worked, I allowed him to take possession. He immediately set to work, head foremost, and in about half an hour he had completely buried himself in the skin. I then let him feel the point of my knife, and exterminated him.

Nore than once, after sitting down upon a rotten stump, I have found myself covered with Ticks. There is a short and easy way to get quit of these unwelcome adherents. Make a large fire and stand close to it, and if you be covered with ticks, they will all fall off.

Let us now forget for a while the quadrupeds, serpents, and insects, and take a transitory view of the native Tndians of these forests.

There are five mrincipal nations or tribes of Indians in ci-devant Dutch Guiana, commonly known by the name of Warow, Arowack, Acoway, Carib, and Macoushi. They live in small hamlets, which consist of a few huts, never exceeding 
twelve in number. These huts are always in the forest, near a river or some creek. They are open on all sides (except those of the Macoushi), and covered with a species of palm leaf.

Their principal furniture is the hammock. It serves them both for chair and bed. It is commonly made of cotton; though those of the Warows are formed from the ata tree. At night they always make a fire close to it. The heat keeps them warm, and the smoke drives away the mosquitos and sand-flies. You sometimes find a table in the hut; but it was not made by the Indians, but by some negro, or mulatto carpenter.

They cut down about an acre or two of the trees which surround the huts, and there plant Pepper, Papaws, Sweet and Bitter Cassava, Plantains, Sweet Potatoes, Yams, Pine-Apples, and Silk-Grass. Besides these, they generally have a few acres in some fertile part of the forest for their cassava, which is as bread to them. They make earthen pots to boil their provisions in; and they get from the white men flat circular plates of iron, on which they bake their cassava. They have to grate the cassava before it is pressed, preparatory to baking; and those Indians who are too far in the wilds to procure graters from the white men, make use of a flat piece of wood, studded with sharp stones. They have no cows, horses, mules, goats, sheep, or asses. The men hunt and fish, and the women work in the provision ground, and cook their victuals.

In each hamlet there is the trunk of a large tree, hollowed out like a trough. In this, from their cassava, they make an abominable ill-tasted and 
sour kind of fermented liquor, called piwarri. They are very fond of it, and never fail to get drunk after every brewing. The frequency of the brewing depends upon the superabundance of cassava.

Both men and women go without clothes. The men have a cotton wrapper, and the women a beadornamented square piece of cotton, about the size of your hand, for the fig-leaf. Those far away in the interior, use the bark of a tree for this purpose. They are very clean people, and wash in the river, or creek, at least twice every day. They paint themselves with the roucou, sweetly perfumed with hayawa or accaiari. Their hair is black and lank, and never curled. The women braid it up fancifully, something in the shape of Diana's head-dress in ancient pictures. They have very few diseases. Old age and pulmonary complaints seem to be the chief agents for removing them to another world. The pulmonary complaints are generally brought on by a severe cold, which they do not know how to arrest in its progress, by the use of the lancet. I never saw an idiot amongst them, nor could I perceive any that were deformed from their birth. Their women never perish in childbed, owing, no doubt, to their never wearing stays.

They have no public religious ceremony. They acknowledge two superior beings,--a good one, and a bad one. They pray to the latter not to hurt them, and they are of opinion that the former is too good to do them an injury. I suspect, if the truth were known, the individuals of the village never offer up a single prayer or ejaculation. 


\section{WANDERINGS IN SOUTH AMERICA}

They have a kind of a priest called a Pee-ay-man, who is an enchanter. He finds out things lost. He mutters prayers to the evil spirit over them and their children when they are sick. If a fever be in the village, the Pee-ay-man goes about all night long, howling, and making dreadful noises, and begs the bad spirit to depart. But he has very seldom to perform this part of his duty, as fevers seldom visit the Indian hamlets. However, when a fever does come, and his incantations are of no avail, which I imagine is most commonly the case, they abandon the place for ever, and make a new settlement elsewhere. They consider the owl and the goatsucker as familiars of the evil spirit, and never destroy them.

I could find no monuments or marks of antiquity amongst these Indians; so that after penetrating to the Rio Branco, from the shores of the Western Ocean, had any body questioned me on this subject, I should have answered, I have seen nothing amongst these Indians which tells me that they have existed here for a century; though, for aught I know to the contrary, they may have been here before the Redemption, but their total want of civilization has assimilated them to the forests in which they wander. Thus, an aged tree falls and moulders into dust and you cannot tell what was its appearance, its beauties, or its diseases amongst the neighbouring trees; another has shot up in its place, and after nature has had her course, it will make way for a successor in its turn. So it is with the Indian of Guiana; he is now laid low in the dust; he has left no record behind him, either on parchment, 
or on a stone, or in earthenware, to say what he has done. Perhaps the place where his buried ruins lie was unhealthy, and the survivors have left it long ago, and gone far away into the wilds. All that you can say is, the trees where I stand appear lower and smaller than the rest, and from this I conjecture, that some Indians may have had a settlement here formerly. Were I by chance to meet the son of the father who moulders here, he could tell me that his father was famous for slaying tigers and serpents and caymen, and noted in the chase of the tapir and wild boar, but that he remembers little or nothing of his grandfather.

They are very jealous of their liberty, and much attached to their own mode of living. Though those in the neighbourhood of the European settlements have constant communication with the whites, they have no inclination to become civilized. Some Indians who have accompanied white men to Europe, on returning to their own land, have thrown off their clothes, and gone back into the forests.

In George-town, the capital of Demerara, there is a large shed, open on all sides, built for them by order of government. Hither the Indians come with monkies, parrots, bows and arrows, and pegalls. They sell these to the white men for money, and too often purchase rum with it, to which they are wonderfully addicted.

Government allows them annual presents in order to have their services, when the colony deems it necessary to scour the forests in quest of runaway negroes. Formerly these expeditions were headed by Charles Edmonstone, Esq., now 
of Cardross Park, near Dumbarton. This brave colonist never returned from the woods without being victorious. Once, in an attack upon the rebel negroes' camp, he led the way, and received two balls in his body; at the same moment that he was wounded, two of his Indians fell dead by his side; he recovered after his life was despaired of, but the balls could never be extracted.

Since the above appeared in print, I have had the account of this engagement with the negroes in the forest from Mr. Edmonstone's own mouth.

$\mathrm{He}$ received four slugs in his body, as will be seen in the sequel.

The plantations of Demerara and Essequibo are bounded by an almost interminable extent of forest. Hither the runaway negroes repair, and form settlements, from whence they issue to annoy the colonists, as occasion may offer.

In 1801, the runaway slaves had increased to an alarming extent. The Governor gave orders that an expedition should be immediately organized, and proceed to the woods, under the command of Charles Edmonstone, Esq. General Hislop sent him a corporal, a sergeant, and eleven men, and he was joined by a part of the colonial militia, and by sixty Indians.

With this force Mr. Edmonstone entered the forest, and proceeded in a direction towards Mahaica.

He marched for eight days through swamps, and over places obstructed by fallen trees and the bush-rope; tormented by myriads of mosquitos, and ever in fear of treading on the 
poisonous snakes, which can scarcely be distinguished from the fallen leaves.

At last he reached a wooded sand-hill, where the Maroons had intrenched themselves in great force. Not expecting to come so soon upon them, Mr. Edmonstone, his faithful man Coffee, and two Indian chiefs, found themselves considerably ahead of their own party. As yet, they were unperceived by the enemy, but, unfortunately, one of the Indian chiefs fired a random shot at a distant Maroon. Immediately the whole negro camp turned out, and formed themselves in a crescent, in front of Mr. Edmonstone. Their chief was an uncommonly fine negro, about six feet in height; and his head-dress was that of an African warrior, ornamented with a profusion of small shells. He advanced undauntedly with his gun in his hand, and, in insulting language, called out to Mr. Edmonstone to come on and fight him.

Mr. Edmonstone approached him slowly, in order to give his own men time to come up; but they were yet too far off for him to profit by this manœuvre. Coffee, who carried his master's gun, now stepped up behind him, and put the gun into his hand, which Mr. Edmonstone received, without advancing it to his shoulder.

He was now within a few yards of the Maroon chief, who seemed to betray some symptoms of uncertainty; for instead of firing directly at $\mathrm{Mr}$. Edmonstone, he took a step sideways, and rested his gun against a tree; no doubt with the intention of taking a surer aim. Mr. Edmonstone, on perceiving this, immediately cocked his gun, and 
fired it off, still holding it in the position in which he had received it from Coffee.

The whole of the contents entered the negro's body, and he dropped dead on his face.

The negroes, who had formed in a crescent, now in their turn fired a volley, which brought Mr. Edmonstone and his two Indian chiefs to the ground. The Maroons did not stand to reload, but on Mr. Edmonstone's party coming up, they fled precipitately into the surrounding forest.

Four slugs had entered Mr. Edmonstone's body. After coming to himself, on looking around, he saw one of the fallen Indian chiefs bleeding by his side. He accosted him by name, and said he hoped he was not much hurt. The dying Indian had just strength enough to answer, "Oh no,"-and then expired. The other chief was lying quite dead. He must have received his mortal wound just as he was in the act of cocking his gun to fire on the negroes; for it appeared that the ball which gave him his death wound, had carried off the first joint of his thumb, and passed through his forehead. By this time his wife, who had accompanied the expedition, came up. She was a fine young woman, and had her long black hair fancifully braided in a knot on the top of her head, fastened with a silver ornament. She unloosed it, and, falling on her husband's body, covered it with her hair, bewailing his untimely end with the most heartrending cries.

The blood was now running out of Mr. Edmonstone's shoes. On being raised up, he ordered his men to pursue the flying Maroons, requesting at the same time that he might be left where he 
had fallen, as he felt that he was mortally wounded. They gently placed him on the ground, and after the pursuit of the Maroons had ended, the corporal and sergeant returned to their commander, and formed their men. On his asking what this meant, the sergeant replied, "I had the Aeneral's orders, on setting out from town, not to leave you in the forest, happen what might." By slow and careful marches, as much as the obstructions in the woods would admit of, the party reached Plantation Alliance, on the bank of the Demerara, and from thence it crossed the river to Plantation Vredestein.

The news of the rencounter had been spread far and wide by the Indians, and had already reached town. The General, Cantains Macrai and Jolinstone, and Doctor Dunkin, proceeded to Vredestein. On examining Mr. Edmonstone's wounds, four slugs were found to have entered the body; one was extracted, the rest remained there till the year 1824, when another was cut out by a professional gentleman of Port Glasgow. The other two still remain in the body; and it is supposed that either one or both have touched a nerve, as they cause almost continual pain. Mr. Edmonstone has commanded fifteen different expeditions in the forest in quest of the Maroons. The Colonial Government has requited his services, by freeing his property from all taxes, and presenting him a handsome sword, and a silver urn, bearing the following inscription:

"Presented to Charles Edmonstone, Esq., by the Governor and Court of Policy of the Colony of Demerara, as a token of their esteem, and the deep sense they entertain of the very great 


\section{WANDERINGS IN SOUTH AMERICA}

activity and spirit manifested by him on various occasions in his successful exertions for the internal security of the Colony.January 1st, 1809.',

I do not believe that there is a single Indian in ci-devant Dutch Guiana who can read or write, nor am I aware that any white man has reduced their language to the rules of grammar; some may have made a short manuscript vocabulary of the few necessary words, but that is all. Here and there a white man, and some few people of colour, talk the language well. The temper of the Indian of Guiana is mild and gentle, and he is very fond of his children.

Some ignorant travellers and colonists call these Indians a lazy race. Man in general will not be active without an object. Now when the Indian has caught plenty of fish, and killed game enough to last him for a week, what need has he to range the forest? He has no idea of making pleasure-grounds. Money is of no use to him, for in these wilds there are no markets for him to frequent, nor milliners' shops for his wife and daughters; he has no taxes to pay, no highways to keep up, no poor to maintain, nor army nor navy to supply; he lies in his hammock both night and day (for he has no chair or bed, neither does he want them), and in it he forms his bow, and makes his arrows, and repairs his fishing tackle. But as soon as he has consumed his provisions, he then rouses himself, and, like the lion, scours the forest in quest of food. He plunges into the river after the deer and tapir, and swims across it; passes through swamps and quagmires, and never fails to obtain a sufficient supply of 
food. Should the approach of night stop his career, while he is hunting the wild boar, he stops for the night, and continues the chase the next morning. In my way through the wilds to the Portuguese frontier, I had a proof of this: we were eight in number, six Indians, a negro, and myself. About ten o'clock in the morning, we observed the feet-mark of the wild boars; we judged by the freshness of the marks that they had passed that way early the same morning. As we were not gifted, like the hound, with scent, and as we had no dog with us, we followed their track by the eye. The Indian after game is as sure with his eye as the dog is with his nose. We followed the herd till three in the afternoon, then gave up the chase for the present; made our fires close to a creek where there was plenty of fish, and then arranged the hammocks. In an hour the Indians shot more fish with their arrows than we could consume. The night was beautifully serene and clear, and the moon shone as bright as day. Next morn we rose at dawn, got breakfast, packed up, each took his burden, and then we put ourselves on the track of the wild boars, which we had been following the day before. We supposed that they, too, would sleep that night in the forest, as we had done; and thus the delay on our part would be no disadvantage to us. This was just the case, for about nine o'clock their feet-marks became fresher and fresher: we now doubled our pace, but did not give mouth like hounds. We pushed on in silence, and soon came up with them; they were above one hundred of them; we killed six, and the rest 


\section{WANDERINGS IN SOU'TH AMERICA}

took off in different directions. But to the point.

Amongst us the needy man works from light to dark for a maintenance. Should this man chance to acquire a fortune, he soon changes his habits. No longer under "strong necessity's supreme command," he contrives to get out of bed betwixt nine and ten in the morning. His servant helps him to dress, he walks on a soft carpet to his breakfast table, his wife pours out his tea, and his servant hands him his toast. After breakfast, the doctor advises a little gentle exercise in the carriage for an hour or so. At dinner-time he sits down to a table groaning beneath the weight of heterogeneous luxury: there he rests upon a chair for three or four hours, eats, drinks, and talks (often unmeaningly) till tea is announced. He proceeds slowly to the drawing-room, and there spends the best part of his time in sitting, till his wife tempts him with something warm for supper. After supper, he still remains on his chair at rest, till he retires to rest for the night. He mounts leisurely up stairs upon a carpet, and enters his bed-room: there, one would hope, that at least he mutters a praver or: two, though perhaps not on bended knee: he then lets himself drop into a soft and downy bed, over which has just passed the comely Jenny's warming-pan. Now, could the Indian in his turn see this, he would call the white men a lazy, indolent set.

Perhaps then, upon due reflection, you would draw this conclusion; that men will always be indolent where there is no object to rouse them.

As the Indian of Guiana has no idea whatever 
of communicating his intentions by writing, he has fallen upon a plan of communication sure and simple. When two or three families have determined to come down the river and pay you a visit, they send an Indian beforehand with a string of beads. You take one bead off every day; and on the day that the string is beadless, they arrive at your house.

In finding their way through these pathless wilds, the sun is to them what Ariadne's clue was to Theseus. When he is on the meridian, they generally sit down, and rove onwards again as soon as he has sufficiently declined to the west; they require no other compass. When in chase, they break a twig on the bushes as they pass by every three or four hundred paces, and this often prevents them from losing their way on their return.

You will not be long in the forests of Guiana, before you perceive how very thinly they are inhabited. You may wander for a week together without seeing a hut. The wild beasts, snakes, the swamps, the trees, the uncurbed luxuriance of everything around you, conspire to inform you that man has no habitation here-man has seldom passed this way. 


\section{CHAPTER III}

Let us now return to natural history. There was a person making shingles, with twenty or thirty negroes, not far from Mibiri-hill. I had offered a reward to any of them who would find a good-sized snake in the forest, and come and let me know where it was. Often had these negroes looked for a large snake, and as often been disappointed.

One Sunday morning I met one of them in the forest, and asked him which way he was going: he said he was going towards Warratilla creek to hunt an armadillo: and he had his little dog with him. On coming back, about noon, the dog began to bark at the root of a large tree, which had been upset by the whirlwind, and was lying there in a gradual state of decay. The negro said, he thought his dog was barking at an acouri, which had probably taken refuge under the tree, and he went up with an intention to kill it: he there saw a snake, and hastened back to inform me of it.

The sun had just passed the meridian in a cloudless sky; there was scarcely a bird to be seen, for the winged inhabitants of the forest, as though overcome by heat, had retired to the thickest shade: all would have been like midnight silence, were it not for the shrill voice of the Pi-pi-yo, every now and then resounding from a distant tree. I was sitting with a little Horace 
in my hand, on what had once been the steps which formerly led up to the now mouldering and dismantled building. The negro and his little dog came down the hill in haste, and I was soon informed that a snake had been discovered; but it was a young one, called the Bush-master, a rare and poisonous snake.

I instantly rose up, and laying hold of the eight-foot lance, which was close by me, "Well then, Daddy," said I, "we'll go and have a look at the snake." I was barefoot, with an old hat, and check shirt, and trousers on, and a pair of braces to keep them up. The negro had his cutlass, and as we ascended the hill, another negro, armed with a cutlass, joined us, judging, from our pace, that there was something to do. The little dog came along with us, and when we had got about half a mile in the forest, the negro stopped, and pointed to the fallen tree: all was still and silent: I told the negroes not to stir from the place where they were, and keep the little $\operatorname{dog}$ in, and that I would go in and reconnoitre.

I advanced up to the place slow and cautious. The snake was well concealed, but at last I made him out; it was a Coulacanara, not poisonous, but large enough to have crushed any of us to death. On measuring him afterwards, he was something more than fourteen feet long.

This species of snake is very rare, and much thicker, in "proportion to his length, than any other snake in the forest. A coulacanara of fourteen feet in length is as thick as a common boa of twenty-four. After skinning this snake I could 


\section{WANDERINGS IN SOUTH AMERICA}

easily get my head into his mouth, as the singular formation of the jaws admits of wonderful extension.

A Dutch friend of mine, by name Brouwer, killed a Boa, twenty-two feet long, with a pair of stag's horns in his mouth: he had swallowed the stag, but could not get the horms down: so he had to wait in patience with that uncomfortable mouthful till his stomach digested the body, and then the horns would drop out. In this plight the Dutchman found him as he was going in his canoe up the river, and sent a ball through his head.

On ascertaining the size of the serpent which the negro had just found, I retired slowly the way I came, and promised four dollars to the negro who had shown it to me, and one to the other who had joined us. Aware that the day was on the decline, and that the approach of night would be detrimental to the dissection, a thought struck me that I could take him alive. I imagined if I could strike him with the lance behind the head, and pin him to the ground, I might succeed in capturing him. When I told this to the negroes, they begged and entreated me to let them go for a gun, and bring more force, as they were sure the snake would kill some of us.

I had been at the siege of Troy for nine rears, and it would not do now to carry back to Greece, "nil decimo nisi dedecus anno." I mean, I had been in search of a large serpent for years, and now having come up with one, it did not become me to turn soft. So, taking a cutlass from one of the negroes, and then ranging both the sable 
slaves behind me, I told them to follow me, and that I would cut them down if they offered to fly. I smiled as I said this, but they shook their heads in silence, and seemed to have but a bad heart of it.

When we got up to the place, the serpent had not stirred, but I could see nothing of his head, and I judged by the folds of his body that it must be at the farthest side of his den. A species of woodbine had formed a complete mantle over the branches of the fallen tree, almost impervious to the rain, or the rays of the sun. Probably he had resorted to this sequestered place for a length of time, as it bore marks of an ancient settlement.

I now took my knife, determining to cut away the woodbine, and break the twigs in the gentlest manner possible, till I could get a view of his head. One negro stood guard close behind me with the lance; and near him the other with a cutlass. The cutlass which I had taken from the first negro was on the ground close by me in case of need.

After working in dead silence for a quarter of an hour, with one knee all the time on the ground, I had cleared away enough to see his head. It appeared coming out betwixt the first and second coil of his body, and was flat on the ground. This was the very position I wished it to be in.

I rose in silence and retreated very slowly, making a sign to the negroes to do the same. The dog was sitting at a distance in mute observance. I could now read in the face of the negroes, that they considered this a very unpleasant affair; and they made another attempt to persuade me to let 


\section{WANDERINGS IN SOUTH AMERICA}

them go for a gun. I smiled in a good-natured manner, and made a feint to cut them down with the weapon I had in my hand. This was all the answer I made to their request, and they looked very uneasy.

It must be observed, we were now about twenty yards from the snake's den. I now ranged the negroes behind me, and told him who stood next to me to lay hold of the lance the moment I struck the snake, and that the other must attend my movements. It now only remained to take their cutlasses from them, for I was sure, if I did not disarm them, they would be tempted to strike the snake in time of danger, and thus for ever spoil his skin. On taking their cutlasses from them, if I might judge from their physiognomy, they seemed to consider it as a most intolerable act of tyranny in me. Probably nothing kept them from bolting, but the consolation that I was to be betwixt them and the snake. Indeed, my own heart, in spite of all I could do, beat quicker than usual; and I felt those sensations which one has on board a merchant-vessel in war time, when the captain orders all hands on deck to prepare for action, while a strange vessel is coming down upon us under suspicious colours.

We went slowly on in silence, without moving our arms or heads, in order to prevent all alarm as much as possible, lest the snake should glide off, or attack us in self-defence. I carried the lance perpendicularly before me, with the point about a foot from the ground. The snake had not moved; and on getting up to him, I struck him with the lance on the near side, just behind 
the neck, and pinned him to the ground. That moment, the negro next to me seized the lance, and held it firm in its place, while I dashed head foremost into the den to grapple with the snake, and to get hold of his tail before he could do any mischief.

On pinning him to the ground with the lance, he gave a tremendous loud hiss, and the little dog ran away, howling as he went. We had a sharp fray in the den, the rotten sticks flying on all sides, and each party struggling for superiority. I called out to the second negro to throw himself upon me, as I found I was not heavy enough. He did so, and the additional weight was of great service. I had now got firm hold of his tail; and after a violent struggle or two, he gave in, finding himself overpowered. This was the moment to secure him. So, while the first negro continued to hold the lance firm to the ground, and the other was helping me, I contrived to unloose my braces, and with them tied up the snake's mouth.

The snake now finding himself in an unpleasant situation, tried to better himself, and set resolutely to work, but we overpowered him. We contrived to make him twist himself round the shaft of the lance, and then prepared to convey him out of the forest. I stood at his head and held it firm under my arm, one negro supported the belly, and the other the tail. In this order we began to move slowly towards home, and reached it after resting ten times; for the snake was too heavy for us to support him without stopping to recruit our strength. As we pro- 
ceeded onwards with him, he fought hard for freedom, but it was all in vain. The day was now too far spent to think of dissecting him. Had I killed him, a partial putrefaction would have taken place before morning. I had brought with me up into the forest a strong bag, large enough to contain any animal that I should want to dissect. I considered this the best mode of keeping live wild animals when I was pressed for daylight; for the bag yielding in every direction to their efforts, they would have nothing solid or fixed to work on, and thus would be prevented from making a hole through it. I say fixed, for after the mouth of the bag was closed, the bag itself was not fastened or tied to anything, but moved about wherever the animal inside caused it to roll. After securing afresh the mouth of the coulacanara, so that he could not open it, he was forced into this bag, and left to his fate till morning.

I cannot say he allowed me to have a quiet night. My hammock was in the loft just above him, and the floor betwixt us, half gone to decay, so that in parts of it no boards intervened betwixt his lodging-room and mine. He was very restless and fretful; and had Medusa been my wife, there could not have been more continued and disagreeable hissing in the bedchamber that night. At daybreak, $T$ sent to borrow ten of the negroes who were cutting wood at a distance; I could have done with half that number, but judged it most prudent to have a good force, in case he should try to escape from the house when we opened the bag. However, nothing serious occurred. 


\section{WANDERINGS IN SOUTH AMERICA 221}

We untied the mouth of the bag, kept him down by main force, and then I cut his throat. He bled like an ox. By six o'clock the same evening, he was completely dissected. On examining his teeth, I observed that they were all bent like tenter-hooks, pointing down his throat, and not so large or strong as I expected to have found them; but they are exactly suited to what they are intended by nature to perform. The snake does not masticate his food, and thus the only service his teeth have to perform is to seize his prey, and hold it till he swallows it whole.

In general, the skins of snakes are sent to museums without the head: for when the Indians and Negroes kill a snake, they seldom fail to cut off the head, and then they run no risk from its teeth. When the skin is stuffed in the museum, a wooden head is substituted, armed with teeth which are large enough to suit a tiger's jaw; and this tends to mislead the spectator, and give him erroneous ideas.

During this fray with the serpent, the old negro, Daddy Quashi, was in George-town procuring provisions, and just returned in time to help to take the skin off. He had spent best part of his life in the forest with his old master, Mr. Edmonstone, and amused me much in recounting their many adventures amongst the wild beasts. The Daddy had a particular horror of snakes, and frankly declared he could never have faced the one in question.

The week following, his courage was put to the test, and he made good his words. It was a curious conflict, and took place near the spot 


\section{WANDERINGS IN SOUTH AMERICA}

where I had captured the large snake. In the morning I had been following a new species of paroquet, and the day being rainy, I had taken an umbrella to keep the gun dry, and had left it under a tree; in the afternoon I took Daddy Quashi with me to look for it. Whilst he was searching about, curiosity took me towards the place of the late scene of action. There was a path where timber had formerly been dragged along. Here I observed a young coulacanara, ten feet long, slowly moving onwards; I saw he was not thick enough to break my arm in case he got twisted round it. There was not a moment to be lost. I laid hold of his tail with the left hand, one knee being on the ground; with the right I took my hat, and held it as you would hold a shield for defence. The snake iustantly turned, and came on at me, with his head about a yard from the ground, as if to ask me, what business I had to take liberties with his tail. I let him come, hissing and open-mouthed, within two feet of $\mathrm{my}$ face, and then, with all the force I was master of, I drove my fist, shielded by my hat, full in his jaws. He was stunned and confounded by the blow, and ere he could recover himself, I had seized his throat with both hands, in such a position that he could not bite me; I then allowed him to coil himslf round my body, and marched off with him as my lawful prize. He pressed me hard, but not alarmingly so.

In the meantime, Daddy Quashi having found the umbrella, and having heard the noise which the fray occasioned, was coming cautiously up. As soon as he saw me, and in what company I 


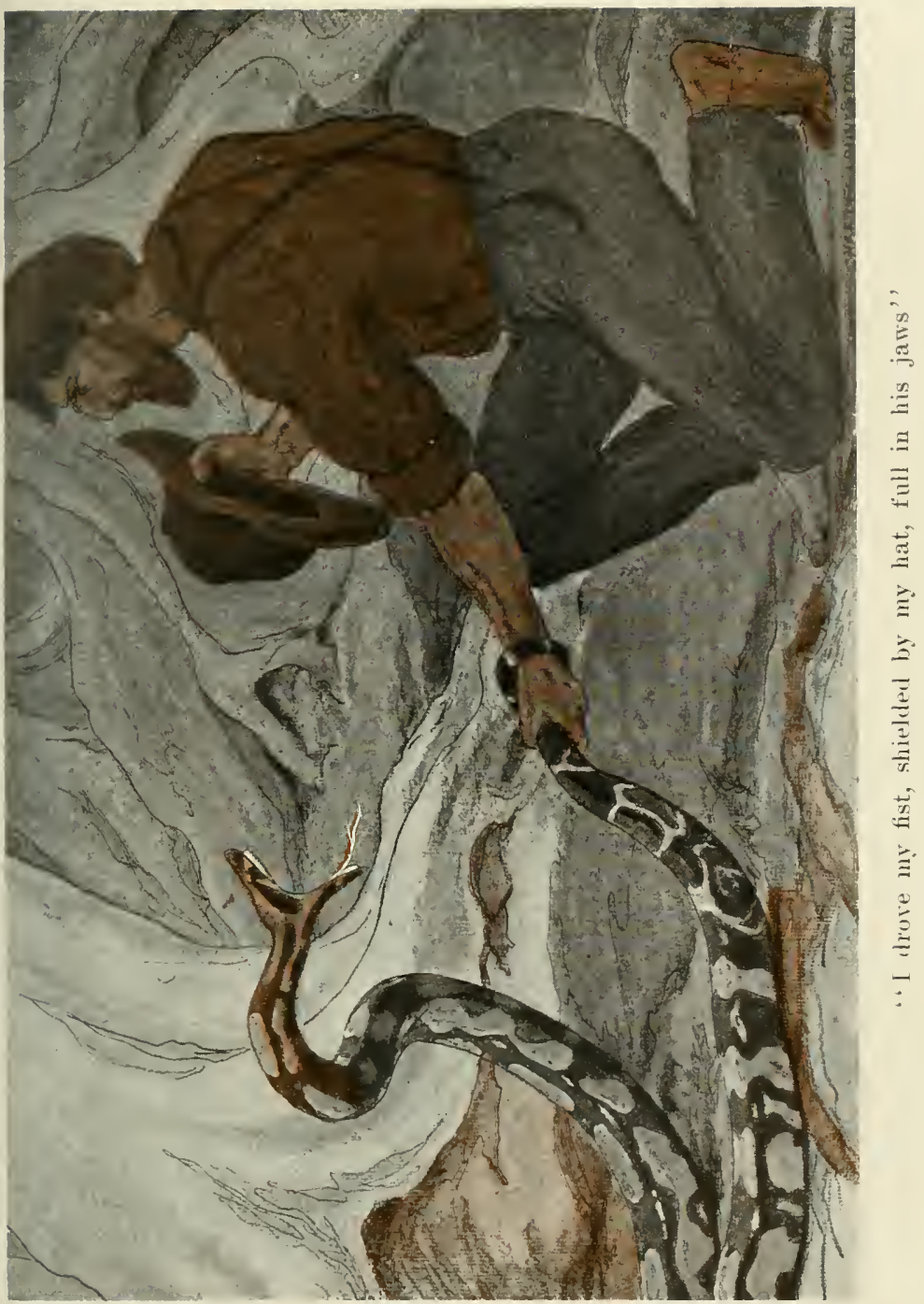





\section{WANDERINGS IN SOUTH AMERICA 223}

was, he turned about and ran off home, I after him, and shouting to increase his fear. On scolding him for his cowardice, the old rogue begged that I would forgive him, for that the sight of the snake had positively turned him sick at stomach.

When I had done with the carcass of the large snake, it was conveyed into the forest, as I expected that it would attract the king of the vultures, as soon as time should have rendered it sufficiently savoury. In a few days it sent forth that odour which a carcass should send forth, and about trenty of the common vultures came and perched on the neighbouring trees; the king of the vultures came too; and I observed that none of the common ones seemed inclined to begin breakfast till his majesty had finished. When he had consumed as much snake as nature informed him would do him good, he retired to the top of a high mora-tree, and then all the common vultures fell to, and made a hearty meal.

The head and neck of the king of the vultures are bare of feathers; but the beautiful appearance they exhibit fades in death. The throat and the back of the neck are of a fine lemon colour; both sides of the neck, from the ears downwards, of a rich scarlet; behind the corrugated part there is a white spot. The crown of the head is scarlet; betwixt the lower mandible and the eye, and close by the ear, there is a part which has a fine silvery blue appearance; the corrugated part is of a dirty light brown; behind it, and just above the white spot, a portion of the skin is blue, and the rest scarlet; the skin which juts out behind the 


\section{WANDERINGS IN SOUTH AMERICA}

neck, and appears like an oblong cartuncle, is blue in part, and part orange.

The bill is orange and black, the caruncles on his forehead orange, and the cere orange; the orbits scarlet, and the irides white. Below the bare part of the neck there is a cinereous ruff. The bag of the stomach, which is only seen when distended with food, is of a most delicate white, intersected with blue veins, which appear on it just like the blue veins on the arm of a faircomplexioned person.

The tail and long wing-feathers are black, the belly white, and the rest of the body a fine satin colour.

I cannot be persuaded that the vultures ever feed upon live animals, not even upon lizards, rats, mice, or frogs; I have watched them for hours together, but never could see them touch any living animals, though innumerable lizards, frogs, and small birds swarmed all around them. I have killed lizards and frogs, and put them in a proper place for observation; as soon as they began to stink, the Aura vulture invariably came and took them off. I have frequently observed, that the day after the planter liad burnt the trash in a cane-field, the aura vulture was sure to be there, feeding on the snakes, lizards, and frogs which had suffered in the conflagration. I often saw a large bird (very much like the common gregarious vulture at a distance) catch and devour lizards; after shooting one, it turned out to be not a vulture, but a hawk, with a tail squarer and shorter than hawks have in general. The vultures, like the goatsucker and woodpecker, 
seems to be in disgrace with man. They are generally termed a voracious, stinking, cruel, and ignoble tribe. Under these impressions, the fowler discharges his gun at them, and probably thinks he has done well in ridding the earth of such vermin.

Some governments impose a fine on him who kills a vulture. This is a salutary law, and it were to be wished that other governments would follow so good an example. I would fain here say a word or two in favour of this valuable scavenger.

Kind Providence has conferred a blessing on hot countries in giving them the vulture; he has ordered it to consume that which, if left to dissolve in putrefaction, would infect the air, and produce a pestilence. When full of food, the vulture certainly appears an indolent bird; he will stand for hours together on the branch of a tree, or on the top of a house, with his wings drooping, and, after rain, with them spread and elevated to catch the rays of the sun. It has been remarked by naturalists, that the flight of this bird is laborious. I have paid attention to the vulture in Andalusia, and to those in Guiana, Brazil, and the West Indies, and conclude that they are birds of long, even, and lofty flight. Indeed, whoever has observed the aura vulture, will be satisfied that his flight is wonderfully majestic, and of long continuance.

The bird is above five feet from wing to wing extended. You will see it soaring aloft in the aërial expanse on pinions which never flutter, and which at the same time carry him through the fields of ether with a rapidity equal to that of the 


\section{WANDERINGS IN SOUTH AMERICA}

golden eagle. In Paramaribo the laws protect the vulture, and the Spaniards of Angustura never think of molesting him. In 1808, I saw the vultures in that city as tame as domestic forls; a person who had never seen a vulture would have taken them for turkeys. They are very useful to the Spaniards; and had it not been for them, the refuse of the slaughter-houses in Angustura would have caused an intolerable nuisance.

The common black, short, square-tailed vulture is gregarious; but the aura vulture is not so; for, though you may see fifteen or twenty of them feeding on the dead vermin in a cane-field, after the trash has been set fire to, still, if you have paid attention to their arrival, you will have observed that they came singly and retired singly, and thus their being all together in the same field was merely accidental, and caused by each one smelling the effluvia as he was soaring through the sky to look out for food. I have watched twenty come into a cane-field; they arrived one by one, and from different parts of the heavens. Hence we may conclude, that though the other species of vulture are gregarious, the aura vulture is not.

If you dissect a vulture that has just been feeding on carrion, you must expect that your olfactory nerves will be somewhat offended with the rank effluvia from his craw; just as they would be were you to dissect a citizen after the Lord Mayor's dinner. If, on the contrary, the vulture be empty at the time you commence the opera- 
tion, there will be no offensive smell, but a strong scent of musk.

I had long wished to examine the native haunts of the Cayman; but as the river Demerara did not afford a specimen of the large kind, I was obliged to go to the river Essequibo to look for one.

I got the canoe ready, and went down in it to George-town; where, having put in the necessary articles for the expedition, not forgetting a couple of large shark-hooks, with chains attached to them, and a coil of strong new rope, I hoisted a little sail, which I had got made on purpose, and at six o'clock in the morning shaped our course for the river Essequibo. I had put a pair of shoes on to prevent the tar at the bottom of the canoe from sticking to my feet. The sun was flaming hot, and from eleven o'clock till two beat perpendicularly upon the top of my feet, betwixt the shoes and the trousers. Not feeling it disagreeable, or being in the least aware of painful consequences, as I had been barefoot for months, I neglected to put on a pair of short stockings which I had with me. I did not reflect, that sitting still in one place, with your feet exposed to the sun, was very different from being exposed to the sun while in motion.

We went ashore in the Essequibo, about three o'clock in the afternoon, to choose a place for the night's residence, to collect firewood, and to set the fish-hooks. It was then that I first began to find my legs very painful: they soon became much inflamed and red and blistered; and it required considerable caution not to burst the blisters, 


\section{WANDERINGS IN SOUTH AMERICA}

otherwise sores would have ensued. I immediately got into the hammock, and there passed a painful and sleepless night, and for two days after I was disabled from walking.

About midnight, as I was lying awake, and in great pain, I heard the Indian say, "Massa, massa, you no hear tiger?" I listened attentively, and heard the softly sounding tread of his feet as he approached us. The moon had gone down; but every now and then we could get a glance of him by the light of our fire: he was the jaguar, for I could see the spots on his body. Had I wished to have fired at him, I was not able to take a sure aim, for I was in such pain that I could not turn myself in my hammock. The Indian would have fired, but I would not allow him to do so, as I wanted to see a little more of our new visitor; for it is not every day or night that the traveller is favoured with an undisturbed sight of the juguar in his own forests.

Whenever the fire got low, the jaguar came a little nearer, and when the Indian renewed it, he retired abruptly; sometimes he would come within twenty yards, and then we had a view of him, sitting on his hind legs like a dog; sometimes he moved slowly to and fro, and at other times we could hear him mend his pace, as if impatient. At last the Indian, not relishing the idea of having such company in the neighbourhood, could contain himself no longer, and set up a most tremendous yell. The jaguar bounded off like a racehorse, and returned no more; it appeared by the print of his feet the next morning that he was a full-grown jaguar. 
In two days after this we got to the first falls in the Essequibo. There was a superb barrier of rocks quite across the river. In the rainy season these rocks are for the most part under water; but it being now dry weather, we had a fine view of them, while the water from the river above them rushed through the different openings in majestic grandeur. Here, on a little hill, jutting out into the river, stands the house of Mrs. Peterson, the last house of people of colour up this river; I hired a negro from her, and a coloured man, who pretended that they knew the haunts of the cayman, and understood everything about taking him. We were a day in passing these falls and rapids, celebrated for the Pacou, the richest and most delicious fish in Guiana. The coloured man was now in his element; he stood in the head of the canoe, and with his bow and arrow shot the pacou as they were swimming in the stream. The arrow had scarcely left the bow before he had plunged headlong into the river, and seized the fish as it was struggling with it. He dived and swam like an otter, and rarely missed the fish he aimed at.

Did my pen, gentle reader, possess descriptive powers, I would here give thee an idea of the enchanting scenery of the Essequibo; but that not being the case, thou must be contented with a moderate and well-intended attempt.

Nothing could be more lovely than the appearance of the forest on each side of this noble river. Hills rose on hills in fine gradation, all covered with trees of gigantic height and size. Here their leaves were of a lively purple, and there of the 


\section{WANDERINGS IN SOU'TH AMERICA}

deepest green. Sometimes the Caracara extended its scarlet blossoms from branch to branch, and gave the tree the appearance as though it had been hung with garlands.

This delightful scenery of the Essequibo made the soul overflow with joy, and caused you to rove in fancy through fairy-land; till, on turning an angle in the river, you were recalled to more sober reflections on seeing the once grand and towering mora, now dead and ragged in its topmost branches, while its aged trunk, undermined by the rushing torrent, hung as though in sorrow over the river, which, ere long, would receive it, and sweep it away forever.

During the day, the trade-wind blew a gentle and refreshing breeze, which died away as the night set in, and then the river was as smooth as glass.

The moon was within three days of being full, so that we did not regret the loss of the sun, which set in all its splendour. Scarce had he sunk behind the western hills, when the Goatsuckers sent forth their soft and plaintive cries; some often repeating, "Who are you-who, who, who are you?" and others, "Willy, Willy, Willy come go."

The Indian and Daddy Quashi often shook their heads at this, and said they were bringing talk from Yabahou, who is the evil spirit of the Essequibo. It was delightful to sit on the branch of a fallen tree, near the water's edge, and listen to these harmless birds as they repeated their evening song; and watch the owls and vampires as they every now and then passed up and down the river. 
The next day, about noon, as we were proceeding onwards, we heard the Campanero tolling in the depth of the forest. Though I should not then have stopped to dissect even a rare bird, having a greater object in view, still I could not resist the opportunity offered of acquiring the campanero. The place where he was tolling was low and swampy, and my legs not having quite recovered from the effects of the sun, I sent the Indian to shoot the campanero. He got up to the tree, which he described as very high, with a naked top, and situated in a swamp. He fired at the bird, but either missed it, or did not wound it sufficiently to bring it down. This was the only opportunity I had of getting a campanero during this expedition. We had never heard one toll before this morning, and never heard one after. 


\section{CHAPTER IV}

About an hour before sunset, we reached the place which the two men who had joined us at the falls pointed out as a proper one to find a Cayman. There was a large ereek close by, and a sand-bank gently sloping to the water. Just within the forest on this bank, we cleared a place of brushwood, suspended the hammocks from the trees, and then picked up enough of decayed wood for fuel.

The Indian found a large land tortoise, and this, with plenty of fresh fish which we had in the canoe, afforded a supper not to be despised.

The tigers had kept up a continued roaring every night since we had entered the Essequibo. The sound was awfully fine. Sometimes it was in the immediate neighbourhood; at other times it was far off, and echoed amongst the hills like distant thunder.

It may, perhaps, not be amiss to observe here, that when the word tiger is used, it does not mean the Bengal tiger. It means the jaguar, whose skin is beautifully spotted, and not striped like that of the tiger in the East. It is, in fact, the tiger of the new world, and receiving the name of tiger from the discoverers of South America, it has kept it ever since. It is a cruel, strong, and dangerous beast, but not so courageous as the Bengal tiger. 


\section{WANDERINGS IN SOU'TH AMERICA 233}

We now baited a shark-hook with a large fish, and put it upon a board about a yard long, and one foot broad, which we had brought on purpose. This board was carried out in the canoe, about forty yards into the river. By means of a string, long enough to reach the bottom of the river, and at the end of which string was fastened a stone, the board was kept, as it were, at anchor. One end of the new rope I had bought in town was reeved through the chain of the shark-hook, and the other end fastened to a tree on the sand-bank.

It was now an hour after sunset. The sky was cloudless, and the moon shone beautifully bright. There was not a breath of wind in the heavens, and the river seemed like a large plain of quicksilver. Every now and then a huge fish would strike and plunge in the water; then the owls and goatsuckers would continue their lamentations, and the sound of these was lost in the prowling tiger's growl. Then all was still again, and silent as midnight.

The caymen were now upon the stir, and at intervals their noise could be distinguished amid that of the jaguar, the owls, the goatsuckers, and frogs. It was a singular and awful sound. It was like a suppressed sigh, bursting forth all of a sudden, and so loud that you might hear it above a mile off. First one emitted this horrible noise, and then another answered him; and on looking at the countenances of the people around me, I could plainly see that they expected to have a cayman that night.

We were at supper, when the Indian, who seemed to have had one eye on the turtle-pot and 


\section{WANDERINGS IN SOUTH AMERICA}

the other on the bait in the river, said he saw the cayman coming.

Upon looking towards the place, there appeared something on the water like a black log of wood. It was so unlike anything alive, that I doubted if it were a cayman; but the Indian smiled, and said he was sure it was one, for he remembered seeing a cayman, some years ago, when he was in the Essequibo.

At last it gradually approached the bait, and the board began to move. The moon shone so bright that we could distinctly see him open his huge jaws, and take in the bait. We pulled the rope. He immediately let drop the bait; and then we saw his black head retreating from the board, to the distance of a few yards, and there it remained quite motionless.

$\mathrm{He}$ did not seem inclined to advance again; and so we finished our supper. In about an hour's time he again put himself in motion, and took hold of the bait. But, probably, suspecting that he had to deal with knaves and cheats, he held it in his mouth but did not swallow it. We pulled the rope again, but with no better success than the first time.

He retreated as ustual, and came back again in about an hour. We paid him every attention till three o'clock in the morning; when, worn out with disappointment, we went to the hammocks, turned in, and fell asleep.

When day broke, we found that he had contrived to get the bait from the hook, though we had tied it on with string. We had now no more hopes of taking a cayman till the return of night. 
The Indian took off into the roods, and brought back a noble supply of game. The rest of us went into the canoe, and proceeded up the river to shoot fish. We got even more than we could use.

As we approachd the shallows, we could see the large Sting-rays moving at the bottom. The coloured man never failed to hit them with his arrow. The weather was delightful. There was scarcely a cloud to intercept the sun's rays.

I saw several scarlet aras, anihingas, and ducks, but could not get a shot at them. The parrots crossed the river in innumerable quantities, always flying in pairs. Here, too, I saw the Sun-bird, called Tirana by the Spaniards in the Oroonoque, and shot one of them. The black and white Scarlet-headed Finch was very common here. I could never see this bird in the Demerara, nor hear of its being there.

We at last came to a large sand-bank, probably two miles in circumference. As we approached it we could see two or three hundred Fresh-water Turtle on the edge of the bank. Ere we could get near enough to let fly an arrow at them, they had all sunk into the river and appeared no more.

We went on the sand-bank to look for their nests, as this was the breeding season. The coloured man showed us how to find them. Wherever a portion of the sand seemed smoother than the rest, there was sure to be a turtle's nest. On digging down with our hands, about nine inches deep, we found from twenty to thirty white eggs; in less than an hour we got about two hundred. Those which had a little black spot or two on the shell we ate the same day, as it was a sign 


\section{WANDERINGS IN SOUTH AMERICA}

that they were not fresh, and of comrse would not keep: those which had no speck were put into dry sand, and were good some weeks after.

At midnight, two of our people went to this sand-bank, while the rest stayed to watch the cayman. The turtle had advanced on to the sand to lay their eggs, and the men got betwixt them and the water; they brought off half a dozen very fine and well-fed turtle. The egg-shell of the fresh-water turtle is not hard like that of the land tortoise, but appears like white parchment and gives way to the pressure of the fingers; but it is very tongh, and does not break. On this sandbank, close to the forest, we found several Guana's nests; but they had never more than fourteen eggs a-piece. Thus passed the day in exercise and knowledge, till the sun's declining orb reminded us it was time to return to the place from whence we had set out.

The second night's attempt upon the cayman was a repetition of the first, quite unsuccessful. We went a fishing the day after, had excellent sport, and returned to experience a third night's disappointment. On the fourth evening, about four o'clock, we began to erect a stage amongst the trees, close to the water's edge. From this we intended to shoot an arrow into the cayman: at the end of this arrow was to be attached a string, which would be tied to the rope, and as soon as the cayman was struck we were to have the canoe ready and pursue him in the river.

While we were busy in preparing the stage, a tiger began to roar. We judged by the sound that he was not above a quarter of a mile from 


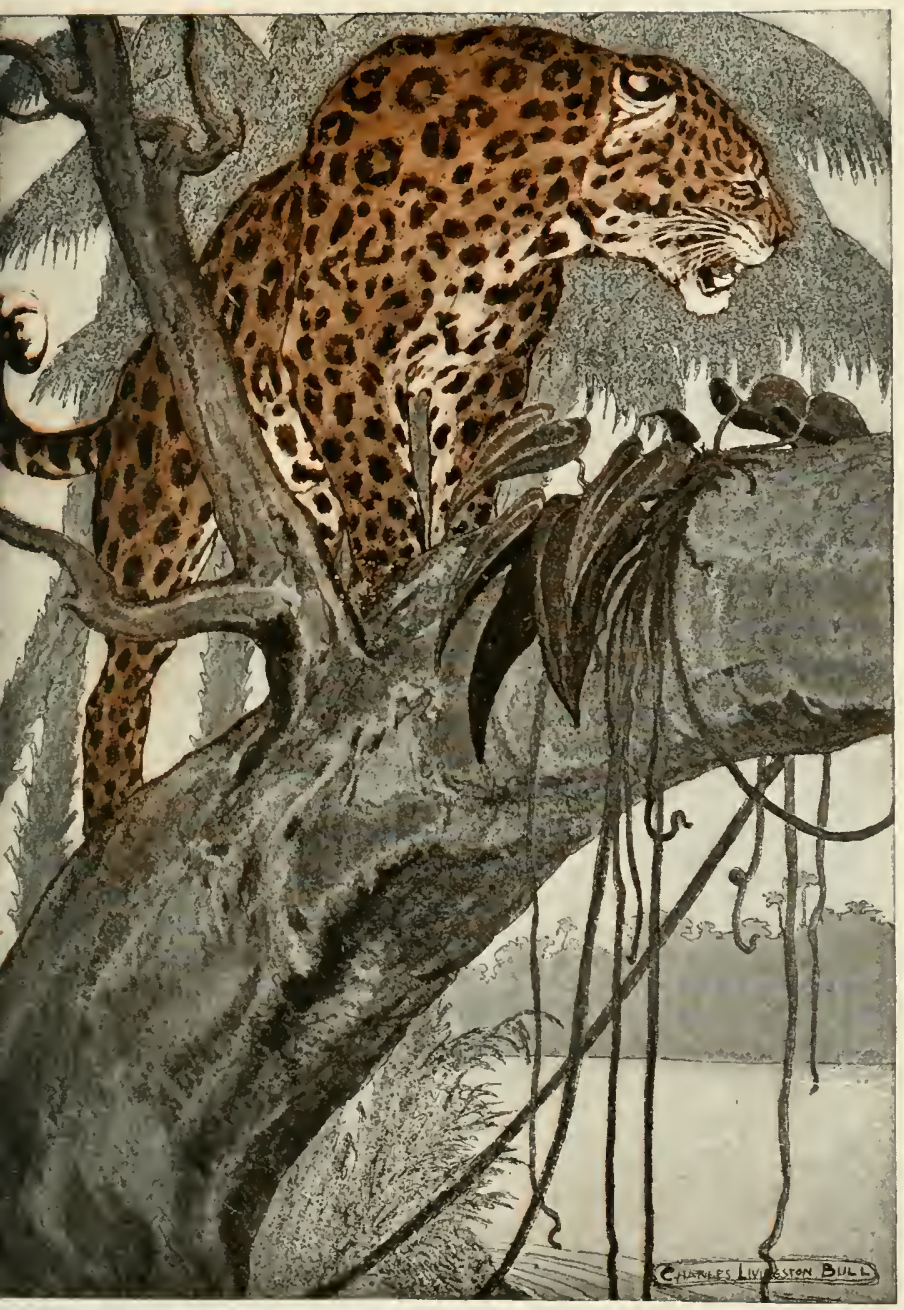

"An immense Jaguar, standing on the trunk of an aged Mora-tree", 

us, and that he was close to the side of the river. Unfortunately, the Indian said it was not a jaguar that was roaring, but a conguar. The couguar is of a pale, brownish red colour, and not as large as the jaguar. As there was nothing particular in this animal, I thought it better to attend to the apparatus for catching the cayman than to go in quest of the couguar. The people, however, went in the canoe to the place where the couguar was roaring. On arriving near the spot, they saw it was not a couguar, but an immense jaguar, standing on the trunk of an aged mora-tree, which bended over the river; he growled and showed his teeth as they approached; the coloured man fired at him with a ball, but probably missed him, and the tiger instantly descended, and took off into the woods. I went to the place before dark, and we searched the forest for about half a mile in the direction he had fled, but we could see no traces of him, or any marks of blood; so I concluded that fear had prevented the man from taking steady aim.

We spent best part of the fourth night in trying for the cayman, but all to no purpose. I was now convinced that something was materially wrong. We ought to have been successful, considering our vigilance and attention, and that we had repeatedly seen the cayman. It was useless to tarry here any longer; moreover, the coloured man began to take airs, and fancied that I could not do without him. I never admit of this in any expedition where I am commander; and so I convinced the man, to his sorrow, that $I$ could do without him; for I paid him what I had agreed 
to give him, which amounted to eight dollars, and ordered him back in his own curial to Mrs. Peterson's, on the hill at the first falls. I then asked the negro if there were any Indian settlements in the neighbourhood; he said he knew of one, a day and a half off. We went in quest of it, and about one o'clock the next day the negro showed us the creek where it was.

The entrance was so concealed by thick bushes that a stranger would have passed it without knowing it to be a creek. In going up it we found it dark, winding, and intricate beyond any creek that I had ever seen before. When Orpheus came back with his young wife from Styx, his path must have been similar to this, for Ovid says it was

$$
\text { "Arduus, obliquus, caligine densus opaca," }
$$

and this creek was exactly so.

When we had got about two-thirds up it, we met the Indians going a fishing. I saw, by the way their things were packed in the curial, that they did not intend to return for some days. However, on telling them what we wanted, and by promising handsome presents of powder, shot, and hooks, they dropped their expedition, and invited us np to the settlement they had just left, and where we laid in a provision of cassava.

They gave us for dinner boiled ant-bear and red monkey; two dishes unknown even at Beauvilliers in Paris, or at a London city feast. The monkey was very good indeed, but the ant-bear had been kept beyond its time; it stunk, as our venison does in England; and so, after tasting it, 
I preferred dining entirely on monkey. After resting here, we went back to the river. The Indians, three in number, accompanied us in their own curial, and, on entering the river, pointed to a place a little way above, well calculated to harbour a cayman. The water was deep and still, and flanked by an immense sand-bank; there was also a little shallow creek close by.

On this sand-bank, near the forest, the people made a shelter for the night. My own was already made; for I always take with me a painted sheet, about twelve feet by ten. This, thrown over a pole, supported betwixt two trees, makes you a capita! roof with very little trouble.

We showed one of the Indians the shark-hook. He shook his head and laughed at it, and said it would not do. When he was a boy, he had seen his father catch the caymen, and on the morrow he would make something that would answer.

In the meantime, we set the shark-hook, but it availed us nought; a cayman came and took it, but would not swallow it.

Seeing it was useless to attend the shark-hook any longer, we left it for the night, and returned to our hammocks.

Ere I fell asleep, a reflection or two broke in upon me. I considered, that as far as the judgment of civilized man went, everything had been procured and done to ensure success. We had hooks, and lines, and baits, and patience; we had spent nights in watching, had seen the cayman come and take the bait, and after our expectations had been wound up to the highest pitch, all ended in disappointment. Probably this poor 
wild man of the roods would succeed by means of a very simple process; and thus prove to his more civilized brother that, notwithstanding books and schools, there is a vast deal of knowledge to be picked up at every step, whichever way we turn ourselves.

In the morning, as usual, we found the bait gone from the shark-hook. The Indians went into the forest to hunt, and we took the canoe to shoot fish and get another supply of turtle's eggs, which we found in great abundance on this large sand-bank.

We went to the little shallow creek, and shot some young caymen, about two feet long. It was astonishing to see what spite and rage these little things showed when the arrow struck them; they turned round and bit it, and snapped at us when we went into the water to take them up. Daddy Quashi boiled one of them for his dinner, and found it very sweet and tender. I do not see why it should not be as good as frog or veal.

The day was now declining apace, and the Indian had made his instrument to take the cayman. It was very simple. There were four pieces of tough hard wood, a foot long, and about as thick as your little finger, and barbed at both ends; they were tied round the end of the rope, in such a manner, that if you conceive the rope to be an arrow, these four sticks would form the arrow's head; so that one end of the four united sticks answered to the point of the arrow-head, while the other ends of the sticks expanded at equal distances round the rope. Now it is evident, that if the cayman swallowed this (the other end of 


\section{WANDERINGS IN SOUTH AMERICA 241}

the rope, which was thirty yards long, being fastened to a tree), the more he pulled, the faster the barbs would stick into his stomach. This wooden hook, if you may so call it, was well baited with the flesl of the acouri, and the entrails were twisted round the rope for about a foot above it.

Nearly a mile from where we had our hammocks, the sand-bank was steep and abrupt, and the river very still and deep; there the Indian pricked a stick into the sand. It was two feet long, and on its extremity was fixed the machine; it hung suspended about a foot from the water, and the end of the rope was made fast to a stake driven well into the sand.

The Indian then took the empty shell of a land tortoise and gave it some heavy blows with an axe. I asked him why he did that. He said it was to let the cayman hear that something was going on. In fact the Indian meant it as the cayman's dinner-bell.

Having done this, we went back to the hammocks, not intending to visit it again till morning. During the night, the jaguars roared and grumbled in the forest, as though the world was going wrong with them, and at intervals we could hear the distant cayman. The roaring of the jaguars was awful; but it was music to the dismal noise of these hideous and malicious reptiles.

About half-past five in the morning, the Indian stole off silently to take a look at the bait. On arriving at the place he set up a tremendous shout. We all jumped out of our hammocks, and ran to him. The Indians got there before me, for they had no clothes to put on, and I lost two 


\section{WANDERINGS IN SOUTH AMERICA}

minutes in looking for my trousers and in slipping into them.

We found a cayman, ten feet and a half long, fast to the end of the rope. Nothing now remained to do, but to get him out of the water without injuring his scales, "hoc opus, hic labor." We mustered strong: there were three Indians from the creek, there was my own Indian Yan, Daddy Quashi, the negro from Mrs. Peterson's, James, Mr. R. Edmonstone's man, whom I was instructing to preserve birds, and lastly, myself.

I informed the Indians that it was my intention to draw him quietly out of the water, and then secure him. They looked and stared at each other, and said I might do it myself; but they would have no hand in it; the cayman would worry some of us. On saying this, "consedere duces," they squatted on their hams with the most perfect indifference.

The Indians of these wilds have never been subject to the least restraint; and I knew enough of them to be aware, that if I tried to force them against their will, they would take off, and leave me and my presents unheeded and never return.

Daddy Quashi was for applying to our guns, as usual, considering them our best and safest friends. I immediately offered to knock him down for his cowardice, and he shrunk back, begging that I would be cantious, and not get myself worried; and apologizing for his own want of resolution. My Indian was now in conversation with the others, and they asked if I would allow them to shoot a dozen arrows into him, and thus disable him. This would have ruined all. I had 
come abore three hundred miles on purpose to get a cayman uninjurer, and not to carry back a mutilated specimen. I rejected their proposition with firmmess, and darted a disclainful eye upon the Indians.

Daddy Quashi was again beginning to remonstrate, and I chased him on the sand-bank for a quarter of a mile. He told me afterwards, he thought he should have dropped domn dead with fright, for he was firmly persuaded, if I had caught him, I should have bundled him into the cayman's jaws. Hele then Te stood, in silence, like a calm hefore a inminci-storm. "Hoc res summa loco. Scinditur in contraria vulgus." They wanted to kill liim, and I wanted to take him alive.

I now malked up and down the sand, revolving a dozen projects in my head. The canoe was at a considerable distance, and I ordered the people to bring it round to the place where we were. The mast was eight feet long, and not much thicker than my wrist. I took it out of the canoe, and wrapped the sail round the end of it. Now it appeared clear to me that if I went down upon one knee, and held the mast in the same position as the soldier holds his bayonet when rushing to the charge, I could force it down the cayman's throat, should he come open-mouthed at me. When this was told to the Indians, they hrojhtened up, and said they rould help me to pril him out of the river.

"Brave squad!" said I to myself, " "Audax omnia perpeti," now that you have got me betwixt yourselves and danger." I then mustered all 


\section{WANDERINGS IN SOU'TH AMERICA}

liands for the last time before the battle. We were, four South American savages, two negroes from Africa, a creole from 'Trinidad, and myself a white man from Yorkshire. In fact, a little tower of Babel group, in dress, no dress, address, and language.

Daddy Quashi hung in the rear; I showed him a large Spanish knife, which $I$ always carried in the waistband of my trousers: it spoke volumes to him, and he shrugged up his shoulders in absolute despair. The sun was just peeping over the high forests on the eastern hills, as if coming to look on, and bid us act with becoming fortitude. I placed all the people at the end of the rope, and ordered them to pull till the cayman appeared on the surface of the water; and then, should he plunge, to slacken the rope and let him go again into the deep.

I now took the mast of the canoe in my hand (the sail being tied round the end of the mast) and sunk down upon one knee, about four yards from the water's edge, determining to thrust it down his throat, in case he gave me an opportunity. I certainly felt somewhat uncomfortable in this situation, and I thought of Cerberus on the other side of the Styx ferry. The people pulled the cayman to the surface; he plunged furiously as soon as he arrived in these upper regions, and immediately went below again on their slackening the rope. I saw enough not to fall in love at first sight. I now told them we would run all risks, and have him on land immediately. They pulled again, and out he came,-_"monstrum horrendum, informe." This was an interesting mo- 


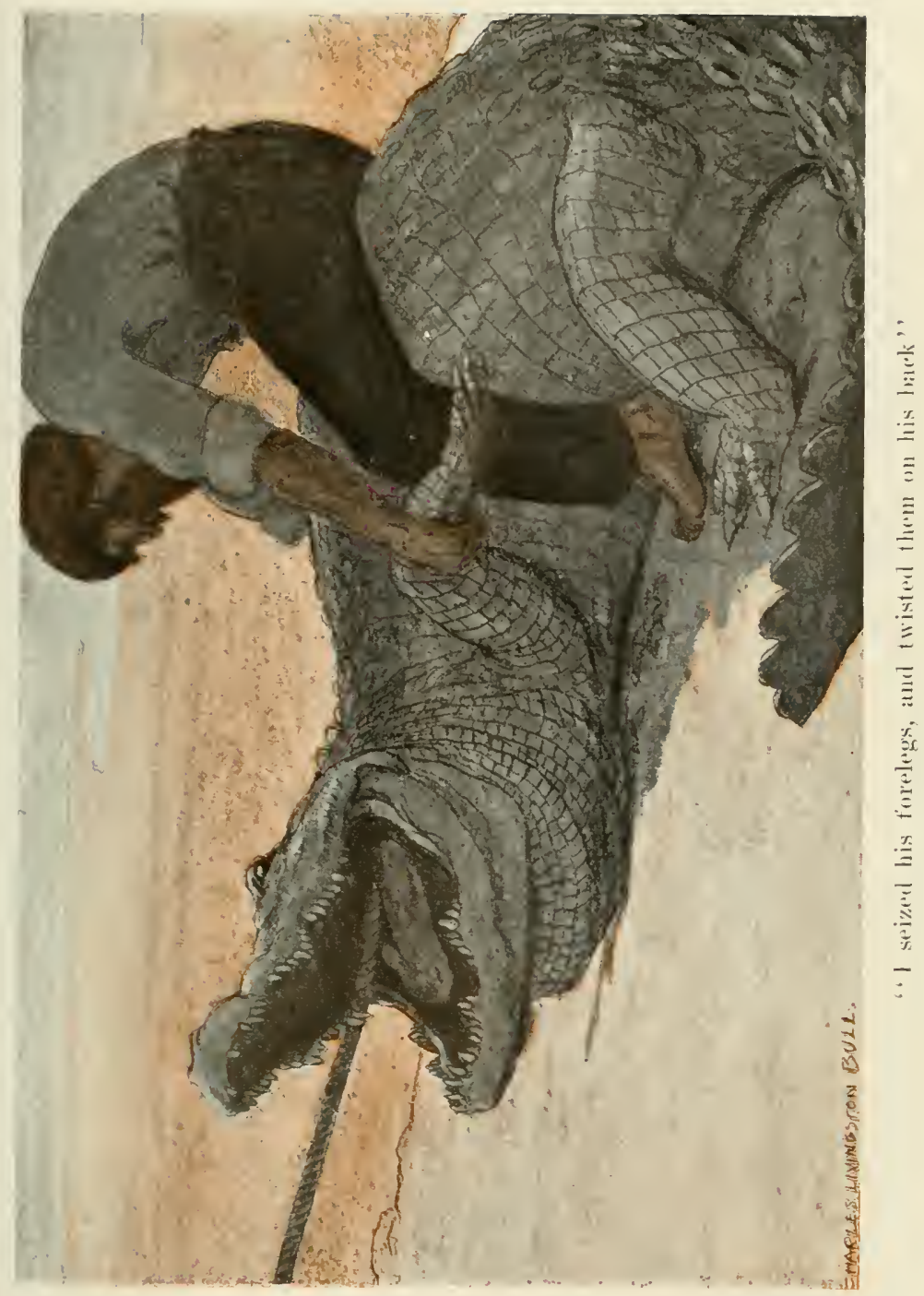



ment. I kept my position firmly, with my eye fixed steadfast on him.

By this time the cayman was within two yards of me. I saw he was in a state of fear and perturbation; I instantly dropped the mast, sprang up, and jumped on his back, turning half round as I vaulted, so that I gained my seat with my face in a right position. I immediately seized his forelegs, and, by main force, twisted them on his back; thus they served me for a bridle.

He now seemed to have recovered from his surprise, and probably fancying himself in hostile company, he began to plunge furiously, and lashed the sand with his long and powerful tail. I was out of reach of the strokes of it, by being near his head. He continued to plunge and strike, and made my seat very uncomfortable. It must have been a fine sight for an unoccupied spectator.

The people roared out in triumph, and were so vociferous, that it was some time before they heard me tell them to pull me and my beast of burden farther inland. I was apprehensive the rope might break, and then there would have been every chance of going down to the regions under water with the cayman. That would have been more perilous than Arion's marine morning ride :-

"Delphini insidens vada cærula sulcat Arion."

The people now dragged us above forty yards on the sand: it was the first and last time I was ever on a cayman's back. Should it be asked, how I managed to keep my seat, I would answer, 


\section{WANDERINGS IN SOUTH AMERICA}

-I hunted some rears with Lord Darlington's fox-hounds.

After repeated attempts to regain his liberty, the cayman gave in, and became trancuil through exhaustion. I now managed to tie up his jaws, and firmly secured his fore-feet in the position I had held them. We had now another severe struggle for superiority, but he was soon orercome and again remained quiet. While some of the people were pressing upon his head and shoulders, I threw myself on his tail, and by keeping it down to the sand, prevented him from kicking up another dust. He was finally conveyed to the canoe, and then to the place where we had suspended our hammocks. There I cut his throat; and, after' breakfast was over, commenced the dissection.

Now that the affray had ceased, Daddy Quashi played a good finger and thumb at breakfast; he said he found himself much revived, and became very talkative and useful, as there was no longer any danger. He was a faithful, honest negro. His master, my worthy friend Mr. Edmonstone, had been so obliging as to send out particular orders to the colony, that the Daddy should attend me all the time I was in the forest. He had lived in the wilds of Demerara with Mr. Edmonstone for many years; and often amused me with the account of the frays his master had had in the woods with snakes, wild beasts, and runaway negroes. Old age was now coming fast upon him; he had been an able fellow in his younger dars, and a gallant one too, for he had a large scar orel his eychrow, caused by the stroke of a cut- 
lass, from another negro, while the Daddy was engaged in an intrigue.

The back of the cayman may be said to be almost impenetrable to a musket-ball, but his sides are not near so strong, and are easily pierced with an arrow; indeed, were they as strong as the back and the belly, there would be no part of the cayman's body soft and elastic enough to admit of expansion after taking in a supply of food.

The cayman has no grinders; his teeth are entirely made for suatch and swallow; there are thirty-two in each jaw. Perhaps no animal in existence bears more decided marks in his countenance of cruelty and malice than the cayman. $\mathrm{He}$ is the scourge and terror of all the large rivers in South America near the line.

One Sunday evening, some years ago, as I was walking with Don Felipe de Ynciarte, governor of Angustura, on the bank of the Oroonoque, "Stop here a minute or two, Don Carlos," said he to me, "while I recount a sad accident. One fine evening last year, as the people of Angustura were sauntering up and down here, in the Alameda, I was within twenty yards of this place, when I saw a large cayman rush out of the river, seize a man, and carry him down, before anybody had it in his power to assist him. The screams of the poor fellow were terrible as the cayman was running off with him. He plunged into the river with his prey; we instantly lost sight of him, and never saw or heard him more."

I was a day and a half in dissecting our cayman, and then we all got ready to return to Demerara. 
It was much more perilous to descend than to ascend the falls in the Essequibo.

The place we had to pass had proved fatal to four Indians about a month before. The water foamed, and dashed and boiled, amongst the steep and craggy rocks, and seemed to warn us to be careful how we ventured there.

I was for all hands to get out of the canoe, and then after lashing a long rope ahead and astern, we might have climbed from rock to rock, and tempered her in her passage down, and our getting out would have lightened her much. But the negro who had joined us at Mrs. Peterson's said he was sure it would be safer to stay in the canoe while she went down the fall. I was loath to give way to him; but I did so this time against my better judgment, as he assured me that he was accustomed to pass and repass these falls.

Accordingly we determined to push down: I was at the helm, the rest at their paddles. But before we got half way through, the rushing waters deprived the canoe of all power of steerage, and she became the sport of the torrent; in a second she was half full of water, and I cannot comprehend to this day why she did not go down; luckily the people exerted themselves to the utmost,- she got headway, and they pulled through the whirlpool; I being quite in the stern of the canoe, part of a wave struck me, and nearly knocked me overboard.

We now paddled to some rocks at a distance, got out, unloaded the canoe, and dried the cargo in the sun, which was very hot and powerful. Had 


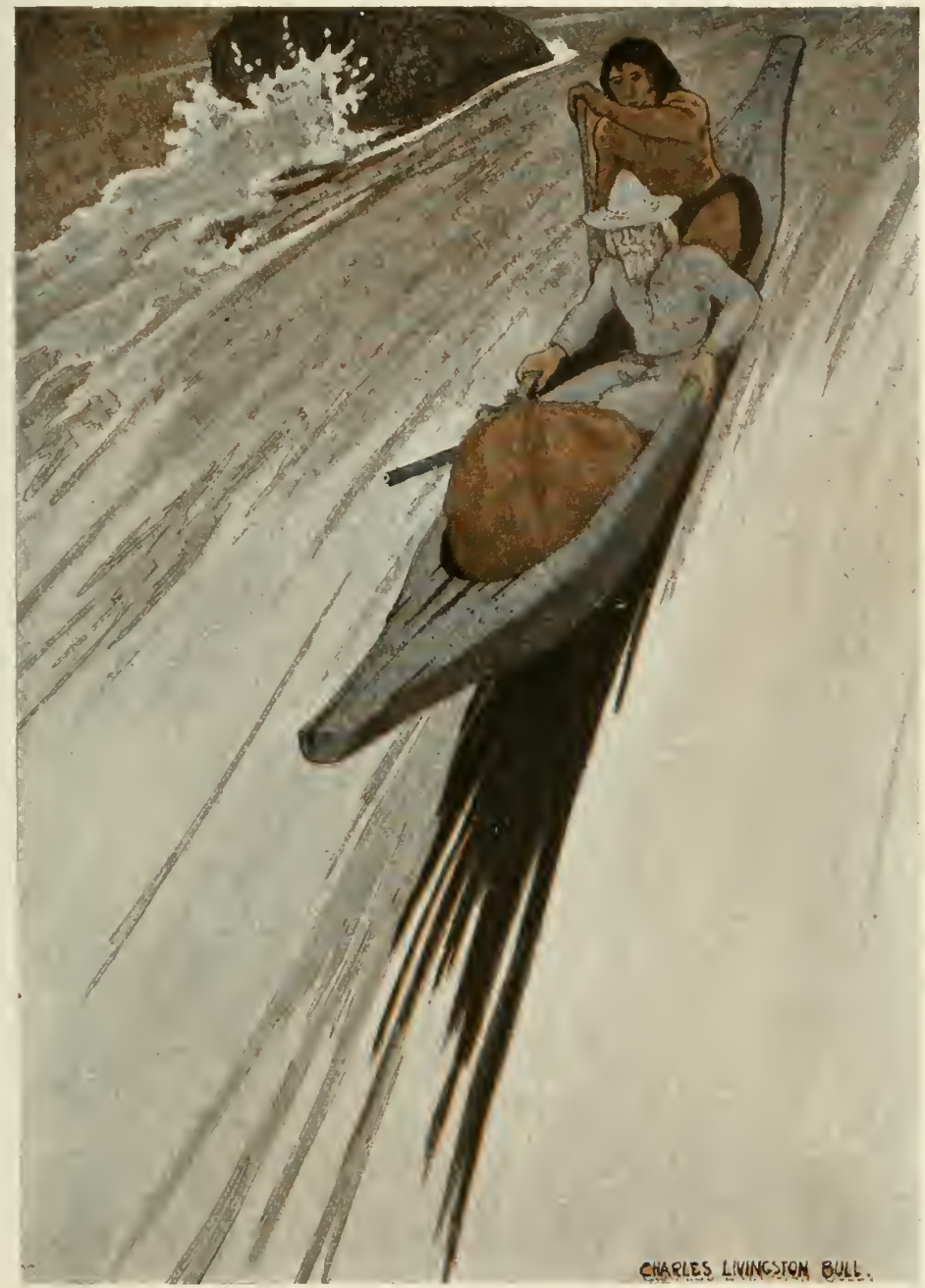

"The water foamerl, and rlasherl, and boiler, amongst the rocks", 

it been the wet season, almost everything would have been spoiled.

After this, the voyage down the Essequibo was quick and pleasant till we reached the sea-coast; there we had a trying day of it; the wind was dead against us, and the sun remarkably hot; we got twiee aground upon a mud-flat, and were twice obliged to get out, up to the middle in mud, to shove the canoe through it. Half way betwixt the Essequibo and Demerara the tide of flood caught us; and after the utmost exertions, it was half-past six in the evening before we got to George-town.

We had been out from six in the morning in an open canoe on the sea-coast, without umbrella or awning, exposed all day to the fiery rays of a tropical sun. My face smarted so that I could get no sleep during the night, and the next morning my lips were all in blisters. The Indian Yan went down to the Essequibo a copper colour, but the reflection of the sun from the sea, and from the sand-banks in the river, had turned him nearly black. He laughed at himself, and said that the Indians in the Demerara would not know him again. I stayed one day in George-town, and then set off the next morning for head-quarters in Mibiri creek, where I finished the cayman.

Here the remaining time was spent in collecting birds, and in paying particular attention to their haunts and economy. The rainy season having set in, the weather became bad and stormy; the lightning and thunder were incessant: the days cloudy, and the nights cold and misty. I had now been eleven months in the 


\section{IVANDERINGS IN SOUTH AMERICA}

forests, and collected some rare insects, two hundred and thirty birds, two land tortoises, ine armadillos, two large serpents, a sloth, an ant-bear, and a cayman.

I left the wilds and repaired to George-town to spend a few days with Mr. R. Edmonstone previous to embarking for Europe. I must here return my sincerest thanks to this worthy gentleman for his many kindnesses to me; his friendship was of the utmost service to me, and he never failed to send me supplies up into the forest by every opportunity.

I embarked for Fngland, on board the Dee West-Indiaman, commanded by Captain Grey.

Sir Joseph Banks had often told me, he hoped that I would give a lecture in public, on the new mode I had discovered of preparing specimens in natural history for museums. I always declined to do so, as I despaired of ever being able to hit upon a proper method of doing quadrupeds; and I was aware that it would liave been an imperfect lecture to treat of birds only. I imparted what little knowledge I was master of, at Sir Joseph's, to the unfortunate gentlemen who went to Africa to explore the Congo; and that was all that took place in the shape of a lecture. Now that I had hit upon the way of doing quadrupeds, I drew up a little plan on board the Dee, which I trusted would have been of service to naturalists; and hy proving to them the superiority of the new plan, they would probably be induced to abandon the old and common way, which is a disgrace to the present age, and renders hideous every specimen in every museum that I have as yet visited. 
I intended to have given three lectures; one on insects and serpents; one on birds; and one on quadrupeds. But, as it will be shortly seen, this little plan was doomed not to be unfolded to public view. Illiberality blasted it in the bud.

We had a pleasant passage across the Atlantic, and arrived in the Mersey in fine trim and good spirits. Great was the attention I received from the commander of the Dee. Me and his mate, Mr. Spence, took every care of my collection.

On our landing, the gentlemen of the Liverpool Custom-house received me as an old friend and aequaintance, and obligingly offered their services.

Twice before had I landed in Liverpool, and trice had I reason to admire their conduct and liberality. They knew I was incapable of trying to introduce anything contraband, and they were aware that I never dreamed of turning to profit the specimens I had procured. They considered that I had left a comfortable home in quest of science; and that I had wandered into far-distant climes, and gone barefooted, ill-clothed, and illfed, through swamps and woods, to procure specimens, some of which had never been seen in Europe. They considered that it would be difficult to fix a price upon specimens which had never been hought or sold, and which never were to be, as they were intended to ornament my own house. It was hard, they said, to have exposed myself, for years, to danger, and then be obliged to pay on returning to my native land. Under these considerations, they fixed a moderate duty, which satisfed all parties. 
However, this last expedition ended not so. It taught me how hard it is to learn the grand lesson, "xquam memento rebus in arduis servare mentem."

But my good friends in the Custom-house of Liverpool were not to blame. On the contrary, they did all in their power to procure balm for me instead of rue. But it would not answer.

They appointed a very civil officer to attend me to the ship. While we were looking into some of the boxes, to see that the specimens were properly stowed, previous to their being conveyed to the king's depôt, another officer entered the cabin. He was an entire stranger to me, and seemed wonderfully aware of his own consequence. Withont preface or apology, he thrust his head over my shoulder, and said, we had no business to have opened a single box without his permission. I answered, they had been opened almost every day since they had come on board, and that I considered there was no harm in doing so.

He then left the cabin, and I said to myself as he went ont, "I suspect I shall see that man again at Philippi." The boxes, ten in number, were conveyed in safety from the ship to the depôt. I then proceeded to the Custom-house. The necessary forms were gone through, and a proportionate duty, according to circumstances, was paid.

This done, we returned from the Custom-house to the depôt, accompanied by several gentlemen who wished to see the collection. They expressed themselves highly gratified. The boxes were closed, and nothing now remained but to convey 
them to the cart, which was in attendance at the door of the depot. Just as one of the inferior officers was carrying a box thither, in stepped the man whom I suspected I should see again at Philippi. He abruptly declared himself dissatisfied with the valuation which the gentlemen of the Customs had put upon the collection, and said he must detain it. I remonstrated, but it was all in vain.

After this pitiful stretch of power, and bad compliment to the other officer's of the Customs, who had been satisfied with the valuation, this man had the folly to take me aside, and after assuring me that he had a great regard for the arts and sciences, he lamented that conscience obliged him to do what he had done, and he wished he had been fifty miles from Liverpool at the time that it fell to his lot to detain the collection. Had he looked in my face as he said this, he would have seen no marks of credulity there.

I now returned to the Custom-house, and after expressing my opinion of the officer's conduct at the depôt, I pulled a bunch of keys (which belonged to the detained boxes) out of my pocket, laid them on the table, took my leave of the gentlemen present, and soon after set off for Yorkshire.

I saved nothing from the grasp of the stranger officer but a pair of live Malay fowls, which a gentleman in George-town had made me a present of. I had collected in the forest several eggs of curious birds, in hopes of introducing the breed into England, and had taken great pains in doing them over with gum-arabic, and in packing them in charcoal, according to a receipt I had seen in 


\section{$25 \pm$ WANDERINGS IN SOUTI ANERIC}

the gazette, from the Edinburgh Philosophical Journal. But these were detained in the depôt, instead of being placed under a hen; which utterly ruined all my hopes of rearing a new species of hirds in England. Titled personages in London interested themselves in behalf of the collection, but all in vain. And rain also were the public and private representations of the first officer of the Liverpool Custom-house in my favour.

At last there came an order from the Treasury to say, that any specimens Mr. Waterton intended to present to public institutions might pass duty free; but those which he intended to keep for himself must pay the duty!

A friend now wrote to me from Lirerpool, requesting that I would come orer and pay the duty, in order to save the collection, which had just been detained there six weeks. I did so. On paying an additional duty (for the moderate duty first imposed had already been paid), the man who had detained the collection delivered it up to me, assuring me that it had been well taken care of, and that a fire had been frequently made in the room. It is but justice to add, that on opening the boxes, there was nothing injured.

I could never get a clue to these harsh and mexpected measures, except that there had been some recent smuggling discovered in Liverpool; and that the man in question had been sent down from London to act the part of Argus. If so, I landed in an evil hour"; "nefasto die;" making good the Spanish proverb, "Pagan a las veces, justos por pecadores;" at times the innocent suffer for the guilty. After all, a little encourage- 
ment, in the shape of exemption from paying the duty on this collection, might have been expected; but it turned out otherwise; and after expending large sums in pursuit of natural history, on my return home I was doomed to pay for my success :-

"Hic finis, Caroli fatorum, hic exitus illum,
Sorte tulit!"

Thus, my fleece, already ragged and torn with the thorns and briers, which one must naturally expect to find in distant and untrodden wilds, was shorn, I may say, on its return to England.

However, this is nothing new; Sancho Panza must have heard of similar cases; for he says, "Muchos van por lana, y vuelven trasquilados;" many go for wool, and come home shorn. In order to pick up matter for natural listory, I have wandered through the wildest parts of South America's equatorial regions. I have attacked and slain a modern Python, and rode on the back of a cayman close to the water's edge; a very different situation from that of a Hyde-park dandy on his Sunday prancer before the ladies. Alone and barefoot I have pulled poisonous snakes out of their lurking-places; climbed up trees to peep into holes for bats and vampires, and for days together hastened through sun and rain to the thickest parts of the forest to procure specimens I had never got before. In fine, I have pursued the wild beasts over hill and dale, through swamps and quagmires, now scorched by the noon-day sun, now drenched by the pelting 
shower, and returned to the hammock, to satisfy the cravings of hunger, often on a poor and scanty supper.

These vicissitudes have turned to chestnut hue a once English complexion, and changed the colour of my hair, before Father 'Time had meddled with it. The detention of the collection after it had fairly passed the Customs, and the subsequent order from the Treasury that I should pay duty for the specimens, unless they were presented to some public institution, have cast a damp upon my energy, and forced, as it were, the eup of Lethe to my lips, by drinking which $\mathrm{I}$ have forgot my former intention of giving a lecture in public on preparing specimens to adorn museums. In fine, it is this ungenerous treatment that has paralyzed my plans, and caused me to give up the idea I once had of inserting here the newlydiscovered mode of preparing quadrupeds and serpents; and without it, the account of this last expedition to the wilds of Guiana is nothing but a-fragment.

Farewell, Gentle Reader. 


\section{FOURTH .JOURNEY}

\section{CHAPTER I}

"Nune huc, nunc illuc et utrinque sine ordine curro.",

Courteous reader, when I bade thee last farewell, I thought these Wanderings were brought to a final close; afterwards I often roved in imagination through distant countries famous for natural history, but felt no strong inclination to go thither, as the last adventure had terminated in such unexpected vexation. The departure of the Cuckoo and Swallow, and summer birds of passage, for warmer regions, once so interesting to me, now scarcely caused me to turn my face to the south; and I continued in this cold and dreary climate for three years. During this period, I seldom or ever mounted my hobby-horse; indeed it may be said, with the old song-

"The saddle and bridle were laid on the shelf,"

and only taken down once, on the night that I was induced to give a lecture in the philosophical hall of Leeds. A little after this, Wilson's Ornithology of the United States fell into my hands.

The desire I had of seeing that country, together with the animated description which Wilson had given of the birds, fanned up the almost 


\section{IVANDERINGS IN SOUTH AMERICA}

expiring flame. I forgot the vexations already alluded to, and set off for New York, in the beautiful packet John Wells, commanded by Captain Harris. The passage was long and cold; but the elegant accommodations on board, and the polite attention of the commander, rendered it very agreeable; and I landed, in health and merriment, in the stately capital of the new world.

We will soon pen down a few remarks on this magnificent eity, but not just now. I want to venture into the north-west country, and get to their great canal, which the world talks so much about, though I fear it will be hard work to make one's way through bugs, bears, brutes, and buffaloes, which we Europeans imagine are so frequent and ferocious in these never-ending western wilds.

I left New York on a fine morning in July, without one letter of introduction, for the city of Albany, some hundred and eighty miles up the celebrated Hudson. I seldom care about letters of introduction, for I am one of those who depend much upon an accidental acquaintance. Full many a face do I see, as I go wandering up and down the world, whose mild eye, and sweet and placid features, seem to beckon to me, and say, as it were, "Speak but civilly to me, and I will do what I can for you." Such a face as this is worth more than a dozen letters of introduction; and such a face, gentle reader, I found on board the steam-boat from New York to the city of Albany.

There was a great number of well-dressed ladies and gentlemen in the vessel, all entire 
strangers to me. I fancied I could see several whose countenances invited an unknown wanderer to come and take a seat beside them; but there was one who encouraged me more than the rest. I saw clearly that he was an American, and I judged, by his manners and appearance, that he had not spent all his time upon his native soil. I was right in this conjecture, for he afterwards told me that he had been in France and England. I saluted him as one stranger gentleman ought to salute another when he wants a little information; and soon after, I dropped in a word or two by which he might conjecture that I was a foreigner; but I did not tell him so; I wished him to make the discovery himself.

He entered into conversation with the openness and candour which is so remarkable in the American; and in a little time observed that he presumed I was from the old country. I told him that I was, and added, that I was an entire stranger on board. I saw his eye brighten up at the prospect he had of doing a fellow-creature a kind turn or two, and he completely won my regard by an affability which I shall never forget. This obliging gentleman pointed out everything that was grand and interesting as the steam-boat plied her course up the majestic Hudson. Here the Catskill mountains raised their lofty summits; and there the hills came sloping down to the water's edge. Here he pointed to an aged and venerable oak, which having escaped the levelling axe of man, seemed almost to defy the blasting storm and desolating hand of time; and there, he bade me observe an extended tract of wood, 


\section{WANDERINGS IN SOUTH AMERICA}

by which I might form an idea how rich and grand the face of the country had once been. Here it was that, in the great and momentous struggle, the colonists lost the day; and there, they carried all before them:-

"They closed full fast, on every side

No slackness there was found;

And many a gallant gentleman

Lay gasping on the ground.',

Here, in fine, stood a noted regiment; there, moved their great captain; here, the fleets fired their broadsides; and there, the whole force rushed on to battle:-

"Hic Dolopum manus, hic magnus tendebat Achilles, Classibus hic locus, hic acies certare solebat."

At tea-time we took our tea together, and the next morning this worthy American walked up with me to the inn in Albany, shook me by the hand, and then went his way. I bade him farewell, and again farewell, and hoped that fortune might bring us together again once more. Possibly she may yet do so; and should it be in England, I will take him to my house, as an old friend and acquaintance, and offer him my choicest cheer.

It is at Albany that the great canal opens into the Hudson, and joins the waters of this river to those of Lake Erie. The Hudson, at the city of Albany, is distant from Lake Erie about three hundred and sixty miles. The level of the lake is five hundred and sixty-four feet higher than the 
Hudson, and there are eighty-one locks on the canal. It is to the genius and perseverance of De Witt Clinton that the United States owe the almost incalculable advantages of this inland navigation. "Exegit monumentum ære perennius." You may either go along it all the way to Buffalo, on Lake Erie, or by the stage; or sometimes on one and then in the other, just as you think fit. Grand, indeed, is the scenery by either route, and capital the accommodations. Cold and phlegmatic must he be who is not warmed into admiration by the surrounding scenery, and charmed with the affability of the travellers he meets on the way.

This is now the season of roving, and joy and merriment for the gentry of this happy country. Thousands are on the move from different parts of the Union for the springs and lakes, and the falls of Niagara. There is nothing haughty or forbidding in the Americans; and wherever you meet them, they appear to be quite at home. This is exactly what it ought to be, and very much in favour of the foreigner who journeys amongst them. The immense number of highly polished females who go in the stages to visit the different places of amusement, and see the stupendous natural curiosities of this extensive country, incontestably proves that safety and convenience are ensured to them, and that the most distant attempt at rudeness would, by common consent, be immediately put down.

By the time I had got to Schenectady, I began strongly to suspect that I had come into the wrong country to look for bugs, bears, brutes, and buf- 


\section{WANDERINGS IN SOUTH AMERICA}

faloes. It is an enchanting journey from Albany to Schenectady, and from thence to Lake Erie. The situation of the city of Utica is particularly attractive; the Mohawk running close by it, the fertile fields and woody mountains, and the falls of Trenton, forcibly press the stranger to stop a day or two here before he proceeds onward to the lake.

At some far-distant period, when it will not be possible to find the place where many of the celebrated cities of the East once stood, the world will have to thank the United States of America for bringing their names into the western regions. It is, indeed, a pretty thought of these people to give to their rising towns the names of places so famous and conspicuous in former times.

As I was sitting one evening under an oak, in the high grounds behind Utica, I could not look down upon the city without thinking of Cato and his misfortunes. Had the town been called Crofton, or Warmfield, or Dewshury, there would have keen nothing remarkable in it; but Utica at once revived the scenes at school long past and half forgotten, and carried me with full speed back again to Italy, and from thence to Africa. I crossed the Rubicon with Cæsar; fought at Pharsalia; saw poor Pompey into Larissa, and tried to wrest the fatal sword from Cato's hand in Utica. W'ren I perceived he was no more, I mourned over the noble-minded man who took that part which he thought would most benefit his country. There is something magnificent in the idea of a man taking by choice the conquered side. The Roman gods themselves did otherwise. 
"Victrix causa Diis placuit, sed victa Catoni."

"In this did Cato with the Gods divide,

They chose the conquering, he the conquer'd side."

'The whole of the country from Utica to Buffalo is pleasing; and the intervening of the inland lakes, large and deep and clear, adds considerably to the effect. The spacious size of the inns, their excellent provisions, and the attention which the traveller receives in going from Albany to Buffalo, must at once convince him that this country is very much visited by strangers; and he will draw the conclusion that there must be something in it uncommonly interesting to cause so many travellers to pass to and fro.

Nature is losing fast her ancient garb, and putting on a new dress in these extensive regions. Most of the stately timber has been carried away; thousands of trees are lying prostrate on the ground; while meadows, corn-fields, villages, and pastures are ever and anon bursting upon the traveller's view as he journeys on throngh the remaining tracts of wood. I wish I conld say a word or two for the fine timber which is yet standing. Spare it, gentle inhabitants, for your country's sake; these noble sons of the forest beantify your landscapes beyond all description; when they are gone, a century will not replace their loss; they cannot, they must not fall; their vernal bloom, their summer richness and autmmnal tints, please and refresh the eye of man; and even when the days of joy and warmth are fled, the wintry blast soothes the listening ear 
with a sublime and pleasing melancholy as it howls through their naked branches.

\author{
"Around me trees unnumber'd rise, \\ Beautiful in various dyes: \\ The gloomy pine, the poplar blue, \\ The yellow beech, the sable yew; \\ The slender fir, that taper grows, \\ The sturdy oak, with broad-spread boughs.',
}

A few miles before you reach Buffalo, the road is low and bad, and in stepping out of the stage I sprained my foot very severely; it swelled to a great size, and caused me many a day of pain and mortification, as will be seen in the sequel.

Buffalo looks down on Lake Erie, and possesses a fine and commodious inn. At a little distance is the Black Rock, and there you pass over to the Canada side. A stage is in waiting to convey you some sixteen or twenty miles down to the falls. Long before you reach the spot you hear the mighty roar of waters, and see the spray of the far-famed falls of Niagara, rising up like a column to the heavens, and mingling with the passing clouds.

At this stupendous cascade of nature, the waters of the lake fall one hundred and seventysix feet perpendicular. It has been calculated, I forget by whom, that the quantity of water discharged down this mighty fall, is six hundred and seventy thousand two hundred and fifty-five tons per minute. There are two large inns on the Canada side; but, after you have satisfied your curiosity in viewing the falls, and in seeing the rainbow in the foam far below where you are 
standing, do not, I pray you, tarry long at either of them. Cross over to the American side, and there you will find a spacious inn, which has nearly all the attractions: there you meet with great attention, and every accommodation.

The day is passed in looking at the falls, and in sauntering up and down the wooded and rocky environs of the Niagara; and the evening is often enlivened by the merry dance.

Words can hardly do justice to the unaffected ease and elegance of the American ladies who visit the falls of Niagara. The traveller need not rove in imagination through Circassia in search of fine forms, or through England, France, and Spain, to meet with polished females. The numbers who are continually arriving here from all parts of the Union confirm the justness of this remark.

I was looking one evening at a dance, being unable to join in it on account of the accident I had received near Buffalo, when a young American entered the ball-room with such a becoming air and grace, that it was impossible not to have been struck with her appearance.

\footnotetext{
"Her bloom was like the springing flower

That sips the silver dew,

The rose was budded in her cheek,

Just opening to the view."
}

I could not help feeling a wish to know where she had

"Into such beauty spread, and blown so fair."

Upon inquiry, I found that she was from the city 


\section{WANDERINGS IN SOUTH AMERICA}

of Albany. The more I looked at the fair Albanese, the more I was convinced, that in the United States of America may be found grace and beauty and symmetry equal to anything in the old world.

I now for good and all (and well I might) gave up the idea of finding bugs, bears, brutes, and buffaloes in this country, and was thoroughly satisfied that I had laboured under a great mistake in suspecting that I should ever meet with them.

I wished to join in the dance where the fair Albanese was "to brisk notes in cadence beating," but the state of my unlucky foot rendered it impossible; and as I sat with it reclined upon a sofa, full many a passing gentleman stopped to inquire the cause of my misfortune, presuming at the same time that I had got an attack of gout. Now this surmise of theirs always mortified me; for I never had a fit of gout in my life, and moreover, never expect to have one.

In many of the inns in the United States, there is an album on the table, in which travellers insert their arrival and departure, and now and then indulge in a little flash or two of wit.

I thought, under existing circumstances, that there would be no harm in briefly telling my misadventure; and so, taking up the pen, I wrote what follows; and was never after asked a single question about the gout.

"C. Waterton, of Walton-Hall, in the county of York, England, arrived at the Falls of Niagara in July, 1824, and begs leave to pen down the following dreadful accident:- 


\section{WANDERINGS IN SOUTH AMERICA 267}

"He sprained his foot, and hurt his toe, On the rough road near Buffalo.

It quite distresses him to stagger aLong the sharp rocks of famed Niagara.

So thus he's doomed to drink the measure

Of pain, in lieu of that of pleasure.

On Hope's delusive pinions borne,

He came for wool, and goes back shorn.

$N$. B.-Here he alludes to nothing but

Th' adventure of his toe and foot;

Save this,-he sees all that which ean

Delight and charm the soul of man,

But feels it not,- -becanse his toe

And foot together plague him so.",

I remember once to have sprained my ankle very violently, many years ago, and that the doctor ordered me to hold it under the pump two or three times a day. Now, in the United States of America, all is upon a grand scale, except taxation; and I am convinced that the traveller's ideas become much more enlarged as he journeys through the country. This being the case, I can easily account for the desire I felt to hold my sprained foot under the fall of Niagara. I descended the winding staircase which has been made for the accommodation of travellers, and then hobbled on to the scene of action. As I held $\mathrm{my}$ leg under the fall, I tried to meditate on the immense difference there was betwixt a house-pump and this tremendous cascade of nature, and what effect it might have upon the sprain; but the magnitude of the subject was too overwhelming, and I was obliged to drop it.

Perhaps, indeed, there was an unwarrantable tincture of vanity in an unknown wanderer wish- 


\section{WANDERINGS IN SOUTH AMERICA}

ing to have it in his power to tell the world, that he had held his sprained foot under a fall of water which discharges six hundred and seventy thousand two hundred and fifty-five tons per minute. A gentle purling stream would have suited better. Now, it would have become Washington to have quenched his battle-thirst in the fall of Niagara; and there was something royal in the idea of Cleopatra drinking pearl-vinegar, made from the grandest pearl in Egypt; and it became Caius Marius to send word, that he was sitting upon the ruins of Carthage. Here, we have the person suited to the thing, and the thing to the person.

If, gentle reader, thou wouldst allow me to indulge a little longer in this harmless penerrantry, I would tell thee, that I have had my ups and downs in life, as well as other people; for I have climbed to the point of the conductor above the cross on the top of St. Peter's, in Rome, and left my glove there. I have stood on one foot, upon the Guardian Angel's head, on the castle of St. Angelo; and, as I have just told thee, I have been low down under the fall of Niagara. But this is neither here nor there; let us proceed to something else.

When the pain in my foot had become less violent, and the swelling somewhat abated, I could not resist the inclination I felt to go down Ontario, and so on to Montreal and Quebec, and take Lakes Champlain and George in my way back to Albany.

Just as I had made up my mind to it, a family from the Bowling-green, in New York, who was 
going the same route, politely invited me to join their party. Nothing could be more fortunate. They were highly accomplished. The young ladies sang delightfully; and all contributed their portion, to render the tour pleasant and amusing.

Travellers had already filled the world with descriptions of the bold and sublime scenery from Lake Erie to Quebec:-

\footnotetext{
"The fountain's fall, the river's flow, The woody valleys, warm and low; The windy summit, wild and high, Roughly rushing to the sky."
}

And there is scarce one of them who has not described the achievements of former and latter times, on the different battle-grounds. Here, great Wolfe expired. Brave Montcalm was carried, mortally wounded, through yonder gate. Here fell the gallant Brock; and there General Sheaffee captured all the invaders. And in yonder harbour may be seen the mouldering remnants of British vessels. Their hour of misfortune has long passed away. The victors have now no use for them in an inland lake. Some have already sunk, while others, dismantled and half-dismasted, are just above the water, waiting, in shattered state, that destiny which must sooner or later destroy the fairest works of man.

The excellence and despatch of the steam-boats, together with the company which the traveller is sure to meet with at this time of the year, render the trip down to Montreal and Quebec very agreeable.

The Canadians are a quiet, and apparently 


\section{WANDERINGS IN SOUTH AMERICA}

a happy people. They are very courteous and affable to strangers. On comparing them with the character which a certain female traveller, a journalist, has thought fit to give them, the stranger might have great doubts whether or not he were amongst the Canadians.

Montreal, Quebec, and the falls of Montmorency, are well worth going to see. They are making tremendous fortifications at Quebec. It will be the Gibraltar of the new world. When one considers its distance from Europe, and takes a view of its powerful and enterprising neighbour, Virgil's remark at once rushes into the mind,

"Sic ros non robis nidificatis aves."

I left Montreal with regret. I had the good fortune to be introduced to the Professors of the College. These fathers are a very learned and worthy set of gentlemen; and on my taking leave of them, I felt a heaviness at heart, in reflecting that I had not more time to cultivate their acquaintance.

In all the way from Buffalo to Quebec, I only met with one bug; and I cannot even swear that it belonged to the United States. In going down the St. Lawrence, in the steam-boat, I felt something crossing over my neck; and on laying hold of it with my finger and thumb, it turned out to be a little half-grown, ill-conditioned bug. Now, whether it were going from the American to the Canada side, or from the Canada to the American, and had taken the advantage of my shoulders to ferry itself across, I could not tell. Be this as it 
may, I thought of my uncle 'Toby and the fly ; and so, in lieu of placing it upon the deck, and then putting my thumb-nail vertically upon it, I quietly chucked it amongst some baggage that was close by, and recommended it to get ashore by the first opportunity.

When we had seen all that was worth seeing in Quebec and at the falls of Montmorency, and had been on board the enormous ship Columbus, we returned for a day or two to Montreal, and then proceeded to Saratoga by Lakes Champlain and George.

The steam-boat from Quebec to Montreal had above five hundred Irish emigrants on board. They were going "they hardly knew whither," far away from dear Ireland. It made one's heart ache to see them all huddled together, without any expectation of ever revisiting their native soil. We feared that the sorrow of leaving home for ever, the miserable accommodation on board the ship which had brought them away, and the tossing of the angry ocean, in a long and dreary voyage, would have rendered them callous to good behaviour. But it was quite otherwise. They conducted themselves with great propriety. Every American on board seemed to feel for them. And then "they were so full of wretchedness. Need and oppression stared in their eyes. Upon their backs hung ragged misery. The world was not their friend.' "Poor dear Ireland," exclaimed an aged female, as I was talking to her, "I shall never see it any more!"' and then her tears began to flow. Probably the scenery on the banks of the St. Lawrence recalled to her mind 


\section{WANDERINGS IN SOUTH AMERICA}

the remembrance of spots once interesting to her:

"The lovely daughter,-lovelier in her tears, The fond companion of her father's years, Here silent stood,-neglectful of her charms, And left her lover's for her father's arms. With louder plaints the mother spoke her woes, And blessed the cot where every pleasure rose; And pressed her thoughtless babes with many a toar, And clasped them close, in sorrow doubly dear, While the fond husband strove to lend relief, In all the silent manliness of grief."

We went a few miles out of our route to take a look at the once formidable fortress of Ticonderoga. It has long been in ruins, and seems as if it were doomed to moulder quite away.

"Ever and anon there falls

Huge heaps of hoary moulder'd walls.

But time has seen, that lifts the low

And level lays the lofty brow,

Has seen this ruin'd pile complete,

Big with the vanity of state;

But transient is the smile of fate."

The scenery of Lake George is superb; the inn remarkably spacious and well attended; and the conveyance from thence to Saratoga very good. He must be sorely afflicted with spleen and jaundice, who, on his arrival at Saratoga, remarks, there is nothing here worth coming to see. It is a gay and fashionable place; has four uncommonly fine hotels; its waters, for medicinal virtues, are surpassed by none in the known world; and it is resorted to, throughout the whole of the summer, by foreigners and natives of the first 
consideration. Saratoga pleased me much; and afforded a fair opportunity of forming a pretty correct idea of the gentry of the United States.

There is a pleasing frankness, and ease and becoming dignity, in the American ladies; and the good humour, and absence of all haughtiness and puppyism in the gentlemen, must, no doubt, impress the traveller with elevated notions of the company who visit this famous spa.

During my stay here, all was joy, and affability, and mirth. In the mornings the ladies played and sang for us; and the evenings were generally enlivened with the merry dance. Here I bade farewell to the charming family, in whose company I had passed so many happy days, and proceeded to Albany.

The stage stopped a little while in the town of Troy. The name alone was quite sufficient to recall to the mind scenes long past and gone. Poor king Priam! Napoleon's sorrows, sad and piercing as they were, did not come up to those of this ill-fated monarch. The Greeks first set his town on fire, and then began to bully:-

"Incensâ Danai dominantur in urbe."

One of his sons was slain before his face; "ante ora parentum, concidit." Another was crushed to mummy by boa-constrictors ; "immensis orbibus angues." His city was rased to the ground, "jacet Ilion ingens." And Pyrrhus ran him through with his sword, "capulo tenus abdidit ensem." This last may be considered as a fortunate stroke for the poor old king. Had his life been spared at this juncture he could not have 


\section{WANDERINGS IN SOU'TH AMERICA}

lived long. He must have died broken-hearted. He would have seen his son-in-law, once master of a noble stud, now, for want of a horse, obliged to carry off his father, up hill, on his own back, "cessi et sublato, montem genitore petivi." He would have heard of his grandson being thrown neck and heels from a high tower, "mittitur Astyanax illis de turribus." He would have been informed of his wife tearing out the eyes of king Odrysius with her finger nails, "digitos in perfida lumina condit." Soon after this, losing all appearance of woman, she became a bitch,

"Perdidit infelix, hominis post omnia formam,"

and rent the heavens with her howlings,

"Externasque novo latratu terruit auras."

Then, becoming distracted with the remembrance of her misfortunes, "veterum memor illa malorum," she took off howling into the fields of Thrace,-

"Tum quoque Sithonios, ululavit mœsta per agros."

Juno, Jove's wife and sister, was heard to declare, that poor Hecuba did not deserve so terrible a fate,-

"Ipsa Jovis conjuxque sororque,

Eventus Hecubam meruisse negaverit illos."

Had poor Priam escaped from Troy, one thing, and only one thing, would have given him a small ray of satisfaction, viz., he would have heard of one of his daughters nobly preferring to leave this 
world, rather than live to become servant-maid to old Grecian ladies:-

“Non ego Myrmidonum sedes, Dolopumve superbas, Adspiciam, aut Graiis servitum matribus ibo."

At some future period, should a foreign armed force, or intestine broils (all which heaven avert), raise Troy to the dignity of a fortified city, Virgil's prophecy may then be fulfilled,

"Atque iterum ad Trojam magnus mittetur Achilles."

After leaving Troy, I passed through a fine country to Albany; and then proceeded by steam down the Hudson to New York.

Travellers hesitate whether to give the preference to Philadelphia or to New York. Philadelphia is certainly a noble city, and its environs beautiful; but there is a degree of quiet and sedateness in it, which, though no doubt very agreeable to the man of calm and domestic habits, is not so attractive to one of speedy movements. The quantity of white marble which is used in the buildings, gives to Philadelphia a gay and lively appearance; but the sameness of the streets, and their crossing each other at right angles, are somewhat tiresome. The water-works which supply the city, are a proud monument of the skill and enterprise of its inhabitants; and the market is well worth the attention of the stranger.

When you go to Philadelphia, be sure not to forget to visit the Museum. It will afford you a great treat. Some of Mr. Peale's family are constantly in it, and are ever ready to show the curiosities to strangers, and to give them every 


\section{WANDERINGS IN SOUTH AMERICA}

necessary information. Mr. Peale has now passed his eightieth year, and appears to possess the vivacity, and, I may almost add, the activity of youth.

To the indefatigable exertions of this gentleman is the western world indebted for the possession of this splendid museum. Mr. Peale is, moreover, an excellent artist. Look attentively, I pray you, at the portrait he has taken of himself, by desire of the State of Pennsylvania. On entering the room he appears in the act of holding up a curtain, to show you his curiosities. The effect of the light upon his head is infinitely striking. I have never seen anything finer in the way of light and shade. The skeleton of the mammoth is a national treasure. I could form but a faint idea of it by description, until I had seen it. It is the most magnificent skeleton in the world. The city ought never to forget the great expense Mr. Peale was put to, and the skill and energy he showed, during the many months he spent in searching the swamps, where these enormous bones had been concealed from the eyes of the world for centuries.

The extensive squares of this city are ornamented with well-grown and luxuriant trees. Its unremitting attention to literature might cause it to be styled the Athens of the United States. Here, learning and science have taken up their abode. The literary and philosophical associations, the enthusiasm of individuals, the activity of the press, and the cheapness of the publications, ought to raise the name of Philadelphia to an elevated situation in the temple of knowledge. 
From the press of this eity came Wilson's famous "Ornithology." By observing the birds in their native haunts, he has been enabled to purge their history of numberless absurdities, which inexperienced theorists had introduced into it. It is a pleasing and a brilliant work. We have no description of birds in any European publication that can come up to this. By perusing Wilson's "Ornithology" attentively before I left England, I knew where to look for the birds, and immediately recognized them in their native land.

Since his time, I fear the White-headed Eagles have been much thinned. I was perpetually looking out for them, but saw very few. One or two came now and then, and soared in lofty flight over the falls of Niagara. The Americans are proud of this bird in effigy, and their hearts rejoice when its banner is unfurled. Could they not then be persuaded to protect the white-headed eagle, and allow it to glide in safety over its own native forests? Were I an American, I should think I had committed a kind of sacrilege in killing the white-headed eagle. The Tbis was held sacred by the Egyptians; the Hollanders protect the Stork; the Vulture sits unmolested on the top of the houses in the city of Angustura; and Robin-redbreast, for his charity, is cherished by the English :-

"No burial these pretty babes

Of any man receives,

Till robin-red-breast painfully

Did cover them with leaves."

${ }^{3}$ The fault against grammar is lost in the beauty of the idea. 


\section{WANDERINGS IN SOUTH AMERICA}

Poor Wilson was smote by the hand of death, before he had finished his work. Prince Charles Buonaparte, nephew to the late emperor $\mathrm{Na}$ poleon, aided by some of the most scientific gentlemen of Pennsylvania, is continuing this valuable and interesting publication.

New York, with great propriety, may be called the commercial capital of the new world:-

"Urbs augusta potens, nulli cessura."

Ere long, it will be on the coast of North America what Tyre once was on that of Syria. In her port are the ships of all nations; and in her streets is displayed merchandise from all parts of the known world. And then the approach to it is so enchanting! The verdant fields, the woody hills, the farms, and country houses, form a beautiful landscape as you sail up to the city of New York.

Broadway is the principal street. It is three miles and a half long. I am at a loss to know where to look for a street, in any part of the world, which has so many attractions as this. There are no steam-engines to annoy you by filling the atmosphere full of soot and smoke; the houses have a stately appearance; while the eye is relieved from the perpetual sameness, which is common in most streets, by lofty and luxuriant trees.

Nothing can surpass the appearance of the American ladies, when they take their morning walk, from twelve to three, in Broadway. The stranger will at once see that they have rejected the extravagant superfluities which appear in the 
London and Parisian fashions; and have only retained as much of those costumes, as is becoming to the female form. This, joined to their own just notions of dress, is what renders the New York ladies so elegant in their attire. The way they wear the Leghorn hat deserves a remark or two. With us, the formal hand of the milliner binds down the brim to one fixed shape, and that none of the handsomest. The wearer is obliged to turn her head full ninety degrees before she can see the person who is standing by her side. But in New York the ladies have the brim of the. hat not fettered with wire, or tape, or ribbon, but. quite free and undulating; and by applying the hand to it, they can conceal or expose as much of the face as circumstances require. This hiding and exposing of the face, by the bye, is certainly a dangerous movement, and often fatal to the. passing swain. I am convinced in my own mind, that many a determined and unsuspecting bachelor, has been shot down by this sudden manœuvre, before he was aware that he was within reach of the battery.

The American ladies seem to have an ablorrence (and a very just one too) of wearing caps. When one considers for a moment, that women wear the hair long, which nature has given them both for an ornament and to keep the head warm, one is apt to wonder, by what perversion of good taste they can be induced to enclose it in a cap. A mob cap, a lace cap, a low cap, a high cap, a flat cap, a cap with ribbons dangling loose, a cap with ribbons tied under the chin, a peak cap, an angular cap, a round cap, and a pyramid cap! How would 


\section{WANDERINGS IN SOUTH AMERICA}

Canova's Venus look in a mob cap? If there be any ornament to the head in wearing a cap, it must surely be a false ornament. The American ladies are persuaded that the head can be ornamented without a cap. A rose-bud or two, a woodbine, or a sprig of eglantine, look well in the braided hair; and if there be raven locks, a lily or a snowdrop may be interwoven with effect.

Now that the packets are so safe, and make such quick passages to the United States, it would be as well if some of our head milliners would go on board of them, in lieu of getting into the Diligence for Paris. They would bring back more taste, and less caricature. And if they could persuade a dozen or two of the farmers' servant girls to return with them, we should soon have proof positive, that as good butter and cheese may be made with the hair braided up, and a daisy or primrose in it, as butter and cheese made in a cap of barbarous shape; washed, perhaps, in soap-suds last new moon.

New York has very good hotels, and genteel boarding houses. All charges included, you do not pay above two dollars a day. Little enough, when you consider the capital accommodations, and the abundance of food.

In this city, as well as in others which I visited, every body seemed to walk at his ease. I could see no inclination for jostling; no impertinent staring at you; nor attempts to create a row in order to pick your pocket. I would stand for an hour together in Broadway, to observe the passing multitude. There is certainly a gentleness in these people, both to be admired and imitated. 
I could see very few dogs, still fewer cats, and but a very small proportion of fat women in the streets of New York. The climate was the only thing that I had really to find fault with; and as the autumn was now approaching, I began to think of preparing for warmer regions.

Strangers are apt to get violent cold, on account of the sudden change of the atmosphere. The noon would often be as warm as tropical weather, and the close of day cold and chilly. This must sometimes act with severity upon the newly-arrived stranger; and it requires more care and circumspection than I am master of to guard against it. I contracted a bad and obstinate cough, which did not quite leave me till I had got under the regular heat of the sun, near the equator.

I may be asked, was it all good fellowship and civility during my stay in the United States? Did no forward person cause offence, was there no exhibition of drunkenness, or swearing, or rudeness; or display of conduct which disgraces civilized man in other countries? I answer, very few indeed: scarce any worth remembering, and none worth noticing. These are a gentle and a civil people. Should a traveller, now and then in the long run, witness a few of the scenes alluded to, he ought not, on his return home, to adduce a solitary instance or two, as the custom of the country. In roving through the wilds of Guiana, I have sometimes seen a tree hollow at heart, shattered and leafless; but I did not on that account condemn its vigorous neighbours, and put down a memorandum that the woods were bad; 


\section{WANDERINGS IN SOUTH AMERICA}

on the contrary, I made allowances: a thunderstorm, the.whirlwind, a blight from heaven might have robbed it of its bloom, and caused its present forbidding appearance. And, in leaving the forest, I carried away the impression, that though some few of the trees were defective, the rest were an ornament to the wilds, full of uses and virtues, and capable of benefiting the world in a superior degree.

A man generally travels into foreign countries for his own ends; and I suspect there is scarcely an instance to be found of a person leaving his own home solely with the intention of benefiting those amongst whom he is about to travel. A commercial speculation, curiosity, a wish for information, a desire to reap benefit from an acquaintance with our distant fellow-creatures, are the general inducements for a man to leave his own fire-side. This ought never to be forgotten; and then the traveller will journey on under the persuasion that it rather becomes him to court than expect to be courted, as his own interest is. the chief object of his travels. With this in view, he will always render himself pleasant to the natives; and they are sure to repay his little acts of courtesy with ample interest, and with a fund of information which will be of great service to. him:

While in the United States, I found our western brother a very pleasant fellow; but his portrait has been drawn in such different shades, by different travellers who have been through his territory, that it requires a personal interview before. a correct idea can be formed of his true colours. 
$\mathrm{He}$ is very inquisitive; but it is quite wrong on that account to tax him with being of an impertinent turn. He merely interrogates you for information; and when you have satisfied him on that score, only ask him in your turn for an account of what is going on in his own country, and he. will tell you everything about it with great good. humour, and in excellent language. He has cer-tainly hit upon the way (but I could not make: out by what means) of speaking a much. purer English language than that which is in. general spoken on the parent soil. This astonished me much; but it is really the case. Amongst his many good qualities, he has one. unenviable, and, I may add, a bad propensity: he is immoderately fond of smoking. He may say, that he learned it from his nurse, with whom it was once much in vogue. In Dutch. William's time (he was a man of bad taste), the: English gentleman could not do without his pipe. During the short space of time that corporal Trim was at the inn inquiring after poor Lefevre's health, my uncle Toby had knocked the ashes out of three pipes. "It was not till my uncle Toby" had knocked the ashes out of his third pipe," \&c. Now these times have luckily gone by, and the custom of smoking amongst genteel Englishmen has nearly died away with them; it is a foul custom; it makes a foul mouth, and a foul place where the smoker stands; however, every nation has its whims. John Bull relishes stinking venison; a Frenchman depopulates whole swamps in quest of frogs; a Dutchman's pipe is never out: of his mouth; a Russian will eat tallow candles; 


\section{WANDERINGS IN SOUTH AMERICA}

and the American indulges in the cigar. "De gustibus non est disputandrum."

Our western brother is in possession of a country replete with everything that can contribute to the happiness and comfort of mankind. His code of laws, purified by experience and common sense, has fully answered the expectations of the public. By acting up to the true spirit of this code, he has reaped immense advantages from it. His advancement, as a nation, has been rapid beyond all calculation; and, young as he is, it may be remarked, withont any impropriety, that he is now actually reading a salutary lesson to the rest of the civilized world.

It is but some forty years ago, that he had the dispute with his nurse about a dish of tea. She wanted to force the boy to drink it according to her own receipt. He said, he did not like it, and that it absolutely made him ill. After a good deal of sparring, she took up the birch rod, and began to whip him with an uncommon degree of asperity. When the poor lad found that he must either drink the nauseous dish of tea or be flogged to death, he turned upon her in self-defence; showed her to the outside of the nursery door, and never more allowed her to meddle with his affairs.

Since the independence, the population has increased from three to ten millions. A fine navy has been built; and everything attended to that could ensure prosperity at home, and respect abroad.

The former wilds of North America bear ample testimony to the achievements of this enterprising people. Forests have been cleared away, swamps 
drained, canals dug, and flourishing settlements established. From the shores of the Atlantic an immense column of knowledge has rolled into the interior. The Mississippi, the Ohio, the Missouri, and their tributary streams, have been wonderfully benefited by it. It now seems as if it were advancing towards the stony mountains and probably will not become stationary till it reaches the Pacific Ocean. This almost immeasurable territory affords a shelter and a home to mankind in general: Jew or Gentile, king's-man or republican, he meets with a friendly reception in the United States. His opinions, his persecutions, his errors, or mistakes, however they may have injured him in other countries, are dead, and of no avail on his arrival here. Provided he keeps the peace, he is sure to be at rest.

Politicians of other countries imagine that intestine feuds will cause a division in this commonwealth; at present there certainly appears to be no reason for such a conjecture. Heaven forbid that it should happen! The world at large would suffer by it. For ages yet to come, may this great commonwealth continue to be the United States of North America.

The sun was now within a week or two of passing into the southern hemisphere, and the mornings and evenings were too cold to be comfortable. I embarked for the island of Antigua, with the intention of calling at the different islands in the Carribean sea, on my way once more towards the wilds of Guiana. 


\section{CHAPTER II}

We were thirty days in making Antigua, and thanked Providence for ordering us so long a passage. A tremendous gale of wind, approaching to a hurricane, had done much damage in the West Indies. Had our passage been of ordinary length, we should inevitably have been caught in the gale.

St. John's is the capital of Antigua. In better times it may have had its gaities and amusements. At present, it appears sad and woe-begone. The houses, which are chiefly of wood, seem as if they had not had a coat of paint for many years; the streets are uneven and ill-paved; and as the stranger wanders through them, he might fancy that they would afford a congenial promenade to the man who is about to take his last leave of surrounding worldly misery, before he hangs himself. There had been no rain for some time, so that the parched and barren pasture near the town might, with great truth, be called Rosinante's own. The mules feeding on them, put you in mind of Ovid's description of famine:-

"Dura cutis, per quam spectari viscera possent."

It is somewhat singular, that there is not a single river or brook in the whole island of Antigua. In this it differs from Tartary in the other world; 


\section{WANDERINGS IN SOU'TH AMERICA 287}

which, according to old writers, has five rivers; viz., Acheron, Phlegethon, Cocytus, Styx, and Lethe.

In this island I found the Red Start, described in Wilson's "Ornithology of the United States." I wished to learn whether any of these birds remain the whole year in Antigua, and breed there; or whether they all leave it for the north when the sun comes out of the southern hemisphere; but, upon inquiry, I could get no information whatever.

After passing a dull week here, I sailed for Guadaloupe, whose bold and cloud-capped mountains have a grand appearance as you approach the island. Basseterre, the capital, is a neat town, with a handsome public walk in the middle of it, well shaded by a row of fine tamarind trees on each side. Behind the town, La Souffriere raises its high romantic summit; and on a clear day, you may see the volcanic smoke which issues from it.

Nearly midway, betwixt Guadaloupe and Dominica, you descry the Saintes. Though high, and bold, and rocky, they have still a diminutive appearance when compared with their two gigantic neighbours. You just see Marigalante to windward of them, some leagues off, about a yard high in the horizon.

Dominica is majestic in high and rugged mountains. As you sail along it, you cannot help admiring its beautiful coffee plantations, in places so abrupt and steep, that you would pronounce them almost inaccessible. Roseau, the capital, is but a small town, and has nothing attractive ex- 


\section{WANDERINGS IN SOUTH AMERICA}

cept the well-known hospitality of the present harbour-master, who is particularly attentive to strangers, and furnishes them with a world of information concerning the West Indies. Roseau has seen better days; and you can trace good taste and judgment in the way in which the town has originally been laid out.

Some year's ago it was visited by a succession of misfortunes, which smote it so severely, that it has never recovered its former appearance. A strong French fleet bombarded it; while a raging fire destroyed its finest buildings. Some time after, an overwhelming flood rolled down the gullies and fissures of the adjacent mountains, and carried all before it. Men, women, and children, houses, and property, were all swept away by this mighty torrent. The terrible scene was said to beggar all description, and the loss was immense.

Dominica is famous for a large species of Frog, which the inhabitants keep in readiness to slaughter for the table. In the woods of this island, the large Rhinoceros Beetle is very common; it measures above six inches in length. In the same woods is found the beantiful Humming-bird, the breast and throat of which are of a brilliant changing purple. I have searched for this bird in Brazil, and through the whole of the wilds from the Rio Branco, which is a branch of the Amazons, to the river Paumaron, but never could find it. I was told by a man in the EgyptianHall, in Piccadilly, that this humming-bird is found in Mexico; but upon questioning him more about it, his information seemed to have been 
acquired by hearsay; and so I concluded that it does not appear in Mexico. I suspect that it is never found out of the Antilles.

After leaving Dominica, you soon reach the grand and magnificent island of Martinico. St. Pierre, its capital, is a fine town, and possesses every comfort. The inhabitants seem to pay considerable attention to the cultivation of the tropical fruits. A stream of water runs down the streets with great rapidity, producing a pleasing effect as you pass along.

Here I had an opportunity of examining a Cuckoo, which had just been shot. It was exactly the same as the Metallic Cuckoo in Wilson's "Ornithology." They told me it is a migratory bird in Martinico. It probably repairs to this island after its departure from the United States.

At a little distance from Martinico, the celebrated Diamond Rock rises in insulated majesty out of the sea. It was fortified during the last war with France, and bravely defended by an English captain.

In a few hours from Martinico, you are at St. Lucie, whose rough and towering mountains fill you with sublime ideas, as you approach its rocky shore. The town Castries is quite embayed. It was literally blown to pieces by the fatal hurricane, in which the unfortunate governor and his lady lost their lives. Its present forlorn and gloomy appearance, and the grass which is grown up in the streets, too plainly show that its hour of joy is passed away; and that it is in mourning, as it were, with the rest of the British West Indies. 
From St. Lucie, I proceeded to Barbadoes in quest of a conveyance to the island of Trinidad.

Near Bridgetown, the capital of Barbadoes, I saw the metallic cuckoo, already alluded to.

Barbadoes is no longer the merry island it was when I visited it some years ago:-

"Infelix habitum, temporis hujus habet."

There is an old song, to the tune of La Belle Catharine, which must evidently have been composed in brighter times:-

\footnotetext{
"Come let us dance and sing,

While Barbadoes bells do ring;

Quashi scrapes the fiddle-string,

And Venus plays the lute."
}

Quashi's fiddle was silent; and mute was the lute of Venus during my stay in Barbadoes. The difference betwixt the French and British islands was very striking. 'The first appeared happy and content; the second were filled with murmurs and complaints. The late proceedings in England, concerning slavery, and the insurrection in Demerara, had evidently caused the gloom. The abolition of slavery is a question full of benevolence and fine feelings, difficulties and danger:-

"Tantum ne noceas, dum vis prodesse videto."

It requires consummate prudence, and a vast fund of true information, in order to draw just conclusions on this important subject. Phaeton, by awkward driving, set the world on fire: "Sylvæ cum montibus ardent." Dredalus gave his son a pair 
of wings without considering the consequence; the boy flew out of all bounds, lost his wings, and tumbled into the sea:-

\section{"Icarus, Icariis nomina fecit aquis."}

When the old man saw what had happened, he damned his own handicraft in wing-making; "devovitque suas artes." Prudence is a cardinal virtue :-

$$
\text { "Omnia consultâ mente gerenda tegens." }
$$

Foresight is half the battle. "Hombre apercebido, medio combatido," says Don Quixote, or Sancho, I do not remember which. Had Queen Bess weighed well in her own mind the probable consequences of this lamentable traffic, it is likely she would not have been owner of two vessels in Sir John Hawkins's squadron, which committed the first robbery in negro flesh on the coast of Africa. As philanthropy is the very life and soul of this momentous question on slavery, which is certainly fraught with great difficulties and danger, perhaps it would be as well at present for the nation to turn its thoughts to poor ill-fated Ireland, where oppression, poverty, and rags make a heart-rending appeal to the feelings of the benevolent.

But to proceed. There was another thing which added to the dulness of Barbadoes, and which seemed to have considerable effect in keeping away strangers from the island. The legislature had passed a most extraordinary bill, by virtue of which every person who arrives at Barbadoes is obliged to pay two dollars, and two dollars 
more on his departure from it. It is called the alien bill; and every Barbadian who leaves or returns to the island, and every Englishman too, pays the tax!

Finding no vessel here for Trinidad, I embarked in a schooner for Demerara, landed there after being nearly stranded on a sand-bank, and proceeded without loss of time to the forests in the interior. It was the dry season, which renders a residence in the woods very delightful.

There are three species of Jacamar to be found on the different sand-hills and dry savannas of Demerara; but there is another much larger and far more beantiful to be seen when you arrive in that part of the country where there are rocks. The jacamar has no affinity to the woodpecker or kingfisher nothwithstanding what travellers affirm), either in its haunts or anatomy. The jacamar lives entirely on insects, but never goes in search of them. It sits patiently for hours together on the branch of a tree, and when the incautious insect approaches, it flies at it with the rapidity of an arrow, seizes it, and generally returns to eat it on the branch which it had just quitted. It has not the least attempt at song, is very solitary, and so tame that you may get within three or four yards of it before it takes flight. The males of all the different species which I have examined have white feathers on the throat. I suspect that all the male jacamars hitherto discovered have this distinctive mark. I could learn nothing of its incubation. The Indians informed me that one species of jacamar lays its eggs in the Wood-Ants' nests, which are so frequent in 
the trees of Guiana, and appear like huge black balls. I wish there had been proof positive of this; but the breeding time was over; and in the ants' nests which I examined, I could find no marks of birds having ever been in them. Early in January the jacamar is in fine plumage for the cabinet of the naturalist. The largest species measures ten inches and a half from the point of the beak to the end of the tail; its name amongst the Indians is Una-waya-adoucati, that is, grandfather of the jacamar. It is certainly a splendid bird; and in brilliancy and changeableness of its metallic colours, it yields to none of the Asiatic and African feathered tribe. The colours of the female are nearly as bright as those of the male, but she wants the white feathers on the throat. The large jacamar is pretty common about two hundred miles up the river Demerara.

Here I had a fine opportunity once more of examining the Three-toed Sloth. He was in the house with me for a day or two. Had I taken a description of him as he lay sprawling on the floor, I should have misled the world, and injured natural history. On the ground he appeared really a bungled composition, and faulty at all points; awkwardness and misery were depicted on his countenance; and when I made him advance he sighed as though in pain. Perhaps it was, that by seeing him thus out of his element as it were, that the Count de Buffon, in his history of the sloth, asks the question-" "Why should not some animals be created for misery, since, in the human species, the greatest number of individuals are devoted to pain from the moment of their 


\section{WANDERINGS IN SOUTH AMERICA}

existence?" Were the question put to me, I would answer, I cannot conceive that any of them are created for misery. 'That thousands live in misery there can be no doubt; but then, misery has overtaken them in their path through life, and wherever man has come up with them, I should suppose they have seldom escaped from experiencing a certain proportion of misery.

After fully satisfying myself that it only leads the world into error to describe the sloth while he is on the ground, or in any place except in a tree, I carried the one I had in my possession to his native haunts. As soon as he came in contact with the branch of a tree, all went right with him. I could see as he climbed up into his own country, that he was on the right road to happiness; and felt persuaded more than ever, that the world has hitherto erred in its conjectures concerning the sloth, on account of naturalists, not having given a description of him when he was in the only position in which he ought to have been described, namely, clinging to the branch of a tree.

As the appearance of this part of the country bears great resemblance to Cayenne, and is so near to it, I was in hopes to have found the Grande Gobe Mouche of Buffon, and the septicoloured Tangara, both of which were common in Cayenne; but after many diligent searches, I did not succeed; nor could I learn from the Indians that they had ever seen those two species of birds in these parts.

Here I procured the Grosbeak with a rich scarlet body, and black head and throat. Buffon 
mentions it as coming from America. I had been in quest of it for years, but could never see it, and concluded that it was not to be found in Demerara. The bird is of a greenish brown before it acquires its rich plumage.

Amongst the bare roots of the trees, alongside of this part of the river, a red crab sometimes makes its appearance, as you are passing up and down. It is preyed upon by a large species of Owl, which I was fortunate enough to procure. Its head, back, wings, and tail, are of so dark a brown as almost to appear black. The breast is of a somewhat lighter brown. The belly and thighs are of a dirty yellow white. The feathers round the eyes are of the same dark brown as the rest of the body; and then comes a circle of white, which has the appearance of a large pair of spectacles. I strongly suspect that the dirty yellow white of the belly and thighs has originally been pure white; and that it has come to its present colour by means of the bird darting down upon its prey in the mud. But this is mere conjecture.

Here too, close to the river, I frequently saw the bird called Sun-bird by the English colonists, and Tirana by the Spaniards in the Oroonoque. It is very elegant; and in its outward appearance approaches near to the heron tribe; still it does not live upon fish. Flies and insects are its food; and it takes them just as a heron does fish, by approaching near and then striking with its beak at its prey so quick, that it has no chance to escape. The beautiful mixture of grey, yellow, green, black, white, and chestnut in the plumage 


\section{WANDERINGS IN SOUTH AMERICA}

of this bird, baffles any attempt to give a description of the distribution of them which would be satisfactory to the reader.

There is something remarkable in the great Tinamou, which I suspect has hitherto escaped notice. It invariably roosts in trees; but the feet are so small in proportion to the body of this bulky bird, that they can be of no use to it in grasping the branch; and, moreover, the hind toe is so short, that it does not touch the ground when the bird is walking. The back part of the leg, just below the knee, is quite flat, and somewhat concave. On it are strong pointed scales, which are very rough, and catch your finger as you move it along from the knee to the toe. Now, by means of these scales, and the particular flatness of that part of the leg, the bird is enabled to sleep in safety upon the branch of a tree.

At the close of day the great tinamon gives a loud, monotonous, plaintive whistle, and then immediately springs into the tree. By the light of the full moon, the vigilant and cantious naturalist may see him sitting in the position already described.

The small Tinamou has nothing that can be called a tail. It never lays more than one egg, which is of a chocolate colour. It makes no nests, but merely scratches a little hollow in the sand, generally at the foot of a tree.

Here we have an instance of a bird, the size of a partridge, and of the same tribe, laying only one egg, while the rest of the family, from the peahen to the quail, are known to lay a considerable number. The foot of this bird is very 
smail in proportion, but the back part of the leg bear's no resemblance to that of the larger tinamou; hence one might conclude that it sleeps upon the ground.

Independent of the hollow trees, the Vampires have another hiding-place. They clear out the inside of the large ants' nests, and then take possession of the shell. I had gone about half a day down the river, to a part of the forest where the wallaba-trees were in great plenty. The seeds had ripened, and I was in hopes to have got the large scarlet ara, which feeds on them. But, unfortunately, the time had passed away, and the seeds had fallen.

While ranging here in the forest, we stopped under an ants' nest; and, by the dirt below, conjectured that it had got new tenants. Thinking it no harm to dislodge them, "vi et armis," an Indian boy ascended the tree; but, before he reached the nest, out flew above a dozen Vampires.

I have formerly remarked, that I wished to have it in my power to say, that I had been sucked by the vampire. I gave them many an opportunity, but they always fought shy; and though they now sucked a young man of the Indian breed very severely, as he was sleeping in his hammock in the shed next to mine, they would have nothing to do with me. His great toe seemed to have all the attractions. I examined it minutely as he was bathing it in the river at daybreak. The midnight surgeon had made a hole in it, almost of a triangular shape, and the blood was then running from it apace. His hammock was so defiled and stained with clotted blood, that he 


\section{WANDERINGS IN SOUTH AMERICA}

was obliged to beg an old black woman to wash it. As she was taking it down to the river side, she spread it out before me, and shook her head. I remarked, that I supposed her own toe was too old and tough to invite the Vampire-doctor to get his supper out of it; and she answered, with a grin, that doctors generally preferred young people.

Nobody has yet been able to inform me how it is that the vampire manages to draw such a large quantity of blood, generally from the toe, and the patient, all the time, remain in a profound sleep. I have never heard of an instance of a man waking under the operation. On the contrary, he continues in a sound sleep, and at the time of rising, his eyes first inform him that there has been a thirsty thief on his toe.

The teeth of the vampire are very sharp, and not unlike those of the rat. If it be that he inflicts the wounds with his teeth, (and he seems to have no other instruments), one would suppose that the acuteness of the pain would cause the person who is sucked, to awake. We are in darkness in this matter; and I know of no means by which one might be enabled to throw light upon it. It is to be hoped that some future wanderer through the wilds of Guiana, will be more fortunate than I have been, and catch this nocturnal depredator in the fact. I have once before mentioned that I killed a vampire which measured thirty-two inches from wing to wing extended; but others, which I have since examined, have generally been from twenty to twenty-six inches in dimension. 


\section{WANDERINGS IN SOU'TH AMERICA 299}

The large humming-bird, called by the Indians Karabimiti, invariably builds its nests in the slender branches of the trees which hang over the rivers and creeks. In appearance, it is like brown tanned leather, and without a particle of lining. The rim of the nest is double inwards, and I always conjectured that it had taken this shape on account of the body of the bird pressing against it while she was laying her eggs. But this is quite a wrong conjecture. Instinct has taught the bird to give it this shape, in order that the eggs may be prevented from rolling out.

The trees on the river's bank are particularly exposed to violent gusts of wind, and while I have been sitting in the canoe, and looking on, I have seen the slender branch of the tree which held the humming-bird's nest so violently shaken, that the bottom of the inside of the nest has appeared, and had there been nothing at the rim to stop the eggs, they must inevitably have been jerked into the water. I suspect the humming-bird never lays more than two eggs. I never found more than two in any of the many nests which have come in my way. The eggs were always white, without any spots on them.

Probably travellers have erred in asserting that the monkeys of South America throw sticks and fruit at their pursuers. I have had fine opportunities of narrowly watching the different species of monkeys which are found in the wilds, betwixt the Amazons and the Oroonoque. I entirely acquit them of acting on the offensive. When the monkeys are in the high trees over your head, the dead branches will now and then fall down 


\section{IVANDERINGS IN SOUTH AMERICA}

upon you, having been broken off as the monkeys pass along them; but they are never hurled from their hands.

Monkeys, commonly so called, both in the old and new continent, may be classed into three grand divisions: namely, the ape, which has no tail whatever; the baboon, which has only a short tail; and the monkey, which has a long tail. There are no apes, and no baboons, as yet discovered in the new world. Its monkeys may be very well and very briefly ranged under two heads: namely, those with hairy and bushy tails; and those whose tails are bare of hair underneath, about six inches from the extremity. Those with hairy and bushry tails climb just like the squirrel, and make no use of the tail to help them from branch to branch. Those who have the tail bare underneath towards the end, find it of infinite advantage to them, in their ascent and descent. They apply it to the branch of the tree, as though it were a supple finger, and frequently swing by it from the branch like the pendulum of a clock. It answers all the purposes of a fifth hand to the monkey, as naturalists have already observed.

The large red monkey of Demerara is not a baboon, though it goes by that name, having a long prensile tail. ${ }^{1}$ Nothing can sound more dreadful than its nocturnal howlings. While lying in your hammock in these gloomy and immeasurable wilds, you hear him howling at intervals, from eleven o'clock at night till daybreak. You would suppose that half the wild beasts of the

${ }^{1}$ I believe prensile is a new-coined word. I have seen it, but do not remember where. 


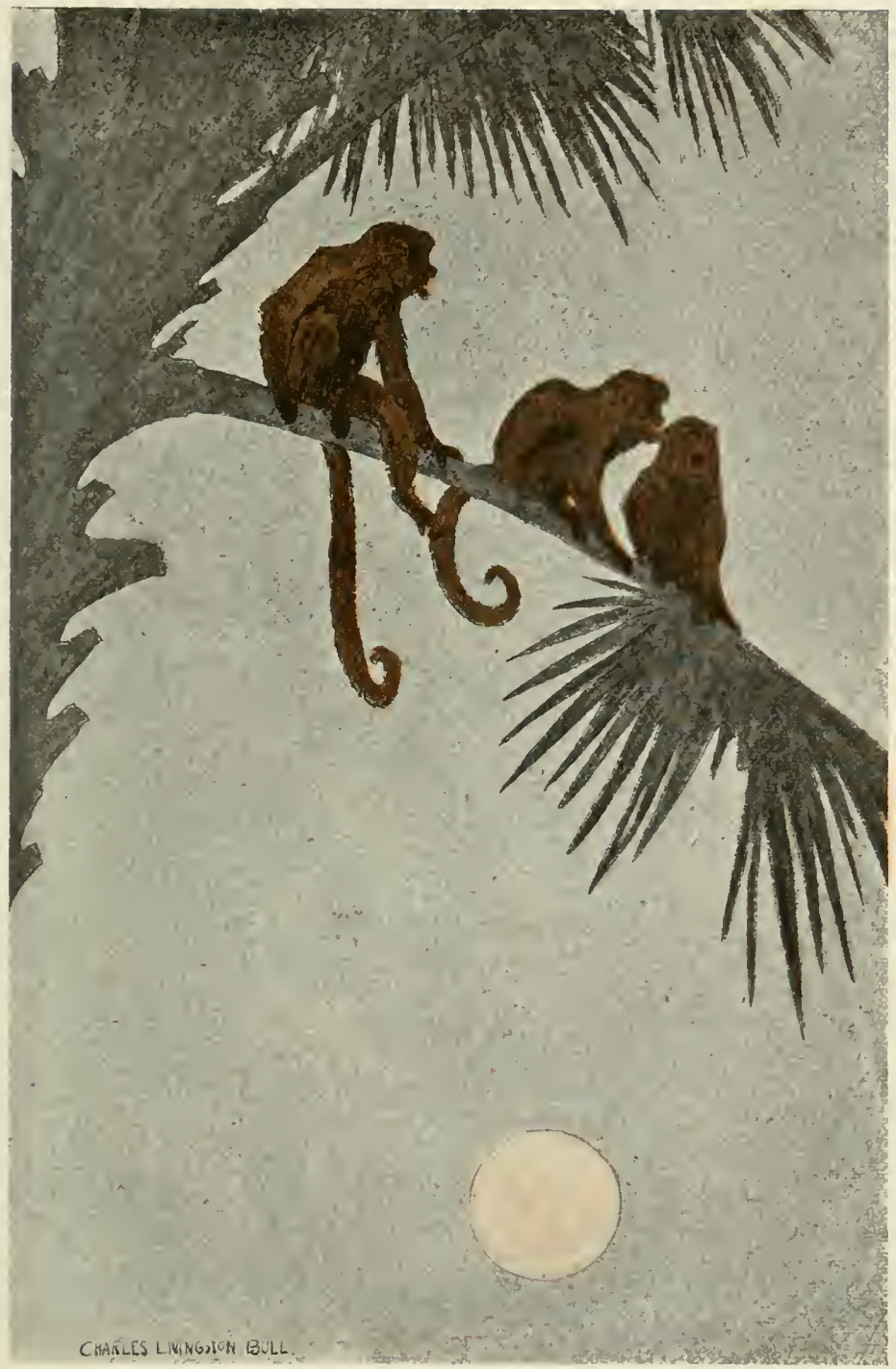

The Song of the Red Monkey 

forest were collecting for the work of carnage. Now, it is the tremendous roar of the jaguar, as he springs on his prey: now it changes to his terrible and deep-toned growlings as he is pressed on all sides by superior force; and now, you hear his last dying moan, beneath a mortal wound.

Some naturalists have supposed that these awful sounds, which you would fancy are those of enraged and dying wild beasts, proceed from a number of the red monkeys howling in concert. One of them alone is capable of producing all these sounds; and the anatomists, on an inspection of his trachea, will be fully satisfied that this is the case. When you look at him, as he is sitting on the branch of a tree, you will see a lump in his throat, the size of a large hen's egg. In dark and cloudy weather, and just before a squall of rain, this monkey will often howl in the daytime; and if you advance cautiously, and get under the high and tufted tree where he is sitting, you may have a capital opportunity of witnessing his wonderful powers of producing these dreadful and discordant sounds.

His flesh is good food; but when skinned, his appearance is so like that of a young one of our own species, that a delicate stomach might possibly revolt at the idea of putting a knife and fork into it. However, I can affirm, from experience, that after a long and dreary march through these remote forests, the flesh of this monkey is not to be sneezed at, when boiled in Cayenne pepper, or roasted on a stick over a good fire. A young one tastes not unlike a kid, and the old ones have somewhat the flavour of he-goat. 


\section{WANDERINGS IN SOUTH AMERICA}

I mentioned, in a former adventure, that I had hit upon an entirely new plan of making the skins of quadrupeds retain their exact form and feature. Intense application to the subject has since that period enabled me to shorten the process, and hit the character of an animal to a very great nicety, even to the preservation of the pouting lip, dimples, warts, and wrinkles on the face. I got a fine specimen of the howling monkey; and took some pains with it, in order to show the immense difference that exists betwixt the features of this monkey, and those of man.

I also procured an animal which has caused not a little speculation and astonishment. In my opinion, his thick coat of hair, and great length of tail, put his species out of all question; but then his face and head cause the inspector to pause for a moment, before he ventures to pronounce his opinion of the classification. He was a large animal, and as I was pressed for daylight, and moreover, felt no inclination to have the whole weight of his body upon my back, I contented myself with his head and shoulders, which I cut off: and have brought them with me to Europe. ${ }^{1}$ I have since found, that I acted quite right in doing so, having had enough to answer for the head alone, without saying anything of his hands and feet, and of his tail, which appendage, Lord Kames asserts, belongs to us.

The features of this animal are quite of the

1 My young friend, Mr. J. H. Foljambe, eldest son of Thomas Foljambe, Esq. of Wakefield, has made a drawing of the head and shoulders of this animal, and it is certainly a most correct and striking likeness of the original. 
Grecian cast; and he has a placidity of countenance which shows that things went well with him when in life. Some gentlemen of great skill and talent, on inspecting his head, were convinced that the whole series of its features has been changed. Others again have hesitated, and betrayed doubts, not being able to make up their minds, whether it be possible, that the brute features of the monkey can be changed into the noble countenance of man.-- "Scinditur vulgus." One might argue at considerable length on this novel subject; and perhaps, after all, produce little more than prolix pedantry. "Vox et præterea nihil."

Let us suppose for an instant, that it is a new species. Well ; "Una golondrina no hace verano ;" one swallow does not make summer, as Sancho Panza says. Still, for all that, it would be well worth while going out to search for it; and these times of Pasco-Peruvian enterprise are favourable to the undertaking. Perhaps, gentle reader, you would wish me to go in quest of another. I would beg leave respectfully to answer, that the way is dubious, long, and dreary; and though, unfortunately, I cannot allege the excuse of "me pia conjux detinet," still I would fain crave a little repose. I have already been a long while errant:- -

\footnotetext{
"Longa mihi exilia, et vastum maris æquor aravi, Ne mandate mihi, nam ego sum defessus agendo."
}

Should anybody be induced to go, great and innumerable are the discoveries yet to be made in those remote wilds; and should he succeed in 


\section{WANDERINGS IN SOUTH AMERICA}

bringing home, even a head alone, with features as perfect as those of that which I have brought, far from being envious of him, I should consider him a modern Alcides, fully entitled to register a thirteenth labour. Now if, on the other hand, we argue, that this head in question has had all its original features destroyed, and a set of new ones given to it, by what means has this hitherto unheard-of change been effected? Nobody in our museums has as yet been able to restore the natural features to stuffed animals; and he who has any doubts of this, let him take a living cat or dog, and compare them with a stuffed eat or dog in any of the first-rate museums. A momentary glance of the eye would soon settle his doubts on this head.

If I have succeeded in effacing the features of a brute, and putting those of a man in their place, we might be entitled to say, that the sun of Proteus has risen to our museums:-

"Unius hic faciem, facies transformat in omnes;

Nunc homo, nune tigris; nure equa, nune mulier."

If I have effected this, we can now give to one side of the skin of a man's face the appearance of eighty years, and to the other side that of blooming seventeen. We could make the forehead and eyes serene in youthful beanty, and shape the mouth and jaws to the features of a malicious old ape. Here is a new field opened to the adventurous and experimental naturalist: I have trodden it up and down till I am almost weary. To get at it myself I have groped through an 
alley, which may be styled, in the words of Ovid,"Arduus, obliquus, caligine densus opaca."

I pray thee, gentle reader, let me out a while. Time passes on apace; and I want to take thee to have a peep at the spots where mines are supposed to exist in Guiana. As the story of this singular head has, probably, not been made out to thy satisfaction, perhaps (I may say it nearly in Corporal 'Trim's words), on some long and dismal winter's evening, but not now, I may tell thee more about it; together with that of another head, which is equally striking.

It is commonly reported, and I think there is no reason to doubt the fact, that when Demerara and Essequibo were under the Dutch flag, there were mines of gold and silver opened near to the river Essequibo. The miners were not successful in their undertaking, and it is generally conjectured that their failure proceeded from inexperience.

Now, when you ascend the Essequibo, some hundred miles above the place where these mines are said to be found, you get into a high, rocky, and mountainous country. Here many of the mountains have a very barren aspect, producing only a few stinted shrubs, and here and there a tuft of coarse grass. I could not learn that they had ever been explored, and at this day their mineralogy is totally unknown to us. The Indians are so thinly scattered in this part of the country, that there would be no impropriety in calling it uninhabited:-

"Apparent rari errantes in gurgite vasto." 


\section{WANDERINGS IN SOUTH AMERICA}

It remains to be yet learnt, whether this portion of Guiana be worth looking after, with respect to its supposed mines. The mining speculations at present are flowing down another channel. The rage in England for working the mines of other states has now risen to such a pitch, that it would require a considerable degree of caution in a mere wanderer of the woods, in stepping forward to say anything that might tend to raise or depress the spirits of the speculators.

A question or two, however, might be asked. When the revolted colonies shall have repaired in some measure the ravages of war, and settled their own political economy upon a firm foundation, will they quietly submit to see foreigners carrying away those treasures which are absolutely part of their own soil, and which necessity (necessity has no law) forced them to barter away in their hour of need? Now, if it should so happen that the masters of the country begin to repent of their bargain, and become envious of the riches which foreigners carry off, many a teasing law might be made, and many a vexatious enaction might be put in force, that would, in all probability, bring the speculators into trouble and disappointment.

Besides this consideration, there is another circumstance which ought not to be overlooked. I allude to the change of masters nearly throughout the whole of America. It is a curious subject for the European philosopher to moralize upon, and for the politician to examine. The more they consider it, the more they will be astonished. If we may judge by what has already taken place, 
we are entitled to predict, that in a very few years more, no European banner will be seen to float in any part of the new world. Let us take a cursory view of it.

England some years ago possessed a large portion of the present United States. France had Louisiana; Spain held the Floridas, Mexico, Darien, Terra Firma, Buenos Ayres, Paraguay, Chili, Peru, and California; and Portugal ruled the whole of Brazil. All these immense regions are now independent states. England, to be sure, still has Canada, Nova Scotia, and a few creeks on the coast of Labrador; also a small settlement in Honduras, and the wilds of Demerara and Essequibo; and these are all. France has not a foot of ground except the forests of Cayenne. Portugal has lost every province; Spain is blockaded in nearly her last citadel; and the Dutch flag is only seen in Surinam. Nothing more now remains to Europe of this immense continent, where, but a very few years ago, she reigned triumphant.

With regard to the West India Islands, they may be considered as the mere outposts of this mammoth domain. St. Domingo has already shaken off her old masters, and become a star of observation to the rest of the sable brethren. The anti-slavery associations of England, full of benevolence and activity, have opened a tremendous battery upon the last remaining forts, which the lords of the old continent still hold in the new world; and, in all probability, will not cease firing till they shall have caused the last flag to be struck, of Europe's late mighty empire in the 


\section{WANDERINGS IN SOUTH AMERICA}

Transatlantic regions. It cannot well be doubted, but that the sable hordes in the West Indies will like to follow good example, whenever they shall have it in their power to do so.

Now with St. Domingo as an example before them, how long will it be before they try to raise themselves into independent states? And if they should succeed in crushing us in these our last remaining tenements, I would bet ten to one that none of the new governments will put on mourning for our departure out of the new world. We must well remember, that our own government was taxed with injustice and oppression by the United States during their great struggle; and the British press for years past has, and is still teeming with every kind of abuse and unbecoming satire against Spain and Portugal for their conduct towards the now revolted colonies.

France also comes in for her share of obloquy. Now, this being the case, will not America at large wish most devoutly for the day to come when Europe shall have no more dominion over her? Will she not say to us, our new forms of government are very different from your old ones. We will trade with you, but we shall always be very suspicious of you as long as you retain possession of the West Indies, which are, as we may say, close to our door-steads. You must be very cautious how you interfere in our politics; for, if we find you meddling with them, and by that means cause us to come to loggerheads, we shall be obliged to send you back to your own homes, three or four thousand miles across the Atlantic; and then, with that great 
ditch betwixt us, we may hope we shall be good friends. He who casts his eye on the East Indies, will there see quite a different state of things. The conquered districts have merely changed one European master for another; and I believe there is no instance of any portion of the Fast Indies throwing off the yoke of the Europeans and establishing a government of their own.

Ye who are versed in politics, and study the rise and fall of empires, and know what is good for civilized man, and what is bad for him, or in other words, what will make him happy and what will make him miserable-tell us how comes it that Europe has lost almost her last acre in the boundless expanse of territory which she so lately possessed in the west, and still contrives to hold her vast property in the extensive regions of the east?

But whither am I going? I find myself on a new and dangerous path. Pardon, gentle reader, this sudden deviation. Methinks I hear thee saying to me,-

"Tramite quo tendis, majoraque viribus audes."

I grant that I have erred, but I will do so no more. In general I avoid politics; they are too heavy for me, and I am aware that they have caused the fall of many a strong and able man; they require the shoulders of Atlas to support their weight.

When I was in the rocky mountains of Macoushia, in the month of June, 1812, I saw four young Cocks of the Rock in an Indian's hut; they 


\section{WANDERINGS IN SOUTH AMERICA}

had been taken out of the nest that week. They were of a uniform dirty brown colour, and by the position of the young feathers upon the head, you might see that there would be a crest there when the bird arrived at maturity. By seeing young ones in the month of June, I immediately concluded that the old cock of the rock would be in fine plumage from the end of November to the beginning of May: and that the naturalist, who was in quest of specimens for his museum, ought to arrange his plans in such a manner as to be able to get into Macoushia during these months. However, I find now, that no exact period can be fixed; for, in December, 1824, an Indian, in the river Demerara, gave me a young cock of the rock not a month old, and it had just been brought from the Macoushi country. By having a young specimen at this time of the year, it puts it out of one's power to say at what precise time the old birds are in full plumage. I took it on board a ship with me for England, but it was so very susceptible of cold that it shivered and died, three days after we had passed Antigua.

If ever there should be a great demand for large supplies of gum-elastic, commonly called India-rubber, it may be procured in abundance far away in the wilds of Demerara and Essequibo.

Some years ago, when I was in the Macoushi country there was a capital trick played upon me about India-rubber. It is almost too good to be left out of these Wanderings, and it shows that the wild and uneducated Indian is not without abilities. Weary and sick, and feeble through loss of blood, I arrived at some Indian huts, which 
were about two hours distant from the place where the gum-elastic trees grew. After a day and a night's rest $I$ went to them, and with my own hands made a fine ball of pure India-rubber; it hardened immediately it became exposed to the air, and its elasticity was almost incredible.

While procuring it, exposure to the rain, which fell in torrents, brought on a return of inflammation in the stomach, and I was obliged to have recourse again to the lancet, and to use it with an unsparing hand. I wanted another ball, but was not in a state the next morning to proceed to the trees. A fine interesting young Indian observing my eagerness to have it, tendered his services, and asked me two handsful of fish-hooks for his trouble.

Off he went, and to my great surprise returned in a very short time. Bearing in mind the trouble and time it had cost me to make a ball, I could account for this Indian's expedition in no other way except that, being an inhabitant of the forest, he knew how to go about his work in a much shorter way than I did. His ball, to be sure, had very little elasticity in it. I tried it repeatedly, but it never rebounded a yard high. The young Indian watched me with great gravity, and when I made him understand that I expected the ball would dance better, he called another Indian, who knew a little English, to assure me that I might be quite easy on that score. The young rogue, in order to render me a complete dupe, brought the new moon to his aid. He gave me to understand that the ball was like the little moon, which he pointed to, and by the time it grew big and old, 


\section{WANDERINGS IN SOUTH AMERICA}

the ball would bounce beautifully. This satisfied me, and I gave him the fish-hooks, which he received without the least change of countenance.

I bounced the ball repeatedly for two months after, but I found that it still remained in its infancy. At last I suspected that the savage (to ase a vulgar phrase) had come Yorkshire over me; and so I determined to find out how he had managed to take me in. I cut the ball in two, and then saw what a taught trick he had played me. It seems he had chewed some leaves into a lump, the size of a walnut, and then dipped them in the liquid gum-elastic. It immediately received a coat about as thick as a sixpence. He then rolled some more leaves round it, and gave it another coat. He seems to have continued this process till he made the ball considerably larger than the one I had procured; and in order to put his roguery out of all chance of detection, he made the last and outer coat thicker than a dollar. This Indian would, no doubt, have thriven well in some of our great towns.

Finding that the rainy season was coming on, I left the wilds of Demerara and Essequibo with regret, towards the close of December, 1824; and reached once more the shores of England, after a long and unpleasant passage.

Ere we part, kind reader, I could wish to draw a little of thy attention to the instructions which are to be found at the end of this book. Twenty years have now rolled away since I first began to examine the specimens of zoölogy in our museums. As the system of preparation is founded in error, nothing but deformity, distortion, and dispro- 
portion, will be the result of the best intentions and utmost exertions of the workman. Canova's education, taste, and genius enabled him to present to the world statues so correct and beautiful that they are worthy of universal admiration. Had a common stonecutter tried his hand upon the block out of which these statues were sculptured, what a lamentable want of symmetry and fine countenance there would have been. Now, when we reflect that the preserved specimens in our museums and private collections are always done upon a wrong principle, and generally by low and illiterate people, whose daily bread depends upon the shortness of time in which they can get through their work, and whose opposition to the true way of preparing specimens can only be surpassed by their obstinacy in adhering to the old method; can we any longer wonder at their want of success; or hope to see a single specimen produced that will be worth looking at? With this I conclude, hoping that thou hast received some information, and occasionally had a smile upon thy countenance, while perusing these "Wanderings;" and begging, at the same time, to add that

Well I know thy penetration

Many a stain and blot will see,

In the languid, long narration,

Of my sylvan errantry.

For the pen too oft was weary

In the wandering writer's hand,

As he roved through deep and dreary

Forests, in a distant land. 
Show thy merey, gentle reader, Let him not entreat in vain;

It will be his strength's best feeder, Should he ever go again.

And who knows how soon, complaining Of a cold and wifeless home, He may leave it, and again in Equatorial regions roam?

C. W. 


\section{ON PRESERVING BIRDS FOR CABINETS}

\section{OF NATURAL HISTORY}

Were you to pay as much attention to birds as the sculptor does to the human frame, you would immediately see, on entering a museum, that the specimens are not well done.

This remark will not be thought severe when you reflect that that which once was a bird has probably been stretched, stuffed, stiffened, and wired by the hand of a common clown. Consider likewise how the plumage must have been disordered by too much stretching or drying, and perhaps sullied, or at least deranged, by the pressure of a coarse and heavy hand-plumage which, ere life had fled from within it, was accustomed to be touched by nothing rougher than the dew of heaven, and the pure and gentle breath of air.

In dissecting, three things are necessary to ensure success, viz., a penknife, a hand not coarse or clumsy, and practice. The first will furnish you with the means; the second will enable you to dissect; and the third cause you to dissect well. These may be called the mere mechanical requisites.

In stuffing, you require cotton, a needle and thread, a little stick the size of a common knittingneedle, glass eyes, a solution of corrosive sublimate, and any kind of a common temporary box 


\section{WANDERINGS IN SOUTH AMERICA}

to hold the specimen. These also may go under the same denomination as the former. But if you wish to excel in the art, if you wish to be in orn1thology what Angelo was in sculpture, you must apply to profound study and your own genius to assist you. And these may be called the scientific requisites.

You must have a complete knowledge of ornithological anatomy. You must pay close attention to the form and attitude of the bird, and know exactly the proportion each curve, or extension, or contraction, or expansion of any particular part bears to the rest of the body. In a word, you must possess Promethean boldness, and bring down fire and animation, as it were, into your preserved specimen.

Repair to the baunts of birds on plains and mountains, forests, swamps, and lakes, and give up your time to examine the economy of the different orders of birds.

Then you will place your eagle in attitude commanding, the same as Nelson stood in, in the day of battle, on the Victory's quarter-deck. Your pie will seem crafty, and just ready to take flight, as though fearful of being surprised in some mischievous plunder. Your sparrow will retain its wonted pertness by means of placing his tail a little elevated, and giving a moderate arch to the neck. Your vulture will show his sluggish habits by having his body nearly parallel to the earth, his wings somewhat drooping, and their extremities under the tail instead of above it-expressive of ignoble indolence.

Your dove will be in artless, fearless innocence; 
looking mildly at you, with its neck, not too much stretched, as if uneasy in its situation; or drawn too close into the shonlders, like one wishing to avoid a discovery; but in moderate, perpendicular length, supporting the head horizontally, which will set off the breast to the best advantage. And the breast ought to be conspicuous, and have this attention paid to it; for when a young lady is sweet and gentle in her manners, kind and affable to those around her; when her eyes stand in tears of pity for the woes of others, and she puts a small portion of what Providence has blessed her with into the hand of imploring poverty and hunger-then we say she has the breast of a turtle-dove.

You will observe how beautifully the feathers of a bird are arranged, one falling over the other in nicest order; and that, where this charming harmony is interrupted, the defect, though not noticed by an ordinary spectator, will appear immediately to the eye of a naturalist. Thus, a bird not wounded and in perfect feather must be procured if possible, for the loss of feathers can seldom be made good; and where the deficiency is great, all the skill of the artist will avail him little in his attempt to conceal the defect, because, in order to hide it, he must contract the skin, bring down the upper feathers, and shove in the lower ones, which would throw all the surrounding parts into contortion.

You will also observe that the whole of the skin does not produce feathers, and that it is very tender where the feathers do not grow. The bare parts are admirably formed for expansion about 


\section{WANDERINGS IN SOUTH AMERICA}

the throat and stomach, and they fit into the different cavities of the body at the wings, shoulders, rump, and thighs with wonderful exactness; so that in stuffing the bird, if you make an even rotund surface of the skin where these cavities existed, in lieu of reforming them, all symmetry, order, and proportion are lost forever.

You must lay it down as an absolute rule that the bird is to be entirely skinned, otherwise you can never succeed in forming a true and pleasing specimen.

You will allow this to be just, after reflecting a moment on the nature of the fleshy parts and tendons, which are often left in: 1 st, they require to be well seasoned with aromatic spices; 2 dly, they must be put into an oven to dry; 3dly, the heat of the fire and the natural tendency all cured flesh has to shrink and become hard renders the specimen withered, distorted, and too small; 4thly, the inside then becomes like a ham or any other dried meat. Ere long the insects claim it as their own; the feathers begin to drop off, and you have the hideous spectacle of death in ragged plumage.

Wire is of no manner of use, but, on the contrary, a great nuisance; for where it is introduced, a disagreeable stiffness and derangement of symmetry follow.

The head and neck can be placed in any attitude, the body supported, the wings closed, extended or elevated, the tail depressed, raised or expanded, the thighs set horizontal or oblique, without any aid from wire. Cotton will effect all this.

A very small proportion of the skull bone, say, 
from the forepart of the eyes to the bill, is to be left in; though even this is not absolutely necessary. Part of the wing-bones, the jaw-bones, and half of the thigh-bones, remain. Everything else, flesh, fat, eyes, bones, brains, and tendons are all to be taken away.

While dissecting, it will be of use to keep in mind,-That, in taking off the skin from the body, by means of your fingers and a little knife, you must try to shove it, in lieu of pulling it, lest you stretch it.

That, you must press as lightly as possible on the bird, and every now and then take a view of it, to see that the feathers, \&c., are all right.

That, when you come to the head, you must take care that the body of the skin rests on your knee; for if you allow it to dangle from your hand, its own weight will stretch it too much.

That, throughout the whole operation, as fast as you detach the skin from the body, you must put cotton immediately betwixt the body and it; and this will effectually prevent any fat, blood, or moisture from coming in contact with the plumage. Here it may be observed that, on the belly you find an inner skin, which keeps the bowels in their place. By a nice operation with the knife, you can cut through the outer skin, and leave the inner skin whole. Attention to this will render your work very clean; so that, with a little care in other parts, you may skin a bird without even soiling your finger ends.

As you can seldom get a bird without shooting it, a line or two on this head will be necessary. If the bird be still alive, press it hard with your 
finger and thumb, just behind the wings, and it will soon expire. Carry it by the legs, and then, the body being reversed, the blood cannot escape down the plumage through the shot-holes. As blood will often have issued out before you have laid hold of the bird, find out the shot-holes, by dividing the feathers with your fingers, and blowing on them, and then, with your penknife, or the leaf of a tree, carefully remove the clotted blood, and put a little cotton on the hole. If, after all, the plumage has not escaped the marks of blood; or if it has imbibed slime from the ground, wash the part in water, without soap, and keep gently agitating the feathers, with your fingers, till they are quite dry. Were you to wash them, and leave them to dry by themselves, they would have a very mean and shrivelled appearance.

In the act of skinning a bird, you must either have it upon a table, or upon your knee. Probably, you will prefer your knee; because when you cross one knee over the other, and have the bird upon the uppermost, you can raise it to your eye, or lower it, at pleasure, by means of the foot on the ground, and then your knee will always move in unison with your body, by which much stooping will be avoided and lassitude prevented.

With these precautionary hints in mind, we will now proceed to dissect a bird. Suppose we take a hawk. The little birds will thank us, with a song for his death, for he has oppressed them sorely; and in size he is just the thing. His skin is also pretty tough, and the feathers adhere to it.

We will put close by us a little bottle of the solution of corrosive sublimate in alcohol; also a 
stick like a common knitting-needle, and a handful or two of cotton. Now fill the mouth and nostrils of the bird with cotton, and place it upon your knee on its back, with its head pointing to your left shoulder. Take hold of the knife with your two first fingers and thumb, the edge upwards. You must not keep the point of the knife perpendieular to the body of the bird; because, were you to hold it so, you would cut the inner skin of the belly, and thus let the bowels ont. To avoid this, let your knife be parallel to the body, and then you will divide the outer skin with great ease.

Begin on the belly below the breast-bone, and cut down the middle, quite to the vent. This done, put the bird in any convenient position, and separate the skin from the body, till you get at the middle joint of the thigh. Cut it through, and do nothing more there at present, except introducing cotton all the way on that side, from the vent to the breast-bone. Do exactly the same on the opposite side.

Now place the bird perpendicular, its breast resting on your knee, with its back towards you. Separate the skin from the body on each side at the vent, and never mind at present the part from the vent to the root of the tail. Bend the tail gently down to the back, and while your finger and thumb are keeping down the detached parts of the skin on each side of the vent, cut quite across, and deep, till you see the back-bone, near the oil-gland at the root of the tail. Sever the back-bone at the joint, and then you have all the 
root of the tail, together with the oil-gland, dissected from the body. Apply plenty of cotton.

After this, seize the end of the back-bone with your finger and thumb: and now you can hold up the bird clear of your knee, and turn it round and round, as occasion requires. While you are holding it thus, contrive, with the help of your other hand and knife, by cutting and shoving, to get the skin pushed up till you come to where the wing joins on to the body.

Forget not to apply cotton; cut this joint through; do the same at the other wing, add cotton, and gently push the skin over the head; cut out the roots of the ears, which lie very deep in the head, and continue skimning till you reach the middle of the eye; cut the nictitating membrane quite through, otherwise you would tear the orbit of the eye; and after this. nothing difficult intervenes to prevent your arriving at the root of the bill.

When this is effected, cut away the body, leaving a little bit of skull, just as much as will reach to the fore-part of the eye; clean well the jawbones, fasten a little cotton at the end of your stick, dip it into the solution, and touch the skull and corresponding part of the skin, as you cannot well get to these places afterwards. From the time of pushing the skin over the head, you are supposed to have had the bird resting upon your knee; keep it there still, and with great caution and tenderness return the head through the inverted skin, and when you see the beak appearing, pull it very gently till the head comes out unruffled and unstained. 
You may now take the cotton out of the mouth; cut away all the remaining flesh at the palate, and whatever may have remained at the under jaw.

Here is now before you the skin, without loss of any feathers, and all the flesh, fat, and uncleaned bones out of it, except the middle joint of the wings, one bone of the thighs, and the fleshy root of the tail. The extreme point of the wing is very small, and has no flesh on it, comparatively speaking, so that it requires no attention, except touching it with the solution from the outside. Take all the flesh from the remaining joint of the wing, and tie a thread about four inches long to the end of it; touch all with the solution, and put the wing-bone back into its place. In baring this bone you must by no means pull the skin; you would tear it to pieces beyond all doubt, for the ends of the long feathers are attached to the bone itself; you must push off the skin with your thumb-nail and forefinger. Now skin the thigh quite to the knee; cut away all flesh and tendons, and leave the bone: form an artificial thigh round it with cotton; apply the solution, and draw back the skin over the artificial thigh: the same to the other thigh.

Lastly, proceed to the tail; take out the inside of the oil-gland, remove all the remaining flesh from the root, till you see the ends of the tailfeathers; give it the solution, and replace it. Now take out all the cotton which you have been putting into the body from time to time to preserve the feathers from grease and stains. Place the bird upon your knee on its back; tie together the two 


\section{WANDERINGS IN SOUTH AMERICA}

threads which you had fastened to the end of the wing-joints, leaving exactly the same space betwixt them as your knowledge in anatomy informs you existed there when the bird was entire; hold the skin open with your finger and thumb, and apply the solution to every part of the inside. Neglect the head and neck at present; they are to receive it afterwards.

Fill the body moderately with cotton, lest the feathers on the belly should be injured whilst you are about the following operation. You must recollect that half of the thigh, or in other words, one joint of the thigh-bone, has been cut away. Now, as this bone never moved perpendicular to the body, but, on the contrary, in an oblique direction, of course, as soon as it is cut off, the remaining part of the thigh and leg, having nothing now to support them obliquely, must naturally fall to their perpendicular. Hence the reason why the legs appear considerably too long. To correct this, take your needle and thread, fasten the end round the bone inside, and then push the needle through the skin just opposite to it. Look on the outside, and after finding the needle amongst the feathers, tack up the thigh under the wing with several strong stitches. This will shorten the thigh, and render it quite capable of supporting the weight of the body without the help of wire. This done, take out every bit of cotton, except the artificial thighs, and adjust the wing-bones (which are connected by the thread) in the most even manner possible, so that one joint does not appear to lie lower than the other; for unless they are quite equal, the wings them- 
selves will be unequal when you come to put them in their proper attitude. Here then rests the shell of the poor hawk, ready to receive, from your skill and judgment, the size, the shape, the features and expression it had, ere death, and your dissecting hand, brought it to its present still and formless state. The cold hand of death stamps deep its mark upon the prostrate victim. When the heart ceases to beat, and the blood no longer courses through the veins, the features collapse, and the whole frame seems to shrink within itself. If then you have formed your idea of the real appearance of the bird from a dead specimen, you will be in error. With this in mind, and at the same time forming your specimen a trifle larger than life, to make up for what it will lose in drying, you will reproduce a bird that will please you.

It is now time to introduce the cotton for an artificial body, by means of a little stick like a knitting-needle; and without any other aid or substance than that of this little stick and cotton, your own genius must produce those swellings and cavities, that just proportion, that elegance and harmony of the whole, so much admired in animated nature, so little attended to in preserved specimens. After you have introduced the cotton, sew up the orifice you originally made in the belly, beginning at the vent. And from time to time, till you arrive at the last stitch, keep adding a little cotton, in order that there may be no deficiency there. Lastly, dip your stick into the solution, and put it down the throat three or four times, in order that every part may receive it. 


\section{WANDERINGS IN SOUTH AMERICA}

When the head and neck are filled with cotton quite to your liking, close the bill as in nature. A little bit of bees' wax, at the point of it, will keep the mandibles in their proper place. A needle must be stuck into the lower mandible perpendicularly. You will shortly see the use of it. Bring also the feet together by a pin, and then run a thread through the knees, by which you may draw them to each other, as near as you judge proper. Nothing now remains to be added but the eyes. With your little stick make a hollow in the cotton within the orbit, and introduce the glass eyes through the orbit. Adjust the orbit to them, as in nature, and that requires no other fastener.

Your close inspection of the eyes of animals will already have informed you, that the orbit is capable of receiving a much larger body than that part of the eye which appears within it when in life. So that, were you to proportion your eye to the size the orbit is capable of receiving, it would be far too large. Inattention to this has caused the eyes of every specimen, in the best cabinets of natural history, to be out of all proportion. To prevent this, contract the orbit, by means of a very small delicate needle and thread, at that part of it farthest from the beak. This may be done with such nicety, that the stitch cannot be observed; and thus you have the artificial eye in true proportion.

After this, touch the bill, orbits, feet, and former oil-gland at the root of the tail, with the solution, and then you have given to the hawk everything necessary, except attitude, and a 
proper degree of elasticity, two qualities very essential.

Procure any common ordinary box, fill one end of it, abont three-fourths up to the top, with cotton, forming a sloping plane. Make a moderate hollow in it to receive the bird. Now take the hawk in your hands, and, after putting the wings in order, place it in the cotton, with its legs in a sitting posture. The head will fall down. Never mind. Get a cork, and run three pins into the end, just like a three-legged stool. Place it under the bird's bill, and run the needle, which you formerly fixed there, into the head of the cork. This will support the bird's head admirably. If you wish to lengthen the neck, raise the cork, by putting more cotton under it. If the head is to be brought forward, bring the cork nearer to the end of the box. If it requires to be set backwards on the shoulders, move back the cork.

As in drying, the back-part of the neck will shrink more than the fore-part, and thus throw the beak higher than you wish it to be, putting yon in mind of a star-gazing horse, prevent this fault, by tying a thread to the beak, and fastening it to the end of the box with a pin or needle. If you choose to elevate the wings, do so, and support them with cotton; and should you wish to have them particularly high, apply a little stick under each wing, and fasten the end of them to the side of the box with a little bees' wax.

If you would have the tail expanded, reverse the order of the feathers, beginning from the two middle ones. When dry, replace them in their true order, and the tail will preserve for ever the 
expansion you have given it. Is the crest to be erect? move the feathers in a contrary direction to that in which they lie, for a day or two, and it will never fall down after.

Place the box anywhere in your room, out of the influence of the sun, wind, and fire; for the specimen must dry very slowly, if you wish to reproduce every feature. On this account the solution of corrosive sublimate is uncommonly serviceable; for at the same time that it totally prevents putrefaction, it renders the skin moist and flexible for many days. While the bird is drying, take it out and replace it in its position once every day. Then, if you see that any part begins to shrink into disproportion, you can easily remedy it.

The small covert feathers of the wings are apt to rise a little, because the skin will come in contact with the bone which remains in the wing. Pull gently the part that rises, with your finger and thumb, for a day or two. Press the feathers down. The skin will adhere no more to the bone, and they will cease to rise.

Every now and then touch and retouch all the different parts of the features, in order to render them distinct and visible, correcting at the same time any harshness, or unnatural risings or sinkings, flatness or rotundity. This is putting the last finishing hand to it.

In three or four days the feet lose their natural elasticity, and the knees begin to stiffen. When you observe this, it is time to give the legs any angle you wish, and arrange the toes for a standing position, or curve them to your finger. If you wish to set the bird on a branch, bore a little 
hole under each foot, a little way up the leg; and having fixed two proportional spikes on the branch, you can, in a moment, transfer the bird from your finger to it, and from it to your finger, at pleasure.

When the bird is quite dry, pull the thread out of the knees, take away the needle, \&c., from under the bill, and all is done. In lieu of being stiff with wires, the cotton will have given a considerable elasticity to every part of your bird; so that, when perching on your finger, if you press it down with the other hand, it will rise again. You need not fear that your hawk will alter, or its colours fade. The alcohol has introduced the sublimate into every part and pore of the skin, quite to the roots of the feathers. Its use is twofold. 1st. It has totally prevented all tendency to putrefaction; and thus a sound skin has attached itself to the roots of the feathers. You may take hold of a single one, and from it suspend five times the weight of the bird. You may jerk it; it will still adhere to the skin, and, after repeated trials, often break short. 2dly. As no part of the skin has escaped receiving particles of sublimate contained in the alcohol, there is not a spot exposed to the depredation of insects, for they will never venture to attack any substance which has received corrosive sublimate.

You are aware that corrosive sublimate is the most fatal poison to insects that is known. It is antiputrescent; so is alcohol; and they are both colourless; of course they cannot leave a stain behind them. The spirit penetrates the pores of the skin with wonderful velocity, deposits 
invisible particles of the sublimate, and flies off. The sublimate will not injure the skin, and nothing can detach it from the parts where the alcohol has left it. ${ }^{1}$

Furs of animals, immersed in this solution, will retain their pristine brightness and durability in any climate.

Take the finest curled feather from a lady's head, dip it in the solution, and shake it gently till it be dry; you will find that the spirit will fly off in a few minutes, not a curl in the feather will be injured, and the sublimate will preserve it from the depredation of the insect.

Perhaps it may be satisfactory to add here, that, some years ago, I did a bird upon this plan in Demerara. It remained there two years. It was then conveyed to England, where it stayed five months, and returned to Demerara. After being four years more there, it was conveyed back again through the West Indies to England, where it has now been near five years, unfaded and unchanged.

On reflecting that this bird has been twice in the temperate and torrid zone, and remained some years in the hot and humid climate of Demerara, only six degrees from the line, and where almost everything becomes a prey to the insect, and that it is still as sound and bright as when it was first done, it will not be thought extravagant to surmise

${ }^{1}$ All the feathers require to be touched with the solution, in order that they may be preserved from the depredation of the moth. The surest way of proceeding is, to immerse the bird in the solution of corrosive sublimate, and then dry it before you begin to dissect it. 
that this specimen will retain its pristine form and colours for years after the hand that stuffed it has mouldered into dust.

I have shown this art to the naturalists in Brazil, Cayenne, Demerara, Oroonoque, and Rome, and to the royal cabinets of Turin and Florence. A severe accident prevented me from communicating it to the cabinet of Paris, according to my promise. A word or two more, and then we will conclude.

A little time and experience will enable you to produce a finished specimen. "Mox similis volucri, mox vera volucris." If your early performance should not correspond with your expectations, do not let that cast you down. You cannot become an adept all at once. The poor hawk itself, which you have just been dissecting, waited to be fledged before it durst rise on expanded pinion; and had parental aid and frequent practice ere it could soar with safety and ease beyond the sight of man.

Little more remains to be added, except that what has been penned down with regard to birds may be applied, in some measure, to serpents, insects, and four-footed animals.

Should you find these instructions too tedious, let the wish to give you every information plead in their defence. They might have been shorter: but Horace says, by labouring to be brief you become obscure.

If, by their means, you should be enabled to procure specimens from foreign parts in better preservation than usual, so that the naturalist may have it in his power to give a more perfect 


\section{WANDERINGS IN SOU'TH AMERICA}

description of them than has hitherto been the case; should they cause any unknown species to be brought into public view, and thus add a little more to the page of natural history, it will please me much. But should they, unfortunately, tend to cause a wanton expense of life; should they tempt you to shoot the pretty songster warbling near your door, or destroy the mother, as she is sitting on the nest to warm her little ones; or kill the father, as he is bringing a mouthful of food for their support;-oh, then!-deep indeed will be the regret that I ever wrote them.

Adieu,

Charles Waterton. 


\section{INDEX}

A

Aborigines, 31.

Acaiari, 65, 203.

Accident to foot, 174.

Acouri, 49.

Teeth of, 84 .

Acoways, 201.

Acuero, 82.

Fta, 67, 68.

Ague, Tertian, 102.

Ai, 90.

Ai killed by Wourali, 91.

Albicore, 109.

Alligator, 67.

Anhingas, 163, 235.

Ants, 77, 184.

Coushie, 190.

Nests of, 69.

Ranger, 190.

Wood, 35.

Ant-bears, 35, 185, 194, 238.

Larg , 35 .

Small, 35.

Antidotes to Wourali, 93.

Antigua, 286.

A pourapoura, 57.

A pron, Indian, 203.

Ara humming-bird, 134.

Ara, Scarlet, 57, 70, 235, 297.

Aras, 58, 69, 108, 155.

Armadillo, 35, 192, 193.

Arowacks, 201.

Arrows, 86, 205.

Wourali, 82.

Arrowroot, 66.

\section{B}

BALSAM-CAPIVI, 64.

Banana, 188.

Banks, Sir Joseph, 175.

Barbadoes, 290.
Bats, 41.

Beetle, Rhinoceros, 288.

Bell-bird, 136.

Bête-rouge, 41, 64, 199.

Bill of Toucan, 138.

Birds of Demerara, 37, 132.

Bird-stuffing, 175,315 .

Bird-vine, 51.

Bisa, 35.

Bittern, 156.

Blackbirds, 120.

Blow-pipe, 59, 82.

Blue Heron, 156.

Boa Constrictor, 194.

Boat-bill, 156.

Boclora, 143.

Bois Immortelles, 133.

Bonito, 109.

Bouradi, 137.

Bows, 86, 205.

Broadway, 278.

Brown Monkey, 35.

Buffalo Town, 264.

Buletre, 50.

Bush-master, 39.

Bush-rope, 33, 34, 51.

\section{C}

CabBage-tree, 46.

Camoudi, 38 .

Camouni, R., 153.

Campanero, 40, 136, 231.

Canadians, 269.

Canoe, 67.

Caprimulgus, 57, 197.

Capture of Cayman, 242.

Caracara, 230.

Caribs, 201.

Cassava, Bitter, 202.

Sweet, 202.

Cassiques, 145. 
Castor oil, 173.

Castries, 289.

Cayenne, 124.

Cayman, 39, 196, 233, 240.

Back of, 247.

Capture of, 242.

Hook, 239.

Noise of, 233.

Teeth of, 247.

Chameleon, 40.

Chegoe, 200.

Cinnamon, 124, 126.

Climate of New York, 281.

Clove-tree, 124, 126.

Cocoa-nut, 118.

Cock of the Rock, 59, 127, 309.

Coffee-trees, 31.

Coot, 163.

Coral Snake, 39.

Corrosive sublimate, 320 .

Cotton, 46.

Cotingas, 108, 135.

Pompadour, 135.

Purple-breasted, 135.

Purple-throated, 135.

Scarlet, 134.

Couanacouchi, $39,78,81$.

Coucourite, 68, 70, 83.

Couguar, 237.

Coulacanara, 215, 222.

Courada-tree, 37.

Coushie Ant, 190.

Crab, 295.

Crabier, 37, 163.

Crabwood, 48.

Cranes, 163.

Crickets, 41.

Cuckoo, 289.

Cuia, 144.

Curial, 67.

Curlews, 163.

Curlew, Black, 68 .

Scarlet, 37, 68, 124, 163.

Custom-house duties, 251.

Cutlass or Machete, 34 .

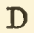

Daddi Quashi, 196.

Dara, 136.

Deer, 35, 68.

Demerara, 128.
Diamond Rock, 289.

Diet and raiment, 170.

Dissecting, Requisites for, 315 .

Divers, 106.

Dog, Experiment on with Wourali, 46.

In Guiana, 96.

Dolphin, 109.

Dominica, 287.

Ducalabali, 32.

Ducks, 163, 235.

Duck, Muscovy, 68, 156.

Duraquara, 160.

Duty on specimens, 252.

\section{E}

EAGLES, 162, 277.

Eagle, White-headed, 277.

Ebony, 32.

Edmonstone, Charles, 205.

Egret, 37, 68, 124, 156.

El Dorado, 73.

Emigrants, Irish, 271.

Escape from Spain, 16.

Essequibo, Falls of, 56, 248.

Eyes, False, 326.

\section{F}

Face of Countrt, 263.

Falcons, 162.

Falls, 47, 58 .

Essequibo, 56, 248.

False eyes, 326 .

Fever at Demerara, Yellow, 168.

Severe attack of, 171.

Fig, Wild, 33, 135, 152.

Finch, Red-headed, 118, 235.

Firefly, 42, 64 .

First Journey, 29.

Fish, 40.

Fish, Flying, 108.

Flamingo, 37, 123, 163.

Fly, 66 .

Sand, 41, 65.

Flying Fish, 108.

Forest on banks of Demerara, 30.

Fort St. Joachim, 72.

Fourth JOURNEY, 257. 
Fowls, Malay, 253.

Fox, 35.

Frigate Pelican, 110, 123.

Frogs, 41, 233, 288.

\section{G}

Gannets, 106.

Geese, 163.

George-town, 205.

Goat, 37.

Goatsuckers, 41, 156, 230, 233.

Gobe-mouche, 127.

Green-heart, 32, 50.

Grosbeak, scarlet, 294.

Guadaloupe, 287.

Guana, 35, 236.

Nest of, 236.

Guava, Wild, 135.

Gulls, 106, 110, 163.

\section{$\mathrm{H}$}

Habitations, Indian, 45.

Hackea, 32.

Haunaquoi, 41, 42, 161.

Hawks, 162, 224.

Hayawa, 32, 44, 57, 203.

Herons, Blue, 156.

Hia-hia Parrot, 154.

Hills, 56.

Hitia, 135.

Hoceo, 161.

Hog, Wild, 35, 46, 49.

Hook, Cayman, 239.

Horned Screamer, 161.

Hotels in New York, 280.

Houtou, 41, 59, 142.

Howler Monkey, 35, 41, 238, 300.

Humming-birds，37，108，132, $288,299$. Ara, 134.

Nests, 299.

Huts, Indian, 45.

\section{I}

IBIBIROU, 143.

India-rubber, 59, 310.
Indians, Acoway, 201.

Arowack, 201.

Carib, 201.

Macoushi, 58, 74, 201.

Warow, 201.

Religion of, 201.

Indian apron, 203.

Huts, 45.

Tribes, 201.

Insects, 40, 132.

Instructions to adventurers, 131.

Irish emigrants, 271.

\section{J}

JABIRU, 65, 66, 69, 163.

Jacamar, 150, 292.

Jaguar, 228, 233, 237, 241.

Jay, 143.

Jesuits in Pernambuco, 113.

JOURNEY, FIRST, 29.

SECOND, 106.

THIRD, 168.

FOURTH, 257.

Jumbo, 158.

K

KARABIMITI, 134, 299.

Kessi-kessi, 58, 70.

King, Savage, 62.

King Vulture, 37.

Kingfisher, 150.

$\mathrm{L}$

LABARRI, 39, 78, 81, 198.

Poison of, 199.

Labba, 35, 49.

Ladies, Ámerican, 265, 273, 278.

La Gabrielle, 125.

La Souffriere, 287.

Lemon trees, 118.

Letter-wood, 32.

Linnets, 118.

Lizards, 39.

Locust-tree, 32.

\section{M}

MAAM, 41, 49, 57, 161.

Macoushi Indians, 58, 74, 84. 
Manakins, 153.

Maou, R., 70.

Maribuntas, 197.

Marigalante, 287.

Maroudi, 41, 49, 84, 161.

White-crested, 64.

Martinico, 289.

Matatoro, 38.

Moca-moca, 147.

Monkeys, 205, 300.

Monkey, Brown, 35.

Flesh of, 301.

Red, 35, 41, 238, 300 .

Monteiro, 120.

Mora, 32, 33, 50, 63, 223, 230.

Moran, 64.

Mosquitos, 41, 64.

Mother Carey's chicken, 106.

Muscory Duck, 68, 156.

\section{$\mathrm{N}$}

NANDAPOA, 163.

Negroes, Runaway, 205.

New York, 278.

Climate of, 281.

Hotels, 280.

Streets of, 278.

Niagara, 264, 267.

Nondeseript, 302.

Nutmeg, 124, 126.

\section{$\mathrm{O}$}

ObJects OF WANDERINGS, 29.

Olou, 32.

Opossum, 35.

Orange trees, 118.

Otters, 40.

Ourah, 82.

Owl, 41, 43, 233, 295.

Ox killed by Wourali, 92.

\section{$\mathrm{P}$}

Pacou, 58, 229.

Palms, 118.

Papaw, 46, 202.

Paramaribo, 127.

Parima, 60, 68, 73 .

Paroquets, 41, 58, 70, 154, 222.

Parrots, 41, 154, 205, 235.

Parrot, Hia-hia, 154.
Partridge, 160.

Pataca, 41.

Peccari, 35.

Pee-ay-man, 204.

Pegalls, 205.

Pelican, 37, 163.

Frigate, 110, 123.

Pepper, 78, 124, 126, 202.

Pernambuco, 110.

Jesuits in, 113.

Port of, 111.

Petrel, Stormy, 106.

Phaeton, 123.

Philadelphia, 275.

Museum at, 275.

Piapoco, 137.

Pine-apples, 202.

Pi-pi-yo, 40, 214.

Pirai, 59, 83.

Pirarara, R., 70.

Pirrarri, 203.

Plantains, 202.

Plantations of Stabroek, 129.

Plover, 37, 163.

Spur-winged, 68.

Polecat, 35.

Poreupine, 36.

Potato, Sweet, 202.

Powises, 49, 84, 161.

Purple-breasted Cotinga, 135.

Purple-throated Cotinga, 135.

Purple-heart, 50, 67.

\section{Q}

QUADRUPEDS, 35.

Quail, 161.

Quake, 129.

Quebee, 271.

Quiver, 84.

\section{R}

RAILS, 163.

Raiment and diet, 170.

Rattlesnake, 38, 121.

Adventure with, 121.

Rapids of Essequibo, 56.

Ray, Sting, 235.

Recluse, White, 60.

Red-headed Finch, 118.

Red-headed Woodpecker, 173. 
Red Monkey, 35, 41, 238, 300.

Red Start, 287.

Remarks on First Journey, 99. Rhinoceros Beetle, 288.

Rice Bird, 145.

Roseau, 287.

Roucou, 203.

Runaway negroes, 205.

SABA, 31.

Sage, red, 133.

Saintes, 287.

Salempenta, 35.

Samourah, 82.

Sandflies, 41, 64.

Sandpiper, 37, 163.

Sangre do Buey, 118.

Saratoga, 272.

Savage King, 62.

Savanna, 63.

Sawari, 50, 188.

Searlet Ara, 57, 235. Curlews, 163.

Grosbeak, 294.

Scenery, 229, 259.

Scirou, 137.

Screamer, Horned, 161.

SECOND Journey, 106

Sharks, 110, 122.

Shrikes, 162.

Silk-grass, 82, 83, 202.

Siloabali, 50, 135.

Bastard, 135, 143.

Siparouni, 58.

Sir Joseph Banks, 175.

Slavery, 130, 290.

Sloth, 36, 176, 194, 293. Habits of, 176.

Killed by Wourali, 90.

Two-toed, 182.

Three-toed, 293.

Snakes, 38, 132, 198, 214

Snipes, 163.

Soil, 32.

Sounds, strange, 48.

Explanation of, 101.

Spikes for arrows, 87.

Spoonbill, 37, 124, 163.

Spur-winged Plover, 68.

Stabroek, 128.
Sting-ray, 235.

St. Joachim, Fort, 70, 72.

St. John's, Antigua, 286.

St. Lucie, 290.

Storm, 100.

Stormy Petrel, 106.

Strange sounds, 48.

Explanation of, 101.

St. Thomas's Tower, 101.

Stuffing, Bird, 175, 315.

Materials for, 315.

Sun-bird, 235, 295.

$\mathrm{T}$

TACATOU, R., 70.

Tangara, 119.

Tapir, 35, 46, 70.

Tauronira, 50, 51.

TAXIDERMY, 315.

Tertian ague, 102.

THIRD JOURNEY, 168.

Thrush, 42, 118.

Ticks, 201.

Ticonderoga, 272.

Tiger, 35, 37, 132, 232. Bird, 153.

Cats, 35.

Tinamous, 40, 49, 57 . Great, 296.

Small, 296.

Tirana, 235.

Tortoise, Land, 194, 232.

Toucan, 32, 69, 108, 137.

Bill of, 138.

Tribes, Indian, 201.

Troely, 42.

Tropic Bird, 110.

Troupials, 70, 118, 151.

Troy, 273.

Trumpeter, 161.

Turtle, Nest of, 235.

U

UNA-WAYA-ADOUCATI, 293

\section{V}

VAMPIRE, 38, 41, 188, 192, 297.

Teeth of, 298.

Vanilla, 196. 
Vines, 33.

Vine, Wourali, 77.

Vulture, Aura, 224.

Common, 37, 66, 162, 223.

Beak of, 223.

King, 37, 223.

\section{W}

WALLABA, 50, 51, 297.

Wallababa, 135.

Wanderings, Objects of, 29.

Waracaba, 49, 84, 161.

Warows, 201.

Wasps, 197.

Water-hen, Spur-winged, 156.

Watermamma, 61.

Wax, 82, 83.

Weeds, 34.

“'Whip-poor-Will,'” 43, 57, 158.

Whipsnake, 39.

White-headed Eagle, 277.

White Recluse, 60.

" Who-are-you,", 158, 230.

Wild beasts, 198 .

Hogs, 88, 211.

Man, 44.
"Willy-come-go,"' 43, 158, 230.

Wood Ants, 35.

Woodpeckers, 148.

Red-headed, 50, 173.

Woodskins, 67.

"Work-away," 158.

Wourali, 46, 58, 60, 69, 74, 90. Antidotes, 93.

Experiment on Ai, 90. Ass, 102.

Dog, 46.

Ox, 92.

Sloth, 90.

Preparation of, 77

Strength of, 46.

Vine, 77.

Wouralia, 103.

Wren, 42, 57, 118.

Y

ҮАВАНОU, 79, 158.

Yams, 202.

Yawaraciris, 153.

Yellow-fever at Demerara, 168. 


UNIVERSITY OF CALIFORNIA LIBRARY

Los Angeles

This book is DUE on the last date stamped below.

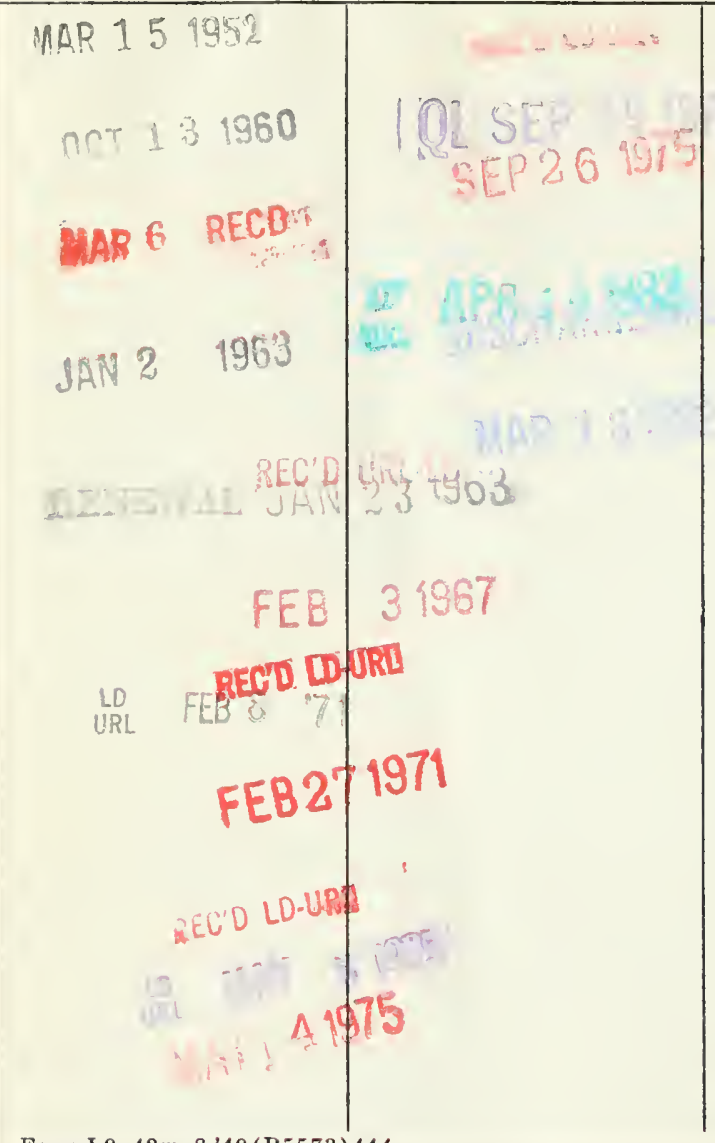

Form L9-42m-8,'49(B5573) 444

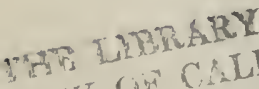

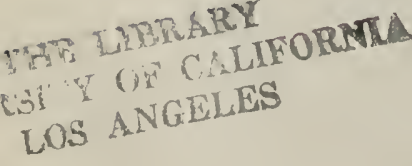




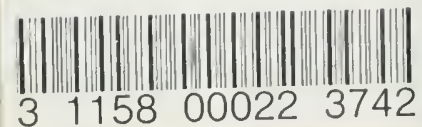

UC SOUTHERN REGIONAL LIBRARY FACILITY

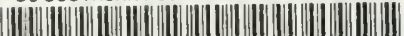

(a)

AA 0011628120 
